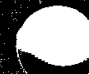

\title{
Legal and Institutional
}

\section{Impediments to}

Geothermal Energy

Resource Development

A Bibliography

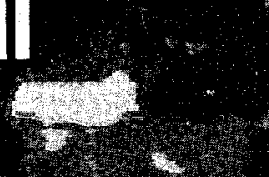




\section{DISCLAIMER}

This report was prepared as an account of work sponsored by an agency of the United States Government. Neither the United States Government nor any agency Thereof, nor any of their employees, makes any warranty, express or implied, or assumes any legal liability or responsibility for the accuracy, completeness, or usefulness of any information, apparatus, product, or process disclosed, or represents that its use would not infringe privately owned rights. Reference herein to any specific commercial product, process, or service by trade name, trademark, manufacturer, or otherwise does not necessarily constitute or imply its endorsement, recommendation, or favoring by the United States Government or any agency thereof. The views and opinions of authors expressed herein do not necessarily state or reflect those of the United States Government or any agency thereof. 


\section{DISCLAIMER}

Portions of this document may be illegible in electronic image products. Images are produced from the best available original document. 


\section{Legal and Institutional Impediments to Geothermal Energy Resource Development A Bibliography}

January 1978 


\section{Introduction}

This bibliography contains 485 references to literature on the subject of legal and institutional constraints to the development and use of geothermal energy resources. In addition to government-sponsored reports, journal articles, and books, the bibliography includes specific state and Federal laws and regulations, court cases of interest, and conference proceedings.

References are arranged in inverse chronological order and are made up of complete bibliographic citations. These are followed by an abstract or a listing of subject descriptors used to describe the subject content of each reference.

Four indexes are provided: Corporate, Personal Author, Subject, and Report Number. Each index is introduced by text that describes its content and format.

The citations in this bibliography are also included in DOE's Energy Data Base, and may be recalled using DOE's on-line computer retrieval system RECON. 


\section{CONTENTS}

abSTRACTS ....................... 1

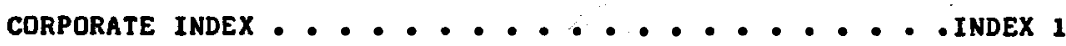

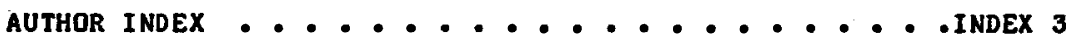

SUBJECT INDEX ................... INDEX 8

REPORT NUMBER INDEX ............... INDEX 45 


\section{ABSTRACTS}

1 INSTITUTIONAL AND ENUIRONMENTAL ASPECTS OF GEOTHERMAL ENERGY DEVELOPMENT. Citron, O.R. (Jet Propulsion Lab., Pasadena, CA). Nuc1. Technol.: 34: 38-42(Jun 1977).

The increasing interest in exploiting the variety of geothermal resources has prompted an examination of the institutional barriers to their introduction for comnerclal use. A significant effort was undertaken by the Jet Propulsion Laboratory as a part of a national study to identify existing constraints to geothermal development and possible remedial actions. These aspects included leglslative and legal paraneters plus environmental, social, and economic considerations.

2 GEOTHERMAL ENERGY DEVELOPMENT. Rowley, J.c. (University of Callfornla, Los Alamos, N. M.). Phys. Today: 30: No. 1, 36-45(Jan 1977 ).

Research needed to hasten the use of the 11 ttle-tapped but extensive heat energy of the Earth includes devising sensors to operate in the hot, corrosive underground environment and improving surface geophysical measurements.

3

COSTS OF GEOTHERMAL ENERGY DEVELOPMENT. FINAL REPORT, JANUARY 1977. Larson, T . Riverside, CA; Dry Lands Research Inst. (1977). $63 \mathrm{p}$.

Maln updated materlal from earlier July 1976 paper inciudes additional sources of cost information in the tables; portions concerning County Property Taxes; and RIsks and Returns on Investment. Both optimistic and pessimistic projections of capltal and operating costs necessary to develop and maintain a 200 MW geothermal fleld and power plant in Imperlal Valley for 20 to 30 years are examined. (PCS)

4 REGULATORY, PLANNING AND POLICY ASPECTS OF GEOTHERMAL ENERGY DEVELOPMENT IN IMPERIAL COUNTY, CALIFORNIA, BUCK, J.V.: GI Uck, D.; Hagman, D.: Krier, J.: Thompson, S. Riverside, CA; Dry Lands Research Inst. (1977). VP.

Political and legal aspects of varlous possible county regulations that could apply to geothermal development are revlewed. (PCS)

5

ECONOMIC IMPACT OF GEOTHERMAL ENERGY DEVELOPMENT. Rose, A. Riverside, CA; Dry Lands Research Inst. (1977). 103p.

While this investigation is basicaliy a case study for the Imperial Valley, meny of the results are applicable to geothermal development elsewhere and to development of other new energy sources, solar and tidal power, which all share common characteristics.
Thirteen major economic Indicators are analyzed for direct, secondary economic and demographic effects are given for the primary development scenarlo which calls for 4500 hW of electric generating capacity, in Imperial County by the year 2020. Impacts on agriculture; Income distribution; employment; occupational variety: fiscal Impact and potential costs for pollution abatement or control. A summary of policy recommendations are given for local control over each socio-economic variable. (PCS)

6 EFFECTS OF GEOTHERMAL DEVELOPMENT ON THE AGRICULTURAL RESOURCES DF THE IMPERIAL VALLEY. Johinson, C. Riverside, CA: Dry Lands Research Inst. (1977). 27p.

The agricultural resources are mapped for each of four KGRA's in the Imperial Valley. The maps show crops, land ownershlp, and Irrigation canals. It is concluded that no more than $3.36 \%$ of the land is needed for geothermal development and thet careful planning could reduce this figure to less than 1x. (MHR)

OPINION ABOUT GEOTHERMAL DEVELOPMENT IN IMPERIAL COUNTY, CALIFORNIA, 1976. FINAL REPORT. Butler, E.W.; Pick, JaB. Riverside, CA; Dry Lands Research Inst. (1977). 67p.

The results of a public opinion survey on geothermal development are presented. It was concluded that nine out of ten persons surveyed were in favor of it. There was clear agreement that geothermal development should be strictly regulated. However, only amall minority of the Imperial County population feels that they have very good understanding of geothermal development. The methodology. questlonnalre, and statistical results for each question are given. (MHR) POPULATION ANALYSIS RELATIVE TO GEOTHERMAL ENERGY DEVELOPMENT, IMPERIAL COUNTY, CALIFORNIA. Plck, J.B.; Jung, T.H.: Butler, E. Riverside, CA; Dry Lands Research Inst. (1977). 118p.

The following toplcs are covered: general demography, economic effects on migration, energy capacity and consumption, population and economic statistics for Imperial County, 1950-1970, reglonal socloeconomic comparisons, discriminant analysis of geothermal areas, Spanish American population of Imperial County. regional employment implications for geothermai energy development, population projectlons and transferability of methods and results. (MHR) GEOTHERMAL RESOURCES DEVELOPMENT INSTITUTE CONFERENCE, SALT LAKE CITY, UTAH, JANUARY 27-28,1977 . Boulder, CO; Rocky Mountain Mineral 
Law Foundation (1977). vp.

Fourteen papers and a bibllography are presented. Separate abstracts were prepered for each. (MHR)

10 INTRODUCTION AND LEGAL OVERVIEW OF GEOTHERMAL RESOURCES. Root, T.E. (Energy Fuels Corp., Denver). pp 6p, Paper 1 of Geothermal Resources Development Institute. Boulder, CO; Rocky Mountaln Mineral Law Foundation (1977).

From Conference on geothermal development;

Salt Lake City, UT, USA (27 Jan 1977).

A brief introduction to the papers to follow is presented. (MHR)

11 TECHNICAL OVERVIEN OF GEOTHERMAL RESOURCES. Austin, C.F. (Naval Heapons Center, China lake, CA). Pp 15p, Paper 2 of Geothermal Resources Development Institute. Boulder, CO; Rocky Mountain Mineral Law Foundation (1977).

From Conference on geothermal development; Salt Lake City, UT, USA (27 Jan 1977).

A geothermal deposit is defined as an accumulation of heat within the crust of the earth. Those geologic processes that first of all provide heat and nore specifically accunulate that heat into a locallzed and concentrated deposit are described. (MHR)

12 GEOTHERMAL LEASING PRACTICES. Kitchen, G.J. (AMAX, Inc., Denver). PP 38p, Paper 3 of Geothermal Resources Development Institute. Boulder, CO; Rocky Mountain Mineral Law Foundati on (1977).

From Conference on geothermal development; Salt Lake City, UT, USA ( 27 Jan 1977). A general overview of the resource is presented to the extent the subject bears on leasing practices. Some legal and practical problems involved in developing the resource are discussed. Finally, a hypothetical land situation is described and some suggestions are made for leasing geothermal resources on the described prewl ses. (MHR)

13 GEDTHERMAL RESOURCES JOINT VENTURES. Schlauch, P.J. (Dawson, Nagel, Sherman, and Howard, Denver). PP 23p, Paper 4 of Geothermal Resources Development Insti tute. Boulder, CO; Rocky Mountain Mineral Law Foundation (1977).

From Conference on geothermal development: Salt Lake City, UT, USA (27 Jan 1977).

An at tempt is made to Identify and analyze the more important of the differences betreen joint ventures in ofl and gas and those in geothermal resources. Matters which should recelve special attention in structuring a geothermal resource foint venture are dI scussed. (MHR)

14 ROLE OF MUNICIPALITIES IN GEOTHERMAL RESOURCE DEVELDPMENT: Kraner, H.K.; Hatmer, M. (O'Melveny and Meyers, Los Angeles). PP 29p, Paper 5 of Geothermal Resources Development Institute. Boulder; CO; Rocky Mountain Mineral Law foundation (1977).

Fró Conference on geothermal development; Salt Lake C1ty, UT, USA ( 27 Jan 1977). Those provisions of Californl law affecting aunicipal utilities interest in geothermal exploration, development, and exploitation are explored. The varlous problems encountered by the Clty of Burbank and the Northern Callfornia Power Agency are used as lllustrations. The Impact of self-imposed 1 initations in the form of outstanding bond covenants and other contractual obligations are considered. (MHR)

15 GEOTHERMAL RESOURCES: WATER AND OTHER CONFLICTS ENCOUNTERED BY THE DEVELOPER. AN ALTERNATIVE ENERGY SOURCE WHICH IS - GATHERING STEAM" ". Vranesh, G.: Musick, J.D. Jr. (Vranesh and Muslck, Boulder, $C D$ ). Pp 66p, Paper 6 of Geothermal Resources Development Institute. Boulder, CO; Rocky Mountein

Mineral Law Foundation (1977).

From Conference on geothermal development; Salt Lake City, UT, USA (27 Jan 1977). Geothermal resources are described briefly. Varlous environmental, legal, and technlcal obstacles are reviewed. Federal and state legislation and case law are outlined which wight affect geothermal development if the resource is treated as elther mineral or water. The treatment of geothermal resources in one jurisdiction, Colorado, is summarized, and possible legal solutions necessary to meet a goal of fuel sufficlency which is prudently accountable both environmentally and technologlcally are summarlzed. (MHR)

16 WATER CONFLICTS FROM THE VIEWPOINT OF A REgUlatoR. Hansen, D.C. pp 9p, Paper 7 of Geothermal Resources Development Institute. Boulder, CO: Rocky Mountain Mineral Law Foundation (1977).

From Conference on geotheraal development: Salt Lake City, UT, USA ( 27 Jan 1977).

Maps are given showing known geothermal resource areas and areas which are prospectively valuable in the western states. From the viem-polnt of a regulator the biggest hurdle for geothermal development to overcome is the large quantity of water that will be consumptively evaporated into the atmosphere in the generation of electricity. Current estimates for the amount of water consumed is $48 \mathrm{acre-reet/year/MW.} \mathrm{Water} \mathrm{rights} \mathrm{need} \mathrm{to} \mathrm{be}$ protected but on the other hand geothermal development cannot be based on a presumption of interference. (MHR)

17 UNITIZATION FOR GEOTHERMAL RESOURCES: UNITED WE SAVE. GoldsteIn, D.B. (Homestake Mining Co., San Francisco). PP 40 , Paper 8 of Geothermal Resources Development Institute. Boulder, CO; Rocky Mountaln Mineral Law Foundation (1977).

From Conference on geothermal development; Salt Lake City, UT, USA ( 27 Jan 1977). The following subjects are discussed: reservolr model, unitization applied to the geothermal model, maximizing total energy recovery through unitized operations, maximlizing the economic use of recovered geothermal energy, prevention of the drilling of unnecessary welis, the need for drilling units, protection of ' correlative rights'?, allocation of unit production, "'stand-by" wells, injection, rights-of-way, statutory law applicable to geothermal unitlzation in California, practical obstacles to voluntary unitization, and the need for compulsory geothermal unitization. (MHRR)

18 FEDERAL ROLE IN GEOTHERMAL RESOURCE DEVELOPMENT. Stephens, R.C. (Energy Research and Development Administration, Washington, DC). PP Ilp, Paper 9 of Geothermal Resources Development Instl tute. Boulder, CO; Rocky Mountain Mineral Law Foundati on (1977).

From Conference on geothermal devel opment:

Salt Lake C1ty, UT, USA (27 Jan 1977).

The components of the Federal program andated by PL 93-410 include specifically: 
(1) Resource Inventory and Assessment, (2) Research and Developnent, (3) Demonstration, (4) Sclentlfle and Technical Education, and (5) Loan Guarantles. Included in the goa is of the research and development effort were social, legal, and economlc studies for the development of policy conducive to commercial geothermal development. ERDA has taken the lead role in pollcy development. This aspect is discussed in some detall, following a brief description of the program areas. Areas covered Include: inst ltut lonal developaent, Federal land management. Federal taxation, the Geothermal Loan Guaranty Program, State and Local Government, and Federal Incentives. (MHR)

19 CONSTRAINTS ON GEOTHERMAL DEVELOPMENT: TAX AND BEYOND. MeNamara, J.J. (UnIV. of Southern Celifornia, Los Angeles). Pp 18p, Paper 10 of Geothermal Resources Development Institute. Boulder, CO: Rocky Mountaln Mineral Law Foundation (1977).

From Conference on geothermal development; Salt Lake City, UT, USA ( 27 Jan 1977).

Difficulties with tax policies, energy polfey, and various constrainta as they relate to energy, especially geothermal energy are reviewed. (MHR)

20 INCOME TAXATION OF GEOTHERMAL RESOURCES Maxfleld, P.C. (Unlv. of Wyoming, Laranle). pp 51p, Paper 12 of Geothermal Resources Development Institute. Boulder, CD; Rocky Mountain Mineral Law Foundation (1977).

From Conference on geothermal development; Salt Lake Clty, UT, USA ( 27 Jan 1977).

It is proposed to outline as precisely as possible the state of the law with regard to this resource. Because the rederal income tax laus relating to ineral exploration and development to great extent turn at least indirectiy on the specific depletion laws applicable to the varlous forms of geothermal energy, and the type of depletion allowable, i.e. statutory (percentage) and/or cost, it appears necessary to eschew hereln : transactlonal type of approach which would proceed rrom acqul sition to exploration, to development, to operation, to disposition in favor of the keystone questions, i.e. the allowability of depletion vel non and the type(s) of depletion allowable. These other subjects are examined primarily in so far as there are tax problens pecullar to the fledgling geothermal industry or in so far as there is uncertainty as to applicability of otherwlse settled law. (MHR)

21 GEOTHERMAL SALES CONTRACTS, Snyder, S.A. (Union Oil Co. of Callfornia, Los Angeles). pp 37p, Paper 13 of Geothermal Resources Development Institute. Boulder, CO; Rocky Mountain Minerel Law Foundation (2977).

From Conference on geothermal development; Salt Lake City, UT, USA (27 Jan 1977).

The sixteen sections in the flrst geothermal stean sales contract between Magma Power Company and Thermal Power Company and Pacific Gas and Electric Company are listed and discussed briefly. The legal developments between contracts are mentloned. A checkllst is given of matters that nust be considered in negotlating a sales contract for geothermal energy: restrictions contalned in seller's title, consideration of problems involving the lease term, the problem of "'other minerals'" produced with the geothermal fluids, water law, other lease clauses that must be considered in the negotiations of a sales contract, the royalty problem, conditions precedent to the effectiveness of a contract, rights comitted to the contract, taxes, price and measurement, equipment for conversion of the geothermal energy to electriclty, surface rights, effluent disposal, right to terminate, renegotiation on changed conditions, assignments, indernitles and Insurance, settlement of disputes, applicable law, and confidentiality. (KHR)

22 ENUIRONMENTAL DVERVIEH OF GEOTHERMAL RESQURCES DEVELOPMENT - Tarlock A.D.: Waller, R.L. (Indiana Univ., Bloomington, IN). PP 12p, Paper 14 of Geothermal Resources Development Insti tute. Boulder, CD; Rocky Mountain Mineral Law Foundation (1977).

From Conference on geothermal development: Salt Lake CIty, UT, USA ( 27 Jan 1977).

Geothermal exploration can be divided into the exploration, test drilling, production testing, fleld development, and power generation stages. The major expected physlcal adverse environmental Impacts which can be expected during each of these five major stages are discussed. Next, the regulations applicable to each of the four potential confllcts (land use, water, al $r$, and nolse) are surveyed. (MHR)

OVERVIEN OF THE CALIFORNIA PERMITTING PROCESS. Trower, E.D. (Western Law Dept., Denver). pp 27p, Paper 15 of Geothermal Resources Development Institute. Boulder, CO; Rocky Mountain Mineral Law Foundation (1977). From Conference on geothermal development: Salf Lake City, UT, USA (27 Jan 1977).

During the more than fifteen years that it has lived with geothermal power production, California has developed, and continues to develop, sophisticated geothermal regulatory structure. An overview is presented of that structure giving special emphasis to the exploration permitting process. The newly enacted Napa County Geothermal Ordinance is a focal point for discussion of the substantial powers which Callfornis has delegated to local units of state government. (MHR)

24 SUMMARY AND CONCLUDING REMARKS. OIPIn; 0 . (DiMelveny and Meyers, Los Angeles). PP 1 of Geothermal Resources Development

Institute. Boulder, CO; Rocky Mountein Mineral Law Foundation (1977).

From Conference on geothermal development Salt Lake Clty, UT, USA ( 27 Jan 1977).

A geothermal bibllography is presented that I. primarlily composed of legal items. (MHR)

251977 GUIDEBOOK TO CALIFORNIA TAXES UITH SPECIAL EMPHASIS DN RELATIONSHIP TO FEDERAL TAXES Bock, R,S. Chlcago; Commerce? Clearing House, Inc. (1977). 462p. \$7.00. This book is deslgned to be quick reference work on Callfornia state taxes. With this in aind, the amount of detall is kept to a minimum by assuming that the reader hes some knowledge of federal taxes that are generally similar to the major Callfornia taxes (or that he has access to the wealth of information about federal taxes that is readily available). The book explains the four ajor Callfornla taxes (personal income tax, tax on corporate income, Inheritance tax, and gift tax), whenever possible, In terms of the comparable Federal taxes. Differences between the two laws are pointed out, and crossreferences nake It possible to trace from a given.provision in one law to a comparable provision in the other. Special attention is given to subjects peculiar to the Callfornia law. In addition to the major state taxes, the book provides general information about 
other taxes levied by the State. Property taxes are al so discussed briefly, because of their statewide impact, al though they are imposed by local governmental units.

26 GEOTHERMAL RESOURCES OPERATIONAL ORDER NO. 6: PIPELINES AND SURFACE PRDDUCTION

FACILITIES. Washington, DC; Geologlcal Survey (1977). 7p.

This Order (effective January 1,1977 ) is estabilished pursuant to the authority preseribed in 30CFR270.11. The design, operatlon, and testing of all pipelines and surface facilities will be conducted in accordance with the provisions of this order. All variances 1 rom the requi rements specified In this Order, shall be subject to approval pursuant to 30CFR270.48. References in this Order to approvals, determinations, or requlrements are to those given or made by the Area Geothermal Supervisor or his delegated representative. The design of all plpelines and surface facilities, Including but not linited to, production, injection, and waste rater disposai systems, shall be submitted with the Appl lcation for Permit to Drill or on a Sundry Notice to the Supervisor for approval prior to construction. In addition, Plan of Operation with contents and approval according to 30CFR270.34, shall be required when surface of environmental disturbances are anticipated beyond those covered by a previously. approved Plan of Dperation. Guidelines for design and construction, applying for construction of pipelines and related surface facilities, and the completion report are given.

GEOTHERMAL RESOURCES OPERATIONAL ORDER NO. 7: PRODUCTION AND ROYALTY MEASUREMENT, EQUIPMENT, AND TESTING PROCEDURES. Washington, DC: Geological Survey (1977). 7p. This Order (effective Januray 1,1977 ) is established pursuant to the authority prescribed in 30 CFR270.11 and 270.12 and in accordance with 30CFR270.60, 270.64, 270.74, and 270.75 . All geothermal production and the resulting produced energy (electricity) or byproducts, and leasehold operational ut llization thereof, shall be measured and monitored in accordance with the provisions of this Order. All variances from the requirements specifled in this Order shall be subject to approval pursuant to $30 \mathrm{CF} 270.48$. References in this Order to approvals, determinations, or requil rements are to those given or made by the Area Geothermal Supervisor or his delegated representatives. Metering. commingling production, common storage, meter testing and maintenance, and application for meter Installation criteria are furnished.

28 MULTISECTOR ANALYSIS OF THE IMPACT OF GEOTHERMAL DEVELOPMENT ON THE ECONOMY DF IMPERIAL COUNTY, CALIFORNIA. Lofting, E.M. Riverside, CA; Dry Lands Research Inst. (1977). 78 .

An 85 sector input--output model for Imperial County was developed for 1972. model uas based on secondary date sources and modified national technical coefflcients using the SLQ technique. Type I and type II income, employment, and value added multipliers were developed for each sector. Projectlons of economic activity were made for the 1975--2020 period based on population projections which (I) assumed no geothermal development in the county and (III) a ssumed geothermal development and relatively rapid population growth.

Agricultural development was assumed to grow to 1.8 times its present level in both cases. For the Series I projection per capita income in 1972 constant dollars 111 remain essentially constant, thile in the Series III projection It is estimated to increase from $\$ 4500$ to $\$ 7100$ per year. In both cases the employment to population ratio can be expected to remain relatively constant. Geothermal development is projected to add $\$ 700$ million per year to the personal Income of Imperial County by the year 2020. The linear programming analysis reveals that achieving projected growth in agricultural output will require an improvement in water use efficiency of at least $35 \%$. When compared to alternative policles, such as attempting to maximize gross county product, employment maxialzing policies may not result in significant increases in employment.

29 GEOGRAPHICAL ENUIRONMENTAL ANALYSIS. FINAL REPORT. Pasqualetti, M.J. Riverside, CA: Dry Lands Research Inst. (1977). 177p. Interim conclusions concerning potential environmental impact from geothermal resource development in the Imperial Valley are made. Environmental effects from the initial phases of geothermal development will be mininal; however, no method of prediction can substitute for actual operation experience. Policy alternatives and recommendatlons for dealing with the environmental impact are discussed. (PCS)

30 GUIDELINES RELATIVE TO PIPELINES AND SURFACE PRODUCTION EQUIPMENT AND TO PRODUCTION AND ROYALTY MEASUREMENT, EQUIPMENT, AND TESTING PROCEDURES (ORDER NOS. 6 AND 7 ). Radlinski, W.A. Fed. Reglst. (Wash., D.C.): 41: No. 236, 53498-53499( 7 DeC 1976). (30CFR270).

These orders list significant modifications made in the draft orders (42 Fed. Reg. 100: 20901-02) providing guidelines relative to Pipelines and Surface Production Equipment and to Production and Royalty Measurement, Equipment and Testing Procedures for geothermal resources operations in the central and western regions. (PCS)

31 LEGAL ISSUES IN THE DEVELOPMENT OF GEOPRESSURED GEOTHERMAL RESOURCES OF TEXAS AND LOUISIANA GULF COAST (SUMMARY). Elmer, D.B. (Univ. of Texas, Austin). Geotherm. Energy Mag.: 4: No. 9, 13-19, 22-25, 27-28, 30-33, 3538(Sep 1976).

Two major toplcs, legal scholarship and legal support, are covered. Scholarship is distinguished from support by concentration on abstract analyses of issues, which include resource definition, ownership, taxation, and mult istate reservolrs. Support is based entirely on those legal tasks called up by the technical work scheduled in the areas of resource assessment, advanced research and technology, Institutlonal and environmental and resource utilization. The definitions contained in the statutes of the thirteen western states, Texas, and Loulslana are presented. (MHR) Dig. (Wash., D.C.); 6: No. 10, 597(20 Aug 1976 ).

The stresses and strains that would result from the nining of tossil and nuclear fuels on Indian reservations in the western U. S. cannot be conveyed in environmental impact statements, according to Ronald G. Falch, director of the Navajo Research and Stat istics Center at Window Rock, Arizona. There are 22 Indian tribes with valuable energy resources. In the U.S., Indian lands contaln more than half the known coal reserves on public domain and 33 percent of all 
proven reserves west of the Mississippl. More than three-fourths of the Navajo tribe's revenues do come from its energy leasing program. Indians currently have two geothermal, 13,583 petroleum, 380 urani um, and 11 coal leases. Some tribes desire to mine, refine, and sell their own resources. Federal agencles are helping with financial, technical, and legal guldance. (MCW)

33 HEARING ON THE OWNERSHIP OF GEOTHERMAL STEAM UNDERLYING GEYSERS. GEOTHERMAL KINETICS INC., PLAINTIFF, VS UNION OIL COMPANY OF CALIFORNIA, DEFENDANTS, MAY 28, 1976. Geyser; 3: No. 11, vp(12 Aug 1976).

The question before the court (Superior Court of the state of California) was whether the geothermal steam system belongs to the owner of the mineral rights or the surface rights. This case involved confilcting claims to the geothermal stean system which underlies 408 acres of essentlally unimproved mountain property lying south of Big sulfur Creek in an area known as 'The Geysers' I In Sonoma County, California. A history of the land and mineral rights transfers since 1925 is reviewed. The Federal government and Callfornia recognize a geothermal system as being an energy resource. It was concluded at the hearing that the energy produced is direct product of the molten minerals and gases within the resource. The water which transports the energy to the surface is a conveyor belt, nothing more. The total resource has all of the basic characteristics of those resources which the courts have classified as minerals on many occastons in many jurlsdictions. The water condensed from the resource is not necessary for or beneficial to the use of the land. The surface owner wants the energy which the water carries, not the water itself. It is for these reasons that the court held that the plaintiff is the owner and entitled to the possession and control of all the geothermal steam and power and geothermal resources in and under the subject property by virtue of its leasehold interest. (MCW)

34 LEASE OF FEDERAL GEOTHERMAL ENERGY: ROCKY ROAD (ABSTRACT). Stark, D. (Bureau of Land Management, Billings, MT). Am. Assoc. Pet. Geol. Bull.; 60: No. 8, 141 o(Aug 1976).

From 25. annual meeting of AAPG--SEPM Rocky Mountain Sections; Billings, MT, USA ( $2 B$ Mar 1976).

LAND LEASING; GEOTHERMAL RESOURCES;GOVERNMENT POLICIES: PUBLIC LANDS

35 (SAN--1077-4, PP XIII.1-XIII.10)

DEFINITION DF AN INSTITUTIONAL STRUCTURE. Cady, D.P.; Jeskey, J.C. I3 Jul 1976. Susanville Geothermal Energy Project. Workshop proceedings final technical report. The rationale and procedures used in selecting and structuring the candidate SGEP administrative vehlele are described. The institutional structure is bounded not only by legal conslderations but is more stringently constrained by fundamental needs of the community. Criteria and considerations for the planning of local ordinances have also been included.

36 (SAN--1077-4, PP I.1-I.6) SUSANVILLE GEOTHERMAL ENERGY PROJECT OUERVIEW. LONgyear, A. B. 13 Jul 1976 .

Susanville Geothermal Energy Project.

Horkshop proceedings final technical report.

The Susanville Geothermal Energy Project

(SGEP) has produced engineering procedures and economlc modeling tools as alds for communtiles in planning for the development and use of geothermal energy. These tools have been developed based upon the needs and characteristics of Susanville, Callfornia, and elght other communities in six states. The rationale for structuring of institutional and financial vehicles has been included. Project and IInanclal planning for a community geothermal utility system for industrial, commercial and residentlal users is offered as a gulde to other communities.

37 (SAN--1077-4, PP II.1-II.16) SUSANVILLE PROJECT REQUIREMENTS. Edson, D.A. (VTN Consolidated, Inc., Irvine, CA). 13 Jul 1976. Susanville Geothermal Energy Project. Horkshop proceedings final technical report. The Susanville Geothermal Energy Project Study Area may be characterized as a typlcal small U.S. east slope community as to its socioeconomic base. Its economy is heavily dependent on forest products, agriculture and ranching and government employment at all levels. Employment is highly seasonal with unemployment figures as high as 24 percent. Its renoteness from major markets, compounded by Inadequate rall and air service represent potential growth barriers. Present energy sources are expensive and unreliable. Conversely, these very factors tend to enhance the desirability of a brosd based use of geothermal energy, if this resource can be properly developed and controlled. The avallablilty of trained labor, favorable planning and governmental attitudes and attractiveness of the area are positive assets. Preliminary investigation has indicated that Agribusiness, discussed in another paper, Forest Products, Space Heating, and possibly Power Generation, may be potential areas of geothermal development.

38 (SAN--1077-4, pP XII.1-XII.34) SOCIOECONOMIC MODEL. Gardner, R.J.: Whitney, H.H. (WI 11 ams-Kuebelbeck and Assoclates, Inc., Marina del Rey, CA). 13 Jul 1976.

Susanville Geothermal Energy Project.

Workshop proceedings final technical report. The Soclo-Economic Model has been designed to enable the user communities to project the community-wide impacts of proposed industrial enterprises related to the utilization of the geothermal resource. The Model has been prepared in handbook format to facilitate its use.

39 (SAN--1077-4, PP XVI.1-XVI .14)

CHARACTERISTICS OF NINE COMMUNITIES CONSIDERING GEOTHERMAL UTILIZATION. LONgYEAT, A.B. 13 Jul 1976.

Susanville Geothermal Energy Project. Workshop proceedings final technical report. The Utillzation Panel, composed of Replicable Communities, was formed as a means of expediting the transfer of technology from the SGEP to other communitles. Panel member communities were selected on the basis of having characteristics different than those of Susanville. These differences were used to assure that the engineering and economic modeling procedures would be developed having a wide range in application. A Newsletter has been published quarterly to further disseminate project results. An industrial geothermal laboratory has been evaluated and formation steps initiated.

40 (SAN--1077-4) UnCl SUSANVILLE GEOTHERMAL ENERGY PROJECT. WORKSHOP PROCEEDINGS FINAL TECHNICAL REPORT. Longyear, 
A.B. (Energy Research and Development Administration, Washington, D.C. (USA). Div. of Geothermal Energy). 13 Jul 1976. Contract E(04-3)-1077. 249p. Dep. NTIS \$8.00. Separate abstracts were prepared for the 16 papers presented in ERA; 10 are included in EAPA. (WHK)

41 (SAN--1077-4, pP XVII.1-XVII.9) SUSANVILLE GEOTHERMAL UTILITY SYSTEM. Longyear, A.B. $13 \mathrm{Jul} 1976$.

Susanville Geothermal Energy Project. Workshop proceedings final technical report. Program planning has been conducted in support of the SGEP for the current phase and for a plan for a community geothermal utility system. The rationale behind the planning has been Included for use by others. Planning is detalled for the financing (Including application for an ERDA guarantee) for the first thermal unit of the Susanvilie Geothermal Utility System (SGUS).

42 (NP--21355) UnCl MINING AND MINERALS POLICY: 1976 BICENTENNIAL EDITION. (Department of the Interior, Washington, D.C. (USA)). Jul 1976. 135p. GPO.

The report is organized into three basic parts. The first part, the Executive Summary, provides a brief description of the major toples and 1 ists the issues and recommendations. The report then is divided into two sections. Section I, Summary, is comprised of three chapters: Increased Energy Security; Metals and Nonmetallic Minerals; and Trends and Events. Section II, I ssues in Energy and Minerals Pol Vey, is comprised of seven chapters: Federal Leasing; The Federal Role in Reducing the Fiscal Impacts of Energy Development; Avallability of Federal Lands for Mineral Exploration and Development; Environmental Issues and the Mineral Industry; Developments in International Minerals Trade and Investment; Ocean Mining; and The Development of New Tools for Energy and Minerals Polley Analysis. (MCH)

43 (TID--3354-R1) UnCl GEOTHERMAL RESOURCES: EXPLORATION AND EXPLOITATION. A BIBLIOGRAPHY. (Energy Research and Development Administration, Oak Ridge, Tenn. (USA). Technical Information Center). Jul 1976. 636p. Dep. NTIS \$16.25.

This comprehensive bibliography contains 5476 citations of foreign and domestic research reports, journal articles, patents, conference proceedings, and books concerned with the exploration and exploitation of geothermal resources. The coverage dates back as far as useful references could be obtained and extends through June 1976. References are arranged in broad subject categories and are made up of complete blbllographlc cltations. These are followed by a listing of subject descriptors used to describe the subject content of each reference. Four Indexes are included:

Corporate, Personal Author, Subject, and Report Number. Al so included is a 1 lst of journals from which articles were selected. (LBS)

44 (JPL- -5040-25(Rev.A)(APp.)) Unel GEOTHERMAL ENERGY IN CALIFORNIA: STATUS REPORT - (Jet Propulsion Lab., Pasadena, Calif. (USA)). 30 Jun 1976. vp. Energy Resources Conservation and Development Commission.

The potential for electric energy from geothermal resources in Californla is currently estinated to be equivalent to the output from 14 to 21 large ( $1000 \mathrm{MW}$ ) central station power plants. In addition, since over 30 California citles are located near potential geothermal resources, the non-electric applications of geothermal heat (industrlal, agriculture, space heating, etc.) could be enormous. Therefore, the fuli-scale utilization of geothermal resources would have a major impact upon the energy picture of the state. This report presents a summary of the existing status of geothermal energy development in the state of Callfornia as of the eariy part of 1976. The report provides data on the extent of the resource base of the state and the present outlook for Its utilization. It identifies the existing local, state, and federal laws, rules and regulations governing geothermal energy development and the responsibilities of each of the regulatory agencies involved. It also presents the differences in the development requirements among several counties and between Calleornia and its neighboring states. Finally, it describes on-golng and planned activities in resource assessment and exploration, utilization, and research and development. Separate abstracts are prepared for ERDA Energy Research Abstracts (ERA) for sections II--VI and the three Appendixes.

45 (JPL--5040-25(Rev.A)(App.), pp 3.1-3.25) PRESENT PLANS FOR UTILIZATION OF GEOTHERMAL ENERGY. 30 Jun 1976.

Geotheral energy in Callfornia: status report.

The current outlook for the utilization of the hydrothermal resources is presented. The plans of the utilities for adding new generating capacity over the next 20 years and the role of geothermal energy in those plans are included. The data on electrical utilization was gathered from interviews with those utilities that have been identified as active or interested in geothermal energy. Nonelectric application of geothermal energy in the state is limited primarily to the Susanville area, where ERDA is supporting a study on the total use of geothermal resources, and the Imperlal Valley, where the Bureau of Reclamation is conducting desalination research. As a result the data on nonelectric ut1lization was drawn from previous JPL Interviews and analyses augmented by the data on current research and development activities of the Federal Government.

46 (JPL--5040-25(ReV.A)(APp.), PP 6.1-6.14) RESEARCH AND DEVELDPMENT. 30 JUn 1976. Geothermal energy in Callfornia: status report.

The research and development activities under way in the nation that could be of assistance to geothermal development activities in the state are presented. The Federal government has a large and increasing budget to support geothermal energy development in the nation. The geothermal research and development activities. of many of the state's educational institutions are supported by this program. The Federal Government programs as well as those of the Callfornia Energy Resources Conservation and Development Commisslon, the State Lands Commision, and the Electric Power Research Institute are summarized.

47 (JPL--5040-25(Rev.A)(App.), pp 4.1-4.34) GEOTHERMAL RESOURCE DEVELOPMENT PROCESS. 30 Jun 1976.

Geothernal energy in California: status report.

A description is given of the development and approval process governing geothermal development in the state. An overview of the 
development process in California on federal, state, and private lands is presented, and the involved agencles and thelr roles and responsiblilties in that process are described. The key differences between the development in californla and neighboring states are Identifled. Estimated development timelines are presented as are flowcharts depicting adminlstrative processing time requirements. The results indicate that, on federal land in Californla, development of an electric power plant is estimated to require 9 years from the time the decision is nade to explore to the $t$ ine poirer would be on-line. For a nonelectrical application on rederal land, the estinated time frame would be 5 years. Corresponding results for private and state lands are estinated to be approxinately 8 years for an electric power plant and approximately 4 years for a nonelectric application. The priaary reason for the shorter estimated development time on nonfederal land is that less time would be required for leasing land and less time would be requiled for the Environmental Impact Report process than for the Environmental Impact statement process (when required under California Environmental Quality Act and National Environmental Protection Act).

48 (JPL--5040-25(Rev.A)(APp.), pp A. 1-A. 108) APPENDIX A: GOVERNANCE OF GEOTHERMAL ENERGY DEVELOPMENT. 30 Jun 1976.

Geothernal energy in california: status report.

Geothermal development in California requires number of government permits and approvals by local, state, and federal ageneles. The procedural detalls by which governmental agencies implement the regulatory iramework of their respective jurlsdictions (1.e. state, federal, or county) are presented in this appendix. Since the involvement of some public agencies is related to (but not totaliy dependent upon) the ownershlp of the land under which the resource is located, a brief discussion of resource ownership litigation precedes the discussion of public agency roles.

49 (JPL--5040-25(Rev.A) (APP.), PP B.1-B.11) APPENDIX B: ADMINISTRATIVE REQUIREMENTS FOR DEVELOPMENT OF GEOTHERMAL RESOURCES. LYONS, T. 30 Jun 1976 .

Geothermal energy In California: status report.

Development of geothermal resources hinges, on close coordination and cooperation between two bodies: first the individual or entity with a will to invest money by engeging men and equipment for di scovery and development, and second the government agency with jurisdiction over the resource itself or the activity on the surface above. This paper is written to help the reader understand the second body by viewing the numerous agencies to be deait with, the public purposes they serve, and the requirements they impose upon the first body. Statutes and rules pertaining to the state of Oregon are used ince they are tair representation of what would be encountered in other states. Only those requirements which reveal the agency's main area of concern are expressiy mentioned.

50 (LBL- 5204) UnCl PUBLIC OPINION IN COBB VALLEY CONCERNING GEOTHERMAL DEVELOPMENT IN LAKE COUNTY, CALIFORNIA. Vollintine, L.; Weres, 0. (Callfornia Univ., Berkeley (USA). Laurence Berkeley Lab.). Jun 1976. Contract $W-7405-E n g-48$. 44p. Dep. NTIS $\$ 4.00$.

In the Spring of 1975 the friends of Cobb, a local environnental group, polled the registered voters of the Cobb Valley precinct, Lake County, California, about their opinions regarding the development of geothermal energy in Lake County. Sixty-five percent of those polled responded, and an analysis of thelr responses indicates the following: (1) The people of the Cobb Valley (which lies directly in the path of geothermal development) are rather less pleased with the prospect than a previous poll has shown the people of lake County as a whole to be. As measured by an index of general support for development, onethird of the Cobb people are for development, one-third are agalnst, and the remalning third are undecided or have mixed reelings. (Countywide, nearly two-thirds support development.) (2) Support for and opposition to geothermal development correlate most highly wth the perception of envlronmental impacts, the expectation of economlc benefits in the lorn of Increased job opportunities and tax revenues, and size of land holdings. (3) Among those who own more than ten acres of land, the willingness to lease land for geotheral development correlates most highly wh the perception of environmental impacts.

51 (NP--21256) UnCl SUMMER LAKE BASIN GEOTHERMAL LEASING: ENVIRONMENTAL ANALYSIS RECORD, Brolll, C.; Cannon, $W_{\text {. }}$, Depaoll, E.: Doughty, L.; Hammersmark, M.: Hill, D.: Schlagel, M. (Bureau of Land Management, Lakeview, Oreg. (USA). Lakeview District). Jun 1976. 176p. Bureau of Land Management, Lakeview, OR.

The Impact of proposed geothermal resource leasing on National Resource lands in a portion of the Lakeview B.L.M. District is analyzed. Included are: a description of proposed action. description of the exlsting environment, an analysis of proposed action and alternatives, possible mitigating or enhancing measures, recommendations for mitlgation, residual impacts, relationship between short-tera use and long-term productivity, and Irreversible and irretrlevable commltments. (MHR)

52 (NTIS/PS--76/0462) UnCl GEOTHERMAL ENERGY. VOLUME I. $2964--A P R I L 1975$ (CITATIONS FROM THE NTIS DATA BASE). REPORT FOR 1964-APR 1975. Smith, M.F. (National Technical Information Service, Springfleld, Va. (USA)). Jun 1976. 153p. Nris $\$ 25.00$.

A11 aspects of geothermal energy are covered including development, prospecting, technology, and corrosion problems. This updated blbllography contains 148 abstracts.

53 (NTIS/PS--76/0465) Uncl GEOTHERMAL ENERGY. VOLUME 2..1975--APRIL 1976 (CITATIONS FROM THE ENGINEERING INDEX DATA BASE). REPORT FOR 1975--APR 1976. Salth, M.F. (Nationel Technical Information Service, Springfleld, Va. (USA)). Jun 1976. 174p. NTIS $\$ 25.00$.

These cltations of geothermal worldwide research are mainly concerned with geotheraal energy assessment, prospecting, geology, and well drilling. Studies on heating, refrigeration, electric power generation, and stean heating are also included along with reports on Government pollcies, environmental impacts, and englneering. (Contains 169 abstracts)

54 GEOTHERMAL ENERGY AS AN 'ALTERNAT IVE' SOURCE. Garnish, J.D. (Atomic Energy Research Establishment, Harwell, Eng.). Energy Pollcy; 4: No. 2, 130-143( Jun 1976). Geothernal energy is recelving increasing 
attention, with over sixty countries now looking seriously at the possibility of its exploitation. Al though, for most parts of the world, a nonrenewable resource, new techniques such as pressure fracturing of rocks, could very considerably extend the resource base. Geothermal energy offers promise of becoming a very important complementary source in many parts of the world, providing heat up to about $250^{\circ} \mathrm{C}$ and releasing premiun fuels for applications requiring higher temperatures or transportability. (editor's sumary)

REPLY FROM THE FEDERAL GOVERNMENT CONCERNING NEU PRIMARY ENERGY SOURCES. Laermann, K.H.; Blank, B.; Haenschke, F.: Lohmar, U.; Meinecke, R.: Scheffler, H.; Schluckebler, G.; Stahl, E.; Wendt, M.; Wolfram, E. (Deutscher Bundestag, Bonn (F.R. Germany)). Bundesrat - Drucksache; No. 7 : 5313, 1-12(Jun 1976). (In German).

A safe energy supply is of central importance for all national economies, and in particular for industrialized countrles like the FRG. In view of this special inportance, energy pollcies have a high priority within the overall pollcies. The Federal government has taken account of this fact in the energy program of September 1973 and its first continuation in the autumn of 1974, and it has thus presented a modern overall concept from the view of energy policies. In connection with this program, energy research ranks very high because in the long run it offers important possibilities for the energy supply of the FRG. Coal, the only source of energy in the FRG which is avallable in abundance, stands well to the fore of the program. Hithin the framework of this program, research and development activities have been inftiated for utilizing the regenerative primary energles sun, wind, geothermal energy, and fresh and salt water energy. The utilization of these kinds of energy, belonging predominantly to the group of primary energy carrlers with a limited capacity is, generally speaking, more in the environmental interest than the utilization of those kinds of energy which are dependent on resources: in the former cases no additional energy is brought onto the earth's surface, but avaliable natural energy generation is used. (tr-auth)

56 ENERGY ECONOMICS. Liberman, L.M. Am. Gas Assoc. Mon.; 58: No. 6, 4-7, 32 (Jun 1976). From A.G.A. marketing conference; Boston, MA (16 Mar 1976).

The history of natural gas and its development restrictions said to be due to governmental regulation are considered. The Supreme Court's Phillips Decision in June 1954 which ruled that the FPC had both the jurisdiction and responsibility for regulation of the wellhead price of natural gas, is discussed. The Phillips Decision determined that Congress meant only to exempt the physical act of production and gathering from regulation but not the sales that resulted from that act. Natural gas well head price became seriously underpriced and discoveries decllned continuously after the early 1960s. Passage of the 1967 Alr Quality Control Act caused a decline in the use of coal in industry since natural gas was cheaper. The natural gas Industry could not meet demand, fuel oil refining had declined, and coal development had decreased. An economic comparison is made of Btus in the forms of OPEC and old and new U. S. oll, natural gas, and coal. It is concluded that if a long-range supply of petroleum products are to be forthcoming, coal reserves w11 have to be 1 lquefled and gasified. (MCW)
57 REPLY BY THE FEDERAL GOVERNMENT TO A QUESTION CONCERNING NEW PRIMARY ENERGY SOURCES RAISED IN THE BUNDESTAG. Matthoefer, $H$. (Bundesministerium fuer Forschung und Technologle, Bonn (F.R. Germany)). Bundesrat Drucksache: No. 7:5313, 1-11(Jun 1976). (In German ).

A question ralsed in the Bundestag concerning new primary energy sources was answered by the Federal Minister for science and Technology in hls letter dated June 2, 1976; the letter called attention to the Federal Government's energy program of September 1973 which, instead of promoting research almost exclusively on the nuclear sector as used to be the case, alms at a purposeful and comprehensive promotion by the state or nonnuclear energy research as well in the FRG. Solar energy seems to have the best chance in the FRG of being utilized in an industrial way, applying low-temperature collectors to recover heat for heating and hot water preparation; 28 million DM have been invested so far. Despite the fact that the technical potential of wind power in the FRG would cover almost $75 x$ of the present electricity demand, only plants with a small $\mathrm{kW}$ range are being developed at the moment as the question of energy storage is still open; 0.3 million DM have been granted $s 0$ far. The utilization of geothermal power can only be of interest for the FRG on the basis of the hot-dry-rock method; drilling work is carried out in the Eifel district investigating geothermal gradients: 1.25 million DM have been granted so far. In 1976 the projects mentioned above have been allotted research funds amounting to 20 million DM. Energy from running/ tidal waters is utillized in the FRG to $90 \times$ so far, but this only accounts for $6.7 x$ of the gross electricity generation. Therefore, its importance for the energy supply of the FRG will decrease when the energy demand increases.

58 GEOTHERMAL ENERGY RESEARCH, DEVELOPMENT, DEMONSTRATION, AND PRODUCTION; FEDERAL GUARANTEES ON LOANS. Seamans, R.C. Jr. Fed. Regist. (Wash., D.C.): 41: No. 103, 2143321440 (26 May 1976). (10CFR790).

On October 28, 1975, the Energy Research and Development Administration published a proposed regulation concerned with enabling lenders to obtain Federal guarantees on loans to qualified borrowers for purposes related to the commerclal development of practical means to produce electric power and other forms of useful energy from geothermal resources in an envi ronmentally acceptable manner. The objectives of the Federal geothermal loan guaranty program are: (a) to encourage and assist the private and public sectors to accelerate development of geothermal resources with envi ronmentally acceptable processes by enabling the Administrator of the Energy Research and Development Administration, in the exerclse of reasonable judgment, to minimize a lender's linancial risk that is associated with the introduction of new geothermal resources and technology; and, (b) to develop normal borrower-lender relationships which will in time encourage the flow of credit so as to assist in the development of geothermal resources without the need for Federal assistance. The regulation became effective June 25, 1976. ( $\mathrm{MCW}$ )

59 (UCRL--52000-76-5, PP 21-26) IMPERIAL VALLEY ENVIRONMENTAL PROJECT. MaY 1976. Energy and technology review. ERDA has designated LLL to head up a twoyear environmental study that should allow 
government, power-company officlals, and other interested parties to assess the impact of geothermal developnent on California's Imperial Valley. The study, funded at $\$ 2.4 \mathrm{mill}$ ion for FY 1977, w11 involve some 40 LLL investigators, 25 university contractors, and several state and local governmental agencies. Work on the project is now under way. Mafor research areas of this coordinated study Include alr and water quality, effects on the ecosystem, subsidence and induced seismlcity, health effects, and socioeconomic impacts. The study will include an integrated assessment to facilitate decision-making.

EX-ASSISTANT ADMINISTRATOR LOOKS BACK DN ERDA'S 1 ST YEAR....AND AHEAD TO 2ND. Energy Res. Rep.: 2: No. 5, 7-11( May 1976).

This interview with Dr. Teem, Cormer assistant administrator of solar, geothermal, and advanced energy systems, was conducted March 18 and updated April 5, 1976. Among other things Dr. Teem revealed that, after three months of ERDA's existence, 60 percent of the Incoming mall concerned solar energy. After di scussing government actions regarding solar energy-budgets, technology, and progress--Dr. Teem then comments on other programs formerly under his leadership--geothermal, controlled thermonuclear fusion, and high-energy physics. He feels the potential for geothermal is surprisingly good. In answer to another query, he does not feel that a Department of Energy and Natural Resources is needed at this time. (MCW)

61 PACIFIC NORTHWEST GEOTHERMAL: REVIEW AND OUTLOOK. Youngquist, $W$. Geotherm. Energy Mag.; 4: No. 5, 28-3i( May 1976).

A review is given of some of the more signlficant geothermal exploratory developments this past year in Idaho, Oregon, and Washington. The critical role of the U.S. Government in development of the se geothermal resources is described. (MOW)

62 GREIDER GEOTHERMAL STATEMENT, BASED DN TESTIMONY PRESENTED TO LT. GOV. DYMALLY COMMITTEE. Grelder, B. Geotherm. Energy Mag.: 4: No. 4, 27-29, 31-34, 36-37(Apr 1976). Factors that contribute to the delay of geothermal development by utilities are discussed. These include: the Increasingly complex regulations on the Geysers fleld; low quallty and sizes of hot water resources: economfics of financing geothermal exploration; professional experlence; and lack of falth in the technology of conversion of hot water into electricity. Key issues that must be resolved before geothermal development can significantly penetrate the electricity generation industry are presented. It is pointed out that legislation to stimulate development of California's geothermal resources should be based on consideration of the following items: streamlined controls which allow geothermal exploration and development to proceed under a minimum of effective regulation; reasonable tax provisions encouraging exploration, research, development, and production of geothermal energy; and suitable economl c incentives for utility companies that will encourage early commi tment to construct generating plants. (LBS)

63 FEA: PRICES HOLD KEY TO ENERGY FUTURE. 011 Gas J.: 74: No. 11, 60-61(15 Mar 1976). The Federal Energy Administration palnts a bleak picture of the U.S. energy out look unless 011 and gas prices are deregulated, OCS developuent is pursued, and strong government support is provided for al ternate fuels. This is the maln thrust of the agency's new National Energy Outlook, an update of its November 1974 Project Independence report. The new forecast makes little mention of $1980 \mathrm{goals}$, when energy Independence orlginally was to be the target, but does refer of ten to the outlook for 1990 . If oll and gas prices continue to be regulated at low levels, oll lmports, now averaging about $6 \mathrm{milll}$ on $b / d$, could rise to $13.5 \mathrm{milli}$ ion $b / d$, the report projects. With intensely accelerated production of both onshore and offshore sources under free-market prlcing and increased conservation efforts, imports could drop as low as 1-2 million b/d by 1985. FEA, however, feels this is highly unlikely. Its actual forecast is that even with current world prices, oll and gas price decontrol, and present ocs production plans, Imports will drop only slightly in 1985 to 5.9 allilion b/d. FEA has trimned its expectations for nuclear power's contribution to future energy needs. And it now says new technologies such as solar, geothermai, and synthetic fuels will contribute only 1 percent by 1985 and will have major contributions only after 1990--if force fed by the Government. (from Introduction)

64 (CONF-760205-, PP 120-143) OTHER ENERGY SOURCES. Postma, H. (Oak Ridge National Lab., TN ). Mar 1976.

From HATTec symposium for public awareness on energy; Knoxville, Tennessee, United States of America (USA) (27 Feb 1976).

Energy awa reness.

Solar energy, geothermal energy, and fusion energy sources are discussed with answers provided for the following questions: how large is the resource; what is the state of the technology: what are the engineering problens; how economical is $1 t$ now or can it ever be; what are institutlonal, legal, and political problems; what are the environmental effects: is it acceptable; and how long will it take to be economical and to make a reasonable Impact. Recoverable domestic energy resources in the U.S. are reviewed, and the ' 'hlstoricall' time span to change energy sources is cited. Topics discussed on solar energy include direct applications, solar electric generation, terrestrial and marine blomass production, and wave and tidal energy. The cafegories covered in the discussion on geothermal energy include dry stean systems at the Geysers; hot water: geopressured systems; hot dry rock systems; and heat that could be derlved from normal thermal gradlents and magma. The two approaches that are being taken to develop fusion energymagnetic conflnement and laser fusion-are discussed brferly. A brief discussion is included on solfd-waste conversion to fuel or to be directly burned. The basic problem in U.S. energy polley is how to get from 1976 to the days of solar, geothermal, or sollid-waste utillzation for energy (MCW)

65 (LBL-4447) UnCI PUBLIC ÓPINION CONCERNING GEOTHERMAL DEVELOPMENT IN LAKE COUNTY, CALIFORNIA. Vollintine, L.: Weres, 0. (Callfornia Univ., Berkeley (USA). Lawrence Berkeley Lab.). Mar 1976. Contract W-7405Eng-48. 55p. Dep. NTIS \$4.50.

A random sample of 2500 of the registered voters of Lake County, California, were polled about their oplnions regarding the prospect of the development of geothermal energy in Lake County. The results of a secondary analysis of their responses are presented. The main conclusions are: (1) A large majority of the respondents are in favor of geothermal development provided that it is sultably 
regulated to minimize negative environmental impacts. (2) The main determinants of the respondent $s^{\circ}$ approval or disapproval of geothermal development are their expectations concerning the environmental impacts of geothermal development and the economic benefits of development for the county. Essentlally all respondents who do not percelve negative environmental impacts support development, and the expectation of increased job opportunities and/or tax revenues is a nearly absolute prerequisite for support of development. (3) Pro- and ant I-geothermal blas have strong effects upon the formation of opinlons about leasing and the perception of environmental Impacts. (4) Purely demographic characteristlcs of the respondents, such as employment status and years of residence in the county, have only linited effects upon the Ir at itudes toward geothermal development except in the southern portion of the county, where longer term residents and those who live in the county for reasons of employment are more in favor of development.

66 (MTR--7137) UnC1 GEOTHERMAL ENERGY RESOURCE UTILIZATION PROGRAM PLANNING. Grover, F.T. (Mitre Corp., McLean, Va. (USA)): Mar 1976. Contract $E(11-1)-2693$. 44p. $(C 00 / 2693--76 / 1)$. Dep. NTIS $\$ 4.00$.

ERDA's basic strategy for creating al ternative energy supplies is to conduct a progran of research, development, and demonstration of energy technology which induces and aids private exploltation of, in this case, geothermal energy resources (commercialization). So that the existence of (user) cholce is demonstrated, and as means of channellzing efforts for the mitigation of the nation's gathering crisis in energy supply, speciflc commerclallization goals have been set by ERDA. A procedure is described for planning the achievement of the commerclallzation goals established for geothermal energy resources. It has been prepared for the consideration of the Office of Resource Utilization, of ERDA's Division of Geothermal Energy.

67 (NP--21229) UnCl GEDTHERMAL RESOURCES, PRESENT AND FUTURE DEMAND FOR POUER AND LEGISLATION IN THE STATE OF WYOMING. PUBLIC INFORMATION SERIES 1. Decker, E.R. (Wyoming Geological survey, Laramie (USA)). Mar 1976. 24p. Wyoming Geological Survey, Laramie $\$ 0.50$.

Data on thermal springs and wells in Hyoming, exclusive of Yellowstone Park, are summarized. The presentation includes map showing general spring and well locations outside the Park and lands in Hyoming that have been classifled as belng prospectively of geothermal value. Locations and geothermal data on the springs and wells are tabulated and a short table of chenical analyses of spring waters is al so presented. Al though thermal dato constitute most of the material presented, the present and future demands for electrlcal energy in Wyoming are al so summarized, and state legisiation pertaining to exploration near thermal springs is reviewed. A list of state and federai agencies is included so that interested parties may obtain coples of pertinent legislation and information on the status of land.

\section{8 (TID--27034) UnCl ENVIRONMENTAL} ASSESSMENT OF PROPOSED GEOTHERMAL UELL TESTING IN THE TIGRE LAGOON OIL FIELD, VERMILION PARISH, LOUISIANA. (Energy-Research and Development Administration, Washington, D.C. (USA). DIV. of Geothermal Energy: Coastal
Envi ronments, Inc., Baton Rouge, La. (USA)). Mar 1976. 97p. Dep. NTIS \$5.00.

An environmental assessment is made of the proposed testing of two geopressured, geothermal aquifers in central coastal Loulsiana. On the basis of an analysis of the environmental setting, subsurface characteristics, and the proposed action, potential environmental impacts are determined and evaluated together with potential conflicts with Pederal, state, and local prograns. (LBS)

69 GEOTHERMAL ENERGY: AN INDUSTRY APPRAISAL. Olson, H.J.; Dolan, H.M. Min. Congr. J.; 62: No. 3, 18-21( Mar 1976).

Some deterrents to the rapld development of geothermal energy by industry are discussed. It is pointed out that those groups in the business of pursuing subsurface resources will be motivated to rapidly develop a geothermal Industry if: (1) real istic definttions of known geothermal resource areas (KGRAs) are provided: (2) the agency prerogative concerning creation of KGRAs are severely restricted; (3) noncompetitive leases are promptly issued; (4) escrow provisions or other arrangements are implemented, permitting geothermal leases to be issued on the federal mineral estate: (5) acreage ifmltations per state are substantially increased; (6) tax legislation, specifically for geothernal, is enacted that provides for intanglble drilling cost deductions, depletion allowances or equivalents: and accelerated write-offs; (7) the already legislated guaranteed loan program is implemented with expeditions processing requirements; and ( 8 ) environmental compliance procedures are streamlined. (LBS)

70 ROLE OF THE STATE LANDS DIVISION IN DEVELOPING GEOTHERMAL RESOURCES IN CALIFORNIA. Northrop, W.F. Geotherm. Energy Mag.; 4: No. 3, $13-14$ (Mar 1976).

The state Lands Commission has jurisdiction over approximately one half million acres of land of geothermal potential. The Commission issues prospecting permits and leases for the exploration and development of geothermal resources under provisions of the Public Resources Code, the Californis Adminlstrative Code, and the Geothermal Resources Act of 1967. Certaln detalis of these provisions are discussed. Pending legislation, Senate BIII 517, will make some major provislons in the law dealing with the exploration, development, and utillzation of geothermal resources. If the bill is approved, the prospecting permit procedure will be eliminated and all state leases $w 11$ be issued by competitive public bid. Other aspects of the pending leglsiation are discussed. (LBS)

71 OBSERVATIONS ON FEDERAL ENERGY RESEARCH AND DEVELOPMENT, DECEMBER 1974. Weinberg, A.H.; Burwell, C.C. (Federal Energy Adul nistration, Washington, DC). Energy (Oxford); 1: No. 1, 3-9( Mar 1976).

Much of our country's present stance in energy $R$ and $D$ is an embodiaent of the recommendations presented in the Dixy lee Ray report, "The Nation's Energy Future." Since that report appeared, the Energy Research and Development Administration was established, and the Project Independence Blueprint was completed. To what extent does the passage of a year change the priorlties or the scale of energy research and development which was outlined in NEF. This memorandum recommends a few specific $R$ and $D$ programs and related insti tutional changes that ought to be undertaken in response to events that have 
occurred since November 1973. (Ed. note: although this "observations'" report was completed in December 1974--and was originally intended only as an internal meno-it was published here because of its historical value and because the subject continues to be tinely.)

72 BOOH TOWNS MAY HINDER ENERGY RESOURCE DEVELOPMENT. GIImore, J.S. (UnIV. of Denver Research Inst.). Sclence: 191: No. 4227, 535$540(13$ Feb 1976$)$.

The development of a community in an area where an energy source is being developed can be a rustrating situation for local and state governments charged with protecting the health, safety, and welfare of their populations.

PIstol Shot, USA, Is selected as an Imaginary typical western community about to be lmpacted by the development of coal, oll shale, uranium, or geothermal resources. PIstol Shot is 100 iles from a town of as many as 10,000 or 15,000 people: it is more than 200 miles from a metropol iten area. It is dependent on its own resources, Is a county seat in a sparsely settled ranching country, although there was some mining in the past. Its population in 1970 was 1200. Accelerated development of energy wll cause the community to be unable to furnish services and lacilities needed to acommodate the population growth. When this happens, productivity declines, projects overrun time and cost schedules, and operating outputs fall behind. The state 111 be needed to help in management growth. Untli each state can modify its laws, taxes, and its constitution, substantial. Federal governaent help w11l be needed. Current ways of doing things also need to be modifled by the energy industry, local governments, and the nass aedia. ( $\mathrm{MCW}$ )

73 (NP--21008) UnC1 PROPOSED ENERGY RESEARCH AND DEVELOPMENT PROGRAM: FISCAL YEAR 1976/77. CALIFORNIA ENERGY RESOURCES CONSERVATION AND DEVELOPMENT COMMISSION. (California Energy Resources Conservation and Development Commission, Sacramento (USA)). Feb 1976. 187p. (RD--76-1). TIC. Californla's proposed $1976 / 1977$ energy research and development program is a practical, Integrated effort designed to be of significant benefit to California over the near and long term. It is almed at finding, developing, and facilltating the widespread use of economically attractive, alternative energy systems having minimal adverse environmental impact. The results of this program will expand the energy optlons avallable to callfornians. It will enhance personal, local, and state level control over the energy future. Further it wil facilitate innovative, constructive responses on the part of Californians to the rapidly changing nature of the energy problem. ... In particular, this progran concentrates on neu conservation technlques and alternative energy sources, especially solar and geotherabl energy. In addition new options for the iting of the State's energy faclilities will be further developed. However, new technologles are only one apect of what is needed to resolve state energy problems. An equally inportant aspect involves ensuring the broad appilication of these new techniques in all regions of California, and the task of promoting rapid market penetration of worthwile new technologies will be designed Into each program and project from the tart. The proposed program has been divided into seven program areas: Solar Energy: Geothermal Energy: Conservation and Efficiency: Inter-Program
Projects: Fuels; Transportation: and Utility Systems. (Irom Overview and Sumary)

74 (NP--21381) Uncl SOME ISSUES REGARDING REGULATORY POLICY, POLITICAL PARTICIPATION, AND SOCIAL IMPLICATIONS OF GEOTHERMAL RESOURCE DEVELOPMENT IN THE IMPERIAL VALLEY. Green, P.S.; Steinberger, M.F. (California UnIV.? Riverside (USA). Center for Soclal and Behavioral Sclence Research). Feb 1976. 62p. Univ. of California, Riverside.

The early stages of geothermal resource development in the Imperial Valley have been characterlzed by an emphasis on the technological expertise of private developers and government of 1 clals. Government officlal have created a complex array of Federal, state and county regulations to monitor the developuent. Local control is under the Jurlsdiction of the Imperial County government. The County has as its responsibility the protection of the general welfare of its residents, Including any potentially adverse social, economic, or environmental impacts caused by geothermal resource development. Private developers and government officlals are Interested in the resources as a source of water desalination and electric power generation. An assessment of the Interests and concerns of the public was made carly in the development stage. In view of all these interests, it is essential in a democratic soclety that the various interests be Identifled so government can be representative of, and responsive to, those interests. Therefore, the four issues discussed in the paper are: (1) regulatory problems faced by local government officials in determining the course of development: (2) the social and political context in which the development is taking place: (3) the potential of geothermal development as percelved by community leaders and local government offlcials: and (4) the desirability of expanding citizen participation in geothermal decision-makingduring a period in which, as public oplnion polls indicated, many citlzens feel separated from government actions which may signiflcantly affect their lives. Recommendations for regulations of geothermal resources and recommendations for laproving public input into geothermal regulation are sumarized in depth. (MCW)

75 LEGAL ASPECTS OF THE UTILIZATION OF GEOTHERMAL HEAT. Heller, W. Erdoel Kohle, Erdgas, Petrochea o: 29: No. 2, 83-84( Feb 1976). (In German).

At present, there are still no special legal regulations by the Bund or the Laender. For exploration, prospecting and aining there are only the aining laws and the law Issued by the Leender pertaining to water supplies and waterways, both of which also apply to all other 'minerals!. In contrast, Iceland, New Zeal and and the USA have special legal provisions.

76 GEOTHERMAL ENERGY: AN INDUSTRY APPRAISAL. Olson, H.J.: Dolan, H.M. (AMAX Exploration, Inc., Denver). Geothern. Energy Mago; 4: No. 1, 12-18( Jan 1976).

A brlef examination of the geothernal industry includes the following: the nature of the geothermal resource; prospecting concerns: production practlce; marketing aspects: environmental concerns; geothermal is probable abundance; applicable land, legal and Institutional considerations; and Investment and revenue timing compared to mining. It is concluded that if certain legal provisions are promptly made, geothermal will provide the nation with important amounts of energy by 
1990, w111 be acknowledged as one of the cleanest and most desi rable sources of energy, and will be compatible with other land uses. (LBS)

77 ALTERNATIVE ENERGY SOURCES FOR THE UK. Dawson, J.K. (Atomic Energy Research Establ 1shment, Harwell, Eng.). Atom (London); No. 231, 11-20( Jan 1976).

The Energy Technology Support Unit augments the technical and scientiflc resources avallable to the Chief Scientist of the Department of Energy to assist in chosing the energy $R$ and D strategy for the UK. This paper examines the contribution of alternative, renewable energy sources for the UK 25 years or more from now. Over the past 25 years the UK energy demand has been rising steadily at an average about 1.8 percent per year, supply being contributed by petroleum, coal, natural gas, nuclear, and hydro - with a total coal equivalent of 331 million tons. Projections for the next 25 years vary from 550 to 650 intee. Details of conversion of solar, geothermal, wind, tidel, and wave energles are discussed. They are grouped according to whether they would be used primarily to produce heat or electricity. The production of secondary fuels such as ethanol or methane from solar energy is an additional option mentioned, but is not discussed in detail here. A scenario is presented showing the contribution that each of these sources inght be able to make in the year 2000 , providing a vigorous development and exploitation program results in approximate economic parity wi th other energy sources. Results indicate the total contribution will be about 6 to 8 percent of the overall energy demand 25 years hence. Solar and wave energy contributions could have the potential to grow to higher contributions if the blological routes to the recovery and storage of solar energy are included. (MCW)

78 ENERGY POLITICS OF FRANCE. Ornano, M.M. Tech. Mod.: 68: No. 1, 11-12(Jan 1976). (In French).

FRANCE; ENERGY POLICY;ENERGY SOURCES ; ECONOMICS; ENERGY CONSUMPTION ; TAXES; NUCLEAR ENERGY;SOLAR ENERGY; GEOTHERMAL ENERGY; HYDROELECTRIC POWER

79 (CDNF-760222--P1, Pp 47-72) LEGAL INSTITUTIONAL, AND ENUIRONMENTAL. 1976. From 2. geopressured geothermal energy conference; Austin, Texas, United States of America (USA) ( 23 Feb 1976).

Proceedings of second geopressured geothermal energy conference. Volume I. Summary and future projections.

This report is divided into two major sections, Legal Scholarship and Legal Support. Scholarship is distingulshed from support by concentration on abstract analyses of issues which include resource definition, ownership, taxation, and multistate reservolrs. Support is based entirely on those legal tasks called up by the technical work scheduled in the areas of Resource Assessment, Advanced Research and Technology, Institutional and Environmental, and Resource Utilization.

80 (CONF-760222--P5) UnCl PROCEEDINGS OF SECOND GEOPRESSURED GEOTHERMAL ENERGY CONFERENCE, AUSTIN, TEXAS, FEBRUARY 23--25, 1976. VOLUME V. LEGAL, INSTI TUTI ONAL, AND ENVIRONMENTAL. Vanston, J.H.: Elmer, D.B.: Gustavson, T.C.: Kreitler, C.W.; Letlow, K.: Lopreato, S.C.; Meriwe ther, M.; Ramsey, P.: Rogers, K.E.; Hilliamson, J.K. (Texas Univ.,
Austin (USA). Center for Energy Studies). 1976. Contract $E(40-1)-4900$. 415p. Dep. NTIS $\$ 11.00$.

From 2. geopressured geothermal energy conference: Austin, Texas, United states of America (USA) (23 Feb 1976).

Three separate abstracts were prepared for Volume $V$ of the Proceedings of the Conference. Sections are entitled: Legal Issues in the Development of Geopressured--Geothermal Resources of Texas and Loulsiana Gulf Coast: The Development of Geothermal Energy in the Gulf Coast; Socio-economic, Demographic, and Political Considerations; and Geothermal Resources of the Texas Gulf Coast-Environmental Concerns arising from the Production and Disposal of Geothermal waters. ( $\mathrm{MCW}$ )

81 (CONF-760222--P5, pp vp, Part 1) LEGAL ISSUES IN THE DEVELOPMENT OF GEOPRESSUREDGEOTHERMAL RESOURCES OF TEXAS AND LOUISIANA GULF COAST. Elmer, D.B.; Rogers, K. 1976. From 2. geopressured geothermal energy conference; Austin, Texas, United States of America (USA) ( 23 Feb 1976 ).

Proceedings of second geopressured geothermal energy conference. Volume $V$. Legal, Institutional, and envi ronmental.

The legal Issues are discussed in two areas: legal scholarship and legal support. Scholirship is distingulshed from support by concentration on abstract analyses of lssue that Include resource definition, ownership, taxation, and multistate reservoirs. Support is based entirely on those legal tasks called up by the technical work schedule in the areas of Resource Assessment, Advanced Research and Technology, Institutional and Environmental, and Resonance Utillization. The legal section will, in the future, make recommendations and implement procedures designed to assist in the rapld and orderly development of the resource. The PERT (Program Evaluation Revlew Techniques) chart for sequencing of legal scholarshlp and support tasks is included. An oral presentation on geothermal resources in Texas, a resource model for the resource utilization section, and some excerpts from legislation pertaining to geothermal energy are provided in an Appendix. (MCH)

82 (CONF-760222--P5, pp vp, Part 2)

DEVELOPMENT OF GEOTHERMAL ENERGY IN THE GULF COAST: SOCIO-ECONOMIC, DEMOGRAPHIC, AND POLITICAL CONSIDERATIONS. Let IOW, K.: Lopreato, S.C.; MerIwether, M.; Ransey, P.; Willlamson, J.K. 1976.

From 2. geopressured geothermal energy conference: Austin, Texas, United States of America (USA) ( 23 Feb 1976 ).

Proceedings of second geopressured geothernal energy conference. Volume $V$. Legal, institutional, and envi ronmental. The Institutional aspect of the study at tempts to Identify possible effects of geothermal research, development, and utilization on the area and its inhabltants in three chapters. Chapters I and II address key socio-economic and demographlc varlabies. The initial chapter provides on overview of the area where the resource is located. Major data are presented that can be used to establish a baseline description of the region for comparison over time and to delineate crucial area for future study with regard to geothermal development. The chapter highlights some of the variables that reflect the cultural nature of the Gulf Coast, its social characteristics, labor force, and service in an attempt to delineate possible problems with and barriers to the development of geothermal energy in the 
reglon. The following chapter focuses on the local impacts of geothermal wells and powergenerating facilities using data on such variables as size and nature of construction and operating crews. Data are summarized for the areas studied. A flow chart is utillzed to describe research that is needed in order to exploit the resource as quickly and effectively as possible. Areas of interface among various parts of the research that will include exchange of data between the soclal-cultural group and the Institutional, legal, environmental, and resource utilization groups are Identified. (MCW)

83 (CONF-760222--P5, PP vP, Part 3 )

GEOTHERMAL RESOURCES OF THE TEXAS GULF CDAST: ENUIRONMENTAL CONCERNS ARISING FROM THE PRODUCTION AND DISPOSAL OF GEOTHERMAL WATERS Kreitler, C.W.; Gustavson, T.C. (Texas UnIV., Aust $(n)$. 1976.

From 2. geopressured geothermal energy conference; Austin, Texas, United States of Amerlca (USA) ( 23 Feb 1976).

Proceedings of second geopressured geothermal energy conference. Volume $V$. Legal, institutional, and environmental.

An at tempt is made to foresee areas of general environmental concern that will arise during exploration for and development of geopressured-geothermal resources on the Texas Gulf Coast. Disposal of hot saline water and potential subsidence and faulting of the land surface that may result fron geothermal-water production are major concerns. The geology of the area is brlefily discussed followed by detalled discussions on geothermal fluld disposal: potential subsidence and fault activation; and natural hazards of the geothermal fairways. Geothermal resource production faclitities on the Gulf coast of Texas could be subject to hurricane or storminduced flooding, winds, coastal erosion, or expanslve solls. None of these hazards is generated by geothermal resource production, but each has potential for damaging geothermal production and disposal facilities. Production of fluids from geo-pressured geothermal reservolrs $w 11$ result in reservol pressure declines and subsequentiy in compaction of sediments within and adjacent to the reservolr. The magnitudes of envi ronmental limpact of subsidence and fault activation varies with current 1 and use; the greatest impact would occur in urban areas, whereas relatively minor impacts occur in rural, undeveloped agricultural areas. (MCW)

84 (ERDA--76-1(VO1.2)) UnCl NATIONAL PLAN FOR ENERGY RESEARCH, DEVELOPMENT AND

DEMONSTRATION: CREATING ENERGY CHOICES FOR THE FUTURE. VOLUME 2 . PROGRAM IMPLEMENTATION.

(Energy Research and Development

Administration, Washington, D.C. (USA)). 1976. 409p. Dep. NTIS $\$ 11.00$.

The plan for energy $R D$ and $D$ summarlzes the U.S. ERDA's current views on the energy technologles which the Nation will need to achieve longer-term energy independence. This volume identifies those actions that can be taken to Implement the plan described in Volume 1. The document contains descriptlons of the federal energy RD and D programs now underway, as well as possible future efforts. It includes financlal data for FY 75, FY 76 , and FY 77. The description of actions proposed in this volume represents the considered judgment of Federal agency management as to which projects are reasonable to pursue on the basis of infornation now avallable. The document is divided into five parts: energy technology programs, supporting technology programs, energy-related supporting activitles, special analyses, and appendi $x$. The following energy technology programs are discussed: fossil energy (coal, petroleum, and natural gas). solar energy (solar thermal and solar electric energy), geothermal energy, conservation, fusion power, fission power, and the nuclear fuel cycle. (RWR)

85 (NSF/RA--760230) Uncl STATE POLICIES FOR GEOTHERMAL DEVELOPMENT. Sacarto, D.M. (National Conference of State Legislatures, Denver, Colo. (USA)). 1976. 94p. Nat I onal Science Foundation, Washington, DC.

The most prominent geothermal resources in the USA occur in Pifteen Gulf and Western states Including Alaska and Hawal1. In each state, authority and guldelines have been established for administration of geothermal leasing and for-regulation of development. Important matters addressed by these policies include resource definition, leasing provlsions, development regulations, water appropriation, and environmental standards. Some other policles that need attention include taxation, securities regulations, and utllity regulations. It is concluded that conditions needed for the geothermal industry to pursue large-scale development are consumer (utllity) confidence in the resource; equitable tax treatment; prompt exploration of extensive land areas: long and secure tenure for productive propertles; prompt facllity siting and development; and competitive access to varlous consumers. With these conditions, the industry should be competitive with other energy sectors and win its share of investment capital. This publication reviews for the states various technical, economic, and institutional aspects of geothe rmal development. The report summarizes research results fron numerous speciallsts and out Ilnes present state and Federal policles. The report concludes generally that if public policles are made favorable to their development, geothermal resources offer an important energy resource that could supply all new electric capacity for the fifteen states for the next two decades. This energy--100,000 MW--could be generated at prices competitive with electricity from fossil and nuclear power plants. An extensive bibllography is included. (MCW)

86 RESULTS OF AN OPINION SURVEY ON THE 1977 BUDGET PROPOSAL OF THE ENERGY RESEARCH AND DEVELOPMENT ADMINISTRATION. PRINTED AT THE REQUEST DF HENRY M. JACKSON, CHAIRMAN, COMMITTEE ON INTERIOR AND INSULAR AFFAIRS, UNITED STATES SENATE. Washington, DC; Committee on Interior and Insular Affelrs (1976). 75p.

An opinion survey of the 1977 ERDA budget proposal was. sent to 17 non-Government energy experts affillated with industry, universities, and trade organlzations to evaluate the budget's relevance to long-term energy goals. Responses supported increasing non-nuclear areas, such as conservation and fossil energy research and environmental control, and decreasing allocations for fusion power and flssion reactor research. Specific recommendations were to increase: (1) overall energy budget, (2) non-nuclear prograns, (3) conservation programs, (4) short-term (10 to 15 years) programs, (5) advanced power systems (e.g., gas turbines), (6) coal process development, (7) sol ar heating and cooling, and (B) envil ronmental control; and to decrease: (1) ognetohydrodynami cs (MHD), (2) coal liquefaction demonstrations, (3) solar electric development, and (4) nuclear prograns. Electric energy generation, with its systems 
and storage problems, is not consldered conservation. Individual responses are reproduced. (DCK)

87

CONTENTS OF A GEOTHERMAL LEASE: SOME SUGGESTIDNS. Root, T.E. Nat. Resour. Lawyer: 8: No. 4, 659-668(1976).

Some provisions that might be included in a geothermal lease are suggested wih two caveats in order: (1) the suggestions are not exclusive: a comprehensive lease will contain many more clauses than those suggested; and (2) many problems 111 be resolved only by litigation or Industry practlce, since the geothermal industry is in its legal infancy. It is hoped that a standard or near-standard form will emerge. The response to the potential of geothermal resources has been tworold: (1) regulating leglslation, on both Federal and state levels, has Increased; and (2) the body of knowledge surrounding geothermal resources has been growing rapidly. The literature of geothermal resources has discusaed the state of the technological art, geology or geothermal resource occurrence, economics of geothermal resource development, and legal problems of geothermal resource exploration and development; one major topic awaiting treatment is the environmental aspect of geothermal resource development. This article draws upon both of the responses above, and in suggesting solutions to problens of drafting leases. refers to legislation and geothermal literature when appropriate. (MCW)

88 CALIFORNIA'S ENERGY FUTURE. Morris, D.N. Santa Monica, CA; Rand Corporation (1976). 31p. (P--5616). Publicatlons Dept., Rand Corp., 1700 Main St., Santa Monica, CA 90496. Recommendations for California energy policy are made on the basis of a review of the state's energy sources, patterns of consumption, and projections for both sources and uses. Profected prinary energy use for the year 2000 is 10,310 trillion Btu compared to 5,650 in 1975. With conservation, the projection is for 7,840 trillion Btu, and would involve a shift to less use of petroleum and nuclear energy, an increase in natural gas and geotheraal, and a slight increase in hydroelectric and coal. Recommendations cover oil and gas routes and terminals, of development and deepuater ports, facllities for liquefled natural gas, electricity generation, geothermal and solar research and development, and environmental and institutional issues. The recommendations stress coordination of efforts, centralization of planning, long-range policles, and removal of policles and practices which impede the development of energy supplies. (DCK)

89 GEOTHERHAL HORLD DIRECTORY. Headows, K.F. (comp. and ed.). Glendora, CA; Katherine F. Meadows (1976). 324p

Pert 1 conteins ists of state energy agencies, business and industrial firms, and individuals, both U. S. and worldulde, involved in the development and production of geothermal energy. Parts II and III contain nineteen papers on geothermal energy which were Individually processed for ERDA energy data base. One item, "Economic Implications of Small Geothermal Power Plants,' by T. Meldav was abstracted indIuidually for EAPA. (LBS)

90 GEOTHERMAL ENERGY. Kruger, $P$. (Stanford Unfu., CA). Trans. Am. Nucl. Soc., Suppl.: 23: No: 1, 35-36(1976).

From Conference on environmental aspects of nonconventlonal energy resources: Denver, $\mathrm{CO}$, USA (29 Feb 1976).

GEOTHERMAL RESOURCES; GEOTHERMAL ENERGY;HEAT EXTRACTION; REVIEUS; USES;ENVIRONMENTAL EFFECTS; LEGAL ASPECTS

91 MULTI-PURPOSE 'GEOTHERMAL RESOURCE DEVELOPMENT: AN OVERVIEW. Barnea, J. (UNITAR, New York). Pp 217-221 of Geothermal world directory. Meadows, K.F. (comp. and ed.). Glendora, CA; Katherine F. Meadows (1976).

From United Nations conference; San Francisco, CA, USA (May 1975).

The multi-purpose use of geothermal resources, compared to single purpose development, offers the following advantages: (a) it is more economic and may offer additional social benefits (such as heated swimming pools), (b) it usually allows higher efficlency in energy use, (c) it of ten allous the utilization or associated resources (such as water, minerals, and gases), and (d) it irequentiy minimizes or eliminates envi ronmental problems. The multi-purpose utllization of geothermal resources is possible due to its unique resource characteristics, namely its multi-component and multi-

dimensional features. Geothermal resources may include gaseous, liquid, or solid resources. Its resource structure also includes a heat flow system and storage space. In addition to the direct one-time use of geothermal resource components, there is a re-use potential of some components (such as heat, stean, and water). The possible and economically attractive models of geothermal resource applications will in practice be determined mainiy by three groups of factors: (a) the resource type and size: (b) the economic needs and potential of the area in which the geothermal resources are located; and (c) the Institutional conditions and restraints. (LBS)

INSTITUTIONAL AND ENUIRONMENTAL ASPECTS OF GEOTHERMAL ENERGY DEVELOPMENT. Citron, D.R. (Jet Propulsion Lab., Pasadena, CA). Trans. Am. Nucl. Soc., Suppl.; 23: No. 1, 4143(1976).

From Conference on environmental aspects of nonconventional energy resources; Denver, $\mathrm{CO}$, USA (29 Feb 1976).

GEOTHERMAL ENERGY; ENU IRONMENTAL IMPACTS ; FEASIBILITY STUDIES; LEGAL ASPECTS; ENERGY SOURCE DEVELOPMENT

93 SOCIAL IMPLICATIONS MAY ARISE WITH FUTURE GEOTHERMAL USAGE. Wehlage, E.F. PP 259-262 of Geothermal world directory. Meadows, K.F (comp. and ed.). Glendora, CA; Katherine $F$. Meadows (1976).

From 2. United Natlons symposiun on the development and uses of geothermal resources: San Francisco, CA, USA ( 20 May 1975).

The fullest implication of geothermal heat's effect on society--when it is fully and effectively used--is not being given adequate attention. Geothermal development, especlally for electrical generation, is becoming socially inpacted in the USA. Governmental infiuences evolve. Its effect on the social structure is not only economic in an energy dilema, but people as a society will be increasingly involved. Geothermal's nature is that with nonelectric utilization (required for greatest benefit) population and industry. will be forced to wove causing social pressures in an unknown degree. Better social preparation 18 mandatory. The fullest use of geothermal heat nay dictate drastic reorganization. 
94 GEOTHERMAL ENERGY. Kruger, P. (Stenford UnIv., CA). Annu, Rev. Energy: 1: 159-182(1976).

A general review is given of the major types of geothermal resources, exploration methods, resource extraction technology, utllization technology, and institutional aspects. The development and strategy of a national. geothermal program administered by ERDA and the Department of Interior are briefly discussed. 58 references. (LBS)

95 COMPARATIVE ANALYSIS OF THE 1976 ERDA PLAN AND PROGRAM. Washington, DC; United States Congress (1976). 213p. GPO $\$ 2.80$.

The office of Technology Assessment, in its 1975 analysis of ERDA's initial plan and program, clted two major areas of weakness.. The flrst was ERDA's pursult of technological options, while neglecting consideration of the broader aspects of energy production, delivery, and use. In particular, OTA indicated that the realization of technologlcally established energy optlons may be prevented by nontechnical constraints such as transportation, resource, manpower, and capital avallabllity; public acceptability: and institutlonal. jurisdictional, economic, and environmental compat ibflity. ERDA has made signiflcant progress in this area as reflected in the updated Plan and Program (ERDA-76-1). ERDA has more aggressively interpreted its role in meeting the Nation's energy goals by expanding its efforts to deal with non-technologlcal constraints. It is apparent that ERDA has begun to orlent its Research, Development, and Demonstration program more toward solving energy problems rather than just creating technical options. The second deficlency was found in the emphasis of both the ERDA Plan and Program on optlons directed toward increased energy supply, relative to the programs in enduse demand reductlon. Supply programs were over conservation prograns by a ratio of $49: 1$. ERDA has now increased the role and priority of conservation to the same level as the highest priority supply options in meeting the Nation's near-tern energy needs. In the year since ERDA's formation, domestic production of natural gas declined 6.9 percent and crude oll 4.5 percent. At the sane time, petroleum imports accounted for 37 percent of the Nation's total petroleum consumption in 1975 and are now approaching 40 percent. Achleving energy independence by 1985 has become all but Impossible.

96 ECONOMIC AND ENGINEERING IMPLICATIONS OF THE PROJECT INDEPENDENCE 1985 GEOTHERMAL ENERGY OUTPUT GOAL AND THE ASSOCIATED SENSITIVITY ANALYSIS. Mukhopadhyay, A.K. (Jet Propulsion Lab., Pasadena, CA). Pp 739-746 of Eleventh intersoclety energy conversion englneering conference. Vol. I. New York; American Institute of Chemical Englneers (1976).

The Project Independence 1985 geothermal output goal, viz., 20,000 megawatts (MW) is combined Wh the avallable tine-line data for a typical geothernal energy plent in order to establish requirements, such as, the rate of lease award, exploration, production drilling, plant construction resource expenditure/supply necessary to meet such an adopted goal. Though the specifle time-iline used in the study is based on detalled discussions with federal, state and Industry representatives, time-1ines by their very nature can vary drastically with state and local regulations, the nature of the specific reservole under development and other factors. Similarly, the exploratory and drilling rig efflciencles and the unlt costs assoclated with the various phases of geothermal development depend on today's framework of technologlcal, environmental and economic constralnts. Thus, it is highly imperative to deteraine the sensitivity of the needed rates of development to various technical, economic and Institutional parameters: it is equaliy significant to investigate the sensitivity with respect to variations of the goal magnitude, the goal rate and the goal date from the nominal values set out In Project Independence. A computer program has been written, so that the results of such a sensitivity analysis can be quickly obtalned as printed and plotted output with the least expense.

POTENTIAL NATIONAL BENEFITS OF GEOTHERMAL ELECTRICAL ENERGY PRODUCTION FROM HYDROTHERMAL RESOURCES IN THE WEST. Bloomster, C.H.: Engel, RoL. (Battelle Paclfic Northwest Labs., Richland, WA). Pp 853-859 of Eleventh intersociety energy conversion engl neering conference. Vol. I. New York; American Institute of Chemical Engineers (1976). To evaluate the competitive role of geothermal energy in a predominately nuclear and coal based electric power economy, a computer simulation of the U.S. power econony was employed. The simulation opt Imizes the installation of new generating capacity on a multiregional basis. Thls study included only the hydrothermal resources in the Nest. New geothermal capacity in the West, however, has national impact through reducing the demand and the cost of nuclear and lossil fuels. The potential benefits from geothermal energy are estimated at $\$ 2-\$ 8$ billion in reduced electricity costs. Geothermal energy is estimated to achleve 8-20. percent of the electricity generation in the West $(9,000-$ 17,000 NWe by 1990). The ' most likely scenarlo'i Is the lower values in the above ranges. This scenarlo would save $(1) \$ 11$ bililon in powerplant capital costs, (2) 32 million separative work units, (3) 64,000 tons (58.2 $\times 10^{3}$ tonne) of $\mathrm{U}_{3} \mathrm{O}_{\mathrm{s}}$. and (4) 700 afllion barrels $\left(112 \times 10^{\circ} \mathrm{m}^{3}\right)$ of oll.

98 ELECTRIC UTILITY COMPANIES AND GEOTHERMAL POWER. Pivirotto, D.S. (Jet Propul sion Lab., Pasadena, CA). Pp 843-849 of Eleventh intersoclety energy conversion engineering conference. Vol. I. New York; American Institute of Chemical Englneers (1976).

The electric utility industry is currentiy the primary potential market for geothermal energy. Englneers concerned with the design of geothermal power plants, electric conversion equipment or exploration and devel opment technology must therefore consider utility industry requil rements which may affect such designs. The needs of the electric utility industry as these needs impact the development of geothermal energy are discussed. The electric utility industry, its structure, the forces which influence utility companies and their relationshlp to geothermal energy are described. Considerations necessary to a federal program for geothermal development are presented, and strategy for federal stimulation of utility investment in geothermal energy is suggested. The needs for demonstration of commercial feaslbillty of hydrothermal resources and for reservolr engineering technique development are pointed out. Possibilities are discussed for stimulating utility investment through PInancial incentives, anel loration of Inst I tutional berriers, and technologlcal improvements. 
99 INTERDISCIPLINARY PLANNING FOR GEOTHERMAL DEVELOPMENT AT THE COUNTY LEVEL. Plerson, D.E. Pp 850-852 of Eleventh intersociety energy conversion engineering conference. Vol. I. New York: Anerican Institute of Chemfcal Engl neers (1976).

A National Science Foundation grant to the County of Imperial is funding a study for planning for geothermal development at the county level, the outcomes of which will be a geothermal element of the County General Plan and research methodology for utillzation by other government entities. The reseerch work is beling subcontracted to two universities. The project results must withstand public accountabllity in the form of public hearings, and acceptance by the County Planning Commission and the County Board of Supervisors. The subject areas addressed by the study are: resource assessment, engineering, geography, environment, economics, sociology and political/ legal. A status report of research results is included.

100 GEOTHERMAL STEAM PRICING AT THE GEYSERS, LAKE AND SONOMA COUNTIES, CALIFORNIA.

Dutcher, J.L.: Molr, L.H. (Professional Engineers, San Francisco). pp 786-789 of Eleventh intersoclety energy conversion engineering conference. Vol. I. New York: American Institute of Chemlcal Engineers (1976).

One utility company in the United States produces electricity from geothermal steam. This company buys the steam from several steam producers under contracts with essentially identical rate provisions. These provisions are based on historical fossil-fuel costs and plant efficlency and nuclear generation costs experienced by the utility. A change in the parameters of generation, efficlency, or fuel costs will change the geothermal steam rate. Several changed circumstances are postulated and their effect on the geothermal steam rates considered.

101 PROTECTING THE ENVIRONMENT. McCormack, M.M. (House of Representatives). Pp 49-55 of Encyclopedia of energy. Lapedes, D.N. (ed.). New York: McGraw-Hill Book Company (1976).

The environmental inpacts of producing and ut llizing fossil and nuclear fuels are investigated. The measures applied for keeping these impacts within socially acceptable limits and major legislative approaches to this end are exanined. The effects of producing coal, oil, natural gas, uranlum, ofl shale, tar sands, and geothermal energy are specifically investlgated. Heat energy from these sources can be used directly as process heat by industry to heat and cool bulldings or for conversion into electrlcal and mechanical energy. Common to all of these uses are the environmental effects from burning of fossil fuels or the fissioning of uranium. The environmental aspects of the conversion of heat into mechanical energy and electricity are reviewed. The environmental impacts of hydro power, tidal power, solar power, and wind power are discussed briefly. Measures to control air quality, water quality, land pollution, strip mining, and nuclear power are not without Impacts of thelr own in terms of costs, jobs, or resources. The author concludes that the problem is to balance society's need for energy against the need for a livabie environment, at the same time giving appropriate attention to important economic technical, and social ractors. (MCH)
102 ERDA'S GEOTHERMAL $R$ AND D PROGRAM. Wills, E.H. (Energy Research and Development Administration, Washington, DC). pp 115-128 of Energy technology III: commerclalization. Bethesda, MD; Government Institutes, Inc. (1976).

The objective of ERDA's geothermal energy program is to provide viable energy option by helping to develop and demonstrate the substantial geothermal resources existing in the USA. Three major problem areas are resource uncertainty, technical risks, and institutional impediments. The program strategy is: to reduce resource and reservolr uncertainties; to encourage Industrial development of hydrothermal resources; and to develop technologies for exploiting larger geopressured and hot-dry-rock resources. (LBS)

103 OUERSIGHT HEARINGS ON PUBLIC LAW 93-410: THE GEOTHERMAL ENERGY RESEARCH, DEVELOPMENT AND DEMONSTRATION ACT OF 1974. HEARING BEFORE THE SUBCOMMITTEE ON ENERGY RESEARCH, DEVELOPMENT AND DEMONSTRATION OF THE COMMITIEE ON SCIENCE AND TECHNOLOGY, U.S. HOUSE OF REPRESENTATIVES, NINETY-FOURTH CONGRESS, SECOND SESSION.

Washington, DC; Committee on Science and Technology (1976). 1073p. GPO.

The hearing addresses the comprehensive geothermal program definition submitted by ERDA in October, 1975. This document was developed pursuant to the Geothermal Energy Research, Development and Demonstration Act of 1974 , Public Law 93-410. The U.S. Geological Survey estimates that the evaluated geothermal fields alone contain about 42,000 mu centuries of recoverable electricity - enough to satisfy the needs of 140 cities of 1 million people each for the next 30 years at present consumption rates. The act lays out a broad national program for the commercial development of the geothermal resources of this country. It has four major aspects: (1) it requires that ERDA, in cooperation with the Geological Survey, carry out a proper inventory and assessment of the geothermal resources; (2) it establishes an $R$ and $D$ program with the major objectlve of resolving all the technical problems inhibiting the commercialization of geothermal energy: (3) it requires demonstration of the technological and economical viability of this resource: this legiglation mandates that we have, by 1980,6 to 10 demonstration plants producing electrical power and other energy from a variety of geothermal sources; and (4) the linancing is provided through a farsighted loan guarantee program. The first witness was Dr. John Teem, ERDA, accompanied by Dr. Eric Willis, ERDA; the second witness was Dr. Vincent E. McKelvey, Department of the Interior. Finally, R.D. Ginter, of the NASA Office of Energy Programs, presented the testimony from JPL, under the direction of NASA, on a draft geothermal program definition. The hearing contrasted the JPL document with the ERDA report. (MCW)

104 CRITICAL NATIONAL CHOICE: NEW ENERGY HORI ZONS. . . OR HORIZONTAL DISINTEGRATION. Washington, DC; American. Petroleum Institute (1976). 11p, American Petroleum Inst., 2101 L St., NW, Washingt on, DC 20037.

Some members of Congress want to bar U.S. oll companies from developing non-petroleum energy sources. They have introduced bills that would make oil companies give up any ownership or Interests they may have in other sources of energy. These sources include coal, oll shale, geothermal steam, uranium, and energy from the Sun. The name given to proposals of this kind is "horizontal divestiture.'- Other proposals 
would di smember the present structure of U.S. oll companies, through what is called 'ivertical divestlture." This means restricting individual oil companies to just one segment of the petroleum business--either exploration and production, or transportation, or refining/marketing. All of these proposals are being advanced at the very time the United States is becoming even more dependent on highcost forelgn oil. And more and more of the imported oll is coming from the Arab countries; the very ones that imposed the oil embargo against this nation in 1973-1974. The extent of U.S. rising dependence on imported oll is clear: in mid-February of 1976 , the U.S. Imported more crude oll than any other time in history. The booklet first explains why various oll companies are searching for different forms of energy besides ofl and natural gas. Second, it demonstrates that strong competition exists throughout the energy business today. Entry of oil companies into non-petroleum energy development has, in fact, increased-not reduced--competition.

\section{GEOTHERMAL ENERGY: LEGAL PROBLEMS DF} RESOURCE DEVELOPMENT. Lindsey, M.K.: Supton, P. Stanford, CA; Stanford Environmental Law Society (1976). 152p.

An at tempt is made to describe geothermal resources and the present technology for recovery, assess the true value of this resource and its potential as a source of electrical energy, discuss the law relating to geothermal resource acquisition and development, and suggest alternative means of regulation that would more adequately protect the public interest. While the rocus is generally on Callfornis and, in particular, on the only geothermal area in North Amerlea which is currently producing electricity, the analys is is equally applicable to other areas that are experiencing geothermal development. The ultimate alm of this publication is to give the interested nonspecialist--whether an individual, a public interest group, or a governmental unit--the factual and legal basls necessary for demanding a suitable framework for the rapid recovery of this valuable natural resource. The experiences of the Northern California Power Agency with geothermal energy show that major legal reforms are needed. Leasing preferences for public agencies, royalty rather than cash advance bidding, and antitrust review of geothermal lessees would ensure greater access to geothermal resources by public agencles. (MCW)

106 AUTHORIZING APPROPRIATIONS FOR THE ENERGY RESEARCH AND DEVELOPMENT ADMINISTRATION. CONFERENCE REPORT TO ACCOMPANY H.R. 13350. Washington, DC; House of Representatives (1976). 62p.

The committee of conference, after considering a proposed Senate amendment and Inserting its own amendment, authorlzed the following: (A) for nonnuclear energy research, development, and demonstration of fossil, solar, geothermal, and other forms of energy for energy conservation, and for scientific and technical education, $\$ 1,175,671,000$; (B) for nuclear energy research and development, basic research, space nuclear systems and other technology, uranium enrichment, national security, and related programs, $\$ 5,271,679,000$; and (C) for environmental research and safety, basic energy sciences, program support, and related programs, $\$ 691,795,000$. Specific program breakdowns under each of the above are presented. (MCH)
107 SUMMARY OF SECTION XII: LEGAL AND INSTITUTIONAL ASPECTS. Anderson, D.N. (State Energy Commission, Sacramento, CA) cxxix-cxxxil of Proceedings of the second United Nations symposium on the development and use of geothermal resources. Vol . 1. Berkeley, CA; Unive of Callfornia (1976). In general the papers in this section dealing with legal and institutional aaters covered the more important aspects of the subjects. The history of geothernal law in New zealand, Iceland, Japan, and the United States is presented and compared. Wit hout doubt geothermal legal and Institutional problems are universal in nature: however, some countries are more advanced than others in their solutions to the problems. In addition, numerous peripherial problems are included, such as: water law, definition of the resource, geothermal rights, and preservation of unique geothermal hot springs areas. Some of the papers deal with economic and forecasting nodels.

108 SUMMARY OF SECTION XI: ECONOMIC AND FINANCIAL ASPECTS. Barr, R.C. (Earth Power Corp., Tulsa, OK). pp exxi-cxxuili of Proceedings of the second United Nations symposium on the development and use of geothermal resources. Vol. 1. Berkeley, CA; Univ. of Callfornie (1976).

Capital is a resource more scarce than oll, gas, coal, uranlum, or geothermal energy. The marketplace, if permitted to function, and the efficlent use of scarce capital will assure adequate supplies of energy In varlous forms to the common beriefit of society as a whole. Geothermal energy for electrical power generation is viewed as competitive with conventional fuels as a source of energy. In order to substantlate this view, geothermal utilization must therefore be developed on a scale equivalent to millions of berrels of oll production per day. The data presented in these papers to describe the economics of geothermal energy are generally based on experience from activities in the United States. The economic parameters established for operations in the United states are most likely representative of the highest costs to be encountered because of regulatory and environmental constraints and therefore may be used for conservative worldwide economic analysis. Horld oll prices, the geothermal geologic setting, the means of converting geothermal energy into electricity, and the financial parameters associated with existing and planned additions to electrical generating capacity by the western Unfted States utilities combine to make up the geothermal marketplace in this discussion.

109 GEOTHERMAL ENERGY: PROSPECTS AND LIMITATIONS. Hess, H. Sierra Club Bull e; 61: No. $10,9-12(1976)$.

A gradual withdrawal of geothermal energy will extend 1 ts use and allow future utilization of this resource as more advanced earth-heat extraction concepts are developed. Unless this is done, geothermal energy will supply only small fraction of our energy needs and for a relatively short $t$ ime. A number of countries are already tapping geothermal fields, but the U.S., with two allilion known acres of geothermal flelds, is the largest producer. Leasing of geothermal fields began in 1970 with the Geothermal Steam Act and directions to ERDA to develop a national goal and progran for fiscal-year 1977. Wells are drilled 4000 to 10,000 feet deep to tap el ther stean to turn turbines or hot water to boll a secondary substance. Total known and anticipated resources are estimated to be able 
to produce 153,000 megawatts for 30 years. Site locations are inportant because geothermal energy cannot be transported. Other possibllitles for earth heat energy are zones of superheated, pressurized flulds found in the Gulf coast area and areas of dry hot rock close to the earth's surface in New Mexico.

Environmental difficulties arise because the best locations for geothermal sources are al so those valued and protected by environmentalists for their scenic and cultural quality and their proximity to areas of volcanic activity. The nolse and equipment necessary for driling operations create a heavy industrial atmosphere which is incompatible with scenic lands. An estimated 20 percent of land surface in a developed field is al tered by erosion and siltation. Alr and vegetation are polluted by large emissions of hydrogen sulfite gas; water by drilling muds, brines, and steam

condensates. ( 6 references) (DCK)

110 GEOTHERMAL ENERGY AND ITS USES:

TECHNICAL, ECONOMIC, ENVIRONHENTAL, AND LEGAL ASPECTS. Banwell, C.J. (United Nations, New York). Pp 2257-2267 of Proceedings of the second United Nations symposiue on the develoment and use of geothermal resources. Berkel ey, CA; Univ. of California (1976). Among the many so-called 'new' sources of energy which have been proposed or tested as replacements for the conventional sources (fossil fuels and hydroelectric), geothermal energy is virtually unique as the only al ternative which was al ready cost-competitive with these established sources before the sharp rise in petroleum prices which occurred in 1973. Iaking into account the overali effect of petrol eum prices on the rossil fuel market, and of the probable cost of Increasing the production of cossil fuels from al ternative sources, It appears probable that the cost of electrical energy generated from a typical geothermal field will now be roughly half that from any alternative, including nuclear energy. One effect of this cost margin will undoubtediy be to promote the development of geothermal energy frow fields which formerly looked less promising. At the same time exponding use will lead to improved exploration and development rethods which, in turn, will result in reduced costs. For the Immediate future, lt seems probable that geothernal energy will be more beneficial to certain developing countries than to the industrial world. This is because geothermal energy can be developed economically in relatively small packages, ranging from 10 to $100 \mathrm{HW}$. In this way, the financlal burden of heavy initial capital investment can be avolded, and later growth in demand can be met by plant extensions. For countries with limited Indigenous fuel sources, the savings in fuel import costs can also become very significant. Thus, with $f$ uel ofl at $\$ 10$ per barrel, the annual saving in fuel cost by substituting geothermal power would be over $\$ 7$ million for each 50 ku of net capacity.

\section{TECHNOLOGY FORECAST OF UNITED STATES} GEOTHERMAL ENERGY RESOURCE DEVELOPMENT. Maslan, F.: Gordon, T.J.: Stover, J. (Futures Group, Glastonbury, CT). PP 2409-2419 of Proceedings of the second United Nations sympos lua on the development and use of geothermal resources. Berkeley, CA; Univ. of Callfornie (1976).

This forecast defines the nature of the technology on which this industry depends, the technological impediments which. if uncorrected, alght block its growth, the means avallable to overcome the Impediments, and the range of energy production levels which inight possfbly be expected from this source. A complete relevence tree for geothermal energy technology was $P$ frst constructed, and was followed by designed interviews with industrial and scientiflc authorities. The results of these two steps were analyzed in a series of energy system diagrams synthesizing the overall judgments about technologlcally feasible levels of development, unconstrained by economic and institutional considerations. In the accelerated case, U.S. geothermal electricity capacity results for 1985 are (MWe): vapor, 3500; liquid, 17,000; hot dry rock, 5000; geopressured, 10,000 . The results for the year 2000 are: vapor, 10,000; 11quid, 500,000; hot dry rock, 200,000; geopressured, 54,000. After this analysis we developed an electric utility simulation model of the deciston mechanism involved in the choice and construction of new central-station generating capacity. In effect, this system-dynamics model simulated the introduction of geothermal energy into the utility fuel cholce for the U.S. The model incorporates economics, construction time, rellabllity, fuel avallabllity, environmental factors, and technology. These forecasts simulate the real geothermal energy electriclty capacity development and their results were as follows: for 1985, normal development 7000 MHe, accelerated development 19,500 MHe; for 2000, normal development 188,000 HWe, accelerated development 249,000 MHe.

112 GOVERNMENT ACTIVITY REPORT ON GEDTHERMAL ENERGY IN JAPAN. Sakakura, $S$. (Agency of Industrial Seience and Tech., Tokyo). Pp 24312434 of Proceedings of the second United Nations symposium on the development and use of geothermal resources. Berkeley, CA; Unlv. of Callforni a (1976).

The move to make effectlve use of geothermal energy in Japan is beling accelerated as a reflection of the world ofl crisis. Japan's energy consumption increased fourfold between 1960 and 1974 , and Japan is the second largest user of energy in the non-Communist world. She now fills 73.5 percent of her current energy needs through imported oll. To keep pace with expanding uses of energy, and to reduce dependence on imports, the government of Japan has launched a long-term research and development effort, Project Sunshine, which a ims to develop several Indigenous energy sources including the geothermal. Approxinately $\$ 9$ million (US) has been appropriated for the total Project Sunshine budget for flscal year 1974 , and $\$ 16$ million for fiscal year. 1975. The research and development interests of Project Sunshine include development of direct exploration methods for geothermal energy (to replace the current petroleum-experience methods); development of drilling and neasuring systems approprlate for the heat, pressure, corrosion, and other conditions of geothermal work; development of binary-cycle and combinedcycle equipment for power generation from lowenthalpy sources; Investigation of techniques for extracting energy from hot dry rocks, including eracturing techniques and artificial hot-water systems; experiments with the use of volcanoes as energy sources for power generation; multipurpose uses; and protection of the environment from deleterious effects. Project Sunshine is scheduled through the year 2000 , and 1 ts schedule is divided into terms of 5 to 7 years each, during whlch it is expected that various phases of the development work will be completed. It is hoped that the program w11 culainate in such things as 100-MW dryrock or volcanic power plants. 
RESOURCES IN THE UNITED STATES, 1968 TO 1975.

Koenig, J.B. (GeothermEx, Inc., Berkeley, CA); Anderson, D.N.; Huttrer, G.W. Pp 139-142 of Proceedings of the second United Nations symposium on the development and use of geothermal resources. Vol. 1. Berkeley, CA; Univ. of California (1976).

From 1968 to 1975, exploration for geotheraal resources in the Western United States increased rapidly. The pace accelerated in late 1973 due to the rise in the price of energy. Energy demand and a favorable economic climate should sustain geothermal development In the future. Federal and ste te lands are now becoming avallable, and efforts are being made to speed the leasing programs. Extensive exploration and development are ongoing at The Geyser's and there have been significant discoverles made in the Imperial Valley, California, and at the Valles Caldera, New Mexico. Exploration is continuing at Beowawe and Brady's Hot Springs, Nevada, and Surprise Valley, Callfornia. In addition, exploration has been increased in portions of Utah, Idaho, Oregon, and Arlzona. Discoverles have been sparse, but should improve as land becomes avallable and exploration is expanded. Exploration and utilization technology is advancing, but a greater effort is requlred to meet the demand. Environmental, legal, and institut lonal problems are stili delaying exploration and development; however increased coordination of federal, state, and local government regulatory programs has been proposed and if undertaken could speed development. The federal government is heavily financing research and development, including exploration and utilization technology and solutions to environmental, legal, and institut lonal problems.

114 MULTIPURPOSE GEOTHERMAL RESOURCE DEVELOPMENT: AN OVERVIEW. Barnea, J. (United Nations Inst. Cor Training and Research, New York). Pp 2197-2200 of Proceedings of the second United Nations symposium on the develoment and use of geothermal resources. Berkeley, CA: Univ. of Callfornia (1976).

Three interrelated complexes determine the possible aultipurpose utillzation of a geothermal resource, namely (1) the resource conditions, (2) the reglonal economic conditlons, and ( 3 ) the institutional

conditlons. The resource conditions may allow hundreds of different resource comblnations for multipurpose ut llization. These will depend on the type and size of the resource and its temperature: its water and inineral and gas content; its balneological potential; and nearby related resources as well. A variety or posslble resource combinations a re discussed. The reglonal econonlc conditions are overriding for resource ut llization as most geothermal resources require local utllization. Detalled discussions lead to the conclusion that developed areas with agrlcul ture, Industries, and citles offer the best conditions, whereas rainy and sparsely populated troplcal areas represent the most unfavorable economlc conditlons for multi purpose geothermal projects. Institutional conditions include government regulations at the state and local level: the attitude or geothermal developers such as governments, oll companles, and so on; environnental laws and attitudes; and institutions providing geothermal training and information. It is shown that in almost ail cases of government-owned geothermal projects, the actual control is in the hands of government electricity corporations, explaining the electricity-only utilization of most developed geothermal resources. This attitude
Is shared by most oll companies, and it emerges as a main factor in the U.S. geothermal development. Wider resource information, wore economic studies, and inst Itutional

improvements are proposed.

115 UNITED STATES LAW AS IT AFFECTS

GEOTHERMAL DEVELOPMENT. AIdlin, J.W.

Power Co., Los Angeles). Pp 2353-2357 of

Proceedings of the second United Nations symposium on the development and use of geothernal resources. Berkeley, CA; Univ, of California (1976).

The laws of the United States and of the various states have inhibited the rapld development of geothermal energy. Al though the federal Geothermal steam Act of 1970 becane law in December 1970, it was not unt 11 1974 that compet Itlve lease sales were held on rederal lands, and only now are noncompetitive leases being issued or scheduled for issuance. The many legal requi rements, obstructions, and limitations have made the task of the limited number of persons charged with responsibility to accelerate geothermal development difficult and time consuming. For example, the requirements of the National Environmental Protection Act, the authority exercised by the office of Management and Budget and Internal Revenue Service, the requirements of varlous government agencies, such as the forest Service, have all contributed to the delay. Above all, there has been, until recently, no overriding priority granted to geothermal development. The varlous states have defined geothermal resources in thelr own way and in so doling have in many cases ral sed issues as to the character and ownership of the resource. Such confusion has inhibited development. Local governmental agencies have delayed development by imposing time-consuming, expensive, and Prequentiy unnecessary requilrements relating to environmental matters. A major lack is the absence of adequate means of communication between local and state agencles and Industry as to problems to be resolved.

\section{LAW AND GEOTHERMAL DEVELOPMENT IN NEW}

ZEALAND. Dench, N.D. (MInlstry of Works and Development, Velilington, N.Z.). pp 2359-2362 of Proceedings of the second United Natlons symposium on the development and use of geothermal resources: . Berkeley, CA; Univ. of Callfornia (1976).

While the Geothermal Energy Act 1953 provides for the control of specifically geothermal development in New Zealand, legisiation dealing with the conservation of natural waters, and with orderly land development, Is high on the long 1 ist of laws which must be satisfled, in common with many engineering projects. The Act relates to all energy derived from the carth's natural heat, excluding water at temperatures up to $70^{\circ} \mathrm{C}$. The sole right to exploit the energy is vested in the Crown (effectively the nation), regardless of land ownership. Furthermore, if development involves the payment of compensation to the landowner, the amount should not include any unrealized potentlal benefit of the energy. Specific land areas may be reserved for use by the crown alone. El sewhere, the landouner or the Crown may allow exploration, including drilling, provided certain safety and administrative conditions are net. The right to use geothermal energy (rather than merely to investigate it) is subject to the granting of a ifcense, unless the energy is for domestic purposes and comes from welle less than 61 a deep. The many small users are also exempt from the payment of rental amounting to about 3 US cents/GJ of energy used in excess of $10 \mathrm{TJ} / \mathrm{yr}$. 
There is legal insistence on the technical and environmental adequacy of any development, and the means for policing it.

117 GEOTHERMAL EXPLORATION AND DEVELOPMENT IN THE UNITED STATES: A TAX ANALYSIS UNDER THE INTERNAL REVENUE CODE, Elsenstat, S.M. (Elsenstat and Gottesman, P.C., Attorneys at Law, New York). pp 2369-2372 of Proceedings of the second United Nations symposium on the development and use of geothermal resources. Berkeley, CA; Univ. of California (1976).

Hundreds of millions of dollars are-invested annually by the private sector to explore and develop ofl and gas properties in the U.S. The $r$ isk of such investiments is reduced by the tax benefits of such activities. A significant portion of the cost of drilling and completing the well is deductible from the ordinary incone of the investor: and if production is established, It is subject to depletion (that is, part of the income is tax (ree). Geothermal exploration and development should receive comparable treatment. The Reich and Rowan cases, the only two reported cases relating to geothernal exploration, found that the same favorable tax consequences which result from oll end gas exploration applied to geothernal exploration. The U.S. Internal Revenue Service is st111 challengling the tax treatnent of geothermal exploration. Congress has proposed certain changes in the Internal Revenue code to benefit the geothernal industry. but additional legislation is necessary to clarify the tax treatuent. Once the tax treatment of geothermel exploration and development has been conclusively determined, substantial funds could be deployed to develop geothermal properties. The tax benefits would reduce the risk of the exploration and would also significantly improve the economics of such an investment.

118 PROPERTY SYSTEMS IN GEOTHERMAL RESOURCES: A CRITIQUE AND RECOMMENDATIONS. Franzen, D.E. (Hertzberg, Kaplan, and Kosl ow, Los Angeles). pp 2373-2381 of Proceedings of the second United Nations symposi um on the development and use of geothermal resources. Berkeley, CA; Unive of California (1976).

The incentive pattern facing a developer depends on the rights bundle in the resource. To guarantee that exchange relations can operate to allocate resources to their highest value use, it is necessary that property interests be (1) certain and (2) freely transferable. Even when these elements of 'marketability'. are satisfled, resource nisallocation may still obtain if the development of the resource generates external costs not borne by the developer. In the case of geothermal flelds, external costs in the form of (1) ownership competition for the underlying steam or water, and (2) retrieval costs imposed by exploitation may present developers with false cost alternatives and direct them to exploit the resource at nonoptinally rapid rates. Soclety will be denied the full value product of the energy field. Preexisting legal classifications such as water and oll, when applied to geothermal resources, result in substantial societal loss by falling to provide marketability and-by encouraging overutilization of the resource. Developing statutory law, such as the Federal Geothermal Steam Act, may also be deficient in the same respects. Field development by unitization may, if properly implemented, provide an adequate solution to the external costs problem. Marketability interests can be satisfied by structuring property rights so as to afford owners a determinate share in the underlying energy resource.

119 GEOTHERMAL DEVELOPMENT POLICY FOR AN ISOLATED STATE: THE CASE OF HAWAII. KanIns, R.K. (Univ. of Hawail, Honolulu). pp 23832388 of Proceedings of the second United Nations symposium on the development and use of geothermal resources. Berkeley, CA; Univ. of Californla (1976).

Hawall presents the case of an Industrlalized economy almost completely dependent on imported fossil fuel, but possessing. potential indigenous energy sources. Publicly financed exploration for geothernal resources is under way, and the Haweil state government is considering what actions should be taken to encourage and also regulate the resource should it be economically useful. In determining the level and $k i n d s$ of support to give geothermal development, the state should consider benefits going beyond the substitution of geothermal power for inported oll. These benefits may include: (1) insurance against the interruption of petroleun imports or additional increases in their price: (2) stimulation of local employment; ( 3 ) population decongestion, with encouragement of population growth near geothermal areas, away from Honolulu; and (4) environmental enhancement, with the institution of power production less polluting than burning oil. Methods of approximating the value of these splllover effects are shown using Hawail data as an example.

120 TECHNICAL ASSESSMENT OF THE IMPACT OF GEOPRESSURE DEVELOPMENT IN THE CORPUS CHRISTI AREA OF TEXAS. Kleeman, W.T. (Texas General Land Offlce, Aust (n): Haynes, K.E.; Freeland, T.F. PP 2389-2401 of Proceedings of the second United Nations symposium on the development and use of geothermal resources. Berkeley, CA; Unive of California (1976).

This study is an outgrouth of a four-year ongoing U.S. National Sclence Foundation (RANN) profect on the impact of alternative environmental policies on coastal-zone development in the Corpus Christ 1 area of Texas. In recent years geothermal development has become distinct possibility in the vicinity of the study area due to the identiflication of a belt of geopressured sands in the immediate offshore area. The economic interrelationships between alternative environmental policies and the development of a nearby geothermal energy source are examined. This examination is based on a localized version of the Texas Input-Output Model and on information generated from the environmental policy impact analyses. In addition to the impact on output there are also changes in the rates of migration, expansion, and location of housing, and the location of economic activity.

121 CALIFORNIA'S GEOTHERMAL LANDS: A LEGAL FRAMEWORK FOR RESOURCE DEVELOPMENT. Lindsey, M.K. (Stanford Law School, CA). pp 24032407 of Proceedings of the second United Nations symposium on the development and use of geothermal resources. Berkeley, CA; Univ. of Callfornia (1976).

The state of California has provided comprehensive legal framework for the development of geothermal resources within the state. The scope of the california statute, and prospecting and leasing procedures are reviewed. It is recommended that deficiencies in the state statute be refined to conform to federal standards. (LCL) 
LEGISLATION IN JAPAN. Nakamura, S.; Nakehara, As Iga, H. (Japan Geothermal Energy Asociation, Tokyo). Pp 2421-2429 of Proceedings of the second United Nations symposium on the development and use of geothermal resources. Berkeley, CA; Univ. of Californta (1976).

The method of development of geothermal power, which is recently recelving great attention as a form of domestic underground energy resource, is presented. It is not a mineral, however, so it does not come under the Mining Law; and rights pertaining to the development and usage cannot therefore be based on this law. Geothermal power exists mostly in volcanic and hot spring areas, with prectically the same quality and form as the hot spring. Development is similar to hot spring drilling so rights for possession and usage are obtalned In accordance 1 th the provisions of the Hot Spring Law. Also, many geothermal power areas are within parks of great natural beauty and the development of geothermal power is thereby restricted by the Parks Law. Many geothermal power development areas are also in national lands. Sales and leasing of these lands are mainly to the public or enterprises benefiting the public under the National Properties Law and the National Lands Law. Under the Forestry Law, deforestation is restricted even on private land. In addition, geothermal electric power generation facilities are included as thermal power lacillties under the Electricity Utillty Industry Law. It is now necessary to establish a systematic organization to handle the above problens to promote the development and usage of geothermal power and to stablilize the question of right. For the present, however, a bill is being considered to designate geothermal power development areas and to determine the developers.

\section{LAW OF ICELAND AS IT AFFECTS GEOTHERMAL} DEVELOPMENT. Torfason, H. PP 2435-2437 of Proceedings of the second United Nations symposium on the development and use of geothermal resources. Berkeley, CA; Univ. of Callfornia (1976).

In Iceland, geothermal resources are governed by general rules of the common law of property but also regulated by provlsions of statutory law allowing the state certain control over their development. The right of ownership and use of geothermal resources generally vests in the owner of the land where the resources lie. Accordingly they are largely under private ounership and not necessarily vested in the state unless the state is the owner of the property to which they belong. The depth to which individual ownership of geothermal resources may reach has not been defined by 1 aw. Conflicts between adjolning properties are to be settled by appraisal of their rateable interests in the geothermal field. Geothermal resources may not be separated by sale from the land to which they belong except by permission of the $S$ tate. In case of sale of the resources or of the land the local municipality and the state have a preemptive right of purchase (at market value). The state has a right to expropriate geothermal resources for public purposes, subject to compensation to the owner by constitutional right. In electricity production, the pivotal rule is that a parliamentory concession is required to establish power plants, and development is in fact mostly handled through utility corporations owned by the state and/or major municipalities. In space heating, the policy of the law is to entrust development to municipalities, who may be granted a monopoly to operate geothermal heating systems in defined areas, to the exclusion of other means of heating. Development for other purposes (agricultural, industrial) is not as heavily regulated by statute. The state, acting through the National Energy Authority, has a right to explore geothermal resources wherever situated by drilling or otherwise and generally to supervise their conservation and development.

124 CALIFORNIA GEOTHERMAL RESOURCES: HOW WELL ARE WE DOING. Warren, C. (State of California Leglislature, Sacramento). Pp 24392441 of Proceedings of the second United Nations symposiun on the development and use of geothermal resources. Berkeley, CA; Univ. of Calffornla (1976).

The State of Callfornla is the location of the largest geothermal electrical generation complex in the world. The legal framework which permitted and guided development of this resource on state-owned lands is contained in the Geothermal Resource Act of 1967. An incentive measure based largely on experience gained in regulation of oll and gas developments, the legislation is credited with assisting in the rapid geothermal development at The Geysers. Environmental concerns, institutional barriers such as unequal tax treatment on both the state and federal levels, and the need for streamlining permitting procedures has resulted recently in passage of some far-reaching new energy legis lation Including the Warren-Alquist Act of 1974. The leglsiature is now considering measures to remove some of the remaining legal

disincentives and is revlewing the basic geothermal law to require performance from developers while insuring access to the resource to all able developers.

\section{SOCIAL IMPLICATIONS THAT MAY ARISE WITH} FUTURE GEOTHERMAL USE. Wehlage, E.F. Pp 2443-2445 of Proceedings of the second United Nations symposium on the development and use of geothermal resources. Berkeley, CA: Unive of Callfornia (1976).

The fullest lmplication of geothermal heat's effect on soclety--when it is fully and effectlvely used-is not being given adequate attention. Geothermal development, especially for electrical generation, is becoming socially impeded in the USA. Governmental influences evolve. Its effect on the social structure is not only economic in an energy dillemma, but people as a society $w 111$ be increasingly Involved. Geothermal energy's nature is that with nonelectric utilization (requlred for greatest benefit) population and industry will be forced to move, causing soclal pressures in an unknown degree. Better social preparation-1s mandatory. The fullest uge of geothermal heat may dictate drastic reorganization.

126 LEGAL ASPECTS OF GEOTHERMAL ENERGY DEVELOPMENT. Weinstein, D.; Gordon, T.J.; Masian, F. (Futures Group, Glastonbury, CT). pP 2447-2455 of Proceedings of the second United Nations symposium on the development and use of geothermal resources. Berkeley, CA; Unive of Callfornia (1976).

The legal structure for regulation of geothermal energy development should be logically and explicitiy related to the nature of the resource and the institutional arrangements most appropriate to its development. The legal regime in the United States is, however, not as rationally structured as it might be. It is a product of past and present laws, at state and federal levels, on ining, mineral leasing, mineral disposal, water resource, the environment, and public land. The regulatory structures 
governing exploitation of other natural resources are not entirely appropriate to geothermal development. Recent state and federal legislation attempts to chart anique course for geothermal resource development, but has not completely overcome the legacy of the past; inportant questions concerning ownership and acquisition of rights to geothermal resources have been left unresolved. The legislation addresses the roles of the public and private sectors in geothermal resource development. Private developers have questioned federal and state policies with respect to: avallability of public lands; competltive and noncompetitive bidding systems; rent and royalty structures; lease teras: environmental and land-use regulation; tax treatment; and allocation of regulatory responsibilities. In some of the areas, policymakers should now reconsider earlier decisions; in other areas they should closely monitor future performance to determine whether policy changes are needed.

127 POSSIBLE CONFLICT BETHEEN THE INTERESTS OF TOURISM AND GEOTHERMAL POHER DEVELOPMENT. Wilson, S.H. PP 2457-2466 of Proceedings of the second United Nations symposiun on the development and use of geothermal resources. Berkeley, CA: Unive of California (1976).

The discharges of holes drilled for geothermal prospecting or development may cause, through the lowering of the water table, the decay of local hot-spring activity. So far, the losses in New Zealand have been Geyser Valley, major tourist attraction at Wairakel, two minor areas there, minor hot springs of Kawerau and Broadlands, with a fortunate escape for Walotapu, a major atraction. There have al so been losses through hydroelectric developments, especlally at Orakelkorako, a major tourist attraction, where 75 percent of the hot springs have been flooded. If one defines a 'Thot spring region'" as a locality where hot spring areas of varied attractions can be conveniently visited from one center, then there are only live such regions in the world. Yellowstone National Park is preeminent in the number and size of its geyser basins, but the Rotorua-Taupo region, al though poor in geysers, has the advantages of accessibility at all seasons, assoclation with active volcanism, and a greater varlety of scenery. Any further losses of hot springs in the region, now with four mafor tourist attractions, would be serious. The underground reservoirs of hot water may last under exploitation for only 100 years, perhaps until nuclear fusion energy makes them unnecessary. Hence the fact that losses have been compensated by tourist interest in the bore fleld, and the power developaent, loses its signiflcance, especially as later power developments will not have the same interest. Tourism, even if modified in ways not yet envisaged, can be expected to last as long as the natural springs, perhaps for thousands of years. Serious clashes between tourlst interests and power developments seem to need further consideration only in New Zealand.

128 ECONOMIC AND SOCIAL ASPEECTS OF GEOTHERMAL ENERGY RESOURCE DEVELOPMENT. Maslan, F.: Gordon, T.J.: Deitch, L. (Futures Group, Glastonbury, CT). Pp 2325-2331 of Proceedings of the second United Nations symposium on the development and use of geothermal resources. Berkeley, CA; Univ. of Callfornia (1976).

Development of geothermal energy in the United states will be paced by number of socio-economic impedinents as well as by technological problems. The issues are associated with providing a linancially viable base for exploration and development, assuring a market for geothermal steam or hot water, and accomplishing the required research and development in timely manner. Geothermal development will change the electric utility fuel mix by substituting for nuclear and coal generating plants. Businesses involved in the exploitation of geothermal energy and businesses which can uniquely utilize geothermal resources will be stimulated. Macroeconomic factors will be affected because development of geothermal energy seems likely to curnish 5 to 10 percent of the total U.S. electricity demand by the year 2000 . This level of development will stimulate construction of a national electrical grid. Acceleration of geothermal energy development requires changes in certain marketing, financial, and other institut lonal arrangements. Currently, government regulations overlap and cause delays. Another major problem area is the securing of adequate financing for timely development. The impacts on housing and cities stem from industrialization resulting from the development of the geothermal resource itself and from businesses which can utilize the heat and mineral content of the geothermal tluids. Economic and urban planning benefits will derlve from geothermal space and process heat. Geothermal energy will affect international trade relations; forelgn technological aid and geothermal markets can be expected to develop as early as the late 1970 's.

129 ERDA AUTHORIZATION, FISCAL YEAR 1977. PART IV. BASIC ENERGY SCIENCES. HEARINGS BEFORE THE SUBCOMMITTEE ON ENERGY RESEARCH, DEVELOPMENT AND DEMONSTRATION OF THE COMMITTEE ON SCIENCE AND TECHNOLOGY, U.S. HOUSE OF REPRESENTATIVES, NINETY-FOURTH CONGRESS, SECOND SESSION, FEBRUARY 26, 1976. Washington, DC: Committee on Sclence and Technology (1976). 360p. GPO.

Hearings were held on the 1977 ERDA budget for research activities in materials and nolecular sciences and the significance of ERDA programs to public utilities. ERDA budget requests for basic energy science showed an Increase of $\$ 6.8$ million, or four percent. Changes in direction increased funding for nonnuclear technology, including fossil, solar, geothermal, conservation, and environmental. Funding was to be reduced for fission- and fusion-related research and science base. Dato included program objectives and operating, capital, and construction expenses for specific facilities. Representing ERDA were Dr. Robert L. HIrsch and Dr. James Kane. Dr. Larry Hobart of the American Public Power Association stressed the need for adequate funding of rellability demonstration projects for advanced fuel technologles, such as fuel cells, diesel bottoming cycles, StIrling engines, and improved gas turbines. These offer the potential of core efficient use of conventional fuels, more environmentally acceptable power, and a capacity for smaller-scale equipment. (DCK)

130 HITNESSES FOR OIL: THE CASE AGAINST DISMEMBERMENT . Canes, M.E. ( comp.): Markun, P.M. (ed.). Washington, DC; American Petroleum Insti tute (1976). 300p. \$6.95.

Proposed leglslation would dismember this country's oll compenies in elther of two ways. Some proposals would divide the large integrated companies into separate, singlefunction units. Other proposals would prevent the oll companies-our nation's most experienced energy producers-prom participating in the development of other energy resources. Hearings on these bills by 
both Houses of Congress have brought vigorous dissent from the executives of the petroleum companies. Thelr testimony has been brought together in this volume. Fourteen testimonies included on vertical divestiture are: A View From the Independents; Richard J. Boushka; A View From a Large 0il Company, W.T. Slick, Jr.; A Conmon Form of Industrial Organization, Annon, M. Card; An Economist's Analysis, Michael E. Canes; The Standard O11 Breakup of 1911 and Its Relevance Today, Hastings Hyan, Jr.: Vertical Divestiture: Exploration and Production, L.C. Solleau III; Vertical Divestiture: Refining, Walter R. Pelrson; Competition in Refining, Donald C. O'Hara: Vertlcal Divestiture: Pipelines, Charles J. Waldelich; Plpelines, Divestiture, and Independents, fred F. Steingraber; The Southern Caucus Testifles, J.W. Adams III, C.R. Jackson, Pat Green and J.R. Johnson; A View From a Small Independent Distributor, Robert J. Welsh, Jr.;

Internat Ional Relations and Divestiture, Hilliam P. Tavoulerees; and Divestiture and OPEC, Response to Anthony Sampson, Standard Dil Company of Callfornia. Five testimonies on horizontal divestlture are presented, namely: Developing Alternate Sources of Energy, H.T. Sllck, Jr.; tho Should Devel op Coal: Everybody, C. Howard Hardesty, Jr.; Suggestions for Doubling Our Coal Production, DeWltt $W$. Buchanan; The Know-How to Develop Dil Shale, John E. Kasch; and Drilling Expertise and Geothermal Energy, Carel otte. (MCH)

\section{ENVIRONMENTAL IMPACTS OF GEOTHERMAL} RESOURCE DEVELOPMENT ON COMMERCIAL AGRICULTURE: A CASE STUDY OF LAND USE CONFLICT. Andersen, S.0. (Resources Economlst, San Francisco). pp 1317-1321 of Proceedings of the second United Nations symposium on the development and use of geothermal resources. Vol. 2 . Berkel ey, CA; Univ. of Callfornia (1976).

The environmental imacts from geothermal exploitation are largely linited to the area immediately surrounding the production facilities. This creates the unique altuation where private landowners and associated development companies could concelvabiy bear the full benefits and costs of development with nelther adverse nor beneficial implicatlons to the rest of society. This relationship provides the remarkable opportunity to test the contention that when all costs and benefits are - Internalfzed," maximum social gein is achieved. The changes in resource management which occur as landowners become better informed of Pinancial and environmental implications of geothermal development are investigated. This paper reports on the preliminary research. The probable impact of actions of increasingly well-informed landowners who negotlate for higher lease returns and stronger environmental protection is exanined. First the environmental inplications of geothermal development from the private landowner's perspective are summarlzed, the probable influence on lease provisions is hypothesized, and some of the corporate and social implications of these actions are explored.

132 ERDA AUTHORIZATION, FISCAL YEAR 1977. PART III. GEOTHERMAL. HEARING BEFORE THE SUBCOMMITTEE ON ENERGY RESEARCH, DEVELOPMENT AND DEMJNSTRATION OF THE COMMITTEE ON SCIENCE AND TECHNOLOGY, U.S. HOUSE OF REPRESENTATIVES, NINETY-FOURTH CONGRESS, SECOND SESSION, FEBRUARY 19, 1976. Washington, DC; Committee on Science and Technology (1976). 123p. GPO.

The hearing focused on the proposed budget and progran for the ERDA Geothermal Energy
Divislon and on the adequacy of the proposed activities to implement the leglalative mandates of the Geothermal Research, Development, and Demonstration Act of 1974 , Public Law 93-410. One objective of the law was to establish a comprehensive progran for research, development, demonstration, and commercial demonstration of this important energy resource. Another primary objective of the 1974 Geothermal Energy Act was to streamline and coordinate the splintered jurisdictions of the Federal agencies involved in geothermal energy. A major activity set forth in the Act is a resource inventory and assessment program. In addition, the Act established an $R$ and D program to underpin a demonstration program and analyzed the institutional barriers to commercialization of geothermal energy. The budgetary provisions and the strategy for managing these prograns were examined at the hearing. The legislative history of the act indicates that it was the intent of the committee to have 6 to 10 electrical powerplants of approximately 10 to 40 megawatt capacity on line by the end of Plscal year 1980. Rep. Mike McCormack, presiding chairman of the subcomilttee, stated: - In looking at the proposed $\mathrm{f}$ lscal year 1977 budget, the subcommittee must express its clear concern that this objective appears to be in jeopardy due to the absence of any specifle construction items for geothermal energy demonstration plants. He want to clarify what the differences were between the division request and the Presidential budget submission for demonstration projects.' The witnesses heard on these and other geothermal issues were Dr. Robert L. Hirsch, Dr. Eric H. Hillis, Dr. Vincent E. Mekelvey, and Dr. Richard S. Fiske. ( $\mathrm{MCW}$ )

133 STATE TAXATION OF GEOTHERMAL RESDURCES COMPARED WITH STATE TAXATION OF OTHER ENERGY MINERALS. Wagner, S.C. Washington, DC; Geologlcal Survey (1976). 59p.

Comparisons of state taxation on the energy minerals (coal, oll shale, uranium, oll, and natural ges) to that of geothermal energy in six Western States (Callfornia, New Mexico, Utah, Idaho, Nevada, and Oregon) are given for planning economics of geothermal resource development. Separate sections include: property taxes: severance taxes: corporate franchlse; income and exclse taxes; ofl and gas production or conservation taxes. An appendix of geothermal resources and byproducts definitions 18 Included and taxes charts are arranged by state and by type of tax. (PCS)

134 INSTITUTIONAL BARRIERS TO GEOTHERMAL ENERGY DEVELOPMENT. SECOND REPORT OF THE INSTITUTIONAL BARRIER PANEL TO THE GEOTHERMAL ADVISORY COUNCIL. Washington, DC; Federal Energy Adminlstration (1976). $12 p$.

Recommendations for remedial actions elther through legislative and/or regulatory anendment or by directed agency action are given for three areas of study: delays in issuance of noncompetitive leases; drilling pernit delays; and casual use, burdensome and discriminatory treatment of lessees. Other subjects considered resolved through other avenues were: force majeure clause in the lease agreement; assessment of geothermal resources on Indian Lands; steam price review; redefinition of KGRA and reclassification of noncompetitive lease tracts; limitation of the secretary of Interior's discretion to readjust lease teras and conditions; royalty rebate; and royalty reduction contingencles. (PCS) 
135 INSTITUTIONAL BARRIERS TO GEOTHERMAL ENERGY DEVELOPMENT. A REPORT BY THE INSTITUTIDNAL BARRIER PANEL TO THE GEOTHERMAL ADVISORY COUNCIL. Washingt on, DC; Geothermal Advisory Council (1976). 23p.

Recommendations for solving industry problems in the following areas are glven: federal taxation policy; federal-state utility rate structure policy; federal--state environmental protection assessments; federal-state environmental standards for geothermal pollutants; resource assessment; overlapping lease applications; cash bonus competitive bidding; cumulative acreage limitation; utility uncertainty resupplier's performance; readjustment of terms and conditions of leases; minimum leasehold size linitatlons; work requirements; and decays in the issuance of noncompetitive leases on forest lands. (PCS)

136 GEOTHERMAL ENUIRONMENTAL ADVISORY PANEL. SECOND ANNUAL REPDRT, JULY 1, 1975--JUNE 30 , 1976. Menlo Park, CA; Geological Survey (1976). 6p.

Progress is reported in interagency cooperation for identifying mitigating measures for most environmental problems associated with geothermal development. The major problems that remain relate to preservation of certain unlque geological and geothermal areas and certain delicate ecosystems: areas which are outside the purview of the Panel. (PCS)

137 GEOTHERMAL ENERGY. VOLUME 2. SEARCH PERIOD COVERED: MAY 1975--APRIL 1976. CITATIONS FROM THE NTIS DATA BASE. Smith, M.F. (ed.). Springfield, VA: National Technical Information Service (1976). 298p. (NTIS/PS-76-0463).

Research on all aspects of geothermal energy and its development are contained in this collection. Hot-dry-rock systems, geothermal brines, magma systems, drilling, rock penetration, hydrology, and prospecting are studied. Electric power porduction, space heating, englneering, equipment, materials, corrosion and process economics are al so included. (This updated bibliography contains 190 abstracts, all of which are new entries to the previous edition.)

138 GEOTHERMAL ENERGY. VOLUME 1. SEARCH PERIOD COVERED: 1970--1974. CITATIONS FROM THE ENGINEERING INDEX DATA BASE. Smlth, M.F. (ed.). Springfleld, VA; National Technical Information Service (1976). 251p. (NTIS/PS76/0464).

Studies of worlduide research on geothermal prospecting, reglons and resources are clted. Electric power generation, stean heating, and heat recovery are al so included along with government policies, assessment; development and economics. (Contains 141 abstracts)

139 LAUS, REGULATIONS, AND SOCIAL CONSTRAINTS TO THE DEVELOPHENT OF GEOTHERMAL ENERGY. Washington, DC; Smlthsonlan Science Information Exchange, Inc. (1976). 60p.

A compllation of 57 notices of research projects on geothermal energy development are contalned in this document. The supporting and performing organizations, the investigator( $s$ ), funding data, and a brief description of the project are included. Legal aspects are briefly cited where applicable. (MCW)

140 BENEFITS AND COSTS TO LANDOWNERS FROM GEOTHERMAL RESOURCE LEASE AND DEVELOPMENT.
Andersen, S.0.; Wallace, L.T. Berkeley, CA: Univ. of Callfornia (1976). 27p.

Landowners can gain substantially from geothermal resource lease. The amount of gain is dependent on quality and quantity of resources, $t$ ining of exploration and development, and terms of the lease agreement. Substantlal financlal losses from environnental damage and unfavorable tax treatment are also possible. Environmental effects of geothermal exploration and development can reduce the yield and market price of crops and increase crop protection and other operating costs. The tlming and extent of geothermal activities can reduce the value of land for residential, recreational, and other development and make financing of non-geothermal operations more costly and difficult to obtain. the possible gains from the lease must be balanced against the possible costs to determine if new land use is profitable. In most lease agreements, the landowner must decide how much he is willing to give for each lease concession and which combination of assured payments and potential payments best suits the Individual

circumstances. The landowner may need to invest in preliminary exploration to achleve maximum financial return and to protect his other Interests. It is emphasized that legal advice is necessary for accurate lease interpretation and revision.

141 STATE TAX HANDBOOK AS OF OCTOBER $1,1976$. Chicago: Commerce Clearing House, Inc. (1976). $672 p$. $\$ 8.50$.

The charts in this handbook set forth the tax system of each state and the District of Columbia as of Detober 1, 1976. Here you will find arlef description of the statewide levies, the basis and rates of each tax and the principal payment and return due dates.

Introducing the tax outline for each state is a brief digest of the principal revenue provisions of the state constitution. Here, too, the major features of each state's revenue system are outlined generally. Both corporate and personal income tax information is included.

142 SOME ISSUES REGARDING REGULATORY POLICY, POLITICAL PARTICIPATION, AND SOCIAL IMPLICATIONS OF GEOTHERMAL RESOURCE DEVELOPMENT IN THE IMPERIAL VALLEY. Green, P.S.: Steinberger, M.F. Riverside, $C_{A}$; Univ. of Callfornia (1976). 64p. (PB--256569). NTIS.

In order to delineate social and political issues relating to geothermal development, certain local government officials and community leaders in the Imperial Valley were interviewed on their perceptions of the potential of geothermal resources and regulatory problems Implicit in development. County officials exhibited atrong rellef that they had an overall responsibility for the general welfare of the residents of Inperial County who would be affected by the potential economic, social, and envi ronmental impacts of geothermal development. With little coordination among agencies at higher levels of government, County officials looked upon County regulations and coordination as a positive force that could: (1) minimize the negative impacts of geothermal development, (2) encourage multipurpose utilization or geothermal resources, and (3) improve 1 and use planning within thelr jurisdiction. Recommendations for improving the regulatory process included organizational and procedural changes and amendments to state energy legislation. : Suggestions for improving public Input into the governmental decision making 
process were presented in order to make geothermal regulations a joint effort of commercial developers, public officials, and private citizens.

143 * BENEFITS OF STIMULATING GEOTHERMAL ENERGY DEVELOPMENT WITH TAX AND RESEARCH SUBSIDIES. Knutsen, C.A. Richland, WA: Battelle, Pacific Northwest Labs. (1976). 43p. (BNWL-SA-5934).

A technique is demonstrated for evaluating benefits of subsidies and examples are given for using it to determine the cost-benefit ratio. Examples use two preferential tax treatments as opposed to direct research grants for the high-temperature, low-salinity hydrothermal resources. Results are compared and some conclusions are given. (PCS)

144 LEGAL, INSTITUTIONAL, AND POLITICAL PROBLEMS IN PRODUCING ELECTRIC POWER FROM GEOTHERMAL RESOURCES IN CALIFORNIA. Schuller, C.R.: Schilling, A.H.: Cole, R.J.; Simon, G.D. Seattle; Battelle Human Afralrs Research Centers (1976). 392p.

Non-t echnlcal problems hampering the production of electric power from geothermal resources are identified and possible solutions offered. These problems usually occur when one particlpant in the geothermal process has to deal with another. Laws that shape those interactions are examined in ten major groups: leasing, exploration, reaching agreement for utilization, power plant construction, transmission, financing, environmental reporting, the role of the California Energy Commission, proposed air pollution regulations, and the political econonics of individual counties. (PCS)

145 R AND D IN GENERATION: GIVING PRACTICAL DIRECTION TO DIVERSE VIEWS. RIttenhouse, R.C. Power Eng.: 79: No. 12, 44-51(Dec 1975).

Economic, polltical, environmental, and time restraints challenge utility operations to meet the demands for electric power now and in the future. The most basic datum that needs to be known is the growth rate for the ruture. Costly and unnecessary delays are being experienced by the nuclear industry, even though it is widely known that future power generation wil be 1 rom nuclear and coal. Improvements in plant efriclency and reliability have been major goals of research and development with resulting lower rates (until recently) and greater reliability in electric service. The Electric Power Research Institute was organized In 1973 and its staff has free relgn to develop research in areas that wil prove right for providing the public with lower-cost power in a manner that will have the least environmental impact. Its program has shifted from its orlginal id-and long-term interests to emphasis on inmediate near-term problems. Its overall goal, their time frame, and thelr approximate percentage of funding out of a total EPRI budget guideline of about $\$ 150$ million for 1976 are given. The Energy Research and Development Administration is the fourth member (ut 11 ities, manufacturers, industry organizations) that has jolned to blend technical expertise into powerful new $R$ and $D$ force on power generation. Rad-wastes, clean fuels from coal, the environment, combustion, transmission and distribution, fusion, solar, geothermal, wind, fuel cells, MHD, and communications research programs being conducted in the United States are briefly described. Budgets for each utility, manufacturer, EPRI, and the government agencles are discussed brlefly. (MCW)
146 CALIFORNIA PUBLIC UTILITIES COMMISSION. SIpe, H.T. Geotherm. Energy Mag.: 3: No. 12, 26-27( Dec 1975).

A statement is presented on geotheraal resource utllization in California. At the present $t$ ime, there are $502,000 \mathrm{kil}$ lowatts of geothermal generating capacity in the state of California. This generating capacity Is In 11 units at Paciflc Gas and Electric Company'. Geysers Power Plant in Sonoma County. PG and $E$ has current applications pending before the California Public Utilities Comalsion (PUC) for an additional $406,000 \mathrm{kw}$ from four aore units at The Geysers.

147 ENERGY ALTERNATIVES FOR CALIFORNIA: PATHS TO THE FUTURE. Ahern, W.: Doctor, R.: Harris, H.: Lipson, A.: Morris, D.: Nehring, R. Geotherm. Energy Mag.; 3: No. 11, 24-25(Nov 1975).

CALIFORNIA; ENERGY SUPPLIES; FORECAST ING; POWER POTENTIAL; NUCLEAR ENERGY;GEOTHERMAL ENERGY; GEOTHERMAL RESOURCES ; LEGAL ASPECTS

148 GEOTHERMAL FEDERAL LOAN GUARANTEE PROGRAM (FEDERAL REGISTER). Geotherm. Energy Mag.: 3: No. $11,33-35 ; 37-39$ ( Nov 1975 ).

US ERDA ; F INANCING; REGULAT IONS ; GEOTHERMAL ENERGY; GEOTHERMAL RESOURCES; LOAN GUARANTEES

149 ENGINEERING MANPOHER AND ENERGY NEEDS.

IV. FEDERAL POLICIES HAVE AN IMPACT. BEnson, F.J. (Texas $A$ and $M$ Univ, College station). Chem. Eng. Prog.: 71: No. 11, 43-45(Nov 1975). It is the view of the author that governmental policies with impact on energy supply and demand may have unexpected and disestrous consequences on the energy supply situation, particularly where such policies dictate rapid changes in energy use that are not In the economic interests of those affected. For example, the very low price of natural gas has caused it to be used for very mundane purposes and also has resulted in the cessation of drilling and exploration. Some Federal policles and regulations promote use of some forms of energy or discriminate against other forms for various social reasons. The author says that it seems reasonable for the nation to shift from crude oll and natural gas to coal as the major fossil fuel. Federal pollcies have caused uncertainty regarding investments in capital and technological developments. Risks will not be taken as long as it seems probable that changes in Federal policles may increase the risks or reduce the potential economic galns. The reasonable initial program suggested by the author involves beginning with concerted effort of exploration and driling for petroleum: development of the nation's coal resources accompanled with substantlal coal research; and in a longer range program, the development of solar energy, the nuclear fusion process, geothermal energy, and energy from biological processes. (MCW)

150 (NSF-RA-N-74-246) Uncl ANALYSIS OF THE POTENTIAL USE OF GEOTHERMAL ENERGY FOR POWER GENERATION ALONG THE TEXAS GULF COAST. Wl lson, J.S.; Shepherd, B.P.; Kaurman, S. (Dow Chemical Co., Freeport, Tex. (USA)). 15 Det 1975. 69p. Dep. NT Is $\$ 4.50$.

Three forms of potential geothermal energy may exist In the state of Texas: hot rocks in the Trans Pecos reglon, convection type geothermal water in the Rio Grande Rift basin, and geopressured geothermal water along the 
Gulf Coast. Of these, only the geopressured waters have been verifled. Exploration wells for oll and gas have established the presence of deep hot water deposits along the coastal area, of exist in thick shale and sand beds in the geopressured zone. The most favorable area appears to be at depths of 12,000 to 15,000 feet whe the temperatures range from 300 to $4000 \mathrm{~F}$. Indications are that a series of relatively small, 10 to 50 megawatt, power plants could be located along the coastal plain of Texas. These plants could produce at least 20,000 negawatts and possibly as much as 100,000 megawats under the most favorable conditions. Cost of the power appears to be in the range of 25 to $35 \mathrm{mills}$ per kllowatt hour in 1980 providing the water is saturated ulth natural gas which could be sold to off set some of the cost. If the gas is present, at least 6 billion cublc feet per day of natural gas would be produced. Unit capital investment for such plants would exceed projected costs for nuclear or fossil fueled power plants. Successful development of a demonstration plant with public funds could establish the viablilty of geopressured waters as a source of power and natural gas and encourage private investment to exploit this energy source, should it prove competitive with other sources of electrle power generation.

151 (PB--246568) UnC1 MINERAL LEASING ON INDIAN LANDS: REPORT TO THE FEDERAL TRADE COMMISSION. Dick, J. (Federal Trade Commission, Hashington, D.C. (USA). Bureau of Competition). Oct 1975. 241p. (FTC-7510003-ML/IL). NTIS $\$ 8.00$.

This report covers past and present leasing policies for Indian lands, the statutory and regulatory framework, and an evaluation of leasing policies--particularly their effect on competition. It contains a series of recommendations designed to safeguard the interests of the Indlans and otherwise ald the mineral leasing program in achieving its primary objectlves.

152 (PB--246663) UnC1 STAFF REPORT TO THE FEDERAL TRADE COKMISSION ON FEDERAL ENERGY LAND POLICY: EFFICIENCY, REVENUE, AND COHPETITION. (Federal Trade Comisston, Washington, D.C. (USA)). Oct 1975. 970p. (FTC- $7510003-$ FELP). NTIS $\$ 23.75$.

Past land disposal policies, economic and technological conditions relevant to the cholce of a leasing approach, and the general direction and effectiveness of pollcy for each of the following fuel areas are discussed: offshore oll and gas, onshore oil and gas, oll shale, coal, uranium, and geotherwal energy sources.

153 (PB--250636) UnCl AN ANALYSIS OF THE ERDA PLAN AND PROGRAM. (orfice of Technology Assessment (U.S. Congress), Washington, D.C.). Det 1975. 330p. (OTA-E-12). NTIS $\$ 10.00$. An analysis is given of the energy research and development programs of the Energy Research and Development Administration (ERDA). The analysis was performed primarlly by task groups assembled to cover each of ERDA's major programmatic areas: (1) fossil energy: (2) nuclear energy; ( 3 ) solar, geothermal, and advanced technologles; (4) conservation; and (5) envi ronment and heal th. Since the ERDA plans reflect the President's view of national energy RandD polley, they will in large measure determine the broader options for our future national energy policy; this assessment is intended to provide the Congress with much of the background information necessary for an effective analysis of the ERDA programs.

154 DEVELOPMENT OF THE NATION'S GEOTHERMAL ENERGY RESOURCES. II. Kruger, P. (DIV. of Geothermal Energy, (ERDA), Hashington, DC). Aware: No. 61; 8-13( Det 1975).

GEÓTHERMAL ENERGY;RESEARCH PROGRAMS: LEGISLATION; US ERDA;ENVIRONMENTAL EFFECTS; ECONOMICS;REGULATIONS;USA; GEYSERS GEOTHERMAL FIELD;EXPLORATION;ELECTRIC PONER;PLANNING

155 ENERGY ANALYSIS AND PUBLIC POLICY. Gilliland, M.W. (Unlv. of Oklahoma, Norman). Sclence; 189: No. 4208, 1051-1056(26 Sep 1975).

ENERGY POLICY;ECONOHIC POLICY;NET ENERGY; ENVIRONMENTAL EFFECTS; MATERI ALS ; ENERGY SOURCES; ECOLOGY;MINERALS; COST BENEFIT ANALYSIS; GEOTHERMAL ENERGY;SYSTEMS ANALYSIS

156 (CONF-750720--, pp 59-86) GEOTHERMAL ENERGY RESOURCES. SeP 1975.

From Conference on the magnltude and deployment schedule of energy resources: Portland, Oregon, USA ( 21 Jul 1975).

Magnitude and deployment schedule of energy resources.

Geothermal energy may be considered to be the thermal energy contalned in the upper $10 \mathrm{~km}$ of the earth's crust, which has a mean temperature gradient between 20 to $30^{\circ} \mathrm{C} / \mathrm{km}$, mean emissive heat flux or about $1.5 \mathrm{\mu cal} /$ $\mathrm{cm}^{2} s e c$, and heat content above $15^{\circ} \mathrm{C}$ of some 3 $\times 1026$ cal, of which about $6 \times 10^{24} \mathrm{cal}$ is under the United States. Thls resource base is equivalent to the heat content of $8 \times 1014$ netric tons of coal or $5 \times 10: \mathrm{kWh}$, representing about 375,000 times the lorecasted U.S. total electric power production for the year 1985. Unfortunately, geothermal heat in the outer $10 \mathrm{~km}$ of the earth's crust is too diffuse to be exploitable as an energy resource on a worlduide basis. Resources sultable for commercial exploitation may be defined as localized geologic deposits of heat concentrated at attainable depths, in confined volumes, and at sufficient temperatures for Intended utilization. Al though geothermal resources have been developed largely for generation of electric power, utillzation of geothermal resources for non-electrical purposes such as space or industrial heating, desalination of water, and mineral recovery may be of great value in conserving fossil and nuclear fuels. Environmental inpacts of geothermal energy are discussed. Legal problems associated with geothermal resources vary frov state to state. Three subgroup papers include: Wet and Dry Stean Systems, by David L. Willians: Hot Dry Rock Systems, by William E. Brigham: and Geopressured Systems, by Myron Dorfman. A Review of Geothermal Energy Resources was presented by Geoffrey Robson. (MCW)

157 ADMINISTRATIVE REQUIREMENTS FOR DEVELOPMENT OF GEOTHERMAL RESOURCES. Lyons, T. Geotherm. Energy Mag.; 3: No. 9, 1625( Sep 1975 ).

OREGON; GEOTHERMAL RESOURCES; LEGAL ASPECTS; LAND LEASING

158 ENERGY CHOICES AND PUBLIC POLICY. Fisher, J.L. (United States House of Representatives, Washington, DC). J. Air Pollut. Control Assoc.; 25: No. 9, 910-912(Sep 1975).

It is suggested that the U.S. needs a broad statement of energy goals to go along with the 
economic goals established in the Enployment Act of 1946, the Full Employment Act so called, and to go aiong with the environmental goals stated in the National Environmental Policy Act of 1969, setting up the Councli on Environmental Qual 1 ty, the environmental Impact statements, and the rest. The energy goals for the nation should include these: (1) low-cost, low-price rellable energy supply: (2) environmental protection: (3) national security; (4) energy conservation: (5) an efficlent, competitive energy industry: ( 6 ) some protection against dislocations resulting from energy shifts, retraining for miners, regional development programs, unemployment compensation, and the rest; and ( 7 ) vigorous, Imaglinative $R$ and D prograns. (auth)

159 (JPL--5040-6(Vol.1)) . UnCl PROGRAM DEFINITION FOR THE DEVELOPMENT OF GEOTHERMAL ENERGY. VOLUME I. BACKGROUND AND PROGRAM DEFINITION SUMMARY. (Jet Propulsion Lab., Pasadena, Callf. (USA)). 29 Aug 1975. Contract NAS7-100. 57p. Jet Propulsion Lab., Pasadena, CA.

The research program defined, with its supporting rationale, includes proposed rederal government actions to facilitete a significant acceleration in the commercial utilization of the Nation's valuable geothermal eniergy resources in an environmentally acceptable manner. (MOW)

160 (JPL--5040-6(Vol.2)) Unel PRDGRAM DEFINITION FOR THE DEVELOPMENT OF GEOTHERMAL ENERGY. VOLUME II. PROGRAM DEFINITION DEVELOPMENT RATIONALE AND SUBPROGRAM

DESCRIPTIONS. (Jet Propulsion Lab.. Pasadena, Calif. (USA)). 29 Aug 1975. Contract NAS7100. 195p. Jet Propul sion Lab., Pasadena, CA.

The purpose of this study is to glve. comprehensive progran definitjon of an integrated effort and commitaent for effectively developing geothermal energy resources. A problen analysis discussion is given along with program development suggestions. Subprograms such as resource explorat Ion, utilization, research and development, community planning, and policy analysis are described in detail. (Mow)

161 (JPL-5040-6(Vol.3)) UnCl PROGRAM DEFINITION FOR THE DEVELOPMENT OF GEOTHERMAL ENERGY. VOLUME III. APPENDIXES. (Jet Propulsion Lab., Pasadena, Callf (USA)) 29
Aug 1975. Contract NAS7-100. 389P. Jet Propulsion Lab., Pasadena, CA.

The following appendixes are given: (1) Implication of the 1985 goel and updated sensitivity analysis, (2) geothermal development timelines, (3) leasing and exploration, (4) research and development, (5) electric utilities, (6) nonelectric geothermal market; ( 7 ) geopressurlzed resource $R$ and $D_{1}$ (8) community planning, (9) summary of ERDA patent pol icy relevant to geothermal energy, (10) factors affecting the development of known geothermal prospects, (11) environmental laws and regulations, (12) elementary treatment of economics of geothermal power productlon, (13) conversion cycle analysis, (14) projection of at talnable geothermal energy development and use, and (14) geothermal energy, research, development, and demonstration act of 1974 . Separate abstracts were prepared for each appendix. (MOW)

162 (JPL-5040-6(Vol .3), PP 29p, App. C) LEASING AND EXPLORATION. 29 AUg 1975.
Program definition for the developaent of geothermal energy. Vol. III. Appendixes. This appendix sets forth the analysis and information used in deriving the recommendations (presented in Volune II) to ald the exploration and assessment of geothermal resources. The following subjects are discussed: leasing acreage requilements, avallability and status of land for leasing, capital requirements for exploration, Income to Pederal government $t$ rom geothermal development, exploration Industry status and attitudes, governmental attitudes, and nonrecommended actions. It should be noted that the calculations were based on assumed goals of 8,000 MHe by 1985 and 100,000 mWe by the year 2000. ( $\mathrm{HOW}$ )

163 (JPL--5040-6(V01.3), PP 48p, APP. E) ELECTRIC UTILITIES. 29 Aug 1975.

Program definition for the development of geothermal energy. Vol. III. Appendixes.

A discussion of electric utility companies, their structure, the forces that influence them, and their relationship to geothermal energy is given, based on interviews with utility and financial institution executives. (MOW)

164 (JPL- $5040-6(\mathrm{Vol} .3)$, PP 18p, APp. H) COMMUNITY PLANNING. 29 Aug 1975.

Program definition for the development of geothermal energy. Vol. III. Appendixes.

The results of aerles of interviews designed to obtain the views of the community on the issues considered critical to their wellbeing is presented. These views help form the basis for program definition recommendations. (MOW)

165 (JPL-5040-6(Vol.3), PP 2P, App. I) SUMMARY OF ERDA PATENT POLICY RELEVANT TO GEOTHERMAL ENERGY. 29 AUg 1975.

Program definition for the development of geothermal energy. Vol. III. Appendixes.

This appendix provides background information on patent policy as it pertains to the course of action, rationale, and recommendatlons presented in Vol. II of the program plan. (mow)

166 (JPL-5040-6(Vol.3), Pp 31 p, App. K) ENVIRONMENTAL LAUS AND REGULATIONS. 29 RUg 1975.

Progran definition for the developaent of geothermal energy. Vol. III. Appendixes.

Thls appendix exanines the pertinent aspects of various environmentel laws and regulations that affect geothermal development. (HOW)

167 (JPL-5040-6(Vol .3), pp 11p, App. 0) GEOTHERMAL ENERGY RESEARCH, DEVELOPMENT, AND DEMONSTRATION ACT OF 1974. 29 Aug 1975. Program definition for the development of geothermal energy. Vol. III. Appendixes.

This appendix consists entirely of a copy of the Act. (MOW)

168 GEOTHERMAL RESOURCES OPERATIONAL (GRO) ORDER NO. 4 FOR CENTRAL AND UESTERN REGIONS. Fed. Reglst. (Hash., D.C.): 40: No. 159, 3442734431 ( 14 Aug 1975).

Regulations are lssued by the U.S.

Department of the Interlor in order to provide general environmental protection requirements for these regions. The regulat lons cover land use and reclamation: pollution prevention, including liquid disposal, solld waste 
disposal, and air quality; fire prevention; slope stabllity and erosion control: pollution inspections: disposal of fluids in injection wells: and several other topics. These regulations becane effective as of $8 / 1 / 75$.

169 GEOTHERMAL POWER: STRANGLED BY RED TAPE. Atchison, S. Bus. Heek; 68-69(11 Aug 1975). A commentary is given on problems faced by Industry in seek Ing to develop geothermal resources. The problems briefly discussed include government roadblocks, tax problems, and classiflcation of geothermal resources. Corrective actions by Congress are suggested.

170 DEVELOPMENT OF THE NATION'S GEOTHERMAL ENERGY RESOURCES. Kruger, P. (Energy Research and Development Administration, Hashington, DC). Geotherm. Energy Mag : ; : No. 8, 25-27(Aug 1975).

From 2: energy technology conference: Hashingt on, DC ( 12 May 1975).

GEOTHERMAL ENERGY : GEOTHERMAL RESOURCES; USA; FORECAST ING; RESEARCH PROGRAMS; GEOTHERMAL EXPLORATION; REVIEWS ; LEGAL ASPECTS; GOVERNKENT POLICIES

171 STATE POLICY CONSIDERATIONS FOR GEOTHERMAL DEVELOPMENT IN HAWAII - Grabbe, E.M.: Kanins, R.M. Geothern. Energy Mag.: 3: No. 7, 5-9; 11-13( Jul 1975).

HAWAII; PLANNING;GOVERNMENT POLICIES; GEOTHERMAL RESQURCES; WELL DRILLING: ENVIRONMENTAL IMPACTS;ELECTRIC POWER; USES; ENERGY POLICY

172 SENATE JUDICIARY COMMITTEE HB 2040: APRIL 30,1975 , OREGON. Hook, J.H. Geotherm. Energy Mag.: 3: No. 7, 45(Jul 1975). OREGON : HEARINGS ; GEOTHERMAL ENERGY ;USES;SPACE HEATING: DISTRICT HEATING;ELECTRIC POWER: GEOTHERMAL RESOURCES; LEGISLATION

173 (ANCR--1214) UnCl NATI ONAL PROGRAM DEFINITION STUDY FOR THE NON-ELECTRICAL UTILIZATION OF GEOTHERKAL ENERGY. Kunze, J.F.: Richardson, A.S. (Aerojet Nuclear Co., Idaho Falls, I daho (USA). Idaho National Engl neering Lab.). Jun 1975. Contract AT(10-1)-1375. 106p. DeP. NTIS $\$ 5.45$.

RESEARCH PRQGRAMS ; PLANNING ; GEOTHERMAL ENERGY; USES;ENERGY DEMAND;SPACE HEATING;REFRI GERATION; PROCESSING; AGRICULTURE; ECONOYICS ; MARKET; FORECASTING; DISTRICT HEATING;US ERDA;HEATING

174 RECENT GEOTHERMAL DEVELOPMENTS IN COLORADO. Pearl, R.H. Geotherm. Energy Mag -: 3: No. 6, 45-47(Jun 1975). COLORADO;GEOTHERMAL RESOURCES; LAND LEASING; PUBLIC LANDS :LEGISLATION:THERMAL WATERS

175 (NP--20699) FEDERAL ORGANIZATION FOR NONNUCLEAR ENERGY RESEARCH AND DEVELOPMENT ACTIUITIES OF DEPARTMENTS AND AGENCIES OTHER THAN ERDA: FY 1976. Bates, D.M. (Library of Congress, Washington, DC (USA). Congressional Research Service). 30 May 1975. 90p. TIC.

The purpose of this report is to sumarize the activities of Federal departments and agencles, other than the Energy Research and Development Agency (ERDA), in energy $R$ and $D$. Approxinately $\$ 2.115$ bllilon will be spent in fiscal year 1976 for Federal energy $R$ and $D$ by these departments and agencies: ERDA: Nuclear Regulatory Comission (NRC): Environaental Protection Agency: Department of the Interior;
National Sclence Foundation; Departments of Transportation, Defense, Agriculture, and Commerce; and the Natlonal Aeronautics and Space Administration. The $R$ and $D$ efforts w11 be directed toward $f$ ive progran areas: fossil energy (coal, oll, gas, and shale), solar and geotheral, conservation, nuclear energy, and environmental control. Research support programs of the energy $R$ and $D$ prograns will fund basic research and studles of environmental effects. Information, provided for each department and agency except ERDA, includes an ldentification of the units with princlpal energy $R$ and $D$ responsiblities, anticipated energy $R$ and $D$ lunding, and program area detalls. Because the emphasis of this report is on non-nuclear energy, the NRC is covered briefly. Although the Federal Energy Administration is not 11 sted as an agency with a direct energy $R$ and $D$ program, information is presented on 1 ts $R$ and D progran. (BYB)

176 SELF-SUFFICIENCY IN ENERGY. Marshall, H. Atom (London); No. 223, 62-66 (May 1975). United KIngdom. ENERGY SUPPLIES; PLANNING; ENERGY SHORTAGES; MATERIALS ; FOOD; ENERGY SOURCES : ENERGY POLICY;UNITED KINGDOM; MARKET; NUCLEAR POWER PLANTS;NORTH SEA; SGHWR REACT OR;ENERGY CONSERVAT ION ; PETROLEUM; COAL; GEOTHERMAL ENERGY; TIDAL POWER; TOTAL ENERGY SYSTEMS

177 SOME REFLECTIONS ON THE HISTORY OF THE UNITED NATIONS AND U.S. GOVERNMENT GEOTHERMAL ACTIVITIES. Barnea, J. Geotherm. Energy Mag.: 3: No. 5, 16-18( May 1975). UNITED NATIONS; US ORGANIZATIONS; USA; GOVERNMENT POLICIES ; ENERGY POLICY; GEOTHERMAL RESOURCES ; GEOTHERMAL EXPLORATION ; MEET INGS ; INTERNAT I ONAL ORGANIZATI ONS; REVIEWS ; GEOTHERMAL ENERGY

178 PUBLIC INTEREST VS. PRIVATE PARTISANSHIP IN GEOTHERMAL DEVELOPMENT • Bowen, R.G. (Consulting Geologlst, Portland, oR). Geotherm. Energy Mag.: 3: No. 5, 87-88( May 1975 ).

GEOTHERMAL ENERGY;GEOTHERMAL RESOURCES; HEARINGS : PLANNING ;ECONOMIC DEVELOPMENT: ENVIRONMENT; PRESERVAT ION ; ENERGY SOURCE DEVELOPMENT

179 MAXIMUM AND TIMELY COMMERCIAL DEVELOPMENT OF DOMESTIC GEDTHERMAL ENERGY. QUillen, J.H. Geotherm. Energy Mag.; 3: No. 5, 28-31( May 1975 ).

GEOTHERMAL ENERGY; PROJECT INDEPENDENCE; US ERDA; RESERVES; RESEARCH PROGRAMS ; GEOTHERMAL RESOURCES ; LEGAL ASPECTS ; LAND LEASING; PUBLIC LANDS ; REGULAT I ONS : LEGISLAT ION

180 REDUCING THE RISKS IN GEOTHERMAL

EXPLORATION: A TAX UPDATE. Eisenstat, S.M. Geotherm. Energy Mag.; 3: No. 5, 93-94(May 1975).

GEOTHERMAL EXPLORATION;LEGISLATION: GEOTHERMAL RESOURCES ; TAXES ; PRODUCT ION.

181 GEOTHERMAL EXPLORATION: STRATEGY AND BUDGETING. Barr, R.C. Geotherm. Energy Mag.; 3: No. 5, 39-41( May 1975).

GEOTHERMAL EXPLORATION;BUDGETS; WELL DRILLING; LAND LEASING;SITE SELECTION; GEOPHYSICAL SURVEYS: COST

182 1974: THE GEOTHERMAL YEAR IN RETROSPECT. Wehlage, E.F. : Trans., Int. Soc. Geothern. Eng.: 1: No. 2, S.7409.1-5.7409.7( May 1975). 
Development problems and outlook. GEOTHERMAL ENERGY;ELECTRIC POWER; REVIEWS; USA;KROV MACHINE; BINARY-FLUID SYSTEMS; STEAM TURBINES;LEGAL ASPECTS; ENVIRONMENTAL EFFECTS; GEOTHERMAL RESOURCES

183 U.S. TAXES ON ENERGY RESOURCES. Brannon, G.M. (Georgetown Univ., Hashington, DC). Am. Econ. Rev.; 65: No. 2, 397-406( May 1975).

From Elghty-Seventh Annual Meeting of the American Economic Association; San Franclsco, CA (28 Dec 1974).

Project Independence should be designed to accept oll Imports, bulld up reserves, and guarantee losses to producers of substitutes, rather than becoming another protective tariff wth percentage depletion allowances and deductions of Intanglbles on successful wells. Contrary to clains, lower income taxes are not producing a reserve, which could be provided through direct purchase of crude for storage or by payment for In situ reserves. Risks are better avolded through loss guarantees, and integrated corporate tax rate reduction is preferable to selective politically controlled rellef. Revised bidding procedures on public lands would correct the overdrilling trend that has resulted from current land-ownership rules. Low electricity prices and over-use of resources have resulted from the unnecessary undertaxing of public utilities. Property and exclse taxes, import quotas, prorationing, environmental controls, and natural gas price regulations have all played heavy part in the past tax structure. Current issues revolve around price controls, windfall taxes, income distribution, and resource llocatlons. Future pollcies will need to address the concepts of zero imports, balanced reserves, and reduced consumption. U.S. consumers should not be deprived of the beneflts of reduced world ofl prices in the future. This would mean keeping the U.S. In the world market while economlcally developing substitutes. (24 references) (DCK)

184 (PB--246241) UnC1 A TECHNOLOGY ASSESSMENT OF GEOTHERMAL ENERGY RESOURCE DEVELOPMENT. Gordon, T.J.; Maslan, F.; Deitch, L. (Futures Group, Glastonbury, Conn. (USA)). 15 Apr 1975. Contract NSF-C836. 563 . NTIS $\$ 13.50$.

Geothermal energy, energy derived from the intrinsic heat of the earth may become an important element of the energy inventory of the United States and the world in the next few decades. This report deals with some potential uses of geothermal energy in the United States, evaluates systems and makes recommendations for future applications. Speclelcally the objectives of this study were to: (1) Identify potential constraints to the development of geothermal power: (2) determine feaslbility; (3) determine its social, political, economic and environmental impacts in this country; and (4) provide input to the pollcy process regarding geothermal energy.

185 (PB--243467/8ST) UnC1 STATE POLICY CONSIDERATIONS FOR GEOTHERMAL DEVELOPMENT IN HAWAII, Grabbe, E.M.; Kamins, R.M. (Hawali State Dept. of Planning and Economic

Development, Honolulu (USA) ). Apr 1975. 24p. NTIS $\$ 3.25$.

This is a brief background report that outlines the varlous pollcy options open to Hawali in developing its geothermal energy resources. Topics that are addressed Included: uses of the resource; outcores of exploration and development; constralnts on geothermal drilling In Hawall; State pollcles toward geothermal drilling and development; and, roles of state and county government in geothermal development.

186 (UCID--16807) UnCl REGULATORY ASPECTS OF GEOTHERMAL ENERGY DEVELOPMENT IN THE SALTON SEA/IMPERIAL VALLEY AREA. Tonnessen, $K$. (Callfornia Univ., Livermore (USA). Lawrence Livermore Lab.). Apr 1975. Contract W-7405eng-48. 26p. Dep. NTIS $\$ 4.00$.

GEOTHERMAL RESOURCES ; REGULATI DNS ; GOVERNMENT POLICIES; GEOTHERHAL ENERGY ; IMPERIAL VALLEY; SALTON SEA;LAND LEASING;US ORGANIZATIONS: ENVIRONMENTAL PROTECTION AGENCY

187 NSF/RANN FY 1975 PROGRAM FOR GEOTHERMAL RESOURCES RESEARCH AND TECHNOLOGY. Kruger, P. (Nat 1. Scl. Foundation, Washington, DC). Geotherm. Energy Kag.: 3: No. 4, 15-20(Apr 1975).

RESEARCH - PROGRAMS ; NATIONAL SCIENCE FOUNDATION ; GEOTHERMAL ENERGY; GEOTHERMAL EXPLORATION;WELL DRILLING;ENGINEERING; GEOTHERMAL WELLS; RESERVES ; GEOTHERMAL ENERGY CONVERSION; EXPLOITATION; LEGAL ASPECTS; ENUIRONMENTAL EFFECTS

188 ENVIRONMENTAL IMPACT OF A GEOTHERMAL POWER PLANT. Axtmann, R.C. (Princeton Univ.. NJ). Sclence; 187: No. 4179, 795803( 7 Mar 1975 ).

Wai rakei geothermal fleld. HAIRAKEI GEOTHERMAL FIELD; GEOTHERHAL POWER PLANTS; ENVIRONMENTAL IMPACTS;AIR POLLUTION; WATER POLLUTION ; THERMAL EFFLUENTS ; THERMAL POLLUTION; HYDROGEN SULFIDES;CARBON DIOXIDE;ARSENIC: MERCURY

189 (TID--26866) UnCI REPORT TO THE CONGRESS. PROBLEMS IN IDENTIFYING, DEVELOPING, AND USING GEOTHERMAL RESOURCES. (Department of the Interlor, Hashington, D.C. (USA)). 6 Mar 1975. 26p. Dep. NTIS $\$ 7.00$. GEOTHERMAL RESOURCES; LEGISLATION; US DRGANI 2ATIONS; LAND LEASING; POWER GENERATION; GEOTHERMAL ENERGY;RESEARCH PROGRAMS; BRINES; DESALI NAT ION; REVIEWS ; FRESH WATER;PRODUCTION; ELECTRIC POWER

190 (NP--20694) REPORT TO THE CONGRESS: PROBLEMS IN IDENTIFYING, DEVELDPING, AND USING GEOTHERMAL RESOURCES. (General Accounting Office, Washlngton, D.C. (USA)). Mar 1975. 78p. TIC.

The problems related to the Identification, technologlcal development, and use of geothermal resources are revlewed, and an assessment is made of the potential and progress of developing these resources as a source of both weter and energy. Three government agencies--the National Seience Foundation, the Department of the Interior, and the Atomic Energy Commissi on-have been involved in geothermal activities. The Federal budget for FY 1975 requested about $\$ 49$ nillion for geothermal exploration, research, and development. It is difficult to determine the potential for large scale geothermal power generation because of: 1) a lack of information on the extent and locations of resources; and 2 ) unsolved technological and environmental problems. Est Imates of possible electric power that could be generated from geothermal resources in the U.S. by 1985 range from 4,000 to 132,000 megawat ts. The geothermal leasing program, under the U.S. Geological Survey, has not proceeded as rapidly as expected, due to lack of knowledge on characteristics of resources, early state of 
technology, and lack of information used in classifying resources. The Bureau of Reclamation is heading a program in Imperial Valley, California, for producing 10,500 megawatts of power and $2.5 \mathrm{mill}$ ilon acre-feet of fresh water a year from geothermal brines. Several recomendations are made to the Secretary of the Interior to Improve geothermal resource development. (BYB)

\section{1 (PB--244863) UnC1 AN ANALYSIS} IDENTIFYING ISSUES IN THE FISCAL YEAR 1976 ERDA BUDGET. (DFfice of Technol ogy Assessment (U.S. Congress), Hashington, D.C.). Mar 1975. 101p. NTIS \$5.25.

The report, prepared with the assistance of an ad hoc OTA Energy Panel, appraises the relative levels of funding of various programs embodied in the Fiscal Year 1976 budget of the Energy Research and Development Administration (ERDA), and Identifies major I ssues involving future energy problems. Areas examined include fosstl fuel research: nuclear energy research: solar, geothermal, and advanced energy systems; conservation and energy productivity; and environmental impacts.

192 HAWAII GEOTHERMAL PROJECT. Kamins, R.M. (Univ. of Hawali, Honolulu). Geotherm. Energy Mag.: 3: No. 3, 49-53(Mar 1975). HAWAI I MAGMA SYSTEMS; GEOTHERKAL RESOURCES; GEOTHERMAL EXPLORATION:RESEARCH PRDGRAMS: GEOPHYSI CAL SURVEYS; VOLCANIC REGIONS; ENGINEERING; MANAGEMENT ; ITE SELECTION ; WELL DRILLING: ENERGY POLICY;GOVERNMENT POLICIES

193 GEOTHERMAL ENERGY: THE CHALLENGES THAT LIE AHEAD (PART 2 OF A TWO-PART ARTICLE). Fuchs, R.L. (Geosystems Corp., New York City): Huttrer, G.H. (Thermex Co., Denver). Eng. Min. J.: 176: No. 2, 78-82(Feb 1975). GEOTHERMAL ENERGY;EXPLOITATION;ECONOMICS; LEGAL ASPECTS; LAND LEASING; GEOTHERMAL EXPLORAT ION; BROADLANDS GEDTHERMAL FIELD; WELL DRILLING; GEOPHYS ICAL SURVEYS ; GEOTHERMAL POUER PLANTS ; LARDERELLO GEOTHERKAL FIELD ; GEYSERS GEOTHERMAL FIELD;MATSUKAWA GEOTHERMAL FIELD; POWER GENERATION;ENERGY SOURCE DEVELOPMENT

194 (NP--20667) Uncl ENERGY: 1975. THE FIRST ANNUAL REPORT OF THE IOWA ENERGY POLICY COUNCIL. (Iowa Energy Pollcy Councll, Des Molnes (USA)). 15 Jan 1975. 59p. TIC. Iowans need to make decisions to select and develop a primary source of energy for electricity generation. Iowa's energy sources, with the exception of $2 x$ from state coal and hydroelectric resources, are all imported. Future needs wili require a mix of continued large inports, development of the 7.2 billion tons of coal reserves, and/or development of renewable energy resources. The political, environmental, economic, and social

implicat lons of four options (hlgh consumptionlow production, low consumption-low production, high consumption-high production, and low consumption-high production) are analyzed, and the following recommendations made: (1) all reasonable conservation efforts should be made; (2) Individuals and corporations should seek out the opportunities that conservation offers; (3) conservation should include efforts to achleve energy efflelency, full cost pricing, and economic incentives; (4) end use control of netural gas should linit it to high priority uses: (5) oll import should be limited and balanced inventories maintained; ( 6 ) construction of new electricity generation plants should be approached conservatively: (7) Iowa should increase its research and analysis of the nuclear power potential: (8) public funds should be provided for energy $R$ and $D$; (9) energy policies should maintain high envi ronmental standards; and (10) mandatory measures should be 1 imited and energy policies should respect individual and corporate freedoms. (DCK)

195 (PB--238791) UnC1 REVIEW OF THE PROJECT INDEPENDENCE REPORT SUBMITTED TO OFFICE OF ENERGY RESEARCH AND DEVELOPMENT, NATIONAL SCIENCE FOUNDATION, JANUARY 10, 1975. Gl obe, S.: Cralg, R.A. (Battelle Columbus Labs., Ohio (USA)). 10 Jan 1975. Contract NSF-C914. 183p. NTIS $\$ 7.00$.

PROJECT I NDEPENDENCE; US FEA;REVIEUS ; ENERGY POLICY;GDVERNMENT POLICIES : NATURAL GAS ; CDAL NUCLEAR ENERGY;SOLAR ENERGY; INDUSTRY;ENERGY CONSERVATION; GEOTHERMAL ENERGY

196 RECENT DEVELOPMENTS IN THE TAXATION OF GEOTHERMAL EXPLORATION. Ei senstat, S.M. Geotherm. Energy Mag.; 3: No. 1, 17(Jan 1975). TAXES ; GEOTHERMAL EXPLORAT ION ; LEGISLATION ; USA ; FINANCING

197 TOWARDS A RESPONSIBLE ENERGY POLICY. Krutllla, J.V.; Page, R.T. (Resources for the Future Inc., Washington, DC). Pollcy Analysis; 1: No. 1, 77-100(Hin 1975).

Integration of economic and ethical factors. ENERGY POLICY; NUCLEAR ENERGY;FOSSIL FUELS; SDLAR ENERGY; GEOTHERMAL ENERGY;ENERGY CONSERVATION : COST ; ENERGY SOURCES ; ENERGY SUPPLIES; SOCIOECONOMIC FACTORS

198 (COM--75-10500) UnCl REVIEW OF PROJECT INDEPENDENCE BLUEPRINT PANEL SUBCOMMITTEE REPORTS ON FEA-INTERAGENCY TASK FORCES. REPORT ON CTAB RECOMHENDATIONS FOR A NATIONAL ENERGY PROGRAM. SUBCOMMITTEE WORKING DOCUMENTS. (Commerce Technical Advisory Board, Washington, D.C.). 1975. 308p. NTIS $\$ 9.25$.

ENERGY SOURCES;RECOMMENDATIONS; PROJECT INDEPENDENCE; FORECAST ING;US FEA; COAL LIQUEFACTION ; DATA COMPILATION; COAL GASIFICATION; ENERGY CONSERVATION : COAL PREPARATION; PETROLEUH: NATURAL GAS; NUCLEAR ENERGY; SOLAR ENERGY; GEOTHERMAL ENERGY; FLUE GAS; DESULFURIZATION; OCEAN THERMAL POWER PLANTS;WIND POWER; OIL SHALES : ENVIRONMENTAL IMPACTS GOVERNMENT POLICIES;ECONOMICS;REVIEWS

199 (CONF-750612--, pP 327-330) ROLE OF PUBLIC LANDS IN GEOTHERMAL ENERGY. Armstrong, B. (General Land Offlce, Austin, TX). 1975. From 1. geopressured geothermal energy conference; Austin, Texas, USA ( 2 Jun 1975).

First geopressured geothermal energy conference.

A brief discussion is given on legal espects of leasing of public lands for the development of geothernal resources within the state of Texas. The land commissioner of the state of Texas is charged with the management of some 22 million acres of state land. The legal aspects of 8 million acres of relinquishment act lands, of whlch the surface owner is the agent for the state in terms of leasing, are considered. (LS)

200 GEOTHERMAL ENERGY: ECONOMIC POTENTIAL OF THREE SITES IN ALASKA. Rosenbruch, J.C.; Bottge, R.G. (Bureau of Mines, Washington, D.C. (USA)). 1975. vp. Bureau of Mines. Washington, DC.

The Bureau of Mines evaluated the prospects for using geotheral energy to generate 
electricity for mines in remote areas. Given the development of a geothermal resource for this purpose, the subsidiary uses of space heating and agrlculture were then examined to see if other industries might be viable given a cheap source of heat energy. Sites investigated were located in three areas of Alaska: Kobuk in the northwest, Unalaska in the southwest, and. Stikine River in the southeast. Each site was relatively close to mineral deposits whose prospects for development would be enhanced Ith cheap power. 30 refs.

201 THE ENERGY CRISIS AND PROPOSED SOLUTIONS. PANEL DISCUSSIONS BEFORE THE COMMITTEE ON WAYS AND MEANS, HOUSE OF REPRESENTATIVES, NINETYFOURTH CONGRESS, FIRST SESSI DN ON THE ENERGY CRISIS AND PROPOSED SOLUTIONS, PART 3 OF 4. Washington, DC: Commlttee on Hays and Means (1975). 478p.

NATURAL GAS:PETROLEUM:ENERGY SUPPIIES AUTOMOBI LES; EFF I CIENCY ; ENERGY CONSERVATION; GOVERNMENT POLICIES;ENERGY POLICY;SOLAR ENERGY: GEOTHERMAL ENERGY; CDAL;URANIUM;ENERGY SHORTAGES; ECONOMICS

202 MONTANA ENERGY POLICY STUDY. Martin, D.H.: Frizzell, T.H.: Bourke, R.L. Helena, MT: Montana Environantal Quality Councll (1975). 298p. Environmental Quality Council, Montana State Leglslature, State Capitol, Helena, MT. MONTANA;ENERGY DEMAND:ENERGY SOURCES: FORECASTING; WIND POWER;COAL GASIFICATION;COAL LI QUEFACTION ; PET ROLEUM : NATURAL GAS ;ENERGY CONSERVATION : ELECTRI CI TY; COAL; URANIUM ; ECONOMICS : SOLAR ENERGY;PHOTOSYNTHESIS; GEOTHERMAL ENERGY; ENERGY POLICY

203 ERDA AUTHORIZATIDN. PART II. 1976 AND TRANSITION PERIOD: GEOTHERMAL. HEARINGS BEFORE THE SUBCOMMITTEE ON ENERGY RESEARCH, DEVELOPMENT, AND DEMONSTRATION OF THE COMMITTEE ON SCIENCE AND TECHNOLOGY, U.S. HOUSE OF REPRESENTATIVES, NINETY-FOURTH CONGRESS, FIRST SESSION. Washington, DC; Comittee on Sclence and Technology $(1975)$. 319p.

BUDGETS ; GEOTHERMAL ENERGY;HEARINGS; US ERDA RESEARCH PROGRAMS

204 NONNUCLEAR ENERGY RESEARCH AND DEVELOPMENT: FISCAL YEAR 1976 AUTHORIZATION. HEARINGS BEFORE THE SUBCOMMITTEE ON ENERGY RESEARCH AND WATER RESOURCES OF THE COMMITTEE ON INTERIOR AND INSULAR AFFAIRS, UNITED STATES SENATE, NINETY-FOURTH CONGRESS, FIRST SESSION DN S. 598. WashIngton, DC; Commlttee on Interlor and Insular Affalrs (1975). $778 \mathrm{p}$. US ERDA ; HEARINGS;BUDGETS; ENERGY SOURCES: ENVIRONMENTAL EFFECTS ENERGY CONSERVATION; SAFETY;RESEARCH PRDGRAMS ; COAL; PETROLEUM;OIL SHALES;SOLAR ENERGY;GEOTHERMAL ENERGY;ENERGY POLICY

205 ANALYSIS DF THE ERDA PLAN AND PROGRAM. Washington, DC; Oeflce of Technology Aasessment (1975). 318p. GPO $\$ 3.85$.

An anelys ls is presented of the program plan submitted by the Energy Research and Development Administration (ERDA) to Congress on June 30 , 1975, ent1tied A National Plan for Energy Research, Development, and Demonstration: Creating Energy Cholces for the Future. Included in this analysis are background date and discussions of the major is sues and questions, to enable Congress to review ERDA's energy $R$ and $D$ prograns. It is atated that the ERDA Plan (Volume I of ERDA's report) is a isignificant allestone in the evolution of a long-term national energy pollcy," but that ithe ERDA Program (Volune II), to Implement this plan, does not appear adequate to achicve the stated goals." Two najor deficiencles in the program are pointed out: (1) ERDA's emphasis on technological research with little consideration for the research needed to overcome non-technical constraints to using new technologies; and (2) insurficlent emphasis on energy conservation. (BYB)

206 AUTHORIZING APPROPRIATIONS FOR THE ENERGY RESEARCH AND DEVELOPMENT ADMINISTRATION. CONFERENCE REPORT TO ACCOMPANY H,R. 3474. Hashington, DC; Congressional Committee of Conference (1975). 83p.

Compromise by the House and Senate Conference Conmittee (chal red by Sen. Henry Jackson) was needed to bring the ERDA budget in line uth information and program developments subsequent to original requests. Decisions to accelerate non-nuclear programs led to the following changes: authorlzation for increases in solar, rossil, and geothermal prograns, and conservation $R$ and $D$; authorization for increments only for physical research, environment and safety, and program support; and no changes in advanced energy systems supporting activities, scientific and technical education, or programs conducted by the council on Environmental Quality, Water Resources Council, or National Bureau of Standards. Major additions are in Section 102 , to establish an oll shale demonstration program and in Section 103, to provide up to $\$ 6$ billion in loan guarantees for construction of comercial demonstration facilities. Increases In nuclear prograns are: (1) $\$ 99.5$ allilon for increased electrical costs at gaseous diffusion plants: (2) $\$ 1.9$ aililon for safeguards; and (3) $\$ 91.9$ million for expanded research, particularly nuclear fuel cycle and light water reactor technology. (DCK)

207 GEOTHERMAL ENERGY RESEARCH, DEVELOPMENT, AND DEMONSTRATION ACT OF 1974. OVERSIGHT HEARINGS: LOAN GUARANTIES. HEARINGS BEFORE THE SUBCOMMITTEE ON ENERGY RESEARCH, DEVELOPHENT, AND DEMONSTRATION OF THE COMMITTEE ON SCIENCE AND TECHNOLOGY, U.S. HOUSE OF REPRESENTATIVES, NINETY-FOURTH CONGRESS, FIRST SESSION. Hashington, DC; Committee on Science and Technology (1975). 692p.

The Geotheraul Loan Gueranty Progrea wea enacted in 1974 to encourage commerclal development of this new energy technology through federally guaranteed loans. Two days of hearings, chalred by Rep. Mike McCormack, were held to (1) review proposed regulations for Implementing the program and identify needed changes and (2) examine the overlap of P.L. 93-410 (the Geothermal Energy Research, Development, and Demonstration Aet of 1974) and the ERDA Authorization Blli, which 111 provide a \$6 blllion loan guarantee program. This review 111 serve s a model for the total loan program. There were elght uitnesses, representIng ERDA, Congress, and prlvate Industry, and 22 prepared atatements from both the pubilc and private sector. areas of concern Included: (1) lag tine in funding: (2) requirements for environmental etatements: (3) the extent of atate and local particlpation; (4) patent implications: and (5) a possible sianting toward big business: (DCK)

208 STUDIES IN ENERGY TAX POLICY. Brannon, G.M. (ed.). Cambridge, MA; Balilinger Publishing Co. (1975). 1p. \$15.00. Book. TAXES;ENERGY POLICY;ECONOMICS: PETROLEUY INDUSTRY; INDUSTRY ; ENERGY SOURCES: 
ENUIRONMENTAL EFFECTS; ENERGY CONSUMPTION; FINANCING; IN COME ; EXPLORA TION; GOVERNMENT POLICIES

209 AN ANALYSIS IDENTIFYING ISSUES IN THE FISCAL YEAR 1976 ERDA BUDGET - REPORT PREPARED FOR THE COMMITTEE ON SCIENCE AND TECHNOLOGY, U.S. HOUSE DF REPRESENTATIVES, COMMI TTEE ON INTERIOR AND INSULAR AFFAIRS, U.S. SENATE AND THE JOINT COMMITTEE ON ATOMIC ENERGY, NINETYFOURTH CONGRESS, FIRST SESSION. Hashington, DC; Comittee on Sclence and Technology (1975). 84p. GPO \$1.25.

BUDGETS;RESEARCH PROGRAMS;ENERGY POLICY; GOVERNMENT POLICIES; FOSSIL FUELS;COAL;NUCLEAR ENERGY ; ENERGY CONSERVATION; SOLAR ENERGY; GEOTHERMAL ENERGY;EFFICIENCY;ENERGY STORAGE: AUTOMOBILES;ENVIRONMENTAL EFFECTS; HEALTH HAZARDS; ENERGY; US ERDA

210 CONTINUING ENERGY CRISIS IN AMERICA. Washingt on, DC; Congressional Quarterly Inc. (1975). 126p. Congresslonal Quarterly Inc., 1414 22nd St., NH, Washington, DC 20037.

US ERDA; LEGAL A SPECTS; USA; PETROLEUM ;ENERGY SOURCES; ENERGY CONSERVATION; ENERGY SHORTAGES; PROJECT INDE PENDENCE; ECONDMI CS ; MARKET ; ENERGY POLICY;ECONOMIC POLICY;OFFSHORE DRILLING;CANADA; OIL SHALES;NUCLEAR FUELS; SAFETY; NATURAL GAS; COAL; TAXES ; SOLAR ENERGY; GEOTHERMAL ENERGY

211 ENERGY DEVELOPMENT AND LAND USE IN TEXAS. FINAL REPORT ON PROJECT E/S-1: IMPACT ON LAND USE AND VALUE OF ALTERNATIVE STRATEGIES FOR PRODUCTION, DISTRIBUTION, AND UTILIZATION OF ENERGY IN TEXAS IN THE PERIOD 1974--2000. McFarland, H.F. Austin, TX; State of Texas Governor's Energy Advi sory Council (1975). 127p. Texas Transportation Inst., Texas $A$ and M Univ., College Station, TX.

LEGISLATION; ENERGY; ENERGY SOURCES ; LAND USE; NATURAL GAS ; PETRDLEUH; PRODUCTION ; DISTRIBUTION; URANIUM; ELECTRIC POWER; POWER GENERATION;COAL; LI GNITE; UASTE DI SPOSAL; TEXAS ; LEGAL ASPECTS; WIND POWER; SOLAR ENERGY;GEOTHERMAL ENERGY ; NUCLEAR POWER; SOLID WASTES;ENERGY POLICY;ENUIRONMENTAL IMPACTS; ENERGY SOURCE DEVELOPMENT

212 FEDERAL ENERGY/ENUIRONMENTAL RESEARCH AND DEVELOPMENT PROGRAM. Gage, S.J.

(Environmental Protection Agency, Uashington, DC). PP 242-270 of Energy technology II. Sullivan, T.F.P. (ed.). Washington, DC; Government Institutes, Inc. (1975).

From 2. Energy Technology Conference; Washington, DC ( 12 May 1975).

ENERGY SOURCES;ENVIRONMENT; SOLAR ENERGY GOVERNMENT POLICIES; GEOTHERMAL ENERGY;FUELS; PLANNING ; RESEARCH PRDGRAMS ; LEGISLATION ; ENVIRONMENTAL EFFECTS ; ENERGY CONSERVATION ; SOLID WASTES;ECOLOGY;ECONOMICS;HEALTH HAZARDS;FUEL CELLS; PETROLEUM; NATURAL GAS; COAL; NUCLEAR ENERGY; SYNTHETIC FUELS; COAL GASIFICATION; COAL LIQUEFACTION

213 ALTERNATIVE SOURCES OF ENERGY: PRACTICAL TECHNOLOGY AND PHILOSOPHY FOR A DECENTRALIZED SOCIETY. Eccli, S. (ed.). New York; Seabury Press (1975). 279p. Seabury Press, 815 Second Ave., New York, NY $10017 \$ 6.95$. IECOLOGY;COMBINED CYCLES; SOLAR ENERGY; WIND POWER; HYDROELECTRIC POWER; ME THANE; HOOD; TRANSPORTATION SYSTEMS ; GEOTHERMAL ENERGY ; WASTE HEAT; RECOVERY; COMPRESSED AIR ;ENERGY POLICY; REGULATIONS; ENERGY CONSERVATION;ALCOHOLS : AGRICULTURE; DESIGN ;ENGINEERING ; SOLID WASTES; MAGNETOHYDRODYNAMICS;FUEL CELLS; SYNTHETIC FUELS

\section{ENERGY ALTERNATIVES: A COMPARAT IVE}

ANALYSIS. Washingt on, DC; Council on Environmental Quality (1975). 671p. GPO $\$ 7.45$, Stock No. 041-011-00025-4. SYSTEMS ANALYSIS; ENERGY. SOURCES

ENUIRONHENTAL EFFECTS;EFFICIENCY;COST; COAL;OIL SHALES; PETROLEUM; NATURAL GAS ; OIL SANDS; HYDROELECTRIC POWER; NUCLEAR ENERGY; ENERGY; GEOTHERMAL ENERGY;SOLAR ENERGY ; ENERGY CONSERVATION; COAL GASIFICATION;ELECTRIC POWER; POWER GENERATION; TRANSPORT ; ENERGY CONSUMPTION; ECONOMICS; INDUSTRY;HTGR TYPE REACTORS; LMFBR TYPE REACTORS; PROCESSING ; COMPARATIVE EVALUATIONS

215 HIGHLIGHTS OF ENERGY RELATED LEGISLATIDN IN THE 93RD CONGRESS. PREPARED AT THE REQUEST OF HENRY M. JACKSON, CHAIRMAN, COMMITTEE ON INTERIOR AND INSULAR AFFAIRS, UNITED STATES SENATE PURSUANT TO S.RES. 45. Gullck, F.A.: Hartzog, N. Washington, DC; Committee on Interior and Insular Affairs (1975). $147 \mathrm{p}$ LEGISLATION; RESEARCH PROGRAMS;ALASKA OIL PIPELINE; RESERVES ; PETROLEUM; ALLOCATIONS; ENERGY CONSERVATION; ENERGY SUPPLIES ; GOVERNMENT POLICIES; REGULAT IONS ; NATURAL GAS; SOLAR ENERGY; GEOTHERMAL ENERGY;ENERGY POLICY;ENERGY

216 ENERGY SELF-SUFFICIENCY: HOW MUCH; HOW SOON. Zraket, C.A. (Mitre Corp., McLean, VA). PP 35-44 of Mining year book, 1975 . Denver; Colorado MIning Association (1975). From National Western Mining Conference and Exhibition: Denver, Co ( 7 Feb 1975).

GEOTHERMAL ENERGY; MARKET; ENERGY POLICY;USA; SOLAR ENERGY;ENERGY CONSERVATION ; PROJECT INDEPENDENCE ; ENERGY SUPPLIES : SECURITY PETROLEUM; COAL; NUCLEAR ENERGY; NATURAL GAS;ENVIRONMENTAL EFFECTS;DEMAND FACTORS;ECONOMICS;REGULATIONS; LEASES;RESEARCH PROGRAMS;OIL SHALES; SYNTHETIC FUELS; BREEDER REACTORS; FUSION REACTIONS

217 GEOTHERMAL ENERGY DEVELOPMENT. HEARING BEFORE THE SUBCOMMITTEE ON ENERGY RESEARCH AND WATER RESOURCES OF THE COMMITTEE ON INTERIOR AND INSULAR AFFAIRS, UNITED STATES SENATE, NINETY-FOURTH CONGRESS, FIRST SESSION. Washington, $D C$; Commit tee on Interior and Insular Affairs (1975). 518p.

Delays in leasing and loan guarantee programs for geothermal research and development were the subject of committee hearings chaired by Senator Frank Church. Fourteen persons representing the Idaho Raft River Cooperative and the Bureau of Land Management made statements offering reasons for the delays, including: (1) ERDA has been indecisive and reluctant to proceed: (2) the Raft River project has a complex land pattern and private ownership: (3) Rapt River has leases to be renewed and no bases for negotiation until ERDA underwrites some of the research risks; (4) ERDA encouraged Idaho to proceed with two years of successful

exploratory drilling and has since delayed funds for further work; and (5) Pacific Northwest geothermal projects have been delayed by environmental and legal constraints, and linancing and technical problems. ERDA representatives responded that more inforation and orderly planning are needed before continuing. New technology must be developed, and ERDA prefers deliberate approach. (DCK)

218 FINANCING INFRASTRUCTURE IN ENERGY DEVELOPMENT AREAS IN THE HEST. PROCEEDINGS DF A CONFERENCE HELD AUGUST 21 AND 22, 1975, IN SNOWBIRD, UTAH. Logan, UT; Rocky Mountain Institute for Policy Research (1975). 32 . The problem of financing the intrastructure 
in energy development areas was explored in a seminar sponsored by the Rocky Mountain Instltute for Polley Research at Snowbird, Utah on August 21 and 22, 1975. Experts from industry, unlversities, and Federal, state, and Indian governments accepted the challenge of defining the parameters of this complex problem and exploring alternative solutions. Even assuming that requisite attention is given to preserving the social and natural environment, development of the energy resources located In remote areas of the Western Interior (including portions of Arizona, Colorado, Idaho, Montana, Nevada, New Mexico, the Dakotas, Utah and Wyoming) is not feasible without the emplacement of new support sectors in those areas. Urgently needed are mine-mouth industrial and residential sectors, additlonal transportation, and public facilities. The design and construction of these support systems will require large capital expenditures over and above the expenditures of private energy development corporations for mineral rights, processing plants, and transportation and transmission. Current estimates (Section III) are that more then $\$ 16$ billion will be invested during the coming decade by energy developers in the western interior. The majority of these projects will focus on coal and coal-fired electrical plants and transportation/transmission facilitles.However, sizeable sums will be dedicated to other projects, including aspects of the nuclear fuel cycle, petroleum and natural gas development, coal gasification, and ofl shale and tar sands plants, as well as some solar and geothermal prototypes. (MCW)

219 ALTERNATE ENERGY SOURCES FOR HAWAII. PROCEEDINGS OF THE WORKSHOP HELD WAY 8--9, 1975, IN HONOLULU, HAHAII. Honol ul u; Hawall Natural Energy Institute (1975). 48p. Hawali Natural Energy Inst., c/o Coll. of Engineering, Holmes Hall, University of Hawall, Honolulu, HI 96804.

In May 1974, Governor Ariyoshl appointed a Committee on Alternate Energy Resources to study the potentlal of energy resources as possible substitutes for seaborne petroleum, which Hawail depends on entirely. The Committee establ Ished task forces to evaluate ten alternate energy sources and to look into the economic, environmental, storage, and transport aspects of these energy alternatives in their report of March 1975 , it was recommended that a Workshop on Alternative Energy Sources be held. The purpose of the workshop was to incorporate the best current thinking of some of the top sclentists, engl neers, and planners in developing the optimum plan for Hawali's energy future and to provide some national visibllity to the varlety and abundance of natural energy resources in the State. U.S. FEA Regional Administrator Arntz remarked in an initial opening speech that Hawali iwas ahead of sister states in confronting its energy crisis. In the keynote speech that followed, Edward Teller, stated that alternative energy sources need to be developed that can yleld results by 1985. A summary of the ERDA energy research was presented by Louis B. Werner. Separate workshop sessions were conducted on solld waste and bioconversion, wind, solar, and geothermal energy: and, in a General Workshop sesston, the broader aspects of the Alternate Energy report were discussed and recommendations made. The program, participants, and a summary of the Committee Report are included in three appendices. (MCW)

220 ENERGY TECHNOLOGY UPDATE FOR COLORADO DECISION MAKERS. PROCEEDINGS OF A CONFERENCE
HELD MARCH 5, 1975, IN GOLDEN, COLORADO.

Golden, CO; Colorado Energy Research Institute (1975). 160p. \$5.00.

The Colorado Energy Research Inst Itute (CERI) was created to coordinate research and development in Colorado in energy-related flelds. The objective of the meeting, sponsored by CERI and Region VIII of the Federal Energy Administration, was to communicate research and development information on technological, as well as social, economic, and environmental matters to the leaders in government and Industry to provide the basis for energy decisions. Ten papers were presented following opening remarks by $T$. J. Vogenthaler, Director of CERI, and by Gordon Altot, Jr. Irom FEA. The papers are entitled: Environmental Impact of Technologlcal Development; Advanced Systems-Hind, Hydrogen, and MHD; Nuclear Power-Present Reactor Technology: Coal Gasification and Liquefaction; Geothermal Energy; Solar Heating and Cooling: 0il Shale; Solar Thermal Power; Coal Recovery and Mining; and Energy Conservation. (MCW)

221 ENERGY POLICIES OF THE HORLD: VENEZUELA. Martinez, A.R. Newark, DE; University of Delaware (1975). 100p. \$3.50.

Venezuela ranks fifth in the world in total oll output and 92 percent of its production in 1974 was exported, making it the third largest exporter after Saudi Arabla and Iran. No comprehensive energy policy has been reached yet, but important separate decisions by the government indicate pollcy directions. The use of energy in Venezuela has been conditloned by the characteristlcs of the existing resources and by the political-economic plans that evolve from private cholces and government regulation. The success of the pollcy will depend upon the effectiveness, efficlency, and authority of the government and its several agencles: $A$ bill ordering the natlonalization of the petroleum industry in venezuela was signed into law by the President on August 29, 1975. In this work, the author has also analyzed the production and reserve data for natural gas, ofl shales, hydraulle power, coal, nuclear flssion resources, and solar, wind, tldal, and geothermal energy for Venezuela. Following the chapter on issues, the chapters are entitled: HIstorical Development of Energy Uses; The Energy Resources of Venezuela: The Production and Consumption of Energy in Venezuela: Means and Ends in Formulating Policy; and

Recommendations for a Venezuel an Energy Policy. The linal chapter on observations and canclusions is followed by 1 isting of 17 selected references. (MCW)

222 REICH CASE: ECONOMIC IMPLICATIONS OF DEPLETION ALLOWANCES. Peterson, R.E.: SeO, K.K. (Univ. of Hawail, Honol ulu). Geothermics; 4: No. 1-4, 66-75(1975).

The Relch case was tried in the 1969 rax Court of the United States and the Court held that geothermal stean is a gas and is an exhaustible resource at The Geysers field. Accordingly, all geothermal stean producers are now entitied to deduct as current expense the intanglble costs of developing and drilling geothermal steam wells and all producers who can demonstrate that their geothermal steam resource is depletable are entitled to what is now a 22 percent depletion allowance. The key expert witness in the case was Dr. Henry $J$. Ramey, Jr. and a summary is presented of his monograph which was submitted as evidence. His conclusion, based on a reservolr engineering analysis, was that the geothermal resource at the Big Geysers area had, as of 1968, 20 to 46 years of productive life remaining. In the 
economics discussion, it is demonstrated that the corporate Incone tax discriminates agalnst risky and capital-intensive industries such as ol $l$ and gas and geothermal. The central economic argument in favor of percentage depletion allowances and expensing privileges is that these provisions remove the discriminatory bias of corporate income taxes. The economic consequences of depletion allowances are: a short- and long-run increase in production; short- and long-run increase in investment in renewal--exploration, discovery, and development; lower prices; a ratio of reserves to output--the life Index-whlch tends to be constant; and a short-run increase in profits which encourages the entry of new firms and long-run situation in which average rates of return are again equalized across industries.

223 PROCEEDINGS OF CITIZENS FORUM ON POTENTIAL FUTURE ENERGY SOURCES HELD AT PORTLAND, OREGON, JANUARY 17, 1974. Portland, OR; Oregon Department of Geology and Mineralogy Industry (1975). $62 p$.

Six papers presented at this forua deal with various aspects and the future potential of wind power, solar power, geothermal power, conversion of oll shale, and coal gasification and liquefaction. The data and its interpretation hould provide some of the inforation necessary to understand the advantages and $11 \mathrm{mitat}$ lons of some of the alternate sources of energy.

224 GEOTHERMAL ENERGY AND THE LAW. I. THE FEDERAL LANDS MANAGEMENT PROGRAM. Stone, C.D. Los Angeles; Univ. of Southern Callfornia Law Center (1975). $287 \mathrm{p}$.

$A$ broad range of problems in the legal and Institutional environment which hampers the development of the geothermal industry is discussed. The toples include: the development of geothermal energy; pre-leasing procedures, public va private assessment, exploratory permits, and related strategies; the rate of geothermal leasing, past and future; compensation strategies; lessee qualifications: lands available for leasing, noncompensatory lease terns; ongolng leasehold and production requirements; problems of 'secondary'"

geotheral uses: and water law conflicts. (LBS)

225 GEOTHERMAL ENUIRONMENTAL ADVISORY PANEL. FIRST ANNUAL REPORT, JUNE 1, 1974--JUNE 30, 1975. Menlo Park, CA; Geologlcal survey (1975). 8p.

Progress is reported in studying the basel Ine ecology for potential geothermal development in order to present guidellnes for environaental stendards, required for inplementing the monitoring requirements of 30 CFR 270.34(k). Program goals are consistent with the Department of the Interior's overall wineral management polfcy, which seeks to assure orderly and timely resource development, protection of the environment, and recelpt of falr market value for disposition of mineral resources. (PCS)

226 FINANCIAL ASPECTS OF GEOTHERMAL RESOURCES DEVELOPHENT, SAN FRANCISCD, CALIFORNIA, OCTOBER 23--24, 1975. Dav1s, CA: Geothermal Resources Councli (1975). 172p.

Sixteen papers were included. Separate abstracts were prepared for six. (MHR)
B. (Chevron 011 Co., San Francisco). Pp 1336 of Financial aspects of geothermal resources development, San Francisco, California, October 23--24, 1975. Dav1s, CA; Geothermal Resources Counc1 i (1975).

The following toplcs are discussed: electricity market, fuels, nuclear competition, U.S. Industry, profitability, exploration costs, IInancing project in the U.S.A. and elsewhere, steam and hot water systems, comparison of generating systems, and geopressured systems. Key Issues to be resolved for economic and beneficial use or geothermal energy are listed. (MHR)

228 U.S. ENERGY RESOURCES DEVELOPMENT ADMINISTRATION: GEOTHERMAL LOAN GUARANTY PROGRAM. pp 37-40 of Financlal aspects of geothermal resources development, San Francisco, Callfornia, October 23--24, 1975. Davis, CA; Geothermal Resources Councli (1975). The program is outlined briefly under the following headings: legislative authority, program obectives, principles gulding progran implementation, formulation of regulations, eligible purposes/priorities for guaranties, program feetures, and loan processing flow chart. (MHR)

229 GEOTHERMAL TAX CONSIDERATIONS AND SHELTERS. El senstat, S.M. (EI senstat and Gottesman, New York). PP 49-52 of Financlal aspects of geothermal resources development, San Francisco, California, October 23--24, 1975. Davis, CA; Geothermal Resources Councll (1975).

Legal decislons resulting from

Implementation of Treasury regulations ( 26 CFR 612: 613; 704; 752; 741; 731) are revlewed for the effect they have on geothermal exploration linancing. Tax laws and tax shelters for oil, gas, and geothermal are currently belng revised in Congress. Tangible and intanglble drilling costs; partnership interests sale, nonrecourse loans, personal income, and percentage depletion allowance are some of the topics di scussed. (PCS)

230 GEOTHERMAL EXPLORATION AND DEVELOPMENT IN THE UNITED STATES: A TAX ANALYSIS UNDER THE INTERNAL REVENUE CODE. Elsenstat, S.M. (Elsenstat and Gottesman, New York). pp 59-65 of Financial aspects of geothermal development, San Francisco, Callfornia, Detober 23--24, 1975. Davis, CA; Geothermal Resources Council (1975).

The tax incentlues are examined as they apply to geothermal activities under the following headings: Intanglble drilling deduction and percentage depletion, tax consequences in exploring and developing geothermal resources, and tax planning. feu cases providing legal precedents are mentioned and varlous regulations are indicated in footnotes. (MHR)

231 FORMATION, FUNDING, AND DEVELOPMENT OF A SMALL EXPLORATION COMPANY. Castellanos, H.P. Jr. (Diablo Exploration, Inc., Oakland, CA). pp 67-70 of financlal aspects of geothermal resources development, San Francisco. Callfornia, October 23--24, 1975. Dav1s, CA; Geothermal Resources Council (1975).

Procedures, problems, and speclal considerations for the development of the geothermal industry are outlined. (MHR)
227 STATUS OF ECONOMICS AND FINANCING GEOTHERMAL ENERGY POWER PRODUCTION. Grelder, 
Exploration, Inc., Denver). pp 131-138b of Financial aspects of geothermal resources development, San Francisco, Callfornia, Detober 23--24, 1975. Davis, CA: Geothernal Resources Counc 11 (1975).

The following topics are examined briefly: the nature of the geothernal resource: prospecting concerns; production practice; market ing aspects: environmental concerns; geothermal's probable abundance; appllcable land: legal and Institutional considerations: and investment and revenue timing compared to mining. A case is made for reallstic legislative treatment of geothermal resources in line with other sub-surface resources. (MHR)

233 LEGAL AND INSTITUTIONAL FACTORS. GEOTHERMAL RESEARCH STUDY IN THE SALTON SEA REGION OF CALIFORNIA. Bates, M.R.; Krier, J.E.: Montgomery, H.D. Pasadena, CA; Callfornia Inst. of Tech. (1975). 18p.

Recomendations are discussed for the conduct of research and demonstration program directed to commercial exploitation of the geothermal resources of the Salton Sea region of California. The legal ond institutional aspects of geothermal energy exploftation which need study are described. (MHR)

234 GEOTHERMAL RESOURCES OPERATIONAL ORDER NO. 1: EXPLORATORY OPERATIONS. Washington, DC; Geological Survey (1975). 7p.

This Order (effectlve February 1, 1975) is established pursuant to the cuthority prescrlbed in 30CFR270.11 and in accordance wth 3OCFR270.78. All exploratory operations other than drilling of exploratory and development wells will be conducted in accordance with the provisions of this Order. All plans for exploratory operat lons to be conducted shall Include provisions for appropriate environmental protection and reclamation of disturbed lands. A cultural resources Investigation approved by the Area Geothermal Supervisor shall be performed prior to any surface disturbance other than casual use. All varlances from the requirements specifled In this Order shall be subject to approval pursuant to 30 CFR270.48. The following exploratory operatlons are delineated: casual use, geophysical exploration, drilling of shall ow wells, and reporting completion of exploration operations, general safety and environmental aspects, and notifleation of entry.

235 GEOTHERMAL RESOURCES OPERATIONAL ORDER NO, 2: DRILLING, COMPLETION, AND SPACING OF GEOTHERMAL WELLS. Washington, DC; Geological Survey (1975). 15p.

Thls Order (effective February 1, 1975) is established pursuant to the authority prescribed in 30 CFR270.11 and In accordance with 30CFR270.14, 270.15 , and 270.40 . All wells shall be drilled in such manner as to alnimize damage to the environment and to protect life, heal th, property, usable ground waters, and geothermal resources. After some generalized instructions are given, specific requirements for the lesser to comply with are given on: well casing; blowout prevention: equipment and procedures: drilling flulds; well logging; wellhead equipment and testing; and well spacing.

236 GEOTHERMAL RESOURCES OPERATIONAL ORDER NO. 3: PLUGGING AND ABANDONHENT OF WELLS. Washington, DC; Geological Survey (1975). 5p. This Order (effective Februery 1,1975 ) is established pursuant to the authority prescribed in 30CFR270.11 and in accordance with 30 CFR270.14 and 270.45 . The lessee shall comply with the following minimum plugging and abandonment procedures for all geothermal resources wells. Oral approvals shall be in accordance wth 30cFR270.11. All variances from the requilements speclfied in this order shall be subject to approval pursuant to 30CFR270.40. Each Sundry Notice (Form 9-331) shall Include a notation of any proposed variances from the requirements of this order. References in this Order to approvals, determinations, or requl rements are to those given or made by the Area Geotheral Supervisor or his delegated representative. Specific directions are glven for: permanent abandonment, temporary abandonment, and suspended wells.

237 GEOTHERMAL RESOURCES OPERATIONAL ORDER NO. 4: GENERAL ENVIRONMENTAL PROTECTION REQUIREMENTS. Washington, DC: Geological Survey (1975). 21p.

This Order (effective August 1,1975 ) is established pursuant to the authority prescribed in 30CFR270.11 and in accordance with 30CFR270.2, 270.34(k), 270.37, 270.41, $270.42,270.43,270.44$, and 270.76 . Lessees shall comply with the provisions of thls Drder. All varlances from the requil rements specified In this Drder shall be subject to approval pursuant to 30CFR270.48. References in this Order to approvals, determinations, or requirements are to those glven or made by the Area Geothermal Supervisor or hls delegated representative. Guldelines are speciflcally discussed for the following areas: aesthetics; land use and reclamation: public access: recreation; slope stablilty and erosion control; blota; cultural resources preservation: subsidence and selsmicity: pollution, waste disposal, and fire prevention; water quallty; and nolse abatement.

238 STRUCTURE OF THE GEOTHERMAL INDUSTRY THROUGH 1974. Montgomery, H.D. Pasadena, CA: California Institute of Technology (1975). 99p.

Four chapters are included which deal, respectively, with the technical and institutional conditions that shape geothermal development, the factors that determine the value of a geothermal lease, patterns of bldding for geothermal leases offered by the Federal government, and the emerging structure of the geothernal industry. The fInal chapter 1s summary of conclusions and recommendations for further research.

239 (NSF/RA/N-74-159, PP 111) ROLE OF THE U.S. GEOLOGICAL SURVEY IN ASSESSING THE NATION'S GEOTHERMAL ENERGY RESOURCES. Eaton, G.P. (Geologlcal Survey, Denver). 31 Dec 1974.

From Proceedings of the conference on research for the development of geothermal energy resources; Pasadena, CA ( 23 sep 1974). Proceedings of the conference on research for the development of geothermal energy resources.

US ORGANIZATIONS; USA; GEOTHERMAL RESOURCES; PUBLIC LANDS; GEOTHERMAL EXPLORATION;RESEARCH PROGRAMS; GEOLOGICAL SURUEYS; GEOPHYSICAL SURVEYS; GEOCHEMICAL SURVEYS: HYDROLOGY

240 (NSF/RA/N--74-159, pp 160-163) IMPERIAL VALLEY'S PROPOSAL TO DEVELOP A GUIDE FOR GEDTHERMAL DEVELOPMENT WITHIN ITS COUNTY. Plerson, D.E: (Imperlal County Department of Public Works, El Centro, CA). 31 Dec 1974. 
From Proceedings of the conference on research for the development of geothermal energy resources; Pasadena, CA (23 Sep 1974). Proceedings of the conference on research for the development of geothernel energy resources.

IMPERIAL VALLEY;GEOTHERMAL RESOURCES; PLANNING;SITE SELECTION;ECONOMIC DEVELOPMENT; LAND USE;ENVIRONYENTAL EFFECTS; GEOLOGY: ENGINEER ING; RESEARCH PROGRAMS; ENERGY SOURCE DEVELOPKENT

\section{1 (NSF/RA/N--74-159, Pp 331-334)}

COOPERAT IVE EFFORTS BY INDUSTRY AND GOVERNMENT TO DEVELOP GEOTHERMAL RESOURCES. Butler, D.R. (Chevron 011 Mineral s Staff, San francisco). 31 Dec 1974.

From Proceedings of the conference on research for the development of geothermal energy resources; Pasadena, CA (23 Sep 1974). Proceedings of the conference on research for the development of geothermal energy resources.

GOVERNMENT POLICIES;USA;RESEARCH PROGRAMS; INDUSTRY;US ORGANIZATIONS ; PLANNING;GEOTHERMAL ENERGY;ENERGY SOURCE DEVELOPMENT

242. (NSF/RA/N--74-159, PP 122-127) LEASING OF FEDERAL GEOTHERMAL RESOURCES. Stone, R.T. (Geological Survey, Menlo Park, CA). 31 Dec 1974.

From Proceedings of the conference on research for the development of geothermal energy resources; Pasadena, CA ( 23 Sep 1974). Proceedings of the conference on research for the development of geothermal energy resources.

GEOTHERMAL RESOURCES; LAND LEASING;PUBLIC LANDS; RE GULATIONS; US ORGANIZATIONS;USA

\section{3 (NSF/RA/N--74-159, PP 139-159)}

INSTITUT IONAL AND ENVIRONKENTAL PROBLEMS IN GEOTHERMAL RESOURCE DEVELOPMENT. Maslan, F Gordon, T.J.: Deltch, L. (Futures Group, Glastonbury, $C T)$. 31 Dec 1974 .

From Proceedings of the conference on research for the development of geothermal energy resources; Pasadena, CA ( 23 Sep 1974). Proceedings of the conference on research for the development of geothermal energy resources.

REGULATIONS;ENVIRONMENTAL IMPACTS ; GEOTHERMAL ENERGY;GEOTHERMAL RESOURCES; INDUSTRY ;ECONOMIC DEVELOPMENT: ENERGY SOURCE DEVELOPMENT

244 (CONF-741145--1) Uncl SUMMARY GUIDE TO THE INSTI TUTIONAL PROBLEMS CONFRONTING THE GEOTHERMAL ENERGY INDUSTRY. Finn, D.F.X. (Geothermal Energy Inst., San Francisco, Calif. (USA)). 10 Dec 1974. 10p. Geothermal Energy Institute, 680 Beach Street, San Franci sco, CA 94109.

Frow Annual meeting Society of Economic Geologists; Mlaml, Florida, USA (18 Nov 1974).

GEOTHERMAL RESOURCES; REGULATIONS; LEGAL AS PECTS; PLANNING; RECOMMENDAT IONS;ENVIRONMENT : INDUST RY ; LEGISLATI ON ; LEASES : TAXES ; GEOTHERMAL EXPLORAT ION; GEOTHERMAL ENERGY; GDVERNMENT POLICIES

\section{GEOTHERMAL RESOURCES RESEARCH AND} TECHNDLOGY. Kruger, P. (Adv. Geothermal Energy Res, and Tech., Natl. Sci. Found.). Aware; No. 51, 2-7(Dec 1974).

From Conference on Research for Development of Geothermal Energy Resource: Pasadena, CA (23-5 Sep 1974).

USA;GEOTHERMAL ENERGY; GEOTHERMAL RESOURCES;
POUER DEMAND;ENERGY DEMAND;RESEARCH PROGRAMS; PLANNING;EXPLOITATION; GEOTHERMAL EXPLORATION: INDUSTRY; GOVERNMENT POLICIES;FINANCING;CAPITAL; WELL DRILLING; GEOTHERMAL ENERGY CONVERSION; ENUIRONMENTAL EFFECTS;LEGAL ASPECTS; INVESTMENT : ECONOMICS

246 FEDERAL ENERGY ADMINISTRATION HEARING ON WESTERN REGIONAL RESOURCE DEVELOPMENT Aldiln, J.H. Geotherm. Energy Mag.; 2: No. 12, 24-28(Dec 1974). GEOTHERMAL RESOURCES; HEARINGS; USA; GOVERNMENT POLICIES; LEGAL ASPECTS OUS FEA;PROJECT INDEPENDENCE;ENERGY SOURCE DEVELOPHENT

247 GEOTHERMAL ENERGY: POTENTIALLY THE HEST'S MAJOR ENERGY RESOURCE. BOWER, R.G. Geotherm. Energy Mag i; 2 : No. 12, 29-30(Dec 1974).

Project Independence hearings. GEOTHERMAL ENERGY;USA;GEOTHERMAL RESOURCES; HEARINGS;POHER POTENTIAL; PROJECT INDEPENDENCE

248 SOLAR AND GEOTHERMAL ENERGY: NEW COMPETITION FOR THE ATOM. Sclence; 186: No. $4166,811-13$ (29 Nov 1974). SOLAR ENERGY;GEOTHERMAL ENERGY;REVIEWS : ECONOMICS; LEGAL ASPECTS

249 (NP--20555) UnCl WESTERN STATES HATER REQUIREMENTS FOR ENERGY DEVELOPMENT TO 1990. (Western States Water Council, Salt lake City, Utah (USA)). Nov 1974. 44p. Hestern States Water Council, Rm. 1725, Univ. Club Bldg., Salt Lake City, UT 84112 . NEW MEXICD;NEVADA; HATER RESOURCES ; OREGON; PROCESSING;UTAH;ENERGY SOURCE DEVELOPMENT; WASHINGTON;HYDROELECTRIC PONER PLANTS; URANIUM; NATURAL GAS; PETROLEUM; COAL; GEOTHERMAL ENERGY; REGULATIONS; LEASING;ENVIRONMENTAL EFFECTS: CONSUMPT ION RATES; AR IZONA ; CALI FORNIA; COLORADO; IDAHO; MONTANA; WYOMING; WATER REQUIREMENTS

\section{0 (NP--20944) UnCl PROJECT}

INDEPENDENCE. FINAL TASK FORCE REPORT: GEOTHERMAL ENERGY. (Federal Energy

Administration, Washington, D.C. (USA)). Nov

1974. 123p. GPO $\$ 2.00$.

This report contains the final technical analysis of the Project Independence

Interagency Geothermal Task Force chalred by the National Sclence Foundation. The potential of geothermal energy, resources, fuel cycles, and the status of geothermal technology are outlined. Some constraints inhlbiting rapid and widespread utilization and some Federal actions to renove utllization barriers are described. ( $\mathrm{HOW}$ )

251 GEOTHERMAL RESOURCE CHARACTERISTICS, EXPLORATION CONSIDERATIONS, AND PROPERTY ACQUISITION TECHNIQUES. Ol son, H.J.; Dolan, H.H. (Amax Exploration, Inc., Denver). Econ. Geol.; 69: No. 7, $1185($ Nov 1974). GEOTHERMAL RESOURCES; GEOTHERMAL EXPLORATION INDUSTRY; MINING; PETROLEUM; LAND USE ; COST; LEGAL ASPECTS: LAND LEASING

252 INSTITUTIONAL, BUSINESS, AND FINANCIAL ASPECTS OF THE GEOTHERMAL ENERGY INDUSTRY. Finn, D.F.X. (Geothermal Energy Inst., San Franclsco, CA). Econ. Geol.; 69: No.7, 1179 ( Nov 1974).

GEOTHERMAL ENERGY; LEGAL ASPECTS ; ECONOMICS; TAXES; GDVERNMENT POLICIES; REGULATIONS; LAND LEASING; F INANCING 
253 GEOTHERMAL: AS UE SEE IT TODAY. Otte, C. (Union OIl Co., los Angeles). PP 16-21Á of Pacific Southwest energy and minerals conference. Denver; Dept. of the Interior (Nov 1974 ).

From Paciflc Southwest energy and minerals conference: Los Angeles, CA, USA (11 Nov 1974). The normal geothermal gradient is about $1.50 \mathrm{~F}$ per 100 feet, or at a depth of $15,000 \mathrm{ft}$ the temperature equals about 2500 . This temperature is too deep to capture, but in some areas molten rock or magme formed at great depths in the crust succeeds in working itself close to the surface; this causes a sharp steepening of the geothermal gradient that may be 10 times the normal gradient. One such belt extends from the tip of South America through North Amerlca, Alaska, and around the Western Paciflc. Thls belt delineates areas of geothermal development, New Zealand, Chile, Mexico, Callfornla, Kamchatka, Japan, and the Phillppines. Other areas include I taly and Iceland. The hlstorical development of the utflization of geothermal steam in these areas is reviewed. Developments in the U.S. began in 1960 at The Geysers with $12,500-k H$ generating plant, and now installed generating capacity Is $412,000 \mathrm{kH}$, the largest in the world. U.S. geothermal developments are underway in the Jemez Mountains in New Mexico and the Imperial Valley of Callfornia. In the U.S., geothermal power is developed in increments of 50 to 100 MW, which appear to be optimum blocks of power for the number of wells required, the plpeline distance, and size and cost of the turbine. At increments of $100 \mathrm{MW}$, geothermal power is economically competitive with energy produced by fossil fuel and nuclear plants of about 1000MW size that enjoy the advantage of economy of scale. Many developing countries cannot handle such large increments as $1000 \mathrm{MH}$ to their installed capactty, and smaller blocks of cossil power are uneconomic. This makes geothermal power a very attractive form of power generation in the developing countries that have geologic potential. Four

institutional constraints to geothermal development include environmental control, leasing regulations, ounership of geothernal resources, and tax treatment. 4 ligures. (MCW)

\section{4 (NSF-RA-N--74-244) UnCl IMPACT OF} STATE AND FEDERAL LAW ON DEVELOPMENT OF GEOTHERMAL RESOURCES IN TEXAS. PROJECT L/R-9, FINAL REPORT. Edwards, T. (Texas Governor's Energy Advisory Council, Austin (USA)). 31 Det 1974. 56p. National selence Foundation, Washingt on, DC.

The significant geothermal resource in Texas conslsts of enormous reservolis of hot, geopressured water, which formed long the Gulf Coast when water-laden sediments were deposited between surrounding impermeable features, so that the water whlch would otherwise have been forced out of the sediments was unable to escape. These deposits exist under tremendous pressure created by the weight of the overburden. A geopressure source absorbs heat indirectly, because the geopressured deposits create an insulating barrier that traps and absorbs the thermal energy of the underlying magma. The water from a geopressure source will not be as hot as water from a dry stean or wet stean source, but the quantity avaliable is enormous, and the water pressure itself would be an additional energy source along with the thernal energy. The water may be fresh, or nearly so, and it will contain significant amounts of recoverable methane gas in solution. It may be possible to utilize the water pressura, thermal energy, and the methane gas to generate electricity in small power plants at the recovery site, and the water that has been passed through the turbines and heat exchangers may be a valuable by-product in Itself, depending on its quality and regional demands for agriculture and industry. One of the impediments to the development of this resource, given the very sizable commitments of capital entalled, is the uncertain legal status of geothermal resources. This report attempts to locate geothermal resources within the general $t$ ramework of Texas property law and to determine whether these resources can be developed under the law as it now exists. (MCH)

255 HAWAII GEOTHERMAL LAW. Sheets, G.M. Geotherm. Energy Mag.; 2: No. 10, 26-27(Oct 1974).

HAWAI I GEOTHERMAL RESOURCES ; LEGISLAT ION MINERALS ; ORES ; GEOLOGIC DEPOSITS ; MINING; PUBLIC LANDS

256 UNION OIL TESTIMONY: GEYSERS POWER PLANT 12 HEARING (CALIFORNIA PUBLIC UTILITIES COMMISSION). Suter, V.E. Geotherm. Energy Mag.; 2: No. 10, 20-25(Oct 1974). GEYSERS GEOTHERMAL FIELD; ENVIRONMENTAL EFFECTS;GEOTHERMAL POHER PLANTS;INDUSTRY: HEARINGS; WELL DRI LLING ; PLANNING;DRILLING FLUIDS

257 INSTITUTIONAL, BUSINESS, AND FINANCIAL ASPECTS OF THE GEOTHERMAL ENERGY INDUSTRY (ABSTRACT). Finn; D.F.X. (Geothermal Energy Inst., San francisco). Geol. Soc. An., Abstr. Programs: 6: No. 7, 735(Det 1974).

From 1974 annual meetings of the Geological Society of America; Miami Beach, FL, USA (18 Nov 1974).

GEOTHERMAL ENERGY ; LEGAL ASPECTS ; ECONOMIC DEVELOPMENT ; LEGI SLATION; REGULATIONS; TAXES; GEOTHERMAL EXPLORATION;FINANCING

258 GEOTHERMAL RESOURCES: POTENTIAL ENERGY GIANT. Verespef, M.A. Ind. Week; 182: No. 11, 48-60(9 Sep 1974).

Energy from geothermal resources could save the USA in a given year, from $5601 \times 106$ to $5.61 \times 10^{\circ}$ barrels of oll by year 2000 . Geothermal potentlal, principles and occurrence of geothermal energy, funding and agencles in the USA for promoting geothermal energy research, technology and experlence al ready avallable, and legal and environmental aspects are examined.

259 PACKWOOD GEOTHERMAL BILL (SENATE BILL S. 3392 ). Packwood, R. Geotherm. Energy Mag.; 2: No. 9, 33-37( Sep 1974). GEOTHERMAL ENERGY; LEGISLATION ;USA

260 ENERGY SYSTEMS. I. Haefele, Holf (Kernforschungszentrum Karlsruhe (F.R. Germany). Inst. (uer Angewandte Systemtechnik und Reaktorphys(k). Indian J. Power River Val. Dev.; 24: No. 9, 261-270( Sep 1974). Rapid increase in energy utilization has created the energy problem for tackling which it is necessary to adopt a systems approach. The components of any energy system are: its (i) production (11) handling and (iii) embedding into global and social complex. For proper understanding of the energy problem, three overlapping time phases are considered: (1) the short range phase 1970-1985 (2) the medl um range phase 1980-1995 and (3) the long range phase 1990-2050, each of which will be characterised by the utilization of particular sources of energy in a certain pattern which is described. The role of nuclear power in 
relation to other sources of energy is outlined. Sensing, optialzation and forecasting are the three aspects of nodeliling of energy demand and supply, which are discussed. In detall. Estinates of: (1) known and unknown reserves of fossil fuel and nuclear fuel in terms of uranium and thorium deposits and (il) II thium and deuterlum resources in view of the feasibility of fuston power are given. Besldes nuclear power either by fission or fusion, the other options for the large-scale supply of energy (1.e. a few Q/year for a thousand year or much more) are: (1) geothermal sources and (11) solar power, of which the reasibility is di scussed.

261 GEOTHERMAL ENERGY EXPLORATION, RESEARCH AND DEVELOPMENT. SENATE REPORT NO. 93-849. Washington, DC; US Senate Committee on Interior and Insular Afralrs (15 May 1974). 13p. GEOTHERMAL ENERGY; GEOTHERMAL EXPLORATION: RESEARCH PROGRAMS; HEARINGS;LEGAL ASPECTS: RECOMMENDATIONS ; USA

262 (IID--26559) UnC1 FEDERAL ENERGY REGULATION: AN ORGANIZATIDNAL STUDY. (Federal Energy Regulation Study Tean (USA)). Apr 1974. 152p. DeP. NTIS \$10.75. REGULAT IONS; USA ; ENERGY POLICY : MANAGEMENT: RECOHMENDATIONS ; ORGANIZING;ENERGY : TRANSPORT REGULATIONS; FOSSIL FUELS;ELECTRIC POUER;NUCLEAR FUELS; ENUIRONMENTAL EFFECTS; PQUER GENERATION; SAFEGUARDS ; SECUR T TY; SITE SELECTI DN;GEOTHERMAL ENERGY;RAILWAYS; GASIFICATION; POUER TRANSMISSION: HYDROELECTRIC POWER;LICENSING

263 GEOTHERMAL RESOURCES LEGAL AND TAX CONSIDERATIONS. Burton, W.A., Jr. (Chevron OIl Co., Hestern Div., Denver, CO). Geotherm. Energy Hag •: 2: No. 4, 21-4(Apr 1974). GEOTHERHAL RESOURCES :LEGAL ASPECTS;LAND LEASING; TAXES

\section{LEGISLATIVE GOALS OF ELECTRIC COMPANIES}

IN 1974. Toll, D.R. Publle UtIl. Fortn.: 93: No. $6,17-19(14$ Mar 1974). ENUIRONHENTAL PROTECTION AGENCY:LAHS:

ELECTRIC POWER: POWER PLANTS; POLLUTION; ENERGY SOURCES; MINING : COAL; NUCLEAR POWER;ENERGY POLICY; GEOTHERMAL ENERGY; SOLAR ENERGY;ENERGY SOURCES; LEGISLATION; PUBLIC UTILITIES

265 ROTORUA CITY (NEH ZEALAND) REGULATIONS ON GEOTHERMAL ENERGY. Geotheraics; 3: No. 1, 3139( $\operatorname{Mar} 1974)$.

Text of the Rotorua C1ty' Geothermal Energy By-Law 1973 is given. (PCS).

266 GEOTHERMAL POHER EXPANSION IN CALIFORNIA. Electr. Rev. (London); 194: No. 5, 138 (15 Feb 1974).

The largest geothermal installation in the world at Geysers, California now has a capacity of $396 \mathrm{MW}$. Further expansion is envisaged to a total capecity of 847 MH by 1976. A study of geotheraal resources in USA by University of Alaska estlmated that by 1985 geotheral energy could provide $10^{\circ}$ MWh and $3.1 \times 10^{\circ}$ MWh by 2000. The US Department of Interior is leasing 50,000 acres of federal land in California to private industry to develop geothermal sources, three areas contain geothermal steam and superheated water which can be used for direct generation of electricity.

267 DECISION STATEHENT OF SECRETARY OF INTERIOR ON GEOTHERMAL RESOURCES PROGRAM.
Morton, R.C.B. Geotherm. Energy Mag.: 2: No. 2, 22-24(Feb 1974).

GEOTHERMAL RESOURCES ; PRODUCTION ; USA ; RESERVES : ENERGY SOURCES ; ECONOMICS ; ENUIRONMENT :

REGULATIONS ; LAWS ; SAFEGUARDS ; INDUSTRY : STANDARDS : GEOTHERMAL EXPLORAT ION; LEGAL ASPECTS; GEOTHERMAL ENERGY;GOVERNMENT POLICIES - DECISION HAKING

268 LAW NEEDED FOR GEOTHERMAL ENERGY. Fannin, P. Public Util. Fortn.: 93: No. 3, 15-17( 31 Jan 1974).

LAWS; GEOTHERMAL ENERGY;LEGAL ASPECTS: ABUNDANCE;USA; GEOTHERHAL EXPLORATION: ENUIRONMENT; COST

269 (CONF-740209- , PP 617-632) PENULTIMATE GEOTHERMAL SYSTEM IN LEGAL PERSPECTIVE. Sheets, G.M. (UnIv. of Hawall, Honolulu). 1974.

From U.S.-Japan cooperative sclence seminar on the utillzation of volcano energy: Hilo, Hawa 11, USA ( 4 Feb 1974).

Utilization of volcano energy. Proceedings of a conference, Hilo, Hawail, February 4--B, 1974 .

GEOTHERMAL SYSTEMS : LEGAL ASPECTS; GEOTHERMAL RESOURCES ; OFFSHORE SITES ; DRILLING; GEOTHERMAL ENERGY CONVERSION

270 (CONF-741245--3) UnC1 GEOTHERMAL RESOURCE CHARACTERISTICS, EXPLORATION CONSIDERATIONS, AND PROPERTY ACQUISITION TECHNIQUES. Olson, H.J.: Dolan, H.M. (Purdue Unive, Lafayette, Ind. (USA). Automatic Control Center). 1974. 14p. Aaax Exploration, Inc., 4704 Harlan St., Denver, CO 80212.

From Annual meeting Soclety of Economic Geologists; Miaml, Florida, USA (18 Nov 1974).

GEOTHERHAL RESOURCES; REGULATIONS ; LEGAL ASPECTS; ECONOMICS ; GEOTHERMAL EXPLORATION : LAND USE: LAND LEASING; COMPARATIVE EVALUATIONS: PETROLEUH INDUSTRY; MINING; INDUSTRY

271 (LBL-3099) UnCl PROCEEDINGS OF THE GEOTHERMAL POWER DEVELOPMENT CONFERENCE, UNIUERSITY OF CALIFORNIA, BERKELEY, JUNE 18, 1974. (Californla Univ., Berkeley (USA). Lawrence Berkeley Lab.). 1974. Contract W7405-eng-48. 127p. (CONF-740654--). Dep. NTIS $\$ 5.45$.

From Geothermal power development conference: Berkeley, Californla, USA (18 Jun 1974). The proceedings of the Geothermal Power Development Conference summarize the conduct of $A E C ' s$ research and development act Ivities in geothermal energy. Six project summaries are included; a separate abstract was prepared for each. (LS)

272 RESEARCH, DEVELOPHENT, AND THE ENERGY CRISIS. HEARING BEFORE THE SUBCOMMITTEE ON ENERGY OF THE COMMITTEE ON SCIENCE AND ASTRONAUTICS, U.S. HOUSE OF REPRESENTATIVES, NINETY-THIRD CONGRESS, FIRST SESSION, NOVEMBER 20, 1973. Washington, DC: Committee on Science and Astronautics (1974). 210p. RESEARCH PROGRAMS: ENERGY POLICY; LEGAL ASPECTS; ENERGY;ENERGY BALANCE; ENERGY CONSERVATION;ENVIRONMENTAL EFFECTS;NUCLEAR POWER;ELECTRIC POWER;CALIFORNIA;SOLAR POWER PLANTS; GEOTHERMAL ENERGY;USA

273 ENERGY: THE NEW ERA. Freeman, S.D. New York: Halker Publlshing Company, Inc. (1974). 386p. \$12.50. Book: ENERGY;ENUIRONMENTAL EFFECTS; 
GOVERNMENT POLICIES; ENERGY CONSERVATION ; SOLAR

ENERGY ; GEOTHERMAL ENERGY ; THERMONUCLEAR

REACTIONS; ENERGY DEMAND;ENERGY SUPPLIES

274 GEOTHERMAL ENERGY RESEARCH, DEVELOPMENT, AND DEMONSTRATION ACT OF 1974 . SUBMI TTED BY MR. TEAGUE, COMMITTEE ON SCIENCE AND

ASTRONAUTICS, TO THE HOUSE OF REPRESENTATIVES, NINETY-THIRD CONGRESS, SECOND SESSION.

Washington, DC; Committee on Sclence and Astronautles (1974). 41p. GPO. GEOTHERMAL ENERGY;LAWS; LEGAL ASPECTS; RESEARCH PROGRAMS;ECONOMICS;ELECTRIC POWER; POWER GENERATION;GEOTHERMAL ENERGY $R$ D AND D ACT

275 PROJECT INDEPENDENCE. A PROPOSED PROGRAM FOR U.S. ENERGY SELF-SUFFICIENCY BY 1980. Washington, DC; Federal Energy Office (1974). 110p.

ENERGY; USA; ENERGY BALANCE; COAL ; PRODUCTION PETROLEUM; NATURAL GAS;SYNTHETIC FUELS; SHALE OIL; NUCLEAR POWER; GEOTHERMAL ENERGY; ENERGY CONSERVATION;RESEARCH PROGRAHS;ENVIRONMENTAL EFFECTS; PERSONNEL; INTERNATIONAL AGREEMENTS; ENERGY POLICY;PROJECT INDEPENDENCE

276 ENERGY IN OKLAHOMA. VOLUME ONE. FINAL REPORT OF OKLAHOMA ENERGY ADVISORY COUNCIL, FEBRUARY 1, 1974. Oklahome CIty, OK; Oklahoma Energy Advi sory Councli (1974). 49p. Governor's Office, Oklahoma City, OK. ENERGY; OKLAHOMÁ;ENERGY POLICY;ENERGY CONSERVATION;ENVIRONMENTAL EFFECTS; RECOMMENDATIONS ; INFORMATION; COMBUSTION HEAT; NATURAL GAS; FORECASTING;ELECTRICITY; TRADE: PETROLEUM ; USA; LEASES ; REGULATIONS ; EXPLORATI ON ; TAXES; NUCLEAR FUELS; SYNTHETIC FUELS;CAPITAL; HYDROELECTRIC POWER; VIND POWER;GEOTHERMAL ENERGY;SOLAR ENERGY

277 ENERGY LEGISLATION, REPORT OF THE SUBCOMMITTEE ON ENERGY OF THE COMMITTEE ON SCIENCE AND ASTRONAUTICS, U.S. HOUSE OF REPRESENTATIVES, NINETY-THIRD CONGRESS, SECOND SESSION. Washington, DC; Committee on Sclence and Astronautics (1974). 23p.

LEGISLATION;ENERGY POLICY;ALASKA OIL PIPELINE; PETROLEUM; ALLOCATIONS;ENERGY CONSERVATION;REGULATIONS ; GOVERNMENT POLICIES; TRANSPORTATION SYSTEMS ; ENVIRONMENTAL EFFECTS; LAND USE; SURFACE MINING;SI TE SELECTION;OIL SPILLS;WASTE DISPOSAL; COAL; DEEP WATER OIL TERMINALS;NUCLEAR ENERGY;SOLAR ENERGY; GEOTHERMAL ENERGY; ENERGY

278 GEOTHERMAL POWER ECONOMICS: AN ANNOTATED BIBLIOGRAPHY E El-Ramly, N.; Peterson, R.: Seo, K.K. Honolulu, HI; Unlversity of Hawall, Hawall Geothermal Project (1974). 80p. GEOTHERMAL ENERGY;ECONOMICS;HALAI I;

BI BLIOGRAPHI ES; ENV IRONMENTAL EFFECTS ; GOVERNMENT POLICIES

279 PRELIMINARY REPORT ON LEGAL AND PUBLIC POLICY SETTING FOR GEOTHERMAL RESOURCE DEVELOPMENT IN HAWAII. KanIns, R.: Kornrelch, D.; Sheets, G. Honolulu, HI; UnIversity of Haweli (1974). 42p.

GOVERNMENT POLICIES :GEOTHERMAL RESOURCES ; HAWAI ; ECDNOMICS; REGULATIONS ; TAXES ; LEGISLATION ; GEOTHERMAL ENERGY

280 GEOTHERMAL ENERGY EXPLORATION, RESEARCH, AND DEVELOPMENT. REPORT OF THE COMMITTEE ON INTERIOR AND INSULAR AFFAIRS, UNITED STATES SENATE, NINETY-THIRD CONGRESS, SECOND SESSION
TO ACCOMPANY S. 2465. Washington, DC; Committee on Interior and Insular Affairs (1974) 13p.

ENERGY POLICY;GOVERNMENT POLICIES; GEOTHERMAL ENERGY ; LEGISLATION ; F INANCING ; GEOTHERMAL EXPLORATION;COST

281 ENERGY IN TEXAS, VOLUME II. POLICY ALTERNATIVES. Austin, TX; University of Texas (1974). 133p. DIrector of Publications, LBJ School of Public Affairs, Univ. of Texas, Austin, TX $78712 \$ 3.50$.

TEXAS : ENERGY SOURCES: ENERGY POLICY, ALLOCATIONS;ENERGY SUPPLIES; ENERGY DEMAND; DEMAND FACTORS;ENERGY CONSERVATION; LAND USE; WATER RESOURCES ; PLANNING ; MANAGEMENT ; FORECASTING; WIND POWER;GEOTHERMAL ENERGY;COAL; SOLAR ENERGY; NUCLEAR ENERGY;OIL SANDS; SOLID WASTES

282 IMPACTS OF ENERGY RESOURCES REMOVAL FROM FEDERAL AND INDIAN LANDS. Wayland, R.G. Pp Paper 3.2-7, 13p. of 9th world energy conference. London; World Energy Conference (1974).

NATIONAL ENUIRONMENTAL POLICY ACT:ENERGY SOURCES ; RECOVERY ; LEGISLATION ; LAND USE; LAND RECLAMATI ON ; REGULAT IONS ; MINERALS ; ENUIRONMENTAL IMPACTS;LEASES; OIL WELLS ; SITE SELECTION; HATER RESOURCES; NATURAL GAS WELLS; EXPLORAT IDN;COAL MINING; PUBLIC RELATIONS; GROUND WATER; GEOTHERMAL HELLS;OIL SHALES; SHALE OIL;ECONOMICS; INDIAN LANDS; PUBLIC LANDS;ENERGY SOURCE DEVELOPMENT

283 SUMMARY GUIDE TO THE INSTITUTIONAL PROBLEMS CONFRONTING THE GEOTHERMAL ENERGY INDUSTRY. FInn, D.X. PP 218-221 of Geothermal world directory. Meadows, K.F. (comp. and ed.). Glendora, Callfornia; Katherine F. Headows (1974).

From Geological Soclety of America and Soclety of Economic Geologists annual meeting; Miami, Florida ( 18 Nov 1974 ).

TAXES ; GEOTHERMAL ENERGY ; INDUSTRY; LEGAL ASPECTS; LEGI SLATION; POWER POTENTIAL; INSTITUTIONAL BARRIERS

284 GEOTHERMAL RESOURCES. HEARINGS BEFORE THE SUBCOMMITTEE ON WATER AND POWER RESOURCES OF THE COMMITTEE ON INTERIOR AND INSULAR AFFAIRS, UNITED STATES SENATE, NINETY-THIRD CONGRESS, FIRST SESSION ON THE POTENTIAL FOR THE PRODUCTION OF POWER FROM GEOTHERMAL RESOURCES. Washington, DC; Commlttee on Interlor and Insular Affal rs (1974). 485p. GPO.

GEOTHERMAL RESOURCES;ELECTRIC POWER;LEGAL ASPECTS ; RECOMMENDATIONS ; PLANNING ; GEOTHERMAL VELLS; GEOTHERMAL POWER PLANTS;HEARINGS;USA: POWER POTENTIAL; GEOTHERMAL ENERGY; GEOTHERMAL. EXPLORATION

285 ENUIRONMENTAL PLANNING FOR THE GEOTHERMAL LEASING PROGRAM ON PUBLIC LANDS. Stone, R.T.; Frlz, T.0.: Carlson, D.W. (Dept. of the Interlor, Washington, DC). AIChE symp. Ser.: 70: No. $136,777-781(1974)$.

LAND LEASING; GEOTHERMAL RESOURCES; ENUIRONMENTAL IMPACTS; PUBLIC LANDS

286 ULTIMATE FUTURE OF THE GEOTHERMAL ENERGY LAW. Sheets, G.M. Geothern. Energy Mag.; 2: No. 3, 59-61(i974). GEOTHERMAL ENERGY : LEGISLATION; EXPLOITATION

287 PROJECT INDEPENDENCE REPORT .

Washington, DC; Federal Energy Administration (1974). 361P. GPO $\$ 8.35$, Stock Number 4116- 
00029.

ENERGY SOURCES; AVAILABILI TY; HEARI NGS; PROJECT INDEPENDENCE ; LEGISLATION ; ENERGY POLICY; PETROLEUM; NATURAL GAS; COAL;NUCLEAR FUELS; ELECTRICITY;OIL SHALES;SYNTHETIC FUELS;SOLAR ENERGY ; GEOTHERMAL ENERGY ; ENERGY CONSERVATION; ENERGY DEMAND; MANAGEMENT; ENVIRONHENTAL EFFECTS; BUILDING MATERIALS; METALS;CONSTRUCTI ON :

FABRICAT ION; ECONOMICS; WATER RESOURCES; SECURITY

288 PROJECT INDEPENDENCE BLUEPRINT: FINAL TASK FORCE REPORT. GEOTHERMAL ENERGY. Washington, DC; Federal Energy Administration (1974). vp. GPO $\$ 2.00$, S tock Number 411800011 .

GEOTHERMAL ENERGY ; AVAILAB ILITY ; PROJECT INDEPENDENCE;PLANNING;ENERGY POLICY;ECONOMIC POLICY ; PRODUCT ION; FORECAST ING;ECONOMICS

289 ENERGY FROM GEOTHERMAL RESOURCES. REPORT PREPARED FOR THE SUBCOMMI TTEE ON ENERGY OF THE COMMI TTEE ON SCIENCE AND ASTRDNAUTICS, U.S. HOUSE OF REPRESENTATIVES, NINETY-THIRD CONGRESS, SECOND SESSION. DOUman1, G.A.; Riva, J.P.; Mielke, J.E.; Dyas, N.W.; Justus, J.R. Hashington, DC; U.S. House of Representatives, Committee on Sclence and Astronautics (1974). $88 \mathrm{p}$. GEOTHERMAL ENERGY;GEOTHERMAL RESOURCES; GEOTHERMAL POHER PLANTS;REVIEWS

290 GOVERNMENTAL LEASING REGULATIONS. Stone, R.T. (Dept, of the Interior, Washington, DC). Pp 89-90 of Proceedings of a symposium on geotheraal energy and Colorado. Pearl, R.H. (ed.). Denver; Colorado Geological Survey (1974). GEOTHERMAL RESOURCES; LEASES; REGULATIONS; GOVERNAENT POLICIES ; LEGAL ASPECTS; LAND LEASING

\section{GEOTHERMAL RESOURCES: LEGAL AND TAX} CONSIDERAT IONS. Burton, W.A. Jr. (Chevron 0 il Co., Denver). PP 71-78 of Proceedings of a symposium on geothermal energy and Colorado. Pearl, R.H. (ed.). Denver; Colorado Geologlcal Survey (1974).

GEOTHERMAL RESOURCES; LEGAL ASPECTS : MANAGEMENT ; T AXES ; REGULATIDNS ; LAUS ; GOVERNMENT POLICIES

292 RULES AND REGULATIONS RELATING TO GEOTHERMAL LEASES ON COLORADO STATE OUNED LANDS. Bretz, T.E. (Colorado state Board of Land Commissioners, Denver). Pp 91-96 of Proceedings of a symposium on geothermal energy and Colorado. Pearl, R.H. (ed.). Denver; Colorado Geological Survey (1974). COLORADO; GEOTHERMAL RESOURCES;REGULATIONS ; LAND LEASING;GOVERNMENT POLICIES;PUBLIC LANDS

\section{UTILITY PARTICIPATION IN A GEOTHERMAL}

ENERGY SOURCE. Landers, W.S. (Public Service Co. of Colorado, Denver). pp 79-81 of Proceedings of a symposi um on geothermal energy and Colorado. Pearl, R.H. (ed.). Denver; Colorado Geological Survey (1974).

GEOTHERMAL POWER PLANTS;OPERATION ; FINANCING : PLANNI NG; INDUSTRY; ECONOMICS; MANAGEMENT; INVEST MENT ; CAPIT AL;ECONOMIC DEVELOPMENT: GEOTHERMAL ENERGY; PUBLIC UTILITIES

\section{U. S. ENERGY R AND D: POLICY AND} PRIORITIES. Heinberg, A.M. (Federal Energy Administration, Office of Energy Research and Development, Hashington, DC). Pp 18-23 of Energy $R$ and $D$ present and future. Washington, DC; Government Institutes Inc.

\section{(1974).}

From Flrst annual energy $R$ and $D$ conference; Washington, DC (Jun 1974).

ENERGY;ENERGY POLICY;RESEARCH PROGRAMS; GOVERNMENT POLICIES ; LEGISLATION; ENERGY SOURCES: SOLAR ENERGY;GEOTHERMAL ENERGY ; BREEDER REACTORS; ENUIRONMENTAL EFFECTS

295 ENERGY, VOLUME I, DEMANDS, RESOURCES, IMPACT, TECHNOLOGY, AND POLICY, Penner, S.S.: Icerman, L. Reading, MA; Addi son-Wesley Publi shing Company, Inc. (1974). 393p. $\$ 14.50$.

Book; complation of lecture notes. ENERGY DEMAND;ECONOMIC POLICY;ENERGY SOURCES: ENVIRONMENTAL EFFECTS;ENERGY POLICY;ENERGY SUPPLIES ; MARKET ; ENERGY CONSUMPTION; NUCLEAR FUELS;RESERVES; NATURAL GAS;ELECTRICITY; POWER GENERATION; FLYWHEELS ; COAL; FUEL CELLS ; SOLAR ENERGY;HIND POWER;PHOTOVOLTAIC CELLS; HYDROELECTRIC POWER; GEOTHERMAL ENERGY

296 GEOTHERMAL LAWS AND REGULATIONS IN THE WESTERN UNITED STATES, Anderson, D.N. (ed.). (Californla State, Division of 011 and Gas). pp 697-705 of Geothermal Resources. Part I and II. Washington, DC; Committee on Interior and Insular Affalrs (1974).

GEOTHERMAL ENERGY; REGULATIONS; LEGISLATIDN; HAUAII ; ALASKA ; GEOTHERMAL RESOURCES; ARI ZONA; CALIFORNIA ; COLORADO ; IDAHO; MONT ANA ; NEVADA ; NEW MEXI CO; OREGON ; UTAH; WASHINGTON ; HYOMING; ENERGY POLICY

297 GEOTHERMAL RESOURCES. PARTS I AND II. HEARINGS BEFORE THE SUBCOMMITTEE ON WATER AND POWER RESOURCES OF THE COMMITTEE ON INTERIDR AND INSULAR AFFAIRS, UNITED STATES SENATE, NINETY-THIRD CONGRESS, FIRST SESSION.

Washington, DC; Committee on Interlor and Insular Affairs (1974). $771 \mathrm{p}$.

GEOTHERMAL ENERGY;GEOTHERMAL RESOURCES; ELECTRIC POWER; HEATING; GOVERNMENT POLICIES; IDAHO ; ORE GON ; UTAH ; HEARINGS ; GEOTHERMAL HEATING; GEOTHERMAL ENERGY CONVERSION

298 PROJECT INDEPENDENCE BLUEPRINT:

TRANSCRIPT OF SEVENTH PUBLIC HEARING, HOUSTON, TEXAS, SEPTEMBER 16--20, 1974. Washington, DC; Federal Energy Administration (1974). 701p. GPO \$7.35, stock No. 041-018-0053.

PROJECT INDEPENDENCE; HEARINGS; TEXAS ; ENERGY POLICY;ENERGY SOURCES;RESERVES;FOSSIL FUELS; RESOURCES ; SOLAR ENERGY; GEOTHERMAL ENERGY

299 IMPACT OF STATE AND FEDERAL LAW ON DEVELOPMENT OF GEOTHERMAL RESOURCES IN TEXAS. Edwards, T. Austin, TX; State of Texas Governor's Energy Advisory Councli (1974). 53p. Legal and Regulatory Polley Committee, P.O. Box 12548, Capitol Station, Austin, TX 78711 .

GEOTHERMAL ENERGY;REGULATIONS;ENERGY POLICY; LAWS; LEGAL ASPECTS; TEXAS ; CAPITAL;BY-PRODUCTS; AVAILABILITY; WATER RESOURCES ; GEOLOGICAL SURVEYS; EXPLORATI ON; OVERBURDEN ; METHANE ; RECOVERY; AGRI CULTURE; INDUSTRY

300 GEOTHERMAL ENERGY RESEARCH, DEVELOPMENT, AND COMMERCIAL DEMONSTRATION ACT OF 1973; GEOTHERMAL ENERGY RESEARCH, DEVELOPMENT, AND DEMONSTRATION ACT OF 1974. HEARINGS BEFORE THE SUBCOMMITTEE ON ENERGY OF THE COMMITTEE ON SCIENCE AND ASTRONAUTICS, U.S. HOUSE OF REPRESENTATIVES, NINETY-THIRD CONGRESS, SECOND SESSION ON H.R.11212 AND H.R.14172.

Washington, DC; Committee on Science and Astronautics (1974). 544p. 
GEOTHERMAL ENERGY;RESEARCH PROGRAMS :

GOVERNMENT POLICIES ; LEGISLAT ION; ENERGY POLICY; FINANCING; GEOTHERMAL ENERGY R D AND D ACT: HEARINGS

301 STATE RESPONSES TO THE ENERGY CRISIS. Lexington, KY; Councll of State Governments (1974). 44p. The Councll of state Governments, Iron Works PIke, Lexington, KY $40511 \$ 3.00$.

ENERGY CONSERVATION;ENERGY SOURCES; ALLOCATIONS ; FORECAST ING ; USA ; LEGISLATION SECURITY;NAT IONAL DEFENSE; GOVERNMENT POLICIES ; PETROLEUM; MARKET ; GASOLINE; EFFICIENCY; BIBLIOGRAPHIES;ENERGY POLICY;WATER RESOURCES : ELECTRICITY; NUCLEAR POWER;GEOTHERMAL ENERGY; ENVIRONMENTAL EFFECTS

302 DEVELOPMENT OF GEOTHERMAL LAHS AND REGULATIONS. Aldlin, J.W. PP vp. of Geothermal regulations. Davis, CA: Geothermal Resources Councli (1974).

State statutes and regulations, federal Geothermal Steam Act. GEOTHERMAL ENERGY; REGULAT I ONS ; LAHS ; ALASKA; ARIZONA ; CALI FORNIA ; COLORADO; HAWAII; IDAHO; MONTANA ; NEVADA ; NEW MEXICO; OREGON ; UTAH; WASHINGTON ; WYOMI NG ; TAXES

303 FEDERAL REGULATIONS AND LEASE TERMS AND THEIR REGULATIONSHIP TO STATE LAWS AND REGULATIONS, Conover, R.D. (Dept of Interlor, Riverside, $C A$ ). $P P$ vP. of Geothermal regulations. Davis, CA; Geothermal Resources Council (1974). REGULAT IONS ; LAND LEASING; GEOTHERMAL RESOURCES ; WATER ; ENUIRONMENT ; RESOURCE CONSERUATION ; LAHS

304 A BRIEF OUTLINE OF GEOTHERMAL REGULATORY AGENCIES IN THE WESTERN UNITED STATES. PP VP. of Geothermal regulations. $v$. Davis, CA Geothermal Resources Council (1974).

USA;REGULATIONS;US ORGANIZATIONS;ALASKA; GOUERNMENT POLICIES;ARIZONA; CALIFORNIA;COLORADO: IDAHO; MONT ANA; NEW MEXICO;NEVADA; OREGON ; UTAH; WASHINGT ON ; WYOMING; GEOTHERMAL RESOURCES; ENFORCEMEN T

305 SELECTED PORTIONS OF CALIFORNIA STATEWIDE GEOTHERMAL REGULATIONS. APPENDIX B. PP 33-49 of Geothermal regulations. Davis, CA; Geothermal Resources Councll (1974).

CALIFORNIA;REGULATIONS; GOVERNMENT POLICIES ; GEOTHERMAL RESOURCES;LEGAL ASPECTS; WELL DRILLING;WELL CASINGS; BLOWOUTS;DRILLING FLUIDS; BOREHOLES; GEOTHERMAL HELLS

306 EIR'S: TRUTH AND CONSEQUENCES. Taft, M.I.: Feffer, A.P. (Socio-Economic Systems, Inc., Los Angeles). Pp vp. of Geothermal regulations. Davis, CA; Geothermal Resources Counc1 1 (1974).

Legisiation, status, and recommendations for geothermal development. ENUIRONMENTAL IMPACT STATEMENTS ; LEGISLATION ; GEOTHERMAL RESOURCES; ENVIRONMENT; SOCIOLOGY;ECONOMICS; LAND USE; REGULATIONS

307 PGANDE'S GEOTHERHAL POWER PLANT IN CALIFORNIA: THE GEYSERS. HOWE, H. PP vP. of Geothermal regulations. Davis, CA; Geothe rmal Resources Council (1974). GEYSERS GEOTHERMAL FIELD; GEOTHERMAL POWER PLANTS ; POWER GENERATION; POWER POTENTIAL; NATURAL STEAM : DESIGN ; OPERATION ; COST ; REGULATIONS ; ENUIRONMENTAL EFFECTS;ELECTRIC POWER
308

GEOTHERMAL WELL DRILLING AND COMPLETION PRACTICES IN CALIFORNIA INCLUDING CASING AND ABANDONMENT PROGRAMS AND EXAMPLES OF BLOWOUTS. PP vP. of Geothermal regulations. Campbell, G.E. Davis, CA; Geothermal Resources Council (1974).

GEOTHERMAL WELLS; WELL DRILLING; CALIFORNIA: WELL CASINGS ; BLOWOUTS ; BOREHOLES; VAPOR-DOMINATED SYSTEMS;HOT-WATER SYSTEMS;SITE SELECTION; IMPERIAL VALLEY; DIAGRAMS; EQUIPMENT ; REGULATIONS

309 WHY PUBLIC POLICY MUST SUPPORT GEOTHERMAL DEVELOPMENT. Brewer, $W$. PP 226-227 of Multipurpose use of geothermal energy. Lienau, P.J.: Lund, J.W. (eds.). Klamath Falls, OR; Oregon Inst. of Tech. (1974). It is pointed out that, except for a few unusually attractive locations, the geotheral potential of the western states still remains largely unknown, unexplored, and difficult to get covered in effective development prograns. The need to get public policy and public money behind sizeable prograns keyed to utilization of new technology - just as fast as it develops - Is emphasized. (LS)

310 RECENT DEVELOPMENTS IN THE TAXATIDN OF GEOTHERMAL EXPLORATION. El senstat, S.M. (Geothermal Exploration Co., New York). 238-239 of Multipurpose use of geothernal energy. Llenau, P.J.: Lund, J.W. (eds.). Klamath Falls, OR; Oregon Inst, of Tech.

(1974).

The question of whether the provisions of the Internal Revenue Code relating to oil and gas, which permit the expensing of intanglble drililing costs and provide the depletion allowance, apply to geothermal exploration is discussed. Proposed legislation that was to have been considered by Congress is discussed. (LS)

311 PERSPECTIVE FOR THE 94TH CONGRESS. Hall, L.K. PP 228-237 of Multlpurpose use of geothermal energy. Llenau, P.J.: Lund, J.W. (eds.). Klamath Falls, OR; Dregon Inst. of Tech. (1974).

Some of the congressional interests and leglisiation related to energy research and funding a re outlined. The conclusions and recommendations of the Task Force on Energy of the House Committee of Science and Astronautics are given. (LS)

312 ECOMOMICS OF GEOTHERMAL EXPLORATION Reed, M.J. (comp.). pp 12-14 of Geothermal power economics: an annotated bibllography. El-Ramly, N. (ed.). Honolulu, Hawali; Univ. of Hawall (1974).

GEOTHERMAL EXPLORATION;ECONOMICS; COST; LEGAL ASPECTS; CALIFORNIA; BIBLIOGRAPHITES

313 WATER AND POWER FROM GEOTHERMAL RESOURCES IN CALIFORNIA, AN OVERUIEW. White, C.R.; Yates, P.J. Sacramento, CA; Callfornia Dept. of Water Resources (1974). 60p.

Information is included on the physical characteristics of the different types of development methods and problems, environmental concerns, and legal and institutional aspects. Because the legal and institutional aspects are becoming increasingly significant, more detalled study of the discussion is included in an appendix. (MHR)

314 ENERGY TAXES AND SUBSIDIES . Brannon, G.M. Cambridge, MA; Ballinger Publishing Co. 
(1974). 189p.

This study deals with sensitive and difficult questions of public policy. and subsidies are anong the most powerful tools avaliable to government in shaping the nation's energy and economic future. Decisions to establish, change or retaln various tax provisions or subsidy programs can have profound Impacts on energy prices, growth rates, production and consumption patterns, income levels and distributions, and international trade patterns. All of these subjects are treated with vigor along with the current concerns for pollution abatement in the envi ronment. (PCS)

315 PROCEEDINGS OF THE WORKSHDP ON ENVIRONMENTAL ASPECTS OF GEOTHERMAL RESOURCES DEVELDPMENT, 20--22 SEPTEMBER 1974. Anderson, D.N.: Bowen, R.G. Sacramento, CA; Callfornia State Dept. of Conservation (1974). 126p. (PB--245209). NTIS.

The purpose of this conference was to identify the environmental degradation related to the use of geothermal resources to produce electricity and, if possible, suggest

directlons for research to mitigate these problems. Six work groups were establlshed: Hater Quality, Alr Quallty, Blologlcal Impact, Hazards, Environmental Impact Evaluation, and Land Use and Socio-Economic Impact. A chairman's summary, problems, and recommended approaches to solution are presented in each area. In sumary, those who urge rapid development of geothermal resources as a group realize that there are environmental costs, but feel the overall impact is auch less per unit of power than the Impact of conventional and nuclear sources. Kany of those urging caution and restraint in the development of geothermal energy realize that the environmental impact is less than most other power sources but feel by their efforts geotheral conversion can be nade even cleaner.

316 ENERGY REGULATION BY THE FEDERAL POWER COMMISSION. Breyer, S.G.; Macavoy, P.W. Hashington, DC; Brookings Institution (1974). $173 p$.

The authors investigate the three major areas of FPC's work: natural gas pipeline prices, natural gas fleld prices, and electricity production. They conclude that the Conmission helped nel ther the consumer nor industry. They contend that regulation had little effect upon pipeline prices and that it did not signiflcantiy promote a better the Comission kept gas field prices low, in doing so it may have created a shortage that hurt consumers more than low prices helped them. Since the Commlssion's tasks (controlling monopoly power, transferring income from producer to consumer, planning for more efficient production) are typlcal forms of economic regulation, the study has a number of implications regarding the regulatory process in general. These are discussed in the final chapter.

317 Interstate ENUIRONMEntal PROBLEmS: A GUIDE TO WATER POLLUTION AND WATER SCARCITY. Harris, R.W.; Jeffery, W.D.; Stewart, B.W. Jr. Stanford, CA: Stanford Environmental Law Society (1974). 169p. $\$ 4.25$.

Thls book is concerned with environmental problems which originate in one state and spread to another and offers legal and practical information to help a citizen group defend its "environmental rights."' The book is divided into flue chapters. Chapter 1 presents a detalled case study of the Truckee River System in California--Nevada to lllustrate some of the problems and solutions which arise in an interstate setting. Chapters 2 and 3 introduce the legal and technical backgrounds of water scarcity and water pollution: the problems most of ten encountered in interstate environmental disputes. Chapter summarizes the political, administrative, and judicial remedies avallable to private citizens. Chapter 5 outlines the strategles and tactics for waging an effective environmenal campaign. And for those interested in further information, the text is supplemented by nearly five hundred footnotes, four appendices, and a selected blbl lography.

318 DEVELOPMENT OF GEOTHERMAL RESOURCES AND THE 1970 GEOTHERMAL STEAM ACT: LAH IN SEARCH OF DEFINITION. BJorge, K.R. (Northern Kentucky State Coll., Covington). Univ. Colo. Law Rev.; 46: 1-25(1974).

It is submitted that the court erred in U.S. vs Union Dil Company (Callf. 1974), by: (1) falling to find that Congress intended the Stock Ralsing Homestead Act to grant on estate limited to surface use with such subsurface rights as reasonably necessary to serve the purpose of surface ownership, and (2) in inferentially treating geothermal resources as water resources to arrive at the conclusion that geothermal resources were not reserved because water is not a mineral within terms of the Stock Raising Homestead Act. Alternate legal concepts are suggested. (PCS)

319 VICTORY SAND AND CONCRETE, INC. US COMMISSIONER OF . INTERNAL REVENUE, JANUARY 2 , 1974. Tax Court Rep.; 61: 407-424(1974).

Petitloner was engaged in the business of extracting and selling sand and gravel from the Kansas RIver, on a tract of land owned by $1 t$. Sand and gravel in the bed of the river was replenished to some extent by the flow of the river but the quality and quantity thereof was diminishing, particularly after flood control and conservation dams were bulit on the tributaries of the Kansas River upstrean from petitioner's ining area. Held, petitioner had an economic interest in the deposit of sand and gravel in its permit area sufficient to entitle it to percentage depletion deductions produced by its operations. Held, further, the aineral deposit in which petitioner had an economic interest is a wasting asset within the meaning of the depletion statutes.

320 GEOTHERMAL RESOURCES LEASING: GENERAL. Fed. Reglst. (Wash., D.C.): 38: 387-420(21 Dec 1973). (43CFR3200).

These regulations are 1 ssued pursuant to the Geothermal Stean Act of 1970 ( 84 Stat. 1566: 30 USC 1001-1025) and rights to develop and ut1llze geothermal resources in land subject to these regulations may be acquired only in accordance with these regulations.

321 GEOTHERMAL RESOURCES: LEASING DN PUBLIC, ACQUIRED, AND HITHDRAWN LANDS. Fed. Regist. (Wash., D.C.); 38: No. 245, 35068-35073(21 Dec 1973). (30CFR270; 30CFR271).

Text of leasing regulations for public, acquired and withdrawn lands is presented. Regulations became effective January $1,1974$. (PCS)

322 (WASH--1281) UNC1 NATION'S ENERGY FUTURE, A REPORT TO RICHARD M. NIXON, 
PRESIDENT OF THE UNITED STATES. Ray, D.L. (USAEC, Washington, D.C.). 1 Dec 1973. 182p, GPO \$1.95.

ENERGY; REVIEWS; ECONOMICS; ENVI RONMENT ; NUCLEAR POWER; FOSSIL FUELS ; INDUSTRY;USA; ENERGY CONSERVATION ; NATURAL GAS ; PETROLEUM; COAL; RESEARCH PROGRAMS; SOLAR ENERGY;GEOTHERMAL ENERGY ; UIND; ENERGY POLICY

323 (PB--237045) UnCI CALIFORNIA ENERGY WORKSHOP: DEVELOPING A PLAN OF ACTION TO MEET THE ENERGY CRISIS IN CALIFORNIA. JebIns, A.B. (California State Office of Sclence and Technology, Sacramento (USA)). Dec 1973. 52p. NTIS $\$ 4.25$.

CALIFORNIA;ENERGY POLICY; ENERGY DEMAND ENERGY CONSUMPTION;GOVERNMENT POLICIES;ENERGY SOURCES; NUCLEAR POWER; GEOTHERMAL ENERGY; PLANNI NG

324 THE POTENTIAL FOR ENERGY PRODUCTION FROM GEOTHERMAL RESOURCES: REPORT OF THE SUBCDMMITTEE ON WATER AND POWER RESOURCES, COMMITTEE ON INTERIOR AND INSULAR AFFAIRS, UNITED STATES SENATE, NINETY-THIRD CONGRESS, FIRST SESSION. Washington, DC: Comnittee in Interlor and Insular Affairs (Dec 1973). 40p. GPO $\$ 0.50$.

GEOTHERMAL ENERGY;GEOTHERMAL RESOURCES; VAPORDOMINATED SYSTEMS; HOT-WATER SYSTEMS;HOT-DRYROCK SYSTEMS; GEOPRESSURED SYSTEMS; RESEARCH PROGRAMS; ENVIRONKENTAL EFFECTS;ENERGY POLICY; GOVERNMENT POLICIES; LEGISLATION; POUER POTENTIAL; ECONOMICS

325 (WASH--1281-8) UnCl GEOTHERMAL ENERGY PROGRAY. SUBPANEL REPORT VIII USED IN PREPARING THE AEC CHAIRMAN'S REPORT TO THE PRESIDENT. (USAEC, Washington; D.C.). 13 Nov 1973. 192p. Dep. NTIS \$12.75.

GEOTHERMAL ENERGY;RESEARCH PROGRAMS ; BUDGETS; BRINES;ROCKS; GEOLOGIC DEPOSITS;PILOT PLANTS; EXPLORAT ION; ENUIRONMENT ; LEGAL ASPECTS;ELECTRIC POWER; HEAT;GEOTHERMAL RESOURCES;GEOTHERMAL POWER PLANTS

326 (EIS-CA--73-1681-F-1) UnCl GEOTHERMAL LEASING PROGRAM. VOLUME I. PROMULGATION OF LEASING AND OPERATING REGULATIONS. FINAL ENVIRONMENTAL IMPACT STATEMENT. (Department of the Interlor, Hashington, D.C. (USA)). 24 Oet 1973. 519p. NTIS $\$ 1.45$.

REGULAT IONS; ENVIRONMENTAL IMPACT STATEMENTS; LAND LEASING;GEOTHERMAL RESOURCES;GEOTHERMAL EXPLORAT ION; CALIFORNIA ; ENERGY CONSUMPTION

327 (EIS-CA-73-1681-F-2) UnCl GEOTHERMAL LEASING PROGRAM. VOLUME II. LEASING OF GEOTHERMAL RESOURCES IN THREE CALIFORNIA AREAS. FINAL ENVIRONMENTAL IMPACT STATEMENT. (Department of the Interior, Washington, D.C. (USA)). 24 Oct 1973.547 . NTIS $\$ 1.45$. Clear Lake, Mono Lake, Imperial Valley. GEOTHERMAL RESOURCES;LAND LEASING; CALI FORNIA; ENVIRONMENTAL IMPACT STATEMENTS; IMPERIAL VALLEY; GEOTHERMAL EXPLORATION

328 (EIS-CA--73-1681-F-3) UnCl GEOTHERMAL LEASING PROGRAM. VOLUME III. APPENDICES A THROUGH H. PROPOSED GEOTHERMAL, LEASING, AND OPERATING REGULATIONS. FINAL ENVIRONMENTAL IMPACT STATEMENT. (Departaent of the Interlor, Washington, D.C. (USA)). 24 Oct 1973. 701P. NTIS $\$ 1.45$. GEOTHERMAL RESOURCES; LAND LEASING; REGULATIONS; PUBLIC LANDS;USA ; CALIFORNIA; ENVIRONMENTAL IMPACT STATEMENTS
329 (EIS-CA--73-1681-F-4). Uncl GEOTHERHAL LEASING PROGRAM. VOLUME IV. APPENDIX I. COMMENTS ON DRAFT IMPACT STATEMENT AND PROPOSED REGULATIONS. FINAL ENVIRONMENTAL IMPACT STATEMENT. (Department of the Interior, Washington, D.C. (USA)). 24 Oct 1973. 728p. NTIS $\$ 1.45$.

LAND LEASING; GEOTHERMAL RESOURCES; ENVIRONMENTAL IMPACT STATEMENTS:CALIFORNIA: REGULATIONS; IMPERIAL VALLEY;USA

330 (AD--778886) UnC1 ENERGY CRISIS: REVISION IN U.S. POLICY TO PRESERVE NATIONAL SECURITY. Duffett, J.W. (Aray War Coll Carlisle Barracks, Pa. (USA)). 22 Dct 1973. 32p. NTIS $\$ 4.75$.

ENERGY POLICY;USA; AVAILABILITY; SECURITY; ENERGY SOURCES;ENERGY DEMAND;COAL; PETROLEUH; NATURAL GAS;HYDROELECTRIC POWER; NUCLEAR ENERGY; OIL SHALES; UIND POWER;TIDAL POWER; GEOTHERMAL ENERGY ; ENERGY CONSERVAT ION ; INTERNATIONAL AGREEMENTS;NATIONAL DEFENSE; ENERGY SHORTAGES

331 FEDERAL TAX POLICY AND GEOTHERMAL ENERGY DEVELOPMENT. Finn, D.F.X. Geotherm. Energy Kag. : 1: No. 3, 39-42( Oct 1973).

LEGAL ASPECTS ; GEOTHERMAL. ENERGY; EXPLORATION; PLANNING;ECONOMICS; PRODUCTION; NATURAL GAS; PETROLEUM:COAL;URANIUM ORES; GEOLOGY;TAXES; GOVERNMENT POLICIES

332 ENERGY CRISIS AND THE CONSUMER STATES. DFeehan, J.G. (Malne Public Utllities Commission, Augusta). Nat. Res. Lawyer; 6: No. 4, 495-502(Fal 1973).

From Annual neeting of the Natural Resources Law Section, American Bar Assoclation; Washington, DC (7 Aug 1973).

INCOME ; CHARGES ; ECONOMICS; ENERGY SOURCES; ENERGY POLICY; ENERGY CONSUMPTION; PRODUCTION; NUCLEAR ENERGY; POPULATION DYNAMICS; FOSSIL FUELS; DISTRIBUTION; SOLAR ENERGY; GEOTHERMAL ENERGY; ENVIRONMENTAL EFFECTS

333 ENERGY POLICY INTERACTIONS IN THE UNITED STATES. Smernof, B.J. (Hudson Inst., Inc., NY). Energy Polley; 1: No. 2, 136-153(Sep 1973 ).

ENERGY POLICY ; FOSSIL FUELS: ECONOMICS : SOLAR ENERGY;GEOTHERMAL ENERGY;BREEDER REACTORS; USA

334 TAX TREATMENT OF EXPLORING AND DEVELOPING GEOTHERMAL RESOURCES EIsenstat, S.M. OII and Gas Tax Quart of 22: 76-81(Sep 1973). Exploration and development of geothermal resources should be subject to the sane tax treatment as exploration and development of ofl and gas.... To permit certain tax treatment where the geothermal resource is steam and to deny comparable treatment when the resource is superheated water Is without basis. (PCS)

335 (NSF/RA/N--73-117(Vol.2)) Uncl PROCEEDINGS: NATIONAL CONFERENCE ON GEOTHERMAL ENERGY, PALM SPRINGS, CALIFORNIA, MAY 10--11, 1973. VOLUME II. Leh, Mo (ed.).

(Callfornia Univ. Riverside (USA)). Aug 1973. vp. (CONF-7305117--P2). Unive of Callernia, Riverside.

From National conference on geothermal energy: Palm Springs, Callfornia, USA (10 May 1973).

GEOTHERMAL ENERGY; MEETINGS; LEGAL ASPECTS

336 HAHAII VOLCANO ENERGY. Sheets, G.H. Geotherm. Energy Mag.; 1: No. 1, 23-24(Aug 
$1973)$.

VOLCANOES ; GEOLOGY ; GEOTHERMAL ENERGY ; LEGAL AS PECTS; HAWAII ; REGULAT IONS ; EXPLORATION; GEOTHERMAL RESOURCES

337 GEOTHERMAL EXPLORATION ON PUBLIC LANDS: WHEN AND UNDER WHAT CONDITIONS. BOwen, R.G. Geotherm. Energy Mag - 1: No. 1, 25-26(Aug 1973).

USA. GEOTHERMAL ENERGY; LAND LEASING: GEOTHERMAL EXPLORATION;ENERGY SOURCES; LEGAL ASPECTS; USA; GEOTHERMAL RESOURCES;PUBLIC LANDS

338 GEOTHERMAL: THE PROBLEM OF DEFINITION. Sunners, W.K. Geotherm. Energy Mag.: 1: No. 1. 29-33 (Aug 1973).

GEOTHERMAL ENERGY;LEGAL ASPECTS;ELECTRIC POHER: LEGAL DEF INITIONS

339 DINNER SESSION, THURSDAY, 10 MAY 1973. Fannin, P.J. (US Senator, Arizone). pp 4757 of Proceedings of National Conference on Geothernal Energy, May 10-11, 1973, Palm Springs, Callfornia. Volume 1. Leh, M. (ed.). Riverside: Univ. Calif. (Aug 1973). From National Conference on Geothermal Energy: Paln Springs, $C A(10-11$ May 1973). National Conference on Geothermal Energy, Palm Springs, California. GEOTHERMAL ENERGY; MEETINGS ; USA ; ENERGY DENAND;ENERGY SUPPLIES: ENERGY CONSUMPTION;FOSSIL FUELS; NUCLEAR POLER; CALIFORN IA ; ARIZONA; GEOTHERMAL RESOURCES ; LAND LEASING; LEGAL ASPECTS;ENERGY POLICY; GEOTHERMAL WELLS; POUER POTENTIAL; GEDTHERMAL ENERGY CONVERSION; ENUIRONHENTAL EFFECTS;LEGISLATION

340 LUNCHEON SESSION, THURSDAY, 10 MAY 1973. Livernore, N.B., Jr. (Secretary, Resources Agency, State of California). pp 40-5 of Proceedings of National Conference on Geothermal Energy, May 10-11, 1973, Palm Springs, Callfornta. Volume 1. Leh, M. (ed.). RIverside: UnIv. Calif. (Aug 1973). From National Conference on Geothermal Energy: Palm Springs, CA (10-11 May 1973). National Conference on Geothermal Energy, Pala Springs, Calif. USA;CALIFORNIA;ENERGY DEMAND;ELECTRIC POWER;ENERGY CONSUMPTION;FOSSIL FUELS; NUCLEAR POWER; GEOTHERMAL POWER PLANTS: HYDROELECTRIC POWER; GEOTHERMAL ENERGY; POWER POTENTIAL: LAND LEASING;ENERGY POLICY:

ENVIRONMENTAL EFFECTS; MEETINGS

341 AFTERNOON GENERAL SESSION, FRIDAY, 11 MAY 1973. Rigg, J.B., Jr. (Deputy Assistant Secretary-Energy and Minerals, US Dept. Interior). Pp 70-80 of Proceedings of National Conference on Geothermal Energy, May 10-11, 1973, Palm Springs, California. Volume 1. Leh, M. (ed.). Riverside; Univ. Calif. (Aug 1973).

From National Conference on Geothermel

Energy: Palm Springs, CA ( 10-11 May 1973). National Conference on Geothernal Energy, Palm Springs, Cali fornia. USA: GEOTHERMAL RESOURCES ; ENERGY POLICY;FOSSIL FUELS;ECONOHICS : ENERGY CONSERVATION; GEOTHERMAL ENERGY; MEETINGS; LAND LEASING;ENUIRONMENTAL EFFECTS;EXPLOITATION

342 INTERRELATIONSHIP BETHEEN FEDERAL, STATE, AND LOCAL REGULATORY AGENCIES ON THE DEVELOPHENT OF THE GEOTHERMAL RESOURCE IN CALIFORNIA. Cahramen, T.H. (Univ. Calif., Riverside). pp 104-40 of Proceedings of National Conference on Geothermal Energy, May 10-11, 1973, Pal Springs, California. Volume II. Leh, M. (ed.). Riverside; Univ. Calif. (Aug 1973).
From National Conference on Geothermel Energy: Palm Springs, CA (10-11 May 1973). I MPERI AL VALLEY; CALIFORNIA; GEOT HERMAL RESOURCES;EXPLOITATION;LEGAL ASPECTS; GEOTHERMAL ENERGY : REGULATIONS : GEOTHERMAL EXPLORATION ; UELL DRILLING ; ENVIRONMENTAL EFFECTS; LAND LEASING; GEOTHERMAL WELLS ; BOREHOLES ; ENVIRONMENT ; POLLUT ION ; WASTE DISPOSAL ; BRINES; GEOTHERMAL POHER PLANTS;ENVIRONMENTAL IMPACT STATEMENTS; LOCAL GOVERNMENT ; STATE GOVERNMENT

343 FLOW CHART OF CRITICAL PATH IN GEOTHERMAL EXPLORATION. Anderson; D. (DIV. OII and Gas, State of Calif.). pp 141-3 of Proceedings of National Conference on Geothermal Energy, May 10-11, 1973, Palm Springs, Callfornia. Volume II. Leh, M. (ed.). Riverside; Univ. Calif. (Aug 1973). From National Conference on Geotheraal Energy; Palm Springs, CA (10-11 May 1973). GEOTHERMAL EXPLORATION; GEOLOGICAL SURVEYS: GEDCHEMICAL SURVEYS ; GEOPHYSICAL SURVEYS;LAND LEASING ; BOREHOLES ; HELL DRI LLING; GEOT HERMAL WELLS ; OPERAT IDN; GEOTHERMAL POWER PLANTS; SPACE HEAT ING ; MINERALS ; WATER; RECOVERY; REGULATIONS; LEGAL ASPECTS:DIAGRAMS ; USA

344 FEDERAL GEOTHERMAL STEAM ACT OF 1970 : PUBLIC LAW 91-581. Pp 145-53 of Proceedings of National Conference on Geothermal Energy, May 10-11, 1973, Palm Springs, Callfornia. Volume II. Leh, M. (ed.). Riverside: Univ. Calif. (Aug 1973).

From National Conference on Geothermal Energy: Palm Springs, CA (10-11 May 1973). GEOTHERMAL ENERGY; LEGISLATION;USA; LAND LEASING; GEOTHERMAL FLUIDS; LAND USE; WASTE DISPOSAL; PUBLIC LANDS; GEOTHERMAL RESOURCES : GEOTHERMAL STEAK ACT

345 PROPOSED RULE HAKING: GEOTHERMAL RESOURCES - LEASING ON PUBLIC, ACQUIRED AND WITHDRAWN LANDS; REVISION OF PROPOSED RULE. pp 155-71 of Proceedings of National Conference on Geothermal Energy, May 10-11, 1973, Palm Springs, California. Volume II. Leh, M. (ed.). Riverside; Univ. Callf. (Aug 1973). From National Conference on Geothermal Energy: Palm Springs, CA (10-11 May 1973). USA ; GEOTHERMAL RESOURCES; LEGISLATION; PLANNING ; LAND LEASING; GEOTHERMAL FIELDS;LAND USE; GEOTHERMAL EXPLORATION;PUBLIC LANDS

346 GEOTHERMAL RESOURCES - OPERATIONS ON PUBLIC, ACQUIRED AND WITHDRAWN LANDS; NOTICE OF PROPOSED RULEMAKING. PP 172-86 of Proceedings of National Conference on Geothermal Energy. May 10-11, 1973, Palm Springs, Calitornia. Volume II. Leh, M. (ed.). Riverside; Univ. Calif. (Aug 1973).

From National Conference on Geotheraal Energy: Pala Springs, CA (10-11 May 1973). USA; GEOTHERMAL RESOURCES;LAND USE; LEGI SLATI ON; PLANNING;WELL DRILLING; ENUIRONMENTAL EFFECTS; POLLUTION; SAFETY; FINANCING; GEOTHERMAL WELLS; DPERATION; PUBLIC LANDS ; LAND RECLAMATION; REGULATIONS

347 LEASING ON PUBLIC, ACQUIRED AND WITHDRAWN LANDS: REVISION OF PROPOSED RULE. Pp 188-220 of Proceedings of National Conference on Geothermal Energy, May 10-11, 1973, Palm Springs, California. Volume II. Leh, M. (ed.). Riverside; Univ. Calif. (Aug 1973). From National Conference on Geothermal Energy: Palm Springs, CA (10-11 May 1973). USA ; GEOTHERMAL RESOURCES - LAND LEASING; LEGISLATI ON; PLANNING ; GEOTHERMAL EXPLORATION; GEOTHERMAL WELLS; OPERAT I ON ; REGULAT IONS; 
FINANCING; PUBLIC LANDS

348 CALIFORNIA PUBLIC RESOURCES CODE: STATUTES PERTAINING TO GEOTHERMAL RESOURCES. pp 222-49 of Proceedings of Natlonal Conference on Geothermal Energy, May 10-11, 1973, Palm Springs, California. Volume II. Leh, M. (ed.). Riverside: Univ. Callf. (Aug 1973). From National Conference on Geothermal Energy: Pale Springs, CA (10-11 May 1973). CALIFORNIA; GEOTHERMAL RESOURCES;LEGISLATION: PUBLIC LANDS; GEOTHERMAL EXPLORATION; WELL DRILLING; GEOTHERMAL WELLS; OPERATION;ENVIRONMENT; POLLUTION; WASTE MANAGERENT ; F INANCING ; REGULA TIONS; LAWS

349 ADMINISTRATIVE LAHS OF CALIFORNIA'S STATE LAND COMMISSION; REGULATIONS PERTAINING TO GEOTHERMAL RESOURCES. PP 251-8 of Proceedings of National Conference on Geothermal Energy, May 10-11, 1973, Palm Springs, California. Volume II. Leh, M. (ed.). Riverside; Univ. Calif. (Aug 1973).

From National Conference on Geothermal Energy; Paim Springs, CA (10-11 May 1973). CALIFORNI A; PUBLIC LANDS; GEOTHERMAL RESOURCES; LEGISLAT ION; REGULATIONS ; GEOT HERMAL WELLS; WELL DRILLING;OPERAT ION; WASTE MANAGEMENT;GEOTHERMAL EXPLORAT ION; LAND LEASING; LICENSING ; LAWS

\section{ADMINISTRATIVE LAW OF CALIFORNIA'S} RESOURCES AGENCY: PORTION OF THE DIRECTIONS FOR PREPARING ENVIRONMENTAL IMPACT REPORTS. pp 260 of Proceedings of National Conference on Geothermal Energy, May 10-11, 1973, Palm Springs, California. Volume II. Leh, $M$. (ed.). Riverside; Univ. Calif. (Aug 1973). From National Conference on Geothermal Energy; Palm Springs, CA (10-11 May 1973). CALIFORNIA; LEGISLATION;ENVIRONMENTAL IKPACT STATEMENTS;GEOTHERMAL RESOURCES; REGULATIONS

351 TERMS, CONDITIONS, STANDARDS, AND APPLICATION PROCEDURES FOR I NITIAL GEOTHERMAL DEVELOPMENT: IMPERIAL COUNTY, CALIFORNIA. PP 263-82 of Proceedings of National Conference on Geothermal Energy, Kay 10-11, 1973, Paim Springs, Callfornia. Volume II. Leh, M. (ed.). Riverside; Univ. Calif. (Aug 1973). From National Conference on Geothermal Energy: Palm Springs, CA (10-11 May 1973). GEOTHERMAL ENERGY;LEGISLATION ; IMPERIAL VALLEY;GEOTHERMAL RESOURCES; GEOTHERMAL WELLS; WELL DRILLING; OPERAT ION ; FINANCING ; LICENSING; WASTE MANAGEMENT;ENVIRONMENT ; POLLUTI ON;LAND USE; GEOTHERMAL POWER PLANTS; PLANNING ; CALIFORNIA; REGULATIONS

352 MAJORITY OPINION IN THE REICH CASE: QUESTIDN OF DEPLETION. PP 284-301 of Proceedings of National Conference on Geothernal Energy, May 10-11, 1973, Palm Springs, Callfornia. Volume II. Leh, $M$. (ed.). Riverslde; UnIv. Callf. (Aug 1973). From National Conference on Geothermal Energy: Palm Springs, CA (10-11 May 1973). GEOTHERMAL WELLS;OPERAT ION; FINANCING; LEGAL ASPECT S; TAXES;HELL DRILLING; COST; GEYSERS GEOTHERMAL FIELD;NATURAL STEAM; DEPLETION ALLOWANCES

\section{DEPARTMENT OF THE INTERIOR FINAL} STATEMENT. PP 135-40 of Geothermal world directory 1973. Meadows, K.F. (ed.). Glendora, CA: Katherine F. Meadows (Aug 1973). US policy on land leasing for geothermal energy devel opment. USA; GEOTHERMAL FIELDS; LAND LEASING; LEGISLATION; GEOTHERMAL RESOURCES;
MINERALS ; ENVIRONMENT ; MANAGEMENT; GEOTHERMAL EXPLORATION;GOVERNMENT POLICIES

354 IDAHO LEGISLATURE. PP 213-19 of Geothermal world directory 1973. Meadows, K.F. (ed.). Glendora, CA; Katherine F. Meadows (Aug 1973).

IDAHO; GEOTHERMAL RESOURCES; LEGISLATION; REGULATIONS; LEGAL ASPECTS; GEOTHERKAL EXPLORATION; UELL DRILLING;GEOTHERMAL WELLS; OPERATION ; LI CENS I NG

355 INTERRELATIONSHIP BETWEEN FEDERAL, STATE AND LOCAL REGULATORY AGENCIES. Cahrman, T.H. (Univ. Calif., Riverside). Pp 220-34 of Geothermal world directory 1973. Meadows, K.F. (ed.). Glendora, CA; Katherlne F. Meadows (Aug 1973).

For exploration and exploltation of US geothermal resources. GEOTHERMAL RESOURCES: GEOTHERMAL ENERGY; LEGAL ASPECTS;REGULATIONS; USA ; GEOTHERMAL EXPLORAT ION; GEOTHERMAL WELLS: OPERATION; LAND LEAS ING; GEOTHERMAL POWER PLANTS; LICENSING; COOPERATION; REGULATORY AGENCIES; STATE GOVERNMENT; LOCAL GOVERNMENT;US ORGANIZATIONS

356 TOWARD A NATIONAL ENERGY POLICY. Frledlander, G.D. IEEE Spectrum; 10: No. 6, 36-43( Jun 1973).

Agencies adminlstering energy and attendant policy problens. ENERGY POLICY iLEGAL ASPECTS; USA ; REGULATI ONS ; ENUIRONMENT ; ECONOMICS ; COAL; PETROLEUM:ENERGY SOURCES;GEOTHERMAL ENERGY: SOLAR ENERGY; NUCLEAR POWER

357 ENVIRONMENTALLY SENSITIVE LAND USE REGULATION IN CALIFORNIA. HInters, J.H. San Diego Law Rev.: 10: No. 4, 693-756(Jun 1973). The thesis of this article is that by arguing analogously from the National Environmental Pollicy Act to Callfornia Envi ronmental quality Act to obtain adequate disclosure of adverse envil ronmental effects from proposed land uses, and by using the facts thus disclosed in making the requisite findings for The Coastal Zone Initiative (popularly known and Proposition 20) and other laus regulating new subdivisions, decision makers may be requiled to deny permits in certain environmentally sensitive areas that are currently under great development pressures. This paper also analyzes several callfornia and non-California court cases to approach the issue of whether this denial constitutes an unconstitutional use of the police power. fully comprehend the possible far-reaching effects of these statutes and cases an understanding of environmentaliy sensitive land use regulation, the particlpants in the systems, and the role of the courts in the local decision making is essential. (PCS)

358 PUBLIC POLICY TOWARD ENVIRONMENT 1973: A REVIEU AND APPRAISAL. NUCLEAR AND OTHER ENERGY. Seaborg, G.T. (Unive of Callfornia, Berkeley); Bloom, J.L.: Nelson, E.L. Ann. N.Y. ACad. Scl.: 216: 79-88(18 May 1973). NUCLEAR POWER; ENVIRONMENT; SAFETY; GEOTHERMAL ENERGY;SOLAR ENERGY; WIND POWER;TIDAL POWER; ECONOMICS;ENERGY SOURCES ; PLANNING; LEGAL ASPECTS: REGULATIONS;SITE SELECTION; POLLUTION; GOVERNAENT POLICIES

359 S.1283, NATIONAL ENERGY RESEARCH AND DEVELOPKENT POLICY ACT OF 1973. Jackson, H.M. Uashington, DC; US Senate, Committee on Interior and Insular Afrairs (Mar 1973). 59p. From Proceedings and Debates of the 93rd 
Congress, First Session: Washington, DC (Monday, 19 Mar 1973). USA :ENERGY POLICY :RESEARCH PROGRAMS: LEGISLAT ION; SHALE OIL; COAL GASIFICATION: GEOTHERMAL ENERGY; COAL LIQUEFACTION; ENERGY SOURCES; US ERDA

360 (NP--20212) UnCl FINAL ENVIRONMENTAL STATEMENT FOR THE GEOTHERMAL LEASING PROGRAM. VOLUME I. PROMULGATIDN OF LEASING AND OPERATING REGULATIONS. (Department of the Interlor, Washington, D.C. (USA)). 1973. 520p. GPO \$4.20.

GEOTHERMAL RESOURCES: LAND LEASING: ENUIRONMENTAL EFFECTS; REGULATIONS; USA; GEOTHERMAL ENERGY: ENVIRONHENTAL IMPACT STATEHENTS

361 (PB--230248) UnCl TOHARD A NATIONAL POLICY ON ENERGY RESOURCES AND MINERAL PLANT FOODS. (SPECIAL PUBLICATION). Ell I son, S.P., Jr. (Texas Univ., Austin. Bureau of Economic Geology). 1973. 138p. NTIS \$4.75; \$1.45 (ar).

ENERGY POLICY;ECONOMICS ; ENERGY SOURCES;COAL; PETROLEUM:COAL GASIF ICATION; NUCLEAR ENERGY; NATURAL GAS; ENERGY SUPPLIES; MINERALS ; SOLAR ENERGY ; FORECASTING ; ENERGY CONSERVATION; POLLUT ION; ENVIRONMENTAL EFFECTS; GEOTHERMAL ENERGY ; PLANTS;FERT ILIZERS ; GEOLOGY;EDUCATION

362 ENERGY AND THE FUTURE. Hammond, A.L.: Hetz, W.D.; Maugh, T.H. II. WashIngton, DC: American Association for the Advancenent of Sclence (1973). 196p. \$3.95.

BOOK. WASTES; FUEL CELLS;ENERGY SOURCES; FOSSIL FUELS ;LEGAL ASPECTS ;ENVIRONMENT : NUCLEAR ENERGY : SOLAR ENERGY; GEOTHERMAL ENERGY; THERMONUCLEAR REACTIONS; ENERGY TRANSPORT ;ENERGY CONSERVATION:ECONOHICS; USA

\section{AMERICA'S ENERGY POTENTIAL: A SUMMARY} AND EXPLANATION PREPARED BY CONGRESSMAN MORRIS K. UDALL, CHAIRMAN, SUBCOMMITTEE ON THE ENVIRONMENT FOR USE OF THE COMMITTEE ON INTERIOR AND INSULAR AFFAIRS OF THE U.S. HOUSE OF REPRESENTATIVES, NINETY-THIRD CONGRESS, FIRST SESSION, DCTOBER 1973. Washington, DC; Joint Committee on Atomic Energy (1973). 22p. GPO.

MEETINGS; USA; ENERGY ; ENERGY SOURCES : PRODUCTION;FOSSIL. FUELS : NUCLEAR FUELS SOLAR ENERGY;GEOTHERMAL ENERGY;WIND;TIDAL POUER; HEAR INGS

364 PRESIDENTIAL ENERGY STATEMENTS. PRINTED AT THE REQUEST OF HENRY M. JACKSON, CHAIRMAN, COMMITTEE ON INTERIOR AND INSULAR AFFAIRS, UNITED STATES SENATE, NINETY-THIRD CONGRESS, FIRST SESSION, PURSUANT TO S. RES. 45, A NATIONAL FUELS AND ENERGY POLICY STUDY. Weshington, DC; Committee on Interior and Insular Affairs (1973). 112p. GPO \$1.05. TRADE: USA ;ENERGY; ENERGY POLICY; FUELS; ENERGY CONSERVATION;ENVIRONMENT ; COAL GASIFICATION ; CDAL LI QUEFACTION ; POWER TRANSHISSION: THERMONUCLEAR REACT IONS: NUCLEAR POWER; SOLAR ENERGY:SHALE OIL: OIL SHALES; GEOTHERMAL ENERGY;NATURAL GAS

365 FINAL ENUIRONMENTAL STATEMENT FOR THE GEOTHERMAL LEASING PROGRAM. VOLUME I. Washington; US Dept. Interior (1973). $421 \mathrm{p}$. GPO \$4.20.

GEOTHERMAL RESOURCES;REGULATIONS: ENVIRONMENTAL EFFECTS: LAND LEASING: MINERALS: MANAGEMENT ; WATER RESOURCES ; ECOSYSTEMS; USA: ENUIRONMENTAL IMPACT STATEKENTS
366 FINAL ENVIRONMENTAL STATEMENT FOR THE GEOTHERMAL LEASING PROGRAM. VOLUME II. Washington: US Dept. Interior (1973). 513p. GPO \$5.85.

GEOTHERMAL RESOURCES; ENUIRONMENTAL EFFECTS: LAND LEASING; CALIFORNIA; GEYSERS GEOTHERMAL FIELD;IMPERIAL VALLEY; GASEOUS WASTES; MINERALS; GROUND SUBSIDENCE; GEOTHERMAL POWER PLANTS: WATER RESOURCES;ENVIRONMENTAL IMPACT STATEMENTS

367 FINAL ENUIRONMENTAL STATEMENT FOR THE GEOTHERMAL LEASING PROGRAM. VOLUME III. Washington: US Dept. Interior (1973). 686p. GPO $\$ 5.60$.

REGULATIONS ; LAND LEASING; GEOTHERMAL RESDURCES ; VAPOR-DOMINATED SYSTEMS ; OPERATION ENUIRONMENTAL EFFECTS;ENVIRONMENTAL IMPACT STATEMENTS

368 FINAL ENVIRONMENTAL STATEMENT FOR THE GEOTHERMAL LEASING PROGRAM, VOLUME IV. Washington: US Dept. Interior (1973). 720p. GPO \$5.65.

LAND LEASING; REGULATIONS: DPERAT ION: ENUIRONMENTAL EFFECTS ; GEOTHERMAL RESOURCES: HEARINGS; ENVIRONMENTAL IMPACT STATEMENTS

369 ROLE OF STATE GOVERNMENT IN THE DEVELOPMENT OF A GEOTHERMAL RESOURCE. Everitts, D.J. Callfornia State Lands Div., Los Angeles). AIChE Symp. Ser.; 69: No. 129, 453-8(1973).

CALIFORNIA ; GEOTHERMAL RESOURCES ; REGULATIONS : WATER RESOURCES; MINERALS ; INORGANIC COMPOUNDS : STATE GDVERNMENT: ENERGY SOURCE DEVELOPMENTS

370 ENERGY IN SOCIETY. Kristorerson, L. (Royal Inst. of Tech., Stockholn). Amblo: 2: No. $6,178-185(1973)$.

Horldwide policy distribution and development. ENERGY:TIDAL POHER; GEOTHERMAL ENERGY;GEOLOGY;FOSSIL FUELS; SOLAR RADIATION: ENERGY POLICY;SOCIOLOGY; ECONOMICS; LEGAL ASPECTS ENERGY SOURCES ;DISTRIBUTION: ENERGY CONSUMPTION; ENERGY SHORTAGES : DEVELOPING COUNTRIES; INDUSTRY; URANIUN ORES;PETROLEUM: COAL; GLOBAL ASPECTS

371 GEOTHERMAL ENERGY. HEARINGS BEFORE THE NINETY-SECOND CONGRESS, FIRST SESSION, U. S. HOUSE OF REPRESENTATIVES, COMMITTEE DN SCIENCE AND ASTRONAUTICS, SUBCOMAITTEE ON ENERGY. Washington, DC; Committee on Sclence and Astronautics (1973). 382p. GPO. GEOTHERMAL ENERGY; GEOTHERMAL POWER PLANTS: RESEARCH PROGRAMS;GOVERNMENT POLICIES: GEOTHERMAL RESOURCES; HEARINGS ; ENERGY POLICY

372 UNITED STATES OF AMERICA VS. UNION OIL COMPANY OF CALIFORNIA. U.S. DISTRICT COURT, N.D. CALIFORNIA CIV. NO. $72-1866 \mathrm{GBH}$. MEMORANDUM OF DECISION. Washington, DC: Geothermal Resources Counc11 (1973). $18 \mathrm{p}$. Dwnership rights of geothermal resources in Sonoma County, California. LEGAL ASPECTS: GEOTHERMAL RESOURCES ; INDUSTRY ; USA; CAL IFORN IA: OWNERSHIP RIGHTS;TAXES;US DISTRICT COURT;LEGAL DEFINITIONS

373 PRESIDENT'S MESSAGE DN ENERGY, 1973. Nixon, R. H. Hashington, DC; Executive Office of the President (1973). vp. ENERGY POLICY; GOUERNMENT POLICIES; ENERGY CONSUMPT I ON ; PRODUCT I ON; FUELS ; PETROLEUM: GEOTHERMAL ENERGY ; LEASES ; PIPELINES ; COAL;NUCLEAR ENERGY;EXPLORATION; TRADE:EFFICIENCY:AIR POLLUTION; CHARGES ; REGULATIONS; CONT INENTAL SHELF; 
LEGISLATION; DEEP WATER OIL TERHINALS;OIL SHALES; ENERGY CONSERVATION; URANIUM;ENERGY SOURCES : MANAGEMENT

374 GEOTHERMAL POWER. WoOd, B. PP 109-121 of Geothermal energy. Armstead, H.C.H. (ed.). Paris; United Nations Educatlonal, Scientific, and Cultural Organization (1973).

GEOTHERMAL ENERGY;ELECTRIC POWER; POWER; POWER TRANSM ISSION ; STEAM ; HATER ; PRODUCT ION ; TURBINES ; DESI GN ; REGULAT IONS ; ENERGY SOURCES; GEOTHERMAL POWER PLANTS

375 GEOTHERMAL RESOURCES RESEARCH. Denton, J.C. (Natlonal Science Foundation, Washington, DC); Dunlop, D.D. pp 335-346 of Geothermal energy. Kruger, P. (ed.). Stanford, CA: Stanford Univ. Press (1973). Needed basic and applied areaso GEOTHERMAL RESOURCES ; ECONOMICS ; LEGAL ASPECTS; USA ; ENERGY SOURCES; ENVIRONMENT ; SAFETY;REGULATIONS : FRACTURES; RESEARCH PROGRAMS

376 GEOTHERMAL WORLD DIRECTORY. MEadows, K.F. (comp.). Glendora, CA; Geothermal World Directory (1973). 242p. \$15.00.

1973. GEOTHERMAL ENERGY;EXPLORATION ; LEGAL ASPECT S; ENER GY CONSUMPTION ; GEOLOGY ; GEOGRAPHY; MANUALS; EDUCATION; POLLUTION LAWS ; MINING LAWS; REVIEWS; COMP ARAT IVE EVALUATI ONS; GEOTHERMAL RESOURCES; GEOTHERMAL FIELDS

377 : INTRODUCTION: THE ENERGY OUTLOOK. otte, C.: Kruger, P. (Union oil Co. of Callfornia, Los Angeles). pp 1-13 of Geothermal energy. Kruger, P. (ed.). Stanford, CA: Stanford Univ. Press (1973). USA . ENERGY SOURCES FOSSIL FUELS: HYDROELECTRIC POWER; NUCLEAR POWER; THERMONUCLEAR REACT IONS; GEOTHERMAL RESOURCES;ECONOMICS ;USA; PROCEEDINGS; AVAILABILITY;SOLAR ENERGY: ENVIRONMENT; LEGAL ASPECTS;GEOTHERMAL ENERGY; ENERGY CONSUMPTION;ENERGY BALANCE;ENERGY DEMAND

376 POTENT IAL FOR ENERGY PRODUCTION FROM GEOTHERMAL RESOURCES. REPORT OF THE SUBCOMMITTEE DN WATER AND POWER RESOURCES, COMMITTEE ON INTERIOR AND INSULAR AFFAIRS, NINETY-THIRD CONGRESS, FIRST SESSION, DECEMBER 1973. Washington, DC; Jolnt Economic Committee (1973). 47p. GPO $\$ 0.50$.

LEGAL ASPECTS;GEOTHERMAL ENERGY;GEOTHERMAL RESOURCES ; RECOMMENDATIONS ; VA POR-DOMI NATED SYSTEMS; POWER POTENTIAL; HOT-WATER SYSTEMS; USA; GEOTHERMAL EXPLORATION;GEOPRESSURED SYSTEMS; HOTDRY-ROCK SYSTEMS;BRINES; ENVIRONMENTAL EFFECTS: FORECA STING; HEARINGS

379 GEOTHERMAL ENERGY. HEARINGS BEFORE THE SUBCOMMI TTEE ON ENERGY OF THE COMMITTEE ON SCIENCE AND ASTRONAUTICS, UNITED STATES HDUSE OF REPRESENTATIVES, NINETY-THIRD CONGRESS, FIRST SESSION ON H.R. 8628, H.R. 9658, SEPTEMBER 11; 13, AND 18, 1973. Washington, DC; Committee on Science and Astronautics (1973). 386p. GPO.

GEOTHERMAL ENERGY ; LEGAL ASPECTS ; MEETINGS ECONOMICS; GEOTHERMAL EXPLORATION;ENERGY SOURCES; HEATING; ENERGY POLICY; RESERVES; HEARINGS;USA

\section{ENVIRONMENTAL ASPECTS OF NUCLEAR}

STIMULATION. Sandquil st, G.M. (Univ. of Utah, Salt lake City); than, G.A. Pp 293-313 of Geothermal energy. Kruger, P. (ed.). Stanford, CAi Stanford Unlv. Press (1973). ELECTRIC POWER;ENVIRONMENT; USA; GEOTHERMAL ENERGY;GEOTHERMAL SYSTEMS;ENVIRONMENTAL EFFECTS;
EXPLOSIVE STIMULATION: NUCLEAR EXPLOSIONS : UNDERGROUND EXPLOSIONS; LEGAL ASPECTS;FOSSIL FUELS; SAFETY;RADIATION PRDTECTION; OPERATION; ECONOMICS

381 PUBLIC AND GEOLOGY-RELATED LEGISLATION IN CALIFORNIA, 1968-1972. Slosson, J.E.; Hauge, C.J. PP $y$ of Geology, selsmleity, and environmental lapact, p. 23-27. Los Angeles, Callf.: Assoc. Eng. Geol - (1973). CALIFORNIA; LEGISLATION; GEOTHERMAL ENERGY; GEOLOGY;EARTHQUAKES ; MINING

382 GEOTHERMAL RESOURCES. Washington, DC: US Senate (1973). $771 \mathrm{p}$.

Potential for production of electricity and heat in Idaho. HEARINGS; WATER RESOURCES; GEOTHERMAL RESOURCES ; POWER POTENTIAL; HEAT : IDAHO: GEOTHERMAL POWER PLANTS;ENUI RONMENTAL EFFECTS; LAND USE

383 RESEARCH, DEVELOPMENT, AND THE ENERGY CRISIS. HEARINGS HELD NOVEMBER 20, 1973. Washington, DC; Committee on Sclence and Astronautics (1973). $207 p$.

RESEARCH PROGRAMS ; ENERGY POLICY;CALIFORNIA: SOLAR SPACE HEATING;SOLAR AIR CONDITIONING: GEOTHERMAL ENERGY; LEGISLATION; ENERGY SOURCES; ENERGY;HEARI NGS

384 ENERGY AND MATERIALS Klaff, J.L. PP 5.1-5.22 of Final report of the National Commlssion on Materials Pollcy. Washington, DC; National Commission on Materials Polley (1973).

ENERGY POLICY;GOVERNMENT POLICIES; MATERIALS; MARKET;ENVIRONMENTAL EFFECTS;ELECTRIC POUER; POWER GENERATION; OCCUPATIONS : REGULATIONS; DEMAND FACTORS ; PETROLEUM REFI NERIES ; COAL; PETROLEUM; NATURAL GAS; SOLAR ENERGY; MAGNETOHYDRODYNAKICS; GEOTHERMAL ENERGY; METHANE; HYDROGEN; ENERGY CONSERVATION ;ENERGY SOURCES; RESEARCH PROGRAMS; ECONOMIC POLICY; EXPLORATION; PLANNING

385 BRIEFING ON ENERGY POLICY. Zraket, C.A.; Greeley, R.S. MeLean, VA; Mitre Corporation (1973). 69p.

ENERGY POLICY;FUELS;ENERGY SUPPLIES: ECONOMICS;ENVI RONMENTAL EFFECTS; NATURAL GAS; CHARGES; COAL ; PRODUCT ION; PETROLEUM ; TRADE; RESERVES; AIR POLLUT ION; COAL PREPARATION; NATIONAL DEFENSE; TAXES ; OIL SHALES; OIL SANDS: NUCLEAR POWER; FBR TYPE REACTORS; GEOTHERMAL ENERGY;SOLAR ENERGY;THERMONUCLEAR REACTORS: ENERGY SOURCES;PLANNING; REVIEUS

386 AMERICA'S ENERGY POTENTIAL: A SUMMARY AND EXPLANATION PREPARED BY CONGRESSMAN MORRIS K. UDALL, CHAIRMAN, SUBCOMMITTEE ON THE ENVIRONMENT FOR USE OF THE COMMITTEE ON INTERIOR AND INSULAR AFFAIRS OF THE U.S. HOUSE OF REPRESENTATIVES, NINETY-THIRD CONGRESS, FIRST SESSION, OCTOBER 1973. Hashington, DC; Jolnt Committee on Atomlc Energy (1973). 22p. GPO.

The survey reports the confirmation of the existence of two energy crises: the lirst results fron an inablilty to extract known resources at a sufficlent rate, already made evident by the gasoline and heat oll shortages. The longer-term crisis involves the ultimate exhaustion of possil fuel resources and can be expected to occur around the end of the century. The status and outlook and what options are avallable to alleviate the developing crises are examined for oll and gas: coal; nuclear energy; solar energy; Indirect solar applications of photosynthesis, wind 
energy, ocean thermal gradients, and conversion of waste naterials; and geothermal energy.

387 ENERGY RESEARCH AND DEVELOPMENT. NINETYTHIRD CONGRESS, FIRST SESSION, DECEMBER 1 , 1973. Washington, DC; Joint Committee on Atomic Energy (1973). 63p. GPO.

COAL; ECONOMICS; ENERGY POLICY; ENERGY SOURCES : ENVIRONMENT ; GAS IFICATION ; GEOTHERMAL ENERGY; LI QUEF ACTION ; MANAGEMENT ;OIL SHALES; RESEARCH PROGRAMS

388 ENERGY OUTLOOK FOR THE 1980.S. A STUDY PREPARED FOR THE USE OF THE SUBCOMMITTEE ON ECONOMIC PROGRESS OF THE JDINT ECONOMIC COMMITTEE, NINETY-THIRD CONGRESS, FIRST SESSION, BY H. N. PEACH, DECEMBER 17, 1973. Hashington, DC; Jolnt Committee on Atomic Energy (1973). 43p. GPD. COAL; ECONOMICS; ENERGY SOURCES ; EXPLORATION GEOTHERMAL ENERGY; NATURAL GAS;NUCLEAR ENERGY; OIL SHALES ; PETROLEUM; PRODUCT ION; REVIEWS ; USA

389 UNITED STATES OF AMERICA VS UNION OIL COMPANY OF CALIFORNIA. U.S. DISTRICT COURT, N.D. CALIFORNIA CIV. NO. 72-1866 GBH. Fed. Suppl.: 369: 1289-1302(1973).

The United States tiled suit seeking a declaration of 1 ts ownership rights in the geothermal stean and associated goethermal resources belng produced by certain defendants under leases from other defendants. The United States a 1 so sought infunctive rellef and damages. On defense motion to dismiss for fallure to state clein upon which relief could be granted, and on a countermotion of the United States for summary judgment, the District Court, George B. Harris, Senior Judge, held that (1) what passed under a Stock Raising Homestead Act patent was fee title, not just the surface estate with a reservation of the subsurface, and (2) the Act's reservation of "coal and other ainerals'" to the United States did not include a reservation of geothermal steam and associated geothermal resources, since they are not 'Minerals' within the meaning of the reservation of the Act and the patents granted thereunder.

390 UNITED STATES GEOTHERMAL LEGISLATION AND ENVIRONMENTAL IMPACT FOR LEASING. GeothermIcs; 1: No. 4, 146-63(Dec 1972). USA ;LEGISLATION;ENVIRONMENTAL EFFECTS; GEOTHERMAL ENERGY; LAND LEASING

391 GEOTHERMAL STEAK ACT OF 1970. PUBLIC LAW 91-581, SENATE RES. 368, 91ST CONGRESS, DECEMBER 24, 1970. Geothermics; 4: 147154(Dec 1972).

Text of the Geothermal stean Act of 1970 is presented which authorizes the secretary of the Interior to make disposition of geothermal stean and associated geothermal resources, and for other purposes. (PCS)

392 ENVIRONMENTAL IMPACT STATEMENT FOR THE GEOTHERMAL LEASING PROGRAM. Barbier, E.; MeKenzle, W.F. (eds.). Geothermics; 4: '155163(Dec 1972).

Iapacts on the environment are generally local in character since the heat must be utllized in close proximity to the point of production. Hater, al $r$, land, and nolse effects are expected to be controllable within any reasonable standard which is now, or may be in the future, established by State and Federal agencies. Inpacts on aesthetics, and other similar environmental effects which may be

caused by industrial development incident to geothermal resource development, would be subject to control pursuant to regulatory provistons and Federel supervision designed to prevent unsightly developnent. (PCS)

393 ASSESSMENT OF GEOTHERMAL ENERGY RESOURCES. Peck, D.L. Washington, DC; US Dept. Interior, Panel on Geothermal Energy Resources (Federal Council for Science and Technology, Comnittee on Energy Research and Development Goals, Executive office of the President, Office of Science and Technology) (Sep 1972). B3p.

USA; GEOTHERMAL RESOURCES;ECONOMICS;

ENUIRONMENTAL EFFECTS; LEGAL ASPECTS; GEOTHERMAL EXPLORATION J.C. (National Sclence Foundation

Denton, Uashington, DC). Trans. Am. Nucl. Soc.; 15: No. 1, 13-14( Jun 1972).

GEOTHERMAL RESOURCES; GEOTHERMAL EXPLORATION GEOTHERMAL ENERGY;GEOTHERMAL POWER PLANTS; POWER GENERATION; RESEARCH PROGRAMS; ENVIRONMENT; POLLUTION:GROUND SUBSIDENCE; LEGAL ASPECTS; ECONOMICS

395 H.R. 14801, TO PROMOTE THE EXPLORATION AND DEVELOPMENT OF GEOTHERMAL RESOURCES THROUGH COOPERATION BETWEEN THE FEDERAL GOVERNMENT AND PRIVATE ENTERPRISE; TEXT. Washington, DC; US Congress, House (4 May 1972). vp. GEOTHERMAL ENERGY; GEOTHERMAL EXPLORATION; EXPLOI TAT ION ; LEGISLAT I ON ; USA ; GEOTHERMAL RESOURCES

396 (PB--208954) UnCl GEOTHERMAL LEASING PROGRAM. (Department of the Interior, Washington, D.C. (USA)). 3 May 1972. 193p. NTIS $\$ 3.00$.

GEOTHERMAL RESOURCES; LAND LEASING;

ENVIRONMENTAL IMPACT STATEMENTS;GOVERNMENT

POLICIES;REGULATIONS; ENERGY SOURCES

397 (PB--208954) UnCl GEOTHERMAL LEASING PROGRAM. (SUPPLEMENT TO DRAFT DATED 6 OCT 1971, PB--203102-D). (Department of the Interior, Washington, D.C. (USA)). 3 May 1972. 193p. NTIS $\$ 3.00$; $\$ 0.95$ (me). LAND LEASING; GEOTHERMAL EXPLORATIDN: ENVIRONMENTAL IMPACT STATEMENTS; ENERGY SOURCES : GOVERNMENT POLICIES; GEOTHERMAL RESOURCES

398 LEGAL AND POLICY ASPECTS OF GEOTHERMAL RESOURCE DEVELOPMENT A Allen, D.R. (Duncan, Allen and Mitchell, Washington, DC). Water Resources Bulletin, Paper 72022; 6: No. 2, 250256(APr 1972 ).

GEDTHERMAL RESOURCES;GEOTHERMAL ENERGY; HATER RESOURCES ; USES ; LEGAL ASPECTS ; PLANNING; POWER GENERATION;ENERGY POLICY;GOVERNMENT POLICIES
399 - GEOTHERMAL RESEARCH. PP 577-85 of Inventory of energy research (by Dak Ridge National Laboratory). Washington, DC; US Congress. House. Committee on Science and Astronautics. Subcommittee on Science, Research, and Development. Task Force on Energy (Har 1972). GEOTHERMAL ENERGY :USA;RESEARCH PROGRAMS: LEGISLATION

400 (PB-218830, PP 23) GEOTHERMAL ACTIVITY IN 1971. Bowen, R.G. 1972 . Exploration and exploitation of geotheraal 
resources in arid and semiarid lands.

GEYSERS GEOTHERMAL FIELD: GEOTHERMAL POWER PLANTS ; POUER GENERATION; PERFORMANCE TESTING; GEOTHERMAL ENERGY; EXPLOITATION;GOVERNMENT POLICIES ; REGULAT IONS ; IMPERIAL VALLEY ; $S A L T O N$ SEA GEDTHERMAL RESOURCES;POHER POTENTIAL;CALIFORNIA

401 GEOTHERMAL WORLD DIRECTORY. Headows, K.F. (ed.). Glendora, CA; Katherine F. Headow (1972). 190p. ENU IRONMENT : GEOTHERMAL ENERGY :ECONOMICS: REGULATIONS;SITE SELECTIDN; SAFETY; GEOTHERMAL RESOURCES

402 GEOTHERMAL ENERGY RESOURCES AND RESEARCH. HEARINGS PURSUANT TO S. RES. 45, A NATIONAL FUELS AND ENERGY POLICY STUDY, ON THE ROLE OF GEOTHERMAL ENERGY RESOURCES IN DUR NATION'S FUTURE ENERGY ECONOMY, JUNE 15 AND $22,1972$. Washington, DC: Committee on Interfor and Insular Affairs (1972). 465p. GPO \$2.75. GEOTHERMAL RESOURCES ; HEARINGS ; GOVERNMENT POLICIES; USA;PQWER GENERATION;ENERGY POLICY

403 ENERGY RESEARCH POLICY ALTERNATIVES. HEARING PURSUANT TO 5 . RES. 45, A NATI ONAL FUELS AND ENERGY POLICY STUDY, ON EXISTING FEDERAL ENERGY RESEARCH AND DEVELOPHENT POLICIES AND FUTURE TECHNOLOGICAL OPTIONS, $U$. 5. SENATE, JUNE 7, 1972. Hashington, DC: Committee on Interior and Insular Afairs (1972). 814p. GPO \$5.25.

ENERGY POLICY;ENUIRONMENTAL EFFECTS;RESEARCH PROGRAMS ; GUVERNMENT POLICIES ; THERMONUCLEAR REACTORS ; COAL GASIFI CATION; GEOTHERMAL ENERGY; NUCLEAR ENERGY; SOLAR ENERGY; ENVIRONMENTAL EFFECTS; HEAR INGS;ENERGY

404 SUMMARY REPORT OF THE CORNELL WORKSHOP ON ENERGY AND THE ENVIRONMENT • HEARING PURSUANT TO S. RES. 45, A NATIONAL FUELS AND ENERGY POLICY STUDY, U. S. SENATE, FEBRUARY 22--24, 1972. Uashington, DC; Committee on Interlor and Insular Affalrs (1972). UP. GPO. ENERGY POLICY;ENVIRONMENT ; ENUIRONMENTAL EFFECTS: GOVERNMENT POLICIES ; HEALTH HAZARDS : NUCLEAR ENERGY;ELECTRIC POUER;DEMAND FACTORS; TRANSPORTATION SYSTEMS ;REGULATIONS ; GEOTHERHAL ENERGY;FOSSIL FUELS;ENERGY SOURCES;COKBUSTIDN; HEAR INGS

405 LONGER-RANGE TECHNOLOGICAL POTENTIALS FOR ENERGY DEVELOPHENT: AN ASSESSMENT OF THE PROSPECTS IN NEW ENERGY TECHNOLOGY. Starr, C. (Univ. of Callfornla, Los Angeles): Law, S.H.: Gregory, D.P.: Cochran, N.P.: Mayfield, L.G.: Balzhlser, R.E.: Gottlieb, M.B. PP 143-174 of Energy and public pollcy. Murphy, J.J. (ed.). New York; Conference Board (1972).

ENERGY; ENERGY STORAGE; FOSSIL FUELS;ENERGY SOURCES; PLANNING ; NUCLEAR ENERGY; GEOTHERMAL ENERGY : HEETINGS ; ENERGY CONVERSION; ENERGY STORAGE; ENUIRONMENTAL EFFECTS;BUDGETS;RESEARCH PROGRAKS ; NATIONAL SCIENCE FOUNDATION;

FORECAST ING; THERMONUCLEAR REACTORS

406 ADMINISTRATION'S ENERGY MESSAGE AND PROGRAK: THE NEED FOR PROMPT DEVELOPMENT DF A NATIONAL ENERGY POLICY. Pecora, W.T. (Dept. of Interior. Washington, DC). Pp 23-29 of Energy and public policy. Murphy, J.J. (ed.). New York: Conference Board ( 1972 ).

ENERGY POLICY;USA ;ENERGY SOURCES; PLANNING; PRODUCTION;COAL GASIFICATION ; GEOTHERMAL ENERGY: OIL SHALES ; CHARGES :ENUIRONMENTAL EFFECTS
HEARINGS BEFORE THE COMMITTEE ON INTERIOR AND INSULAR AFFAIRS, UNITED STATES SENATE, PURSUANT TO S. RES. 45; A NATIONAL FUELS AND ENERGY POLICY STUDY, NINETY-SECOND CONGRESS, SECOND SESSION ON THE ROLE OF GEOTHERMAL ENERGY RESOURCES IN OUR NATION'S FUTURE ENERGY ECONOMY, JUNE 15 AND 22, 1972. Washigton, DC; Committee on Interior and Insular Affalrs (1972). 480p. GPO\$2.75.

GEOTHERMAL ENERGY;LEGAL ASPECTS ; GEOTHERMAL RESOURCES; LAND LEASING;ENUIRONHENTAL EFFECTS : FORECASTING; HEARINGS ; USA ; ENERGY POLICY

408 GEOTHERMAL RESOURCES IN CALIFORNIA. Anderson, D.N.; Axtell, L.H. (Callfornia State DIV. of $0 I 1$ and Gas, Sacramento). pP $v$ of Geothermal overulews of the vestern United States, 1972. Proceedings of Geotheraal Resources Council El Centro Conference. Paper B. Davis, CA; Geothermal Resources Council (1972).

From Geothernal Resources Counc11 El Centro Conference: Davis, CA (16-18 Feb 1972). 32,000 MH power cepeclty (1970). CALIFORNIA GEOTHERMAL RESOURCES ; GEYSERS GEOTHERMAL FIELD; GEOTHERMAL POWER PLANTS; PLANNING; GEOTHERMAL ENERGY;ELECTRIC POWER: POWER GENERATION;HOT SPRINGS ; GEYSERS; THERMAL UATERS ; LEGISLATION; POHER PQTENTIAL

409 GEOTHERMAL EXPLORATION AND DEVELOPMENT IN NEVADA. Garside, L.J.; Schllling, J.H. (Nevada Bureau of Mines and Geology, Reno). pp $y$ of Geothermal overviews of the western United States, 1972. Proceedings of Geotheral Resources Councli EI Centro Conference: Paper H. Davis, CA: Geothermal Resources Council (1972).

From Geothernal Resources Counc 11 El Centro Conference: Davis, CA (16-18 Feb 1972).

Water temperature greater than 3500F. NEVADA: GEOTHERMAL RESOURCES ; GEOTHERMAL EXPLORATION; THERMAL HATERS;ELECTRIC POWER; GEOTHERMAL WELLS : HYDROLOGY ; GEOLOGY; GEOPHYSICAL SURVEYS; DRILLING; LAND LEAS ING

410 GEOTHERMAL RESOURCES, PRESENT AND FUTURE DEMAND FOR POWER, AND LEGISLATION IN THE STATE DF WYOMING. Decker, E.R. (Hyoming UnIV., Laranle. Dept. of Geology). pp $v$ of Geothermal overviews of the western United States, 1972. Proceedings of Geothermal Resources Council El Centro Conterence, Feb 1618, 1972, Davis, Callfornia. Paper M. Davis, CA: Geothermal Resources Councli (1972): From Geothermal Resources Council El Centro Conference: Davis, CA (16-18 Feb 1972). WYOMING; GEOTHERMAL RESOURCES;THERMAL WATERS : HOT SPRINGS ; CHEMICAL COMPOSI IION ; LEGISLATION: GEOTHERMAL ENERGY : GEOTHERHAL EXPLORATION : ELECTRIC POWER ECONOMICS ; GEOLOGY ; POWER DEHAND

411 : PQWER FROM THE EARTH: GEOTHERMAL ENERGY Tompkins, D.C. Berkeley: Univi of Callfornia, Inst. of Governmental Studles (1972). 34p. Library of Congress $\$ 2.50$.

GEOTHERMAL ENERGY ; BIBLIDGRAPHIES; RESEARCH PROGRAMS ; USA ; REGULAT IONS ; ENERGY POLICY

412 COMPENDIUM OF FIRST DAY PAPERS PRESENTED AT THE FIRST CONFERENCE OF THE GEOTHERMAL. RESOURCES COUNCIL, EL CENTRO, CALIFORNIA, FEB 1972. Anderson, D.N.: Axtell, L.H. (ed.). Davis, CA; Geothermal Resour. Counc. (1972). 77p.

CALIFORNIA; GEOTHERMAL RESOURCES; EXPLOITATION; ENUIRONMENTAL EFFECTS : MEET INGS ; LEGAL ASPECTS: GEOTHERMAL ENERGY 
413 REVIEW OF SOME OF THE LEGAL PROBLEMS IN GEOTHERMAL DEVELOPMENT. AIdIIn, J.W. PP 6977 of Geothermal Resources Council, Conference, No. 1. Davis, CA; Geothermal Resour. Counc. (1972).

USA :GEOTHERMAL ENERGY;LEGISLATION;LEGAL ASPECTS; LAWS:

414 FEDERAL GOVERNHENT LEASING AND OPERATING REGULATIONS AND ENVIRONMENTAL IMPACT STATEMENTS. Stone, R.T. PP 5-9 of Geothermal Resources Council, Conference, No. 1. Davis, CA; Geothermal Resour. Counc. (1972).

USA:GEOTHERMAL ENERGY;LAND LEASING; LEGISLATION;ENUIRONMENTAL IMPACT STATEMENTS; GEOTHERMAL RESOURCES;PUBLIC LANDS;REGULATTIONS

415 EXOP REPORT ON FEDERAL ENERGY R AND D FUNDING. PP 297-301 of Energy and public pollcy. Washington, DC; Executive office of the President (1972).

ENERGY; SOLAR ENERGY ; BUDGETS;RESEARCH PRDGRAMS ; THERMONUCLEAR REACTORS ; GOVERNMENT POLICIES;NUCLEAR ENERGY; COAL ; PETROLEUM PRODUCTS; NATURAL GAS; BREEDER REACTORS ; COAL GASIFICATION; SULFUR OXIDES;REMOVAL;ENVIRONMENTAL EFFECTS; LMFBR TYPE REACTORS; GEOTHERMAL ENERGY

416 REICH, A.E. ET AL. VS COMMISSIONER OF INTERNAL REVENUE AND G.D. ROWAN ET AL. US COMMISSIONER OF INTERNAL REVENUE. U.S. COURT OF APPEALS, NINTH CIRCUIT. JANUARY 21, 1972. Fed. Rep.: 2: No. 454, 1157-1159(1972). From declisions of the tax court, 52 T.C. 700 , favorable to taxpayers, an appeal was taken. The Court of Appeais, Wright, Circuit Judge, held that taxpayers' reserves or geothermal steam constituted an exhaustible natural resource and that geothermal steam was a 'igasi' within meaning of Internal Revenue Code provisions for percentage depletion deduction for intanglble costs of drilling and developing ofl and gas wells. Aftirmed.

417 SALT HATER IS A MINERAL: OWNERSHIP OF A NATURAL RESOURCE OF INCREASING IMPORTANCE IN DIL-PRODUCING STATES. Hudson, $L$. Tex. Law Rev.: 50: 448-461(1972).

Salt water, resource with newfound promise, defles easy allocation between the surface and alneral estates. The author, relying on history, precedents, and pollcy, contends that salt water should be classifled as a mineral belonging to the mineral owner whereas domestle water should be considered a nonineral appurtenant ta the surface estate.

418 GEOTHERMAL RESOURCES IN CALIFORNIA-POTENTIALS AND PROBLEMS. Goldsmith, $M$. Pasadena, CA; Calle. Inst. Tech., Envi ronmental Quality Lab. (Dec 1971). 45 p. GEOTHERMAL RESOURCES; CALIFORNIA;ECONOMICS; POUER POTENT IAL; GEYSERS GEOTHERMAL FIELD: GEOTHERMAL POWER PLANTS; THERHAL WATERS; VAPORDOMINATED SYSTEMS;ENVIRONMENTAL EFFECTS;GROUND SUBSIDENCE; BLOWOUTS; SEISHIC WAVES;AIR POLLUTION; GASEOUS WASTES

419 GEOTHERMAL ENERGY, ITS FUTURE AND ECONOMICS. Horvath, J.C.: Chaffin, R.L. (Georgla State Unlv., School of Business Administration). Atlanta Econ. Rev.: $21:$ No. 12, 15-33(Dec 1971). GEOTHERMAL ENERGY; GEOTHERMAL RESOURCES; LEGAL ASPECTS; DRILLING;EXPLOSIVE STIHULATION : GEOTHERMAL EXPLORATION; NUCLEAR EXPLOSIVES;
ECONOMICS;USES ; ENVIRONMENTAL EFFECTS :USA; REVIEWS; GEYSERS GEOTHERMAL FIELD; GEOTHERMAL POWER PLANTS

420 EARTH'S HEAT TAPPED FOR GEOTHERMAL POWER DEVELOPMENT. Allen, D.R. (Duncen, Allen, and Mitchell Law Firm). Public Power; 29: No, 6, 35-9( Nov-Dec 1971).

GEOTHERMAL RESOURCES; EXPLOSIVE STIMULATION: COST ; LEGAL ASPECTS;ENVIRONMENTAL EFFECTS: GEOTHERMAL ENERGY; POWER POTENTIAL; REVIEUS; ECONOMICS

421 (PB--203102-D) UnCl GEOTHERMAL LEASING PROGRAK, CONSIDERS IMPACT OF LEASING AND OPERATING REGULATIONS TO IMPLEMENT THE GEOTHERMAL STEAM ACT OF 1970 AND LEASING OF 3 AREAS IN CALIFORNIA. DRAFT ENVIRONMENTAL IMPACT STATEMENT. (Department of the Interior, Washington, D.C. (USA)). 6 Det 1971. 234p. NTIS $\$ 3.00$.

CALIFORNIA; GEOTHERMAL EXPLORATION:LAND LEASING; ENVIRONMENTAL IMPACT STATEMENTS; GEOTHERMAL STEAM ACT ; REGULATIONS ; GEOTHERMAL RESOURCES

422 ENVIRONMENTAL IMPACT STATEMENT FOR THE GEOTHERMAL LEASING PROGRAM; DRAFT. Washington, DC; US Dept.. Interior (Sep 1971). vp.

CALIFORNIA;GEOTHERMAL FIELDS; GEOTHERMAL RESOURCES;EXPLOITATION;ENVIRONMENTAL IMPACT STATEMENTS : LAND LEASING

423 GEOTHERMAL RESOURCES LEASING AND OPERATIONS ON PUBLIC, ACQUIRED, AND WITHDRAWN LANDS. II. Pecora, H.T. Fed. Regist. (Wash., D.C.): 36: No. 142, 13722-13740(23 Jul 1971). (43CFR3000; 43CFR3045; 43CFR3200; 30CFR270).

Text of proposed amendments to existing regulations and procedures to be followed in conducting exploration of the public land for oll and gas or geothermal resources are presented. Regulations are for implementation of the Geothernal Steam Act. Leasing subparts Include definitions; geophysical exploration operations; avallable land, linitation, unit agreements; lessee qualification; leasing terms: surface management requil rements; service charges, rental and royalties; lease bonds; noncompetitive leases; land prevlously leased for geothermal resources; competitive leases; conversion rights to geothermal leases or application for leases; leasing rules; extension, assignments and transfers: production and uses of byproducts; cooperative conservation provisions; terminations and explrations. Operations subperts cover definitlons, supervisor functlons and Jurlsdiction; lessee (including operator) requl renents relative to drilling and well operations for production, pollution control, nolse abatement, safety and abandonment; measurement of production and computation of royalties; and required report. (PCS)

424 S. CON. RES. 29, TO EXPRESS THE SENSE OF CONGRESS THAT THE BUREAU OF RECLAMATION SHOULD ACCELERATE ITS INVESTIGATIONS OF GEOTHERMAL RESOURCES AS A POTENTIAL MAJOR NEW SOURCE OF HATER SUPPLIES FOR THE HESTERN UNITED STATES: TEXT; STATEMENT.- Hashington, DC; US Congress. Senate ( 7 Jun 1971). vp.

USA;WATER RESOURCES; GEOTHERMAL RESDURCES LEGISLATION 
AND CLEAN AIR, ALSO FACT SHEET FROM OFFICE OF THE WHITE HOUSE PRESS SECRETARY. NiXON, R.M. Washington, DC; Executive Office of the President (4 Jun 1971). 12p.

USA;ENERGY POLICY;ENVIRONMENT ;ENERGY SUPPLIES;EARTH ATMOSPHERE; AIR POLLUTION; SULFUR OX IDES ; COAL; RESEARCH PROGRAMS; THERMONUCLEAR REACTORS ; NUCLEAR POWER PLANTS;MHD GENERATORS ;* POWER TRANSMISSION LINES;FOSSIL FUELS; GEOTHERMAL ENERGY;NUCLEAR FUELS; ENERGY CONSERVATION;ELECTRIC POUER; POWER PLANTS; SITE SELECT ION; RESEARCH PROGRAMS; LAND LEASING

426 GEOTHERMAL STEAF ACT OF 1970: KNOWN GEOTHERMAL RESOURCES AREAS; PARTIAL LIST. (US Dept. Interior. Geol. Surv.). Fed. Reglst. (Wash. D.C.); vp(Mar-Apr 1971). USA ; GEOTHERMAL RESOURCES ; LEGI SLATION ; GEOTHERMAL STEAH ACT;KGRA

\section{S. 564, TO ESTABLISH A FIVE-YEAR} GEOTHERMAL RESEARCH PROGRAM; TEXT; STATEMENT. Washington, DC; US Congress. Senate ( 3 Feb 1971). vp.

USA;GEOTHERMAL ENERGY;RESEARCH PROGRAMS; LEGISLATION

428 GEOTHERMAL STEAM ACT OF 1970; PROCEDURE TO BE FOLLOWED IN CLAIMING RIGHTS. Fed. Regist. (Wash., D.C. ); 623(15 Jan 1971). USA; GEOTHERMAL RESOURCES; LEGI SLATION; GEOTHERMAL STEAM ACT

429 (CONF-710571--, pp up, Paper 6) IMPLEMENTING THE FEDERAL GEDTHERMAL STEAM ACT OF 1970. Stone, R.T. 1971 .

From 1. northwest conference on geothermal power; OIympla, Washington, USA ( 21 May 1971). power.

Irst northwest conference on geothermal

LEGISLATION; GEOTHERMAL ENERGY; GEOTHERMAL RESOURCES ; LAND LEASING; US ORGANIZATIONS; ENVIRONMENTAL IMPACT STATEMENTS; GEOTHERMAL STEAM ACT; IMPLEMENTATION

430 (PB--218830, PP 72) ENERGY COMPANY: A MONOPOLY TREND IN THE ENERGY MARKETS. Netschert, B.C. 1971 .

Exploration and exploitation of geothermal resources in arid and semlarid lands.

USA ; ENERGY SUPPLIES; MARKET ; ECONOMICS; INDUSTRY ; COST; ELECTRIC POWER;RECOMMENDATIONS REGULATIONS; GOVERNMENT POLICIES

431 (PD--218830, PP 89) GEOTHERMAL LEASING PROGRAM (DRAFT ENVIRONMENTAL IMPACT STATEMENT). 1971 .

Exploration and exploitation of geothermal resources in arid and semiarld lands.

USA;GEOTHERMAL RESOURCES;LEGAL ASPECTS: ENVIRONMENTAL - IMPACT STATEMENTS; GEOTHERMAL POHER PLANTS; REGULATIONS ; GEOTHERMAL EXPLORATION; LEGISLAT ION; LAND LEASING; POLLUTION ; GROUND SUBSIDEN CE

432 GEOTHERMAL SCIENCE AND TECHNOLOGY: A NATIONAL PROGRAM. Austin, G.F.: Austin, H.H. Jr.: Leonard, G.W. PP 341-461 of Geothermal energy resources and research. China Lake, CA: Department of Defense (1971).

GEOTHERMAL ENERGY;CALIFORNIA; REVIEWS: RESEARCH PROGRAMS ; COST ; POWER GENERATION;HEAT: HEARINGS;GEOTHERMAL RESOURCES;USA; GOVERNMENT POLICIES
COMMITTEE ON INTERIOR AND INSULAR AFFAIRS. Nassikas, J.N. Washington, DC; Federal Power Comission (1971). 80p. GPO.

Four Corners Area. USA;ELECTRIC POWER; POWER GENERATION;FOSSIL-FUEL POWER PLANTS; NUCLEAR POWER PLANTS;GEOTHERMAL ENERGY;SOLAR ENERGY; FUEL CELLS;ENERGY POLICY;HEARINGS; NATURAL GAS ; FUEL OILS;LEGAL ASPECTS

434 CLASSIFICATION OF PUBLIC LANDS VALUABLE FOR GEOTHERMAL STEAM AND ASSOCIATED GEOTHERMAL RESOURCES. Godwin, L.H.; Halgler, L.B.; Rloux, R.L.; White, D.E.: Kuffler, L.J.P. Washington, DC; US Geological Survey (1971). $18 \mathrm{p}$.

Geothe rmal st eam act of 1970. USA; GEOTHERHAL RESOURCES ; LEGAL ASPECTS ; LEGI SLATION;HOT SPRINGS THERMAL WATERS;GROUND WATER;STEAM; GEOTHERMAL STEAM ACT

435 GEOTHERMAL ENERGY PROSPECTS IN RELATION TO POLICY OF REGIONAL UTILIZATION OF ENERGY RESOURCES IN INDONESIA. Hoesn I, A.M.: Arismunandar, A.: Radja, V.T. Trans. World Energy Conf., 8th; 4: (1971). From 8. World Energy Conference: Bucharest, Rom. (28 Jun-2 Jul 1971).

GEOTHERMAL ENERGY; GEOTHERMAL RESOURCES; INDONESI A ; RESERVES ; GOVERNMENI' POLICIES

436 COMMENTS ON DRAFT ENVIRONMENTAL IMPACT STATEMENT FOR THE FEDERAL GEOTHERMAL LEASING PROGRAMS. Finn, D.F.X. New York; Geothermal Energy Institute (1971). 575p. GEOTHERMAL FIELDS;USA;LAND LEASING;

ENVIRONMENTAL IMPACT STATEMENTS

437 NATURAL RESOURCES DEVELOPMENT AND POLICIES, INCLUDING ENUIRONGENTAL

CONSIDERATIONS. New York: United Natlons

(1971). $19 p$.

ENERGY SOURCES;ENUIRONMENTAL EFFECTS; ENUIRONMENT ; ENERGY POLICY; PETROLEUM; AIR POLLUTION; WATER POLLUTION; HATER POLLUTION; EXHAUST GASES; GEOTHERMAL ENERGY; HYDROELECTRIC POWER PLANTS; POWER GENERAT ION; IIDAL POWER; POUER TRANSMISSION;SATELLITES;ELECTRIC POWER; COAL; PETROLEUM INDUSTRY;ORBITAL SOLAR POWER PLANTS; ENERGY CONSUMPTION

438 NATURAL RESOURCES DEVELOPMENT AND POLICIES, INCLUDING ENUIRONMENTAL

CONSIDERATIONS. NOTE BY THE SECRETARY-GENERAL: ADDENDUM, CHANGING PATTERNS IN THE WORLD ENERGY SITUATION. New York; United NatIons (1971). vp.

ENERGY SUPPLIES;ENERGY CONSUMPTION; ENERGY SQURCES ; ENERGY DEMAND; STAT ISTICS ; COAL; PETROLEUM; NATURAL GAS ; GEOTHERMAL ENERGY ; SOLAR ENERGY : NUCLEAR ENERGY;UIND POHER; TIDAL POUER; ENVIRONMENTAL EFFECTS ; REVIEUS; ENERGY POLICY

439 ECONOMICS OF THE COMMON POOL: PROPERTY RIGHTS IN EXHAUSTIBLE RESOURCES. Frledman, A.E: UCLA LaW Rev.; 18: 855-887(1971). A brief overview introduces the problea then focuses on the meaning of soclally optimal rate of exploitation of an exhaustible resource. The problem of externality in the common pool is examined and an economic analysis is developed to explain how differing ownership rights affects the rates at which exhaustible resources are explolted. A general theoretical solution is proposed and illustrated with an application to groundwater aining. (PCS) 
440 GEOTHERMAL STEAM ACT OF 1970. Bible, A. Idaho Law Rev.: 8: 86-92(1971).

Legislative history and intent for passage of the Act are reviewed and compared with the Mineral Leasing Act ( 30 USC 223). Projected litigation over mineral rights' ownership clauses is expected to delay geothermal exploration and development. (PCS)

441 LAW OF OIL AND GAS. Hemingway, R.W. St. Paul: West Publishing Co. (1971). 50Bp. Titles of the nine chapters are: mineral estate; definition; creation of interests in the ofl and gas mineral estate by the landowner: conveyances, partition and adverse possession of the alneral estate; trespass, surface and sub-surface, and third party claims; the oil and gas lease (leases from owners of concurrent, successive, or restricted interests: duration; royalty and other particular lease clauses): covenants of the lessee to protect, develop, and administer the lease: and, transfers by the lessor and the lessee. A table of cases and a subject index are also included. (JGB)

442 FREE ELECTRICITY; PLAN TO GET MORE ENERGY FROM HEAT INSIDE EARTH MDVES FORWARD A BIT (GEOTHERMAL STEAM ACT OF 1970). Large, A.J. Wall St. J.: $1+(10$ Dec 1970).

GEOTHERMAL ENERGY;NATURAL STEAM; POHER GENERATION; ELECTRIC POHER; LEGISLATION; GEOTHERMAL STEAM ACT

443 (PB--196325) UnCl ENERGY FUEL MINERAL RESOURCES OF THE PUBLIC LANDS. VOLUME VI: LEGAL STUDY OF COAL RESOURCES ON PUBLIC LANDS; GEOTHERMAL RESOURCES ON PUBLIC LANDS. INTERIM REPORT. (Utah Univ., Salt Lake City. College of Law ). Dec 1970. Contract PLLRC--68-C-11. $630 \mathrm{p}$. NTIS $\$ 9.00$; $\$ 0.95$ (mf).

COAL RESERVES ; GEOTHERMAL RESOURCES; LEGAL ASPECT S; MINERAL SPRINGS; LAND LEASING; PUBLIC LANDS; MI NERAL RESOURCES

444 AUTHORIZING THE SECRETARY OF THE INTERIOR TO MAKE DISPOSITION OF GEOTHERMAL STEAM AND ASSOCIATED GEOTHERMAL RESOURCES REPORT TO ACCDMPANY S. 368. Washington, DC; US Congress. House, Committee on Interlor and Insular Affairs ( 30 Sep 1970). $22 p$. USA;GEOTHERMAL RESOURCES; LEGISLATION; NATURAL STEAM; GEOTHERMAL ENERGY

445 GEOTHERMAL RESOURCE DEVELOPMENT; REPORT TO ACCOMPANY S. 368. Hashington, DC; US Congress. Senate. Committee on Interior and Insular Affairs (4 Sep 1970). 30 . USA ; GEOTHERMAL RESOURCES; LEGISLATION; EXPLOITATION

446 GEOTHERMAL STEAM AND RESOURCES. Hashington, DC; US Senate, Committee on Interior and Insular Affalrs (Jul 1970). NATURAL STEAM; GEOTHERMAL RESOURCES; LEGAL ASPECTS; POWER GENERATION ; ENVIRONMENTAL IMPACT STATEMENTS; HEARINGS

447 (PD--218830, PP 88) GEOTHERMAL STEAM ACT OF 1970 (EXPLOITATION AND DEVELOPMENT OF GEOTHERMAL STEAK RESOURCES). 1970.

Exploration and exploitation of geothermal resources in arid and semiarid lands. USA; GEOTHERMAL. RESOURCES; REGULATIONS; GOVERNMENT POLICIES; EXPLOITATION;LEGAL ASPECTS; LEGISLATION; LAND LEASING; GEOTHERMA STEAM ACT
448 GEOTHERMAL STEAM ACT OF 1970.

EXPLOITATION AND DEVELOPMENT OF GEOTHERMAL STEAM RESOURCES. Washington, DC; US Congress (1970). 11p.

GEOTHERMAL RESOURCES ; LEGISLAT ION ; NATURAL STEAK; THERMAL WATERS;EXPLOITATION;BRINES;LAND LEASING; GEOTHERMAL EXPLORATION;GEOTHERMAL STEAH ACT

449 ECONOMICS OF GEOTHERMAL POWER IN THE UNITED STATES. Kaufman, A. (Director, offlce of Economic Research, Public Serv. Com., Albany, NY). Geothermics: No. 2, 967p-(1970). GEOTHERMAL ENERGY;ECONOHI CS ;USA ; GEYSERS : CALIFORNIA;FORECASTING;ELECTRIC POWER; LEGAL ASPECTS;ENUI RONMENTAL EFFECTS; POLLUTION

450 COMPENDIUM OF PAPERS PRESENTED AT THE IMPERIAL VALLEY--SALTON SEA AREA GEOTHERMAI HEARING, OCT 22 AND 23. Sacramento: Callfornia Geothermal Research Board, State of Callfornia Jolnt Legislative Committee on Atomle Development (1970). vp.

IMPERIAL VALLEY; SALTON SEA; CALIFORN IA; HEARINGS ; GEOTHERMAL ENERGY ; GEOTHERMAL RESOURCES

451 ELECTRIC POWER, FUELS DEVELOPMENT, AND PROTECTION OF THE ENUIRONMENT: LEGISLATION INTRODUCED IN THE 91ST CONGRESS. Bowman, H.D. Washington, DC; Library of Congress (1970). 25p.

ENERGY POLICY;ELECTRIC POWER; POWER GENERATI ON; ENVIRONMENT ; LEGISLATION ; NUCLEAR POWER PLANTS;REGULATIONS;OIL SHALES; WATER POLLUTION ; SURFACE MINING ; MINERALS; GEOTHERMAL ENERGY;DEMAND FACTORS; GOVERNMENT POLICIES; NATURAL GAS;AIR POLLUTION; POHER TRANSMISSION; WASTE HEAT; ENERGY SOURCES

452 ONE THIRD OF THE NATION'S LAND: A REPORT TO THE PRESIDENT AND TO THE CONGRESS BY THE PUBLIC LAND LAW REVIEW COMMISSION. Washington, DC; Public Land Law Revlew Commission (1970). 355p. GPO.

The Public Land Law Review Commission was charged with reviewing laws, policles, practices, and procedures affecting the public lands in the U.S. Which constitute about onethird of its land area. The full test of the statute creating the Commission is given in Appendix A. Chapter I describes what and where public lands are and Chapter II discusses to whom public lands are important. One hundred and thirty-seven specific

recommendat lons are discussed in the following chapters entitled: Planning Future Public Land Use; Public Land Policy and the Environment; Timber Resources; Range Resources; Mineral Resources; Water Resources; Fish and Wildlife Resources; Intensive Agriculture; the Outer Continental Shelf; Outdoor Recreation:

Occupancy Uses; Tax Immunity: Land Grants to States: Administrative Procedures; Trespass and Disputed Title; Disposals, Acquisitions, and Exchanges; Federal Leglslation Jurisdiction: and Organization, Administration, and Budgeting Pollcy. Personnel data and functlons of the agencies are discussed in other appendices. (MCW)

453 ENERGY FUEL MINERAL RESOURCES OF THE PUBLIC LANDS. VOLUME I. MASTER REPORT: A STUDY PREPARED FOR THE PUBLIC LAND LAW REUIEW COMMISSION. Cambridge, MA; Abt Assoclates (1970). 434p. (PB--196320). NTIS

The report constitutes the resources portion of study of energy fuel mineral resources of the public lands. General considerations 
Include: to what extent, if any, should fuel al neral exploration, development, and production on the public lands be 1 imited by declaring el ther that some public lands shall not be avilable for this purpose, or that special restrictions should be made applicable to some classes of public lands. In what circumstances, if any, should the fuel mineral Interest be reserved to the United $s$ tates when disposing of public lands for other uses. Should public lands containing fuel minerals be disposed of and, if so, under what conditions. What pollcy or polfcles should govern the pricing of energy fuel minerals on public lands.

454 GEOTHERMAL STEAM POSES OWNERSHIP QUESTIONS. Electr. Horld: 171: 24(17 Mar 1969). GEOTHERMAL RESOURCES; LEGAL ASPECTS; GEOTHERMAL ENERGY; NATURAL STEAM; OWNERSHIP RI GHTS

455 WATER SUPPLY: ECONOMICS, TECHNOLOGY, AND POLICY. Hirshlelfer, J.; de Haven, J.C.: Milliman, J.W. Chicago; University of Chlcago Press (1969). 400p.

An at tempt is made in this book to effect a major change, rather than merely a marginal modiflcation in the trend of current practice and thought on water-supply problems. Since publication of the first edition of this book in 1960 , the authors have re-examined water developrents in their two major case-study areas: New York City and Southern Californla. The evaluatlons and recommendations of the authors from the original book are further discussed here in twelve chapters: The Water Problem; Dut Hater Resources: The Present Picture; The Economics of Utillzation of Existing Hater Supplies; Criticisms of Market Allocations; The Polltical Allocation Process; Municlpal Water Rates; Investment in Additlonal Water Supplies: The Practical Logic of Investment Effclency Calculations;

Technologleal Features and Costs of Alternative Supplies of Water; Water Law: Government Discretion or Property Rights; New York's - Water Crisis'i: Case Study of a Crucial Decision: Water for Southern California: Case Study of an Arid Region: and Some Controversial Conclusions and Their Implications. ( $\mathrm{MCW}$ )

456 REICH, ARTHUR E. AND CAROLYN C. REICH US COMMISSION OF INTERNAL REVENUE, U.S. TAX COURT, JULY 31, 1969. Tax Court Rep:; 52: 700$717(1969)$.

The petltioners particlpated in ventures to drill for and exploit geothermal stean. One of these ventures was successful and the resulting wells produced sufficlent steam to supply electrical generating plants. One of the petitioners clalmed percentage depletion against the gross income it received from steam production in the successful venture. All the petitioners expensed the Intanglble costs of drilling and developing geothermal steam wells. Held, the petitioner which particlpated in the successful venture is entitled to deduct percentage depletion at the rate of $27,1 / 2$ percent against gross income it recelved from stean production. Held, further, all petitioners are entitled to expense the intanglble costs of drilling and developing geothermal stean wells.

457 NEVADA'S GEOTHERMAL RESOURCES. Schilling, J.H. NV Business Rev.: 3-5 (Aug 1968). NEVADA; GEOTHERMAL RESOURCES;NATURAL STEAM;
POWER GENERATION; LEGAL ASPECTS

458 INTERNAL REVENUE SERVICE REGULATIONS. Fed. Reglst. (Wash., D.C.); 33: 317-321(26 Jul 1968).

Text of the Internal Revenue Service Regulations pertalning to mineral depletion allowances are given. (PCS)

459 STATE, FEDERAL LAWMAKERS WEIGH GEOTHERMAL LEASING. Electr. World: 167: 38(6 Mar 1967). GEOTHERMAL FIELDS;LAND LEASING; LEGAL ASPECTS; GEOTHERMAL ENERGY

460 TOHARD A THEORY OF PROPERTY RIGHTS. Demsetz, H. (Unlv, of Chlcago). An. Econ. Assoc. Pap. and Proc.: 57: 347-359(Mar 1967). An econonic theory of property pights is presented in three parts: the concept and role of property rights in social systems; guidance for investigating the emergency of property rights; and some principles relevant to the coalescing of property rights into particular bundles and to the determination of the ownership structure that will be associated with these bundles. (PCS)

461 GEOTHERMAL ENERGY LANDS DUTLINED.

Calif. Div. Mines, Geol., Mineral Info. Serv.: 20 : No. 6, 5B, 72(1967).

USA;GEOTHERMAL RESOURCES; LEGAL ASPECTS; LAND RECLAMATION

462

CALIFORNIA'S GEOTHERMAL RESOURCES. Sacramento; State of Callfornia, Jolnt Legislative Committee on Tidelands (1967). $194 \mathrm{p}$.

Legal and technological status. CALIFORNIA; GEOTHERMAL RESOURCES;GEOTHERMAL EXPLORATION; LEGI SLATI ON

463 CALIFORNIA LAHS FOR THE CONSERVATION OF GEOTHERMAL ENERGY, AN ACT TO AMEND THE HEADING OF CHAPTER 4, AND TO ADD TO CHAPTER 3, DIVISION 3, OF THE PUBLIC RESOURCES CODE, RELATING TO GEOTHERMAL RESOURCES. Sacramento; State of Callfornia (1967). vp.

CALIFORNIA ; LAWS; GEOTHERMAL ENERGY REGULATIONS ; MANAGEMENT ; GEOTHERMAL EXPLORAT ION; LAND LEASING

464 DISPOSITION OF GEOTHERMAL STEAH - 1967. Washington, DC; US Congress. House. Comnlttee on Interlor and Insular Affalrs (1967). 244p. USA;GEOTHERMAL RESOURCES;NATURAL STEAM; LEGISLATI DN; GEOTHERMAL ENERGY ; HEARINGS

465 GEOTHERMAL STEAM LEASING; HEARINGS BEFORE SUBCOMMITTEE DN MINERALS, MATERIALS AND FUELS ON S. 23 AND S. 912, MARCH 12-22, 1970. Washington, DC; US Congress. Senate. Comalttee on Interlor and Insular Affalrs (1967). 133p. USA; GEDTHERMAL RESOURCES;NATURAL STEAM; GEOTHERMAL FIELDS;LAND LEASING;LEGISLATION

466 GEOTHERMAL STEAM ACT OF 1966 (S. 1674); MEMORANDUM OF DISAPPROVAL, 14 NOV 1966. (US President). Weekly Compilation of Presidential Documents; 1699(21 Nov 1966). USA; GEOTHERMAL RESOURCES; LEGISLATION: GEOTHERMAL STEAM ACT

467 GEOTHERMAL STEAM. Washington, DC; US Congress. House. Committee on Interfor and 
Insular Affairs (28 Sep 1966). 36p.

USA; GEOTHERMAL RESOURCES: EXPLOI TATION; NATURAL STEAM; LEGISLAT ION; GEOTHERMAL ENERGY; GEOTHERMAL STEAM ACT

468 GEOTHERMAL POWER IN CALIFORNIA, A RESPONSE TO SENATE RESOLUTIDN NO. 138 , RELATING TO THE USE OF GEOTHERMAL POWER FOR THE TRANSPORTATION OF WATER OVER THE TECHACHAP MOUNTAINS. Campbell, I.; James, L.B.; Dakeshott, G.B.; RIchter, R.C.; Koenlg; J.B. Sacramento; Calif. Dept. Hater Res. (1966). 8p.

Research proposal s. CALIFORNIA; GEOTHERMAL ENERGY;RESEARCH PROGRAMS ; GEOTHERMAL RESOURCES; WATER; TRANSPORT; LEGAL ASPECTS; LEGISLATION

469 LEGAL PROBLEMS OF THE GEOTHERMAL INDUSTRY. Brooks, J.W., Jr. Univ. NM Law School, Nat. Res. J.: 6: No. 4, 511-41(1966). GEOTHERMAL ENERGY;ECONOMI CS;GEOTHERMAL FIELDS ; NATURAL OCCURRENCE; LEGAL ASPECTS; GEOTHERMAL EXPLORATION; GEDTHERMAL RESOURCES; LEGISLAT ION

470 GEOTHERMAL RESOURCES IN CALIFORNIA. Koenig, J.B. Calli. Div. Mines, Geol., Minerai Info. Serv.; 19: No. 6, 94-5(1966). CALIFORNIA;GEOTHERMAL RESOURCES;MINERAL RESOURCES; GEYSERS GEOTHERMAL FIELD;SALTON SEA: GEOTHERMAL EXPLORATION ; EXPLOITATION: ENVIRONMENTAL EFFECTS; CORROS IVE EFFECTS;SCALING; LEGAL ASPECTS; COST;ECONONICS ; HEARINGS ; GEOTHERMAL EXPLORATION; GOVERNMENT POLICIES; GEOTHERMAL ENERGY

471 DISPOSITION OF GEOTHERMAL STEAM. Washington, DC; US Congress. House. Conmittee on Interlor and Insular Affairs (1966). vp. USA; GEOTHERMAL RESOURCES; EXPLOI TATION; NATURAL STEAM; LEGISLATION; LEGAL ASPECTS GEOTHERMAL ENERGY;GEOTHERMAL STEAM ACT

472 SOME ASPECTS OF PROPERTY RIGHTS. Demisetr, H. (Univ. of Chicago). J. Law Econ.: 9: 61-70(1966).

Some aspects of property rights are discussed as they bear on the two basic economic laws which state that (1) demand curves are negatively sloped and that (2) queues will tend to be eliainated by a price that is free to fluctuate. Traditional approaches are treated as well as some whlch heve been ignored in the past since property rights have not been treated explicitly. (PCS)

473 USE OF GEOTHERMAL HEAT POTENTIAL. Bible, A.H. Public Util. Fortn.: 73: 54-5(29 Apr 1965 ).

USA;GEOTHERMAL RESOURCES; GEOTHERMAL ENERGY; POWER GENERATION:LEGAL ASPECTS;LEGISLATION

474 (PD--218830, PP 90) GEOTHERMAL STEAM ACT OF 1965 (A BILL TO AUTHORIZE THE SECRETARY OF THE INTERIOR TO MAKE DISPOSITION OF GEOTHERMAL STEAM AND ASSOCIATED GEOTHERMAL RESOURCES ). 1965 .

Exploration and exploitation of geothermal resources in arid and semlarld lands.

USA; GEOTHERMAL RESOURCES; LAND LEASING; REGULATI DNS ; LEGAL ASPECTS; LEGI SLATIDN; NATURAL STEAM; PUBLIC LANDS;GEOTHERMAL STEAM ACT

475 PUBLIC HEARING ON GEOTHERMAL ENERGY AND ASSOCIATED MINERAL RESOURCES. Palm Springs Ch; State of California, Senate Fact-Finding
Committee on Nat. Res. (1965). 177p.

CALIFORNIA; GEOTHERMAL ENERGY; HEARINGS; MINERAL RESOURCES ; GEOTHERMAL EXPLORATION

476 CALIFORNIA LAWS FOR THE CONSERVATION OF GEOTHERMAL ENERGY, (CHAPTER 1483, STATUTES OF 1965), AN ACT TO ADD CHAPTER 4, DIVISION 3, TO THE PUBLIC RESOURCES CODE, RELATING TO GEOTHERMAL ENERGY AND ASSDCIATED RESOURCES. Sacramento; State of Calffornia (1965). vp. CALIFORNIA; GEOTHERMAL ENERGY; LAWS; REGULATIONS ; LEGISLATION

477 INITIAL EXPLORATORY UELL COVENANT.

III. 011 and Gas Law: 5: 59-63(1964).

Implied covenants from oll and gas well drilling leases are discussed with precedents for breach and its remedy, and well abundament theory. (PCS)

478 ACQUISITION OF GEOTHERMAL RIGHTS: PROPOSED METHODS. Randall, G.C. Idaho Law Rev.; 1: No. 1, 49-66(1964).

It is shown that in most western states the geothermal power developer is confronted initially with the problem of acquiring valid rights to the hot water or steam. He nust choose between attempting to acquire such rights through placer location, 011 and Gas Leasing Act, or under state water appropriation laws. Case studies are presented to lilustrate the uncertain situetion a prospective developer laces. It is suggested that the placer location is the best and safest way to acquire hot water or steam.

479 ANALYSIS OF THE USUAL OIL AND GAS LEASE PROUISIONS, Gregg, D.H. South Tex. Law J.: 5: No. 1, 1-46(Uin 1960).

The usual provisions of oll and gas leases are discussed using the most common Producer's 88, revised as a model. The Importance of each is stressed. Extensive Texas case declsions affecting each lease provision are cited. (PCS)

480 PROPERTY THEORIES AFFECTING THE LANDOWNER IN A NEW OIL AND GAS PRODUCING STATE. Cohen, H. Ala. Law Rev.: 10: v(1958).

This article surveys legal theorles and statutes which have offected the landowner's legal position concerning oll and ges beneath his subdivision of land before and after oll activity has taken place. (PCS)

481 EVOLUTION OF OIL AND GAS LAW. Merrill, M.H. Miss. Law J.: 13: No. 3, 281-291( Mar 1941).

This survey of case law in condensed forn reveals a development of scientific, industrial, and business experience that united to produce the present-day law. Constant movement from extreme individual ism to emphesis on the common Interest in the proper exploitation and use of important minerals in the legal decislons of the present time is detalled by case citations. Rules have modifled over the years but the American Drean Is still preserved. (PCS)

482 ECONOMICS OF EXHAUSTIBLE RESOURCES. I. THE PECULIAR PROBLEMS OF MINERAL WEALTH. Hotelling, H. (Stanford UnIV., CA). J. Polit. Econ.; 39: No. 2, 137-175(Apr 1931). The discussion is confined in scope to absolutely irreplaceable assets. Toples Include peculiar problems of nineral wealth; 


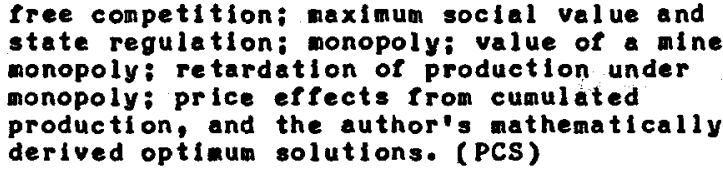

483 (CONF-720742-) UnC1 PROCEEDINGS OF THE ENERGY RESEARCH PRIORITIES CONFERENCE HELD AT BERWICK ACADEHY, SOUTH BERHICK, MAINE, JULY 30--AUGUST 4, 1972. (National Science Foundation, Washington, D.C. (USA)). [nd]. 161p.

From Energy research priorities conference; South Berwlek, Maine, USA (30 Jul 1972). ENERGY POLICY; MEETINGS;ENERGY CONSERVATION: ECONOMIC POLICY; SOLAR ENERGY; GEDTHERMAL ENERGY; COAL; ENERGY CONUERSION ; LMFBR TYPE REACTORS; REGULATIONS; REGULATORY GUIDES; FUSION REACTIONS; COST BENEFIT ANALYSIS;RESEARCH PROGRAMS: ENVIRONMENTAL IMPACTS;ENERGY CONSUMPTION; PETROLEUM;ELECTRIC POWER;USA;NUCLEAR ENERGY;US AEC; MANAGEMENT ; RESERVES; OIL SHALES;OIL SANDS; SYNTHETIC FUELS; URANIUM ORES;ENERGY
484 (LA-UR--73-570) UnCl SOME INTERFACES IN RESOURCE UTILIZATION. ReInig, L.P. [nd]. Contract U-7405-eng-36. 16p. (CONF-730440-1). Dep. NTIS $\$ 3.00$.

From Symposium on responses to the dilema: environmental quality vs. economic development: Lubbock, Texas, USA (19 Apr 1973).

Geothermal energy, energy transmisslon, and desalination of underground water in New Mexico. ECONOHICS;GEOTHERMAL ENERGY;NUCLEAR POWER ; DESALINATION ; ENERGY SOURCES; HUMAN POPULATIONS ; FOSSIL FUELS ; ENVIRONMENT ; BRINES ; LEGAL ASPECTS;ELECTRIC POWER;NEW MEXICD; TECHNOLOGY UTILIZATION;GROUND WATER

485 RECENT DEVELOPMENTS IN THE TAXATION OF GEOTHERMAL EXPLORATION. Elsenstat, S.M. San Francisco, CA: Geothermal Energy Inst. ([nd]). 4p.

TAXES; GEOTHERMAL EXPLORATION; LEGISLATION; REGULATIONS ; LAND LEASING; FINANCING 


\section{CORPORATE INDEX}

In the Corporate Index, report 1 iterature Is indexed using the name of the organization or institution reaponsible for Issuing the report. Headings are provided for all report literature and for published IIterature for which corporate epproach is especially desirable, e.g., symposium and conference proceedings.

Each entry under corporate heading olves the report itle and the citation number. Report numbers, if applicable, are given in parentheses at the end of the entry.

DOE Energy Inforation Data Base: Corporate Author Entrles (TID-4585) Is used in the stendardization of corporate entrlea. TID-4585 is aval lable ror purchage fron the National Technical Infornation Service (NIIS), U. S. Department of Commerce, Springfield, Virglnia 22161.

AEROJET NUCLEAR CO., IDAHO FALLS, IDAHO (USA). IDAKO NATIONAL ENGINEERING LAB.

National progran definition study for the non-electrical utilization of geothermal energy, 173 (ANCR--1214)

ARHY WAR COLL., CARLISLE BARRACKS, PA. (USA)

Energy crisis: revision in U.S. policy to preserve national security, 330 (AD-778886)

BATTELLE COLUMBUS LABS ., OHIO (USA)

Review of the Project Indegendence report submitted to Deflee of Energy Research and Developnent, Natlonal Selence Foundation, January 10, 1975, 195 (PB--238791)

BUREAU OF LAND MANAGEMENT, LAKEVIEW, OREG. (USA). LAKEVIEW DISTRICT

Sumer Lake Basin geothermal leasing: Environmental Analysis Record, 51 (NP--21256)

BUREAU OF MINES, WASHINGTON, D.C. (USA)

Geothermal energy: economic potential of three sites in Al aska, 200

\section{C}

CALIFORNIA ENERGY RESOURCES CONSERVATION AND DEVELOPMENT COMMISSION, SACRAMENTO (USA)

Proposed energy research end development progran: ficcal year 1976/77. Call fornia Energy Resources Conservation and Developaent Comission, 73 (NP--21008) CALIFORNIA STATE OFFICE OF SCIENCE AND TECHNOLOGY,

SACRAMENTO (USA)

Callfornia Energy Workshop: developing plan of action to neet the energy crists in Callfornia, 323 (PB237045 )

CALIFORNIA UNIV,, BERKELEY (USA), LAWRENCE BERKELEY LAB

Proceedings of the geothermal power development conference, Univeralty of Callfornta, Berkeley, June 18, 1974, 271 (LBL-3099)

Public opinion concerning geotheral developwent in lake County, California, 65 (LBL--4447)

Public opinton in Cobb Valley concerning geotherabl development in Lake County, Callfornia, 50 (LBL--5204)

CALIFORNIA UNIV. LIVERMORE (USA). LAWRENCE LIVERMORE LAB.

Regulatory aspects of geothermal energy development in the Salton Sea/Inperial Valley Area, 186 (UCID--16807)

CALIFORNIA UNIV., RIVERSIDE (USA)

Procesdings: natlonal conference on geothermal energy. Palm Springs, Callfornta, May 10--11, 1973. Volume II. 335 (NSF/RA/N--73-117(Vol.2))

CALIFORNIA UNIV., RIVERSTDE (USA). CENTER FOR SOCIAL AND

BEHAVIORAL SCIEHCE RESEARCH

Some issues regarding regulatory poliey, political participation, and soclal Implications of geothermal resource development in the Imperial Valley, 74 (NP21381)

COASTAL ENUIRONMENTS, INC, BATON ROUGE, LA. (USA)

Envlronmental assessment of proposed geothermal well testing in the Tigre Lagoon Oll Field, Vermilion Parlsh, Loulsiana, 68 (TID--27034)

COMMITTEE ON INTERIOR AND INSULAR AFFÁIRS (U.8. BENATE),

HASHINGTON, D.C.

Energy research pollcy alternatlves. Hearing pursuant to 8. Res. 45, national luels and energy policy atudy, on existing federal onergy research and development polleles and future technological options, U. S. Senate, June 7, 1972, 403

Geotheraal energy resources and research. Hearings before the Conmittee on Interior and Insular Affalrs, United states senate, pursuant to $S$. Res. 45 , national fuel and energy pollcy tudy, Ninety-second national fuel and energy pol tcy study, Ninety-secon energy resources in our nation's future energy economy. June 15 and $22,1972,407$

Presidential energy statenents. Printed at the request of Henry M. Jackson, Chal rman, Combittee on Interior and Insular Affairs, United Stetes Senate, Ninety-Third Congress, First sesilon, purouant to $\mathrm{S}$. Res. 45, national fuel and energy pollcy tudy, 364

summary report of the Cornell workshop on energy and the envi ronment. Hearing pursuant to 8 . Res. 45, a national fuels and energy pollcy study, U. S. Senate, February $22--24,1972,404$

COMMITTEE ON SCIENCE AND ASTRONAUTICS (U.S. CONGRESS HOUSE, HASHINGTON, D.C.

Geotheraal energy. Hearings before the subconittes on eneray of the Conmittee on Sclence and Astronautics. United States House of Representatives, Ninety-Third Congress, First Session on H.R. 8628, H.R. 9658, September 11, 13, and 18, 1973, 379

DEPARTAENT OF THE INTERIOR, WASHINGTON, D.C. (USA)

Final envi ronental ctatenent for the geothermal leasing program. Volume I. Promulgation of leasing and operating regulations, 360 (NP--20212)

Geothermal Leasing Progran, 396 (PB--208954)

Geothermal Leasing Prooran. Volume 1. Pronulgation of leasing and opereting regulations. Final environmental impact atatement, 326 (EIs-CA-73-1681-F1)

Geotharaal Leasing Program. Volume I1. Leasing of geotheral resources in three Callfornia ereas. Final environmental impact statement, 327 (EIS-CA--73-1681-F2)

Geotheral Leasing Program. Volume III. Appendices A through H. Proposed geothermal, leasing, and operating regulations. Final environmental Impact statement. 328 (EIS-CA-73-1681-F-3)

Geothermal Leasing Progran. Volune IV. Appendix I. Comments on draft impact statement and proposed regulations. Final environmental impact tatement, 329 (EIS-CA-73-1681-F-4)

Geothermal leasing program. (Supplement to draft dated 6 Oct 1971, $P B--203102-D), 397$ (PB--208954)

Geothermal leasing progrem, considers impect of leasing and operating regul ations to inplenent the Geotheraal Stean Act of 1970 and leasing of 3 areas in Callfornia. Stean Act of 1970 and leasing of 3 areas in Callfornia.
Draft environmental impact tatement, 421 (PB--203102-

D)

Mining and minerals pollcy: 1976 blcentennial edition, 42 (NP--21355)

Report to the Congress. Problens in identifying. developing, and using geotheral resources, $189^{\circ}$ (TID-26866)

DOW CHEMICAL CO., FREEPORT, TEX. (USA)

Analysis of the potential use of geothermal energy for power generation along the Texas Gult Coast, 150 (NSFRA-N--74-246) 
$\mathbf{E}$

ENERGY RESEARCH AND DEVELOPMENT ADMINISTRATION, OAK RIDGE, TENN. (USA). TECHNICAL INFORMATION CENTER

Geotheraal resources: exploration and exploitation. A bibllography 43 (TID--3354-R1)

ENERGY RESEARCH AND DEVELOPHENT ADHINISTRATION, WASHINGTON, D.C. (USA)

Natl onal plan for energy research, development and demonatration: creating energy cholces for the future. Volume 2. Prograa Implementation, 84 (ERDA--76$\left.1\left(V_{01} \cdot 2\right)\right)$

ENERGY RESEARCH AND DEUELOPHENT ADMIMISTRATION, WASHIMGTON,

D.C. (USA). DIV. DF GEOTHERMAL ENERGY

Envi ronmental assessment fof proposed geothermal weII testing in the Tigre Lagoon oil Field, Verilit on Parlsh, Loulsiana, 68 (TID-27034)

Susanvilie Geothermal Energy Project. Workshop proceedings final technical report, 40 (SAN--1077-4)

FEDERAL ENERGY ADMINISTRATION, WASHIMGTON, D.C. (USA)

Project Independence. Final task force report: geothermal energy, 250 (NP-20944)

FEDERAL ENERGY REGULATION STUDY TEAK (USA)

Federal energy regulation: an organizational etudy, 262 (TID-26559)

FEDERAL POUER COMMISSION, UASHINGTON, D.C. (USA)

Statexent at hearings before the Conalttee on Interior and Insular Affairs, 433

FEDERAL TRADE COMMISSION, WASHINGTON, D.C. (USA)

Stafe report to the Federal Trade Commision on federal energy land polfcy: effleiency, revenue, and competition, 152 ( PB-246663)

FEDERAL TRADE COMMTSSION, UASHINGTON, D.C. (USA). BUREAU OF COMPETITION

Mineral leasing on Indian lands: report to the Federal Trade Comission 151 (PB--246568)

FUTURES GROUP, GLASTONBURY, CONN. (USA)

technology assessaent of geothermal energy resource development, 184 ( $\mathrm{PB}-246241$ )

$\mathbf{G}$

GENERAL ACCOUNTING OFFICE, WASHINGTOH, D.C. (USA)

Report to the Congress: problems in Identifyling developing; and using geothermal resources, 190 (NP20694)

GEOLOGICAL SURVEY, WASHINGTON, D.C. (USA)

Classiflcation of public lands valuable for geothermal stean and assoclated geothermal resources, 434 GEOTHERMAL ENERGY INST., SAN FRANCISCO, CALIF. (USA)

Sumary guide to the institutional probleas confronting the geothermal energy industry, 244 (CONF-741145--1)

HAHAII STATE DEPT. OF PLANNING AND ECONOMIC DEVELOPMENT, HONOLULU (USA)

state polley considerations for geotheral development in Hawall, 185 (PB--243467/8ST)

IOWA ENERGY POLICY COUNCIL, DES MOINES (USA)

Energy: 1975. The first annual report of the Iowa Energy Policy Council, 194 (NP--20667)

Jet PROPULSION LAB., PASAdENA, CALIF. (USA)

Geotheraal energy in California: status report, 44 (JPL5040-25(Rev.A) (APP.))

Program definition for the development of geotheraal energy. Volume I. Background and program definition summary, 159 (JPL--5040-6(Vol .1))

Program definition for the development of geothermal energy. Volume II. Progran definition development rationale and subprogras descriptions, 160 (JPL--5040rationale and
G(Vol.2))

Program definition for the development of geotheral energy. Volune III: Appendixes, 161 (JPL--50406(Vol.3)

JOINT COMMITTEE ON ATONIC ENERGY (U.S. CONGRESS),

WASHINGTON, D.C.
America's energy potential: a sumary and explanation prepared by Congresanan Morris $K$. Udall, Chalrman. subcomit tee on the environient for use of the Comittee on Interior and Insular nefal of of the U.S. House of Representatives, MInety-Third Congress, First Session, Detober 1973, 363

JOINT ECONOMIC COMMITTEE (U.S. CONGRESS), UASHIMGTON, D.C.

Potentlel for energy production from geotheraal

resources. Report of the Subcomittee on Vater and

Power Resources, Committer on Interior and Insular

Aftalrs, Ninety-Third Congress, First Session; Decebber 1973, 378

MITRE CORP., MCLEAN, VA. (USA)

Geothermal energy resource utilization progras planning. 66 (NTR--7137)

$\boldsymbol{N}$

NATIONAL CONFERENCE OF STATE LEGISLATURES, DENVER, COLO. (USA)

State polleles for geothermal development, 85 (NSF/RA760230

NATIONAL SCIENCE FOUNDATION, MASHINGTON, D.C. (USA)

Proceedings of the energy research priorities conference held at Berwick Acadeny, South Berulek, Malne, July 30-August $4,1972,483$ (CONF-720742--)

NATIONAL TECHNICAL INFORMATION SERVICE, SPRINGFIELD, VA. (USA)

Geothermal energy. Volume 2. 1975-Aprll 1976 (eftations from the Englneering Index data base). Report for 1975-Apr 1976, 53 (NTIS/PS-76/0465)

Geothermal energy. Volume I. 1964--April 1975 (citations Irom the NTIS data base). Report for 1964-Apr 1975 . 52 (NTIS/PS--76/0462)

OFFICE OF TECHNOLOGY ASSESSMENT (U.S. CONGRESS), WASHINGTON, D.C.

An analyals identifying issues in the $\mathrm{flscal}$ year 1976 ERDA budget, 191 (PB--244863)

An analysis of the ERDA plan and progran, 153 (PB-250636)

PURDUE UNIV., LAFAYETTE, IND. (USA) - AUTOKATIC CONTROL CENTER

Geothermal resource characteristlcs, exploration coneiderations, and property acquilition techniques, 270 (CONF-741145--3)

TEXAS GDUERNOR'S ENERGY ADVISORY COUNCIL AUSTIN (USA) Inpact of state and federal lav on devel opment of geothernal resources in Texas. Project L/R-9, Iinal report, 254 (NSF-RA-N--24-244)

TEXAS UNIV:, AUSTIN (USA). CENTER FOR ENERGY STUDIES Proceedings of second geopresaured geothermal energy conference, Aust In, Texas, February 23--25, 1976. Volume $V$. Legal, Institutional, and environmental, 80 (CONF-760222--P5)

u

USAEC, WASHINGTON, D.C.

Geothermal energy program. Subpanel report VIII used in preparing the AEC Chalraan's report to the President. 325 (WASH-1281-8)

Nation's energy future. A report to Richard M. Nixon, President of the United States, 322 (UASH--1281)

WESTERN STATES WATER COUNCIL, SALT LAKE CITY, UTAH (USA) Western states water requirements for energy development to 1990,249 (NP--20555)

WYOMING GEOLOGICAL SURVEY, LARAMIE (USA)

Geothermal resources, present and future demand for power and legislation In the state of Hyoming. Public information series. 1, 67 (NP--21229) 


\section{AUTHOR INDEX}

Authorgl surnames are indexed in the corm appearing in the abstracted publication: glven names are reduced to Initials. Each author entry glves the publication title and the citation number. Report numbers, if applicable. are glven in parentheses at the end of the entry. For publ lcations with auti authors, an author entry is provided for each. Entries for the second and succeding author give reference to irst author.

Because of problems involved in the aechanical preparation of this index, al accent arks are oultted. Changes in spelling introduced as asult of accent omission follow standard conventions.

\section{A}

AHERN, W., Energy alternatives for Callfornia: paths to the future, 147

AIDLIN, J.H. Development of geotheraal laws and regulations, 302

Federal Energy Administ ration hearing on western reglonal rasource devel opment, 246

Review of ome of the legal problems in geothermal development, 413

United states law as it effects geothereal development, 125

ALLEN, D.R., Earth' heat tapped for geothermal power development, 420 Legal and policy aspects of geothermal resource development, 398

ANDERSEN, S.0., Benefits and coats to I indowners from geotheraal resource lesse and development, 140

Envi ronmental lapacto of jeotheraal resource development on commercial egriculture: ase study of land use conflict, 131

ANDERSON, D., Flow chart of critical path In geothermal exploration, 343

ANDERSON, D.N.. Compendium of rirst day papers presented at the First Conference of the Geothermal Resources Councll, El Centro, Callfornia, Feb 1972, 412

Geothermal lavs and regulation in the vestern United states, 296

Geothermal resources In Californis, 408

Proceedings of the workshop on environmental apects of geothermal resources development. 20-22 September 1974, 316

summary of Section XII: legal and institutional aspects, 107

See KOENIG, J.B. 113

ARI SHUNANDAR, A., SEe HOESNI, A.H., 435

ARHSTRONG, B., Role of pubile lands in geotherwal energy, 199 (CONF760612 - pp 327-330)

ATCHISON, S., Geothermal power: itrangled by red tape, 169

AUSTIN, C.F. Technical overview of geotheral resources, 11
AUSTIN, G.F., Geotheraal sclence and technology: ational program, 432

AUSTIN, W.H. JR., See AUSTIN, G.F., 432

AXTELL, L.H., SEe ANDERSON, D.N., 408, 412

- AXTMANN, R.C., Envi ronmental iapact of a geothermal power plant, 188

BALZHISER, R.E., SE STARR, C., 405 BANWELL, C.J., Geothermal energy and its usea: technical, economic, environmental, and ligal espects, 110

BARBIER, E., Environmental Impact statement for the Geothermal Leasing Prograi, 392

BARNEA, J., Mul tI purpose geothermal resource development: an overview, 114

KultI-purpose geothernal resource development: an overview, 91

Some reflections on the history of the United Netions and U.S. Government geothermal activitles, 177

BARR, R.C., Geothermal exploretion: itrategy and budgeting, 181

Sumary of section XI: conomic and financial aspects, 108

BATES, D.H., Federal organization for nonnuclear energy research and development activities of departments and igencles other departments and ogencles other
than ERDA: FY 1976, 175 (NP-20699)

BATES, M.R., Legal and institutional rectors. Geothermal research study In the Salton sea region of Callfornte, 233

BATHGATE, M.B., SEe CARR, R.B., 59

BENSON, F.J. Engl Ineering manpower and energy needs. IV. Federal pol feles have an Impact, 149

BIBLE, $A$. Geotheral Steam Act of 1970,440

BIBLE, A.H., Use of geothermal heat potentlal, 473

BJORGE, K.R., Devel opment of geothermal resources and the 1970 Geothermal stean Act: lav in Gearch of definition, 318
ANK, B., See LAERHAN, K.H., 55

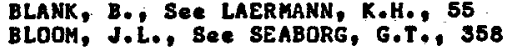

BLOOHSTER, C.H. Potentill netional benefits of geothermal electrical energy production from hydrothermal resources in the Hest, 97

BOCK, R.S., 1977 guldebook to California taxes with special emphasis on relationship to Federal taxes, 25

BOTtGE, R.G., SE ROSENBRUCH, J.C., 200

BOURKE, R.L. SEE MARTIN, D.B., 202

BOUEN, R.G., Geotherral activity In 1971, 400 (PB--218830, Pp 23) Geothermal energy: potentially the Hest' wajor energy resource, 247

Geothermal exploration on public lands: when and under what conditions, 337
Public interest vs. private partlsanship in geothermal development, 178

SEe ANDERSON, D.N., 315

BOWMAN, H.D. Electric power, fuel development, and protection of the environment: legielation introduced in the 91st Congress, 451

BRANNON, G.M., Energy taxes and subaldies, 314

Studies in energy tax policy, 208

U.S. taxes on energy resources, 183

BRETZ, T.E. Rules and regulations relating to geothermal leases on Colorado tate owned lands, 292

BREUER, $W$., Why public policy iust support geotheraal development. 309

BREYER, S.G., Energy regulation by the Federal. Power Commission, 316

BRoIli, C., Summer Lake Basin geothermal leasing: Environmental Analysis Record, 51 (NP-21256)

BRoOKS, J.H., JR., Legal problens of the geothermal Industry, 469

BUCK, J.V., Regulatory, planning and policy aspects of geothermal energy development In Imperial County, California,

BURTON, W.A., JR., Geothermal resources legal and tax considerat I ons, 263

BURTON, H,A. JR., Geothermal resources: legal and tax considerat Ions, 291

BURUELL, C.C., SEe VEINBERG, A.M., 71

BUTLER, D.R. Cooperative efforts by industry and government to develop geothermal resources, 241 (NSF/RA/N-74-159, pp 331-334)

BUTLER, E., SEe PICK, J,B.,

BUTLER, E,H., Opinton about geothermal development in Inperial County, California, 1976. Final report,

CADY, D.P., Definition or an inctitutional atructure, 35 ( $S A N-$ 1077-4, pp XIII.1-XIII.10)

CAHRAMAN, I.H. Interrelationship between rederal, state, end locel reguletory agencles on the development of the geotheraa resource in Callfornia, 342

CAHRMAN, T.H. Interrelat lonship between Federal, State and Local Regulatory Agencles, 355

CAMPBELL, G.E., Geothermal well drilling end completion practices in callfornta inciuding casing and abandonment prograne and examples of blowouts, 308

CAMPBELL, I., Geothermal power in Callfornia, response to senate Resolution No. 138, relating to the une of geothermal pouer for the transportation of water over the transportation of water over CANES, H.E., Uitnesses for oll: the case agalnst dismemberment, 230 CANNON, H., See BROILI, C., 51 CARLSON, D.H, SEe STONE, R.T., 285 CARR, R.B., Iaperlal Valley 
federal law on development of geothereal resources in Texas. Project $L / R-9$, Pinal report, 254

nufronmental project, 59 (UCRL52000-76-5, PP 21-26)

CASTELLANOS, H.P. JR., Formation funding, and development of : small exploration company, 231 CHAFFIN, R.L., SEe HJRUATH, J.C., 419

CITRON, O.R., Inst I tutionel and environmental aspects of geothermal energy development, 1

Institutional and environmental aspects of geothermal energy development, 92

COCHRAN, N.P., SEe STARR, C., 405

COHEN, H., Property theories affecting the landowner in a new oll and gas producing state, 480

COLE, R.J., See SCHULLER, C.R., 144

CONOVER, R.D., Federal regulations and lease terms and thelr regulationship to state laws and regulations, 303

CRAIG, R.A., SEe GLOBE, S., 195

CRAWFÓRD, R.B., SEe CARR, R.B., 59

DALSON, J.K.. Alternative energy sourees for the UK, 77

DE HAVEN, J.C., SE HIRSHLEIFER, J., 455

DECKER, E.R., Geotheraal resources, present and future demand for power, and legislation in the power, and legislat Ion

Geothermal resources, present and future demand for power and legislation in the state of youling. Public information serles 1, 67 (NP--21229)

DEITCH, L., SEe GORDON, T.J., 184

SEe MASLAN, F, 128,243

DELLER, R.W., SEE DORFMAN, H.H., 79

DEHSETZ, H., Some a spects of property rights, 472

Toward a theory of property rights, 460

DENCH, N.D., Law and geothermal developeent in New 2ealand, 116

DENTON, J.C., Geotheraal resources research, 375

Geothermal resources research, 394 DEPAOLI, E., See BROILI, C., 51 DICK, J., Mineral leasing on Indian lands: report to the Federal Trade Conel is sion, 151 ( PB-246568)

DOCTOR, R., SEE AHERN, $\mathrm{H}_{1} 147$

DOLAN, H.K., SEe OLSON, H.J., 232, $251,270,69,76$

DORFMAN, M.H., Legal, Institutional, and environmental, 79 (CONF-760222$-P 1$, PP 47-72)

DOUGHTY, L., SEe BROILI, C., 51

DOUMANI, G.A., Energy from geothermal resources. Report prepared for the Subcomit tee on Energy of the Counittee on Sclence and Comittee on Sclence and
Astroneut Ics, U.S. House of Astronautics, U.S. House of Congress, Second Session, 289

DUFFETT, J.H., Energy crials: revision in U.S. polley to preserve national security, 330 (AD-778886)

DUNLDP, D.D., SEe DENTON, J.C., 375

DUTCHER, J.L., Geothermal stean pricing at the Geysers, Lake and Sonoma Counties, California, 100

DYAS, N.H., See DOUHANI, G.A., 289

EATON, G.P., Role of the U.S. Geological Survey In assesing the Nation's geothermal energy resources, 239 (NSF/RA/N--74-159, Pp 111)

ECCLI, S.. Alternative sources of energy: practical technology and phllosophy for a decentralized society, 213

EDSON, D.A., Susanville project requi rements, 37 ( SAN-1077-4, pP II.1-II.16)

EDUARDS, T., Inpact of state and
(NSF-RA-N-74-244)

Impact of state and federal law on devel opment of geothermal resources in Texas, 299

EISENSTAT, S.M., Geothermal

exploration and development in the United States:a a tax analysis under the internal revenue code, 117

Geothermal exploration and development in the United States a tax analysis under the Internal Revenue Code, 230

Geothermal tax considerations and shelters, 229

Recent developments in the taxation of geothermal exploration, 196

Recent developments in the taxation of geotheraal exploration, 310 Recent developments in the taxation of geotheraal exploration, 485

Reducing the risks in geothermal exploration: a tax update, 180

Tax treatment of exploring and developing geothermal resources, 334

EL-RAMLY, N., Geothermal power cononics: an annotated blbliography, 278

ELLISON, S.P., JR., Toward a natlonal pollcy on energy resources and mineral plant foods. (Special publication). 361 (PB--230248)

ELMER, D.B., Legal issues in the development of geopressured geothermal resources of Texas and Loul siana Gulf Coast (Summary), 31

Legal issues in the development of geopressured-goothermal resources of Texes and Loulsiana Gull Coast 81 (CONF-760222--P5, Pp vp, Part 1)

See VANSTON, J.H., 80

ENGEL, R.L., SEe BLDOMSTER, C.H., 97

EVERITTS, D.J., Rol of of te government in the development of a geothermal resource, 369

FANNIN, P., Law needed for geothermal energy, 268

FANNIN, P.J., Dinner Session. Thursday, 10 May 1973,339

FEEHAN, J.G., Energy crlsis and the consumer states, 332

FEFFER, A.P., See TAFT, M.I . 306 environientel impact tatement for the federal geothermal leasing prograns, 436

Federal tax polley and geothermal energy development, 331

Instl tutl onal, business, and financial aspects of the geothermal energy Industry. 252

Insti tutionel, business, and Inancial aspects of the geothermal energy Industry (abstract), 257

Sumary gulde to the Institutional probiens confronting the geothermal energy Industry, 244 (CONF-741145--1)

FINN, D.X., Summary gulde to the institutionel problems confronting the geotheraal energy industry. 283

FISHER, J.L., Energy choices and public pollcy, 158

FRANZEN, D.E., Property aystems in geotherwal resources: a critlque and recommendations, 118

FREELAND, T.F., SEe KLEEMAN, H.T., 120

FREEHAN, S.D., Energy: the new era. 273

FRIEDLANDER, G.D., Toward a national energy pollcy, 356

FRIEDMAN, A.E., Economics of the common pool: property rights in exhaustible resources, 439

FRI2, T.0., SEe STONE, R.T., 285

FRIZZELL, T.H., SEe MARTIN, D.H., 202

FUCHS, R.L., Geothe raal energy: the challenges that lie ahead (Part 2 of a two-part articie), 193
FINN, D.F.X. Coments on draft
GAGE, S.J., Federal energy/environmental research and development program, 212

GARDNER, R.J., Socio-economic codel. 38 (SAN--1077-4, PP XII.1-XII.34)

GARNISH, J.D., Geothermal energy as an 'al ternative' source, 54

GARSIDE, L.J., Geothermal exploration and development in Nevada, 409

GILLILAND, M.W., Energy analy's and public polley, 155

GILMORE, J.S., Boon towns may hinder energy resource development, 72

GLOBE, S., Review of the Project Independence report submitted to office of Energy Research and Devel opment, National Seience Foundation, Januery 10, 1975, 195 (PB--238791)

GLUCK, D., See BUCK, J.V., 4

GODHIN, L.H., Classiflcation of public lands valuable for geothermal stean and assoclated geothermal resou rces, 434

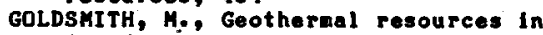
California-potentials and problems, 418

GOLDSTEIN, D.B., Unitization for geothermal resources: united we save, 17

GORDON, T.J., A technology assessment of geothermal energy resource development, 184 ( $\mathrm{PB}--246241)$

See MASLAN, F., 111, 128, 243

See WEINSTEIN, D., 126

GOTTLIEB, M.B., See STARR, C., 405

GRABBE, E.M., State pollcy considerations for geotheraa development in Hawail, 171

state pollcy considerations for geothermal development in Hawall. 185 ( PB--243467/8ST)

GREELEY, R.S., SE ZRAKET, C.A., 385

GREEN, P.S., Some l ssues regarding regulatory pollcy, political participation, and social implications of geothermal resource developaent in the resource developaent

some issues regarding regulatory policy. political participation and soclal implications of geotheral resource development in the Imperial Valley, 74 (NP-21381)

GREGG, D.H., Analysis of the usual ofl and gas lease provlal ons, 479 GREGORY, D.P., SEe STARR, C., 405

GREIDER, B., Grelder geothermal statement, based on testimony presented to Lt. Gov. Dymally Comittee, 62

Status of conomics and einancing geothermal energy power production, 227

GROVER, F.T., Geothermal energy resource ut llization prograt planning, 66 (MTR-7137)

GULICK, F.A., HIghlighte of energy related leglsiation in the 93rd Congress. Prepared at the request of Henry $M$. Jackson. Chairan, Conmittee on Interior and Insular Refalrs, United states Senate pursuant to $s$. Res. 45, 215

GUSTAVSON, T.C., See KREITLER, C.H.,

SeE VANSTON, J.H., 80

HAEFELE, HOLF, Energy systeas. I, HAENSCHKE, F., See LAERMAN, K.H., 55 HAGMAN, D., SEe BUCK, J.V., 4

HAIGLER, L.B., See GODWIN, L.H., 434

HALL, L.K., Perspective for the gith Congress, 311

HAMKER, H., SEe KRAMER, H.K., 14

HAWMERSMARK, H. SEe BROILI, C. 51

HAMMOND, A.L., Energy and the future. 362

HANSEN, D.C., Water confliets from the viewpolint of a regulator, 16 
HARRIS, R.W., Interstate environmental problens: gulde to water pollution and water scarcity, 317 HARRIS, U., See AHERN, U., 147 HARTZOG, N., See GULICK, F.A., 215 HAUGE, C.J.: See SLOSSON, J.E., 381 HAYMES, K.E. SeE KLEEMAN, W.T., 120 HELLER, H., Legal espects of the utilization of geothermal heat, 75 HEMINGWAY, R.H., Law of oll and gas, 441

HESS, H., Geothermal energy prospects and lifitations, 109

HILL, D., See BROILI, C., 51

HIRSHLEIFER, J. Wa ter supply: conomles, technology, and policy, 455

HOESNI, A.M., Geothermal energy prospects in relation to policy of regional ut llization of energy resources in Indonesia, 435

HOOK, J.W., Senate Judiclary Comittee HB 2040: April 30, 1975, Dregon, 172

HORVATH, J.C., Geothermal energy, its future and econonles, 419

HOTELLING, Hi, Econonlcs of exhaustibie resources. I. The peculiar problens of ilineral wealth, 482

HOWE, H., PGandE' geothermal power plant In California: the Geysers,

HUDSON, L., Salt water Is a aineral: ownership of a natural resource of increasing importance in ollproducling states, 417

HUTTRER, G.H., SEe FUCHS, R.L., 193

See KOENIG, J.B., 113

ICERHAN, L., SEE PENNER, S.S., 295 IGA, H., SE NAKAMURA, S., 122

JACKSON, H.K., S.1263, NatIonal Energy Research and Development Pollcy Act of 1973,359

JAMES, L.B., Se€ CAMPBELL, I., 468 JEBINS, A.B., Callfornla Energy Workshop: developing alan of action to met the energy crisis action to weet the energy crisis JEFFERY, U.D., SEe HARRIS, R. H., 317 JESKEY, J.C., SE CADY, D.P., is JOHNSON, C., Effects of geothermal development on the agricultural resources of the Imperial Valley. 6

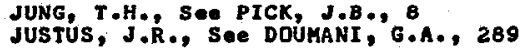

KaMINS, R., Preliminary report on legal and public policy etting for geothermal resource for geothermal resource

KAMINS, R.M., Geothermal development policy for an Isolated state: the case of Hawall, 119

Hauall geotheraal project, 192 SEe GRABBE, E.H., 171, 185

KAUFMAN, A., Economles of geothermal power in the United States, 449

KAUFMAN, S. SEe UILSON, J.S., 150

KITCHEN, G.J., Geothermal leasing practlces, 12

KLAFF, J.L., Energy and materials, 384

KLEEMAN, W.T., Technical assessment of the Impact of geopressure developnent in the Corpus Christ area of Texas, 120

KNUTSEN, C.A., Benefits of stiaulating geothermai energy development with tax and research subsidies, 143

KOENIG, J.B., Exploration and devel opment of geothe raal resources In the United States, 1968 to 1975,113

Geothermal resources in Californta, 470

See CAMPBELL, I., 468
KORNREICH, D., Se KAKINS, R., 279

KRAHER, M.K., Role of municlpalities in geothernal resource development, 14

KREITLER, C.H., Geotherad 1 resources of the Texas Gulf Const: environaental concerns arising from the production and disposal of geothermal waters, 83 (CDNF$760222--P 5$, pp vp, Part 3) Sec VANSTON, J.H., 80

KRIER, J., SeE BUCK, J.V., 4

KRIER, J.E.. SEe BATES, M.R., 233

KRISTOFERSON, L., Energy in society, 370

KRUGER, P., Development of the Nation's geothe raal energy resources. II, 154

Devel opment of the Nation's geothermal energy resources, 170 Geothermal energy, 90

Geothermal energy, 94

Geothermal resources research and technology, 245

NSF/RANN FY 1975 progran for geothermal resources research and technology, 187

See OTTE, C., 377

KRUTILLA, J.V., Towards a responslble energy policy, 197

KUNZE, J.F., Nati onal prograa definition study for the non- lectrical utllization of geothermal energy, 173 (ANCR-geothe

LAERMANN, K.H. Reply from the Federal Government concerning new primary energy sources, 55

LANDERS, W.S., Utility participation In geothermal energy source, 293

LARGE, A.J., Free lectriclty; plen to get more energy Irom heat Inside Earth moves forward a bit (Geothermal stean Act of 1970), 442

LARSON, I., Costs of geothermal energy development. Final report, January 1977, 3

LAH, S.H., SEe STARR, C., 405

LEH, M. Administrative laws of Calffornia's state Land Conml ssion: regulations pertalning to geothernal resources 349

Administrative law of Californials resources agency: portion of the directions for preparing environmental Impact reports, 350

Callfornia publle resources code: atatutes pertalning to geothermal resources, 348

Federal Geothermal steam Act of 1970: Public Law 91-581, 344 Geothermal resources - operations on public, acquilred and withdrawn 1 ands: notice of proposed rulemaking, 346

Leasing on public, ecquired and Ithdrawn lands: revision of proposed rule, 347

Majority opinion in the Relch case: question of depletion, 352

Proceedings: national conference on geothermal energy, Palm Springs, Callfornia, May 10-r11; 1973. Volume II, 335 (NSF/RA/N-73$117\left(V_{0} 1.2\right)$ )

Proposed rule making: geothernal resources - leasing on public, cauired and thdrawn lands: revision of proposed rule, 345

Terms, cond it 1 ons, standards, and application procedures for initial geothermal development: Inperial County, California; 351

LEDNARD, G.H., See AUSTIN, G.F., 432

LETLQW, $K .$, Devel opment of geothermal energy In the Gulf Coast: socloeconomie denographic and politicai considerations, 82 (CONF760222--P5, pp vp, Part 2 )

SE VANSTON, J.H., BO

LIBERMAN, L.H., Ene rgy conomlcs, 56

LINDSEY, M.K., Callfornia's geothernal lands: a legal framework for resource development, 121

Geothermal energy: legal problems
5 INDEX RIELKE

of resource development, 105

LIPSON, A., See AHERN, H., 147 Session. Thursday, 10 May 1973, 340

LOFTING, E.M., Multiector analysis of the Impact of geothermal development on the economy of Imperlal County, Califorhia, 28

LOHMAR, U., SEe LAERMANN, K.H., 55

LONGYEAR, A.B.. Characteristics of nine communities considering geothermal utilization, 39 ( 1077-4, Pp XVI.1-XVI.14)

Susanvilie Geothermal Energy Project overview, 36 (SAN--1077-4, PP I.1 I.6)

Susanville Geothermal Energy Project. Workshop proceeding: final technical report, 40 (SAN1077-4)

Susanvili. Geotheraal Utillty system, 41 (sAN-1077-4, pP XVII.1XVII.9)

LOPREATO, S.C., Sie LETLOW, K., 82

See VANSTON, J.H., 80

LOVELAND, W.D., Geothermal energy resources, 156 (CONF-750720--, PP 59-86)

LYONS, T. AdmInistrative requlrenents for development of geotheraal resources, 157

Appendix B: adainistrative requirements for development of geothermal resources, 49 (JPL5040-25(Rev.A)(APP.), PP B.1-B.11)

MACAVOY, P.H., See BREYER, S.6., 316

MARKUN, P.M., See CANES, H.E., 130

MARSHALL, W., Self-gufficlency in energy, 176

MARTIN, D.H., Montana energy policy tudy, 202

MARTINEZ, A.R., Energy policles of the world: Venezuela, 221

MASLAN, F., Economic and soclal aspects of geothermal energy resource development, 128

Insti tuti onal and environmental problens in geothermal resource development, 243 (NSF/RA/N--74159, PP 139-159)

Technology forecast of United States geothermal energy resource development, 111

See GORDON, T.J., 184

See UEINSTEIN, D., 126

MATTHOEFER, H., Reply by the Federal Government to a question concerning new primary energ sources ralsed In the Bundestag 57

MAUGH, I.H. II, See HAMMOND, A.L., 362

MAXFIELD, P.C., Incone taxation of geothermal resources, 20

MAYFIELD, L.G., SEe STARR, C., 405

MCCALEB, C.S., SEe CARR, R.B., 59

MCCORKACK, M.M., Protecting the envi rongient, 101

MCFARLAND, H.F., Energy development and land use in Texas. Final report on Project E/S-1: inpact on land use and value of aternatlve strategies for production, distribution, and utilization of energy in texas in the period 1974--2000, 211

MCKENZIE, H.F., SE BARBIER, E., 392

MCNAMARA, J.J., Constraints on geotherail development: tax and beyond, 19

MEADOWS, K.F. Department of the Interior final statement, 353 Geothermal world directory, 376 Geothermal world directory, 401 Geothermal world directory, 89 Idaho Legislature, 354

MEINECKE, R.. SEe LAERMANN, K.H., 55 MERINETHER, $\%$." SE LETLOW, K., 82 SE VANSTON, J.H., 80

MERRILL, K.H., Evolution of oll and gas law, 462

METZ, U.D.S SEe HAMMOND, A.L., 362

MIELKE, J.E., See DOUMANI, G.A., 289 
and withdrawn lands. II, 423 NER, S.S., Eneroy. Volume Demands, resources, lapact,

MILLIMAN, J.W., See HIRSHLEIFER, J. 455

MOIR, L.H., S SE DUTCHER, J.L., 100

MONTGOMERY, U.D., structure of the geothermal industry through 1974 , 238

SEe BATES, M.R., 233

MORRIS, D., SE AHERN, H., 147

MORRIS, D.N., California's energy future, 88

MORTON, R.C.B., Declsion statement of Secretary of Interior on

geothermal resources program, 267

MUFFLER, L.J.P., S०e GODWIN, L.H., 434

WUKHOPADHYAY, A.K., Economie and engineering implications of the Project Independence 1985 geotheral energy output goal and the assoclated sensitivity analysis, 96

MUSICK, J.D. JR,, S ee VRANESH, G., 15

NAKAHARA, T., See NAKAKURA, S., 122 NAKAMURA, S., Geothermal rights and problems of legisiation in Japan, 122

NASSIKAS, J.N., Statement at hearings before the Comaltee on Interior and Insular Aftalrs, 433

NEHRING, R., SEe AHERN, H., 147

NELSON, E.L., SE SEABORG, G.T., 358

NETSCHERT, B.C., Energy company: monopoly trend in the energy markets, 430 (PB--218830, PP 72)

NIXON, R.K. President's message on energy, 1973, 373

President's message on supply of energy and clean alr, al so fect sheet from office of the White House Press Secretary, 425

NORTHROP, W.F., Role of the State Lands DIvision in developing geotheral resources in California, 70

OAKESHOTT, G.B., SE CAMPBELL, I., 468 OLPIN, O., Sumary and concluding remarks, 24

OLSON, H.J., Geotheraal energy: an industry apprai sal, 232

Geothermal energy: an industry appraisal, 69

Geothermal energy: an industry appraisal, 76

Geothermal resource characteristics. exploration considerations, and property acquisition techniques, 251

Geothernal resource characteristics. exploration considerations, and property acquisition techniques, 270 (CONF-741145--3)

ORNANO, M.M., Energy politics of France, 78

OTTE, C., Geothermal: as we see it today, 253

Introduction: the energy outlook, 377

PACKUOOD, R., Packwood geothermal bill (Senate Bill S. 3392), 259

PAGE, R.T., See KRUTILLA, J.V., 197
PASQUALETI, M.J., Geographicai environiental analyals. Final report, 29

PEARL, R.H., Recent geothermal developments in Colorado, 174

PECK, D.L., Assessent of geothermal energy resources, 393

PECORA, H.T., Adainistration's energy message and program: the need for prompt development or a national energy pollcy, 406

Geothermal resources leasing and operations on public, acquired,
PETERSDN, R. SeE EL-RAKLY, N. 278

PETERSON, R.E., Relch case: econonic Implications of depletion allowances, 222

PICK, J.B., Population analysi relative to geothermal energy development, Imperial County, Cal ifornia, 8

SEe BUTLER, E.U., 7

PIERSON, D.E., Imperiel Valley's proposal to develop a guide for geotheral developnent within it: county, 240 (NSF/RA/N--74-159, PP 160-163)

Interdl sciplinary plannling for geothermal development at the county level, 99

PIVIROTTO, D.S., El ectric utility companies and geothermal power, 98 PostkA, H. Dther energy sources, 64 (CONF-760205--, PP 120-143)

PRONO, J.K., SEe CARR, R.B., 59

QUILLEN, J.H., Maxiaum and tImely commercial development of domestic geothermal energy, 179

\section{$\mathbf{R}$}

RADJA, V.T., See HOESNI, A.M., 435

RADLINSKI, W.A., GuIdeIl ines relative to pipelines and surface production quipment and to production and royalty measurement, equipment, and testing procedures (Order Nos. 6 and 7 ) 30

RAMSEY, P., SEe LETLOW, K., 82

SeE VANSTON, J.H, 80

RANDALL, G.C., Acquisition of geothermal rights: proposed nethods, 478

RAY, D.L. Nation's energy future. report to Richard $M$. Nixon, President of the United States. 322 ( HASH--1281)

REED, M.J., Ecomoni cs of geothermal exploration, 312

REINIG, L.P., Some interfaces in resource utilization, 484 (LA-UR-73-570)

RICHARDSON, A.S., SEe KUNZE, J.F., 173

RICHTER, R.C., SE CAMPBELL, I., 468

RIGG, J.B., JR., Af ternoon General Session, Friday, 11 May 1973, 341

RIOUX, R.L., See GODWIN, L.H., 434

RITTENHOUSE, R.C., $R$ and $D$ in generation: giving practical direction to diverse vilews, 145

RIVA, J.P., SE DOUMANI, G.A., 289

ROGERS, K., SEe ELMER, D.B., 81

ROGERS, K., SE ELMER, D.B., 81

ROOT, T.E., Contents of a geothermal lease: some suggestions, 87

Introduction and legal overview of geothermal resources, 10

ROSE, A. Econonie Impact of geothermal energy development, 5

ROSENBRUCH, J.C., Geothernal energy: econonic potential of three sites in Alaska, 200

ROWLEY, J.C., Geothermal energy development, 2

\section{s}

SACARTO, D.M., State polfcles for geothermal devalopment, 85 (NSF/RA-760230)

SAKAKURA, S., Government activity report on geothermal energy in Japan, 112

SANDQUIST, G.H., Envi rommentel aspects of nuclear etimulation, 380

SCHEFFLER, H., SEe LAERMANN, K.H., 65 SCHILLING, A.H., See SCHULLER, C.R.,

SCHILLING, J.H., Nevada's geothermal resources, 457

TES GARSIDE, L.J., 409

SEGEL, H., See BROILI, C., 61

SCHLUCH, P.J., Geothermal resources

jolnt ventures, 13

SCHLUCKEBIER, G., See LAERMANN, K.H.,

SCHULLER, C.R., Legal, Institutional, and political problems in producing electric power from geothermal resources in Callfornia, 144

SEABORG, G.T., Public polley toward environment 1973: a review and appraisal. Nuclear and other energy, 358

SEAKANS, R.C. JR., Geothermal energy research, development demonstration, and production: Federal guarantees on loans, 58

SEO, K.K., See EL-RAKLY, N., 278 See PETERSON, R.E., 222

SHEETS, G., See KAMINS, R., 279 SHEETS, G.M., Hawali geothermal law, 255

Hawali volcano energy, 336

Penultimate geothermal system in legal perspective, 269 (CONF740209--, pp 617-632)

Uitinate future of the geothermal energy law, 286

SHEPHERD, B.P. SE UILSON, J.S., 150

SIMON, G.D., SE SCHULLER, C.R., 144

SIPE, H.T., Callfornía public utilitles conmission. 146

SLOSSON, J.E., Publle and geologyrelated leglsiation in Californta, 1968-1972, 381

SMERNOFF, B.J., Energy policy interactions in the United States, 333

SHITH, M.F., Geothermal energyVolume 2. Search perlod covered: May 1975--April 1976. Citations from the NTIS Data Base, 137

Geothermal energy. Volune 1. Search period covered: . 1970 -. 1974. Citationa from the Engineering Index Data Base, 138

Geotherwal energy. Volume I. 1964April 1975 (citations from the NTIS data base). Report for 1964-Apr 1975, 52 (NTIS/PS--76/0462)

Geotheral energy. Volume 2. 1975April 1976 (citations from the Engineering Index data base). Report for 1975--Apr 1976, 53 (NTIS/PS-76/0465)

SNYDER, S.A., Geothermal sales contracts, 21

SPINRAD, B.I. SEe LOVELAND, W.D., 156

STAHL, E., See LAERMANN, K.H., S5

STARK, D., Lease of federal geotheraal energy: rocky road (abstract), 34

STARR, C., Longer-range technologícal potentials for energy development: an assessment of the prospects in new energy technology, 405

STEINBERGER, M.F., SEe GREEN, P.S. 142,74

STEPHENS, R.C., Federal role in geothermal resource development, 18

STEWART, B.H. JR., SEE HARRIS, R.W. 317

STONE, C.D., Geotheraal energy and the law. I. The federal lands nanagement progran, 224

STONE, R.T., Environmental planning for the geothermal leasing program on public lands, 285

Federal government leasing and operating regulations and environmental impact statements, 414

Governmental leasing regulations, 290

Implementing the federal geothermal stean act of 1970,429 (CONF710571--, pp vP, Paper 6)

Leasing of Federal geotheras resources, 242 (NSF/RA/N-74-159, pp 122-127)

STOVER, J., SEe MASLAN, F., 111

SUMAERS, H.K.. Geotherial: the problen of definition, 338 SUPTON, P.; See LINDSEY, H.K., 105

SUTER, V.E., Union 0Il testimony: Geysers Power Plant 12 hearing (California Public Utilities Comei selion), 256 
URANESH, G., Geothe rmal resources: water and other conflicts encountered by the developer alernative energy source which in

igathering teami, 15 of geothermal resources development, 22

THOMPSON, S., Sae BUCK, J.V.,

TOLL, D.R., Leglalative goals of - lectric companies in 1974, 264.

TOMPKINS, D.C., Power from the Earth: geothermal energy, 411

TONNESSEN, $K$. , Regulatory aspects of geothermal energy development in the Salton Sea/Iaperial Valley Area, 186 (UCID-16807)

TORFASDN, H., Law of Icel and as it affects geothermal development, afrect

TROWER, E.D., Overview of the Californila permitting process, 23

\section{v}

V, A brief outline of geotherwa regulatory agencies In the western United States, 304

VANSTON, J.H., Proceedings of second geopressured geothermel energy

conference, Austin, Texas,

February $23--25,1976$. Volume $V$ Legal, institutional, and Legal, institut lonal, and P5)

VERESPEJ, M.A., Geothermal revources: potential energy glant, 258

vollint INE, L., Pubile oplinion in cobb

Valley concerning geotheraal

development in Lake County.

California, 50 (LBL-5204)

public oplnion concerning geotheraal
WAGNER, S.C., state taxation of geothermal resources compared with ta te taxation of other energy Inerals, 133

WALLACE, L.T., SEE ANDERSEN, S.0., 140

WALLER, R.L.' SEe TARLOCK A.D., 22

WALLER, R.L.' SE TARLOCK A.D., 22

UANG, C.H., See LOVELAND, W.D., 15
WARREN, C., Cel iforni geothermal resources: how weli are we doing, 124

WAYLAND, R.G., Impacte of energy resources removal from Federal and Ind ian land 282

WEHLAGE, E.F. 1974: the geothermel year in retrospect, 182

Soclal Implications that may arise wth future geothermal use, 125 Soclal laplications may arise with ruture geothermal usage, 93

NEINBERG, A.M., Observations on Federal Energy Research and Development, Decenber 1974, 71

$U . S$. energy $R$ and $D:$ polley and priorities, 294

WEINSTEIN, D., Legal aspects of geothermal energy development, 126 WENDT, M., SE LAERMANN, K.H., 55 HERES, $D$. Se VOLLINTINE, L., 50,65 WHAN, G.A., SEe SANDQUIST, G.M., 380

WHITE, C.R. Water and power from geothermal resources in

Callfornia. An overviow, 313

WHITE, D.E., SEe GODHIN, L.H., 434

WHITNEY, H.H., SEQ GARDNER, R.J. 38

WILLIAMSON, J.K., SEe LETLOH, K., 82

See VANSTON, J.H., 80

WILLIS, E.H., ERDA': geothermal $R$ and D prograe, 102

WILSON, J.S., Analyel so the potential use of geothermal energy for power generation along the Texas Gulf Coast, 150 (NSF-RA-N-$74-246)$

UILSON, S.H., Possible conflict

between the interests or tourlsm and geothermal power development, 127

WINTERS, J.H., EnvI ronmentally sensitive land use regulation in Callfornia, 357

MOLFRAK, E. SE LAERKANN, K.H., 55

UOOD, Bi, Geotherwal power, 374

YATES, P.J., SEe WHITE, C.R., 313 YOUNGQUIST, W., Pacif Ic Northuest geothermal: review and outlook, 61

$\mathbf{z}$

2RAKET, C.A. Briefing on energy pollcy, 385

Energy self-sufficiency: how much: how soon, 216 


\section{SUBJECT INDEX}

The subject Index is based on the use of subject descriptors selected from a controlled thesaurus of terms. Subject descriptors and qualifiers (subheadings) are selected and presented in the following format:

SUBJECT DESCRIPTOR/QUALIF IER

Title, (supplementary information), citation number, (report number)

The title aay be suppleaented with additional words, or a phrase, if it appears additional information would be helpful. In cases for which thetitle contalins little or no information related to the subject entry, it way be replaced entirely by the supplementary information. A qualifier is not always required, and in such cases the titie wil follow the unqualifled subject descriptor. The descriptors selected for use as subject terms are generally the names of speciric materials, things, or processes. To the extent possible, qualifier is selected to describe the properties of, or processses applied to, the subject tern.

Index entries are selected to Indicate the Iaportant Ideas and concepts presented in a document, rather than words that may appear in the text.

Within the avallable thesaurus terms, the most probable or logical place to look for typical information is selected. "See references" are included to guide users from aynonymous teras or phrases to the descriptor selected as subject heading for the concept. (e.g. Pipeline Quality Gas see HIGH BTU GAS). " See also

references"' are used to indicate where to find

references to subject concepts that are narrower, broader, or related to a particular subject heading. To complete an exhaustive search of a given subject, all such headings should be reviewed.

AGRICULTURE

Alternative sources of energy: practical technology and philosophy for a decentralized society, 213

AIR POLLUTION/RESEARCH PROGRAMS

President's message on supply of energy and clean alr, also fact sheet from Office of the White House Press Secretary, 425

air POLlUTion abatemEN T

Geographical environmental analysis. Final report, 29

Geothermal Envi ronmental Advisory Panel. Second annual report, July $1,1975-J u n e ~ 30,1976,136$

Geothermal resources operational (GRO) Order No. 4 for central and western reglons, 168

Geothermal Environmental Advisory Panel. Firat annual report, June $1,1974-J$ une $30,1975,225$

Geothermal Stean Act of 1970. Public Law 91-581, Senate Res. 368, 91st Congress, Decenber 24, 1970, 391 ALASKA/GEOTHERMAL RESOURCES

Geothermal energy: econonic potential of three altes in Al aska (Kobuk, Unalaska, and stikine River sites), 200 ALASKA/GOVERNAENT POLICIES

State pollcles for geothermal development, 85 (NSF/RA760230 )

ALASKA/US ORGAKIZATIONS

A brief outline of geothermal regulatory ageneles in the western United States, 304

ALASKa OIL PIPEL INE/LEGISLATION

Highlights of energy related legislation in the 93rd Congress. Prepared at the request of Henry $M$. Jackson, Chalraan, Comalttee on Interior and Insular Affalrs, United states Senate pursuant to S.Res. 45 , 215

ALCOHOLS

Al ternative sources of energy: practical technology and phllosophy for a decentralized soclety, 213

ARIZONA/ENERGY SOURCES

Financing infrastructure in energy development areas in the West. Proceedings of a conference held Auguat 21 and 22,1975 , in Snowbird, Utah, 218

ARIZONA/GEOTHERMAL RESOURCES

Dinner Session, Thursdey, 10 May 1973 (National

Conference on Geotheral Energy, Palc Springs,

8 INDEX
California), 339

ARIZONA/GOVERNAENT POLICIES

state pollcies for geothermal development, 65 (NSF/RA760230 )

ARIZONA/US ORGANIZATIONS

A brief outline of geothermal regulatory agencies in the western United States, 304

ARIZONA/UATER RESOURCES

Western states water requil rements for energy development to 1990,249 (NP-20555)

ATTITUDES

See PUBLIC OPINION

AUTOMOBI LES/EFFICIENCY

The energy crisis and proposed solutions. Panel

discussions before the Comittee on Ways and Means.

House of Representatives, Ninety-Fourth Congress,

First session on the energy crisis and proposed

solutlons, part 3 of 4,201

AUTOMOBILES/GOVERNMENT POLICIES

The energy crlsis and proposed solutions. Panel discussions before the Committee on Hays and Means. House of Representetives, Ninety-Fourth Congress, First Session on the energy crisis and proposed solutions, part 3 of 4,201

B

BIBLIOGRAPHIES

Geothermal energy. Volume I. 1964-April 1975 (cltations fron the NTIS data base). Report for 1964-Apr 1975, 52 (NTIS/PS-76/0462)

Geotheraal energy. Volume 2. 1975-Aprll 1976 (cltations Irom the Engineering Index data base). Report for 1975-Apr 1976, 53 (NTIS/PS-76/0465)

Geothernal resources: exploration and exploitation. blbl lography, 43 (TID-3354-R1)

Geothermal energy. Volume 2. Search perlod covered: May 1975-April 1976. Citations from the NTIS Data Base, 137

Geothermal energy. Volume 1. Search period covered: 1970-1974. Citations from the Engineering Index Date Base, 138

Geothermal power economics: an annotated bibllography, 278

Power from the Earth: geothermal energy, 411

Sumary and concluding remarks (Legal aspects of geotheranl resource development), 24

BIBLIOGRAPHITES

Ecomonles of geothermal exploration, 312 BIOMASS

(Al1 growing organic matter such as plants, trees, grasses, and algae.)

BIOMASS/USES

Alternate energy sources for Haull. Proceedings of the workshop held May 8-9, 1975, in Honolulu, Hawail, 219

BREEDER REACTORS/ENUIRONMENTAL EFFECTS

U.S. energy $R$ and $D$ : polley and priorities, 294

BRINES/DESALINATION

Sone Interfaces in resource utilization (Geothermal energy, energy transalssion, and desal ination of underground water in New Hexico), 484 (LA-UR-73-570)

BRINES/OWNERSHIP RIGHTS

Salt water is a alneral: ounership of a natural resource of Increasing Importance in oll-producing states, 417

BUDGETS/PUBLIC OPINION

Results of an opinion survey on the 1977 budget proposal of the Energy Research and Development Administration. Printed at the request of Henry $M$. Jackson, Chaf ran, Comittee on Interior and Insular Affalrs, United States Senate, 86

BUDGETS/RESEARCH PROGRAMS

An analysi: Identifying issues in the fIscal year 1976 ERDA budget. Report prepared for the Comalttee on Sclence and Technology, U.S. House of Representatives, Comittee on Interior and Insular Affalrs, U.8. Senate and the Joint Committee on Atonic Energy, MinetyFourth Congress, First sesion, 209 


\section{CALIFORNIA}

SEe I IO IHPERIAL VALLEY

Legal, Institutional, and political problens in producing electric power froa geothermal resources in california 144

CALIFORNIA/ENERGY CONSUMPTION

Californla's energy future, 88

Luncheon session, Thursdey, 10 May 1973 (National Conference on Geotherail Energy, Palm Springs, Calif.) 340

CALIFORNIA/ENERGY DEMAND

Luncheon sesslon, Thuraday, 10 May 1973 (Natlonal con

CALIFORNIA/ENERGY POLICY

California Energy Workahop: developing a plan of action to neet the energy crisis in California, 323 ( $\mathrm{PB}-$ 237045)

Callfornia's energy future, 88

Proposed energy research and development program: flscal year 1976/77. Callfornia Energy Resources Conservation and Devalopment Comalssion, 73 (NP-21008) CALIFORMIA/ENERGY SOURCES

Research, development, and the energy crlsis. Hearings held November 20, 1973, 383

CALIFORNIA/ENERGY SUPPLIES

Calleornla's energy future, 88

Energy alternative for California: poths to the future 147

CALIFORNIA/ENVIRONMENTAL IHPACT STATEKENTS

Admint trative law of Callfornia's resources agencys portion of the directions for preparing environaental Impact reports, 350

CALIFORNIA/GEOTHERMAL. ENERGY

Geotheraal energy In Callfornla: status report, 44 (JPL5040-25(Rev.A) (APp.) )

Geothermal resource development process, 47 (JPL-504025(Rev.A)(App.))

Geothermal energy: legal problems of resource development, 105

Geothermal power expansion in California, 266

Geothermal power In Callfornia, a response to senate Resolution No. 138, relating to the use of geothermal power for the transportation of water over the Techachap Mountains (Research proposels), 468

Preaent plans for ut llization of geotheral energy, 45 (JPL-5040-25(Rev.A) (App.))

Publ te hearing on geothernal energy and assoclated ineral resources, 475

Public opinion concerning geotheraal development in Lake County, Californta, 65 (LBL-4447)

Research and development, 46 (JPL-5040-2S(Rev.A)(App.))

Susanville Geotheraal Energy Project overview, 36 (SAN$1077-4$ )

Susanvill project requi rements, 37 (SAN-1077-4)

Susanville Geotheral Erergy Project. Workshop proceedings linal technical report, 40 (SAN-1077-4)

Susanville Geothermal Utility System, 11 (SAN-1077-4)

CALIFORNIA/GEOTHERMAL EXPLORATION

California's geothermal resources (Legal and

technologleal tatus), 462

Californta laws for the conservation of geothermal energy, an act to amend the heading of Chapter 4, and to add to Chapter 3, Diviaion 3, of the Public Resources Code, relating to geotheral resources, 463

Role of the state Land Division in developing geotheraal resources in California, 70

CALIFORNIA/GEOTHERHAL RESOURCES

Compendiun of rirst day papers presented at the firet Conference of the Geothermal Resources Counc11, El Centro, California, Feb 1972, 412

Dinner Session, Thursday, 10 Kay 1973 (National Conference on Geothermal Energy, Pale Springs, California), 339

Energy alternatives for Calliornia: paths to the suture 147

Geothermal Leasing Prograx. Volume I. Promulgation of leasing and operating regulations. Final onvironmental impact tatement, 326 (EIS-CA-73-1681-F1)

Geothermal Leasing Program. Volume II. Leasing of geothermal resources in three California areas. Final envi ronmental inpact statement (Clear Lake, Mono lake, Imperial Val ley). 327 (EIS-CA-73-1681-F-2)

Geothermal Leasing Program. Volume III. Appendices A through H. Proposed geothermal, leasing, and operating regulations. Final environmental impact st at ement, 328 (EIS-CA-73-1681-F-3)

Geothermal Leasing Progran. Volume IV. Appendix I. Comments on draft impact statement and proposed regulationa. Final environmental iapact statement. 329 (EIS-CA-73-1681-F-4)

Geothermal energy in Celifornia: status report, 44 (JPL5040-25(Rev.A) (APP.)

Geothermal resources in Callfornfa (32,000 wW power capacity (1970), 408

Geothermal resources in Callfornta-potential s and problens, 418

Geothermal resources in Callfornia, 470
Hearing on the ownership of geothermal tean underlying Geysers. Geothermal Kinetics Inc., platntiff, va Union ofl Company of Callfornia, defendants, May 28, 1976,33

Interdisclplinary planning for geotheral development at the county level, 99

Role of the state Lands Division in developing geothermal resources in California, 70

Water and power from geothermal resources in Californlo. An overview, 313

CALIFORNIA/GEOTHERMAL WELLS

Selected portions of Callfornis state-ulde geotheraal regulations. Appendi $x$ B, 305

CALIFORNIA/GOVERNMENT POLICIES

State policles. For geothermal development, 85 (NSF/RA$760230)$

CALIFORNIA/LAKD LEASTNG

Callfornia laws for the conservation of geotheral energy. an ect to amend the heading of Chapter 4, and to add to Chapter 3, Division 3, of the Public Resources Code, relating to geothermal resources, 463

Geothermal Leasing Progran. Volume II. Leasing of geothermal resources in three Californla areas. Final environmental Impact tatement (Clear Lake, Mono lake, Inperial Valley), 327 (EIS-CA-73-1681-F-2)

Geothermal leasing program, considers impact of leasing and operating regulations to Iaplement the Geotheral stean Act of 1970 and leasing of 3 areas in Callfornia. Draft environmental impact atatement, 421 (PB-203102-D) CALIFORNIA/LAND USE

Environaentally ensitive land use regulation in Calleornia, 357

CALIFORNIA/LEGISLATION

Callfornia's geothermal lands: a legal franework for resource development, 121

Callfornia geothermal resources: how well are we dolng, 124

California public resources code: statutes pertaining to geothermal resources, 348

Callfornta laws for the conservation of geothermal energy (Chapter 1483, statutes or 1965), an act to add Chapter 4, Division 3, to the Public Resources Code, relating to geothermal energy and assoclated resources. relit

Geothermal power in Californla, a response to Senate. Resolution No. 138, relating to the use of geothereal power for the transportation of water over the Techachap Mountains (Research proposal s), 468 Public and geology-related legislation In California. 1968-1972,381

Role of the state Lands Divialon in developing geothermal resources in Callfornia, 70

CALIFORNIA/MINERAL RESOURCES

Public hearing on geothermal energy and assoctated aineral resources, 475

CALIFORNIA/PUBLIC LANDS

Administrative laws of Calffornia's state Lend Commlsion: regulations pertaining to geotherad resources, 349

Calffornia public resources code: statutes pertaining to peotheral resources, 348

CALIFORNIA/PUBLIC OPINION

Public opinion concerning geothermal development in Lake County, Cajl fornia, 65 (LBL-4447)

Public opinion in Cobb Valley concerning geothermal development in Lake County, Calitornia, 50 (LBL-5204)

CALIFORNIA/PUBLIC UTILITIES

Californla public utilitles comalission., 146

Role of municipalities In geothermal resource developaent, 14

CALIFORNIA/REGULATIONS

Adminf strative laws of California's state Land Comission; regulations pertalning to geothermal resources, 349

Adminlatrative law of California's resources agency: portion of the directions ror preparing environmental impact reports, 350

Role of state government in the development of geothermal resource, 369

Selected portions of Californle state-wide geothermal regulations. Appendix $B, 305$

Terms, conditlons, standards, and application procedures for InItial geothermal development: Imperial County, Callfornia, 351

CALIFORNIA/RESEARCH PROGRAMS

Proposed energy research and development progras: flscal year 1976/77. California Energy Resources Conservation and Development Commission, 73 (NP-21008)

\section{CALIFORNIA/TAXE}

1977 guidebook to California taxes with special emphasis on relationshlp to Federal taxes, 25

State taxation of geothermal resources compared with state taxation of other energy minerals, 133

CALIFORNIA/US ORGANIZATIONS

A brief outline of geothermal regulatory agencies in the weatern Unlted States, 304

CALIFORMIA/WATER RESOURCE

Interstate environmental problems: a gulde to water pollution and water scarcl ty, 317

ater and power from geothermal resources in Californis a. An overview, 313

Water supply: economics, technology, and policy (Book), 


\section{5}

Western states water requirements for energy development to $1990,249(N P-20555)$

CALIFORNIA/UELL DRILLING

selected portlons of Callfornla state-ulde geothereal regulations. Appendix B, 305

CANADA/ENERGY SOURCES

Continuing energy crisis in America, 210

CASE LAU

Acquisition of geothermal rights: proposed methods, 478

Environmentally sensitive land use regulation in Callfornia, 357

Geothermal resources: water and other conflicts encountered by the developer. An alternative energy source which is "gathering stean"", 15

Geothermal tax considerations and sheiters, 229

Geothermal resources operati onal Order No. 4: general envi ronmental protection requirements, 237

Interatate environmental probiens: guide to water pollution and water ecarclty, 317

Refch. Arthur E. and Carolyn C. Reich va Coanssion of Internal Revenue, U.S. Tax Court, July $31,1969,456$

Salt water is a meral: ownership of a natural resource of increasing importance in oll-producing states, 417

Tax treatment of exploring and developing geothermal resources, 336

Victory Sand and Concrete, Inc, vs Conal saloner of Internal Revenue, January 2, 1974, 319

CHILE/RECREATIONAL AREAS

Possible conflict between the interests of tourlan and COAL.

\section{See 1 so COAL GASIFICATION
COAL LIQUEFACTION}

Continuing energy crisis In America, 210

Natural resources development and pollcies, including environmental consIderatlons, 437

COAL ENERGY POLICY

Energy in soclety (Horldulde polley distribution and development), 370

COAL/GOVERMAENT POLICIES

Mining and ineral policy: 1976 bicentennial edition, 42 (NP-21355)

COAL GASIFICATION

Proceedings of cltizens' forue on potential future energy sources held at Portland, Oregon, January 17, 1974,223

COAL GASIFICAT.ION/RESEARCH PROGRAMS

S.1283, National Energy Research and Development Pollcy Act of 1973,359

COAL INDUSTRY/PLANNING

Indians cautlous on development, 32

COAL LIQUEFACT ION

Proceedings of citizens forum on potentlal future energy sources held at Portlend, Oregon, January 17, 1974,223

COAL LIQUEFACTION/RESEARCH PRQGRAKS

5.1283, National Energy Research and Development Pollicy Act of 1973,359

COAL MINING/ENVIRONMENTAL IMPACTS

Inpacts of energy resources removal from Federal and Indian lands, 282

COLORADQ/ENERGY POLICY

Energy technology update for Colorado deciston makers. Proceedings of a conference held March 5, 1975, in Golden, Colorado, 220

COLORADO/ENERGY SOURCES

Energy technology update for Colorado decision aakers. Proceedings of a conference held March 5, 1975, in Golden, Colorado, 220

Financing infrastructure in energy development areas in the West. Procesdings of a conference held August 21 and 22,1975 , In Snowbird, Utah, 218

COLORADO/GEOTHERMAL RESOURCES

Recent geothermal developients in Colorado, 174

Rules and regulationa relating to geotheral leases on Colorado sta te ouned lands, 292

COLORADO/GOVERNMENT POLICIES

State polleles for geothermal development, 85 (NSF/RA760230)

COLORADO/US ORGANIZATIONS

$A$ brlef outline of geothermal regulatory agencies in the western United States, 304

COLORADO/WATER RESOURCES

Western states water requlrements for energy development to 1990,249 (NP-20555)

COMMERCIALIZAT ION

See 1 so DEMONSTRATION PROGRAMS

ECONOKIC DEVELOPMENT TECHNOLOGY TRANSFER

ERDA's geothermal $R$ and D program, 102

Geothermal energy research, development, demonat ration, and production; Federal guarantees on loans, 58

Legal and institutional factors. Geothermal research study In the Salton Sea region of California, 233 COMMUNITIES/ECONORICS

Financing infrastructure In energy development areas in the West. Proceeding of a conference held August 21 and 22, 1975, in Snowblrd, Utah, 218

COMMUNITIES/GEOTHERMAL ENERGY

Characteristics of nine comaunities considering geothermal utilization, 39 (\$AN-1077-4)

COMWUNITIES/INUESTMENT

Boom towns may hinder energy resource development (Rocky Hounteln West), 72

Community planning, 264 (JPL-5040-6(Vol-3))

COMMUNITIES/SOCIAL SERVICES

Boom touns may hinder energy resource developeent (Rocky Mountain Uest), 72

COMNUNITIES/SOCIO-ECONOKIC FACTORS

Community planning, 164 (JPL-5040-6(Vol.3))

CONFERENCES

SES MEETINGS

CONSERVATION (RESOURCE)

SE RESOURCE CONSERUATION

CONTRACTS

Geothermal resources folnt ventures, 13

Geothermal sales contracts, 21

Role of municipalities in geothermal resource development, 14

CRUDE OIL

$$
\text { SE PETROLEUM }
$$

CULTURAL RESOURCES

Geothermal resources operational Order No. 4: general environmental protection requi rements, 237

DEMONSTRATION PROGRAMS

Se* 1 :0 COMMERCIALIZATION

DEMONSTRATION PROGRAMS/RECOMMENDAT IONS

Legal and Institutional factors. Geothermal research study in the Salton Sea reglon of Callfornia, 233 DEPLETION ALLOWANCES

Economica of the common pool: property rights in exhaustible resources, 439

Energy taxes and subsidies, 314

Geothernal tax considerations and sheiters, 229

Geothermal exploration and developaent in the United States: tax analysis under the Internal Revenue Code, 230

Income taxation of geothermal resources, 20

Internal Revenue Service Regulations (Mineral depletion allowances for tax purposes), 458

Relch, Arthur E. and Carolyn C. Relch ys Conmlssion of Internal Revenue, U.S. Tax Court, July 31, 1969 (Depletion al lowances for intangible costs of drilling and developing geotheraal team wells), 456

DEPLETION ALLOHANCES/CASE LAW

Victory. Sand and Concrete, Inc. va Comalssioner of Internal Revenue, January 2, 1974 (Mineral depletion alloweses for and and gravel under public land leases, 26CFR611(a); 26CFR613), 319

DEPLETION ALLOWANCES/CASE LAUS

Relch, A.E. t al. vs Comml seloner of Internal Revenue and G.D. Rowan et al. vs Commlssioner of Internal Revenue. U.S. Court of Appeals, Ninth Circuit. January 21, 1972 (Judicial interpretetion of IRS tax regulations relative to depletion allowance for geothermal well drilling and development; 26 CFR 1. $263(\mathrm{c}), 1.611(\mathrm{a})$, and $1.613(\mathrm{~b})), 416$

DEPLETION ALLOWANCES/LEGAL ASPECTS

hajority opinion in the Relch case: question of deplet I on, 352

DEPLETION ALLOWANCES/TAXES

Relch case: conomic Implications of depletion allowances, 222

DIRECTORIES

Geothermal world directory, 89

EAST RESA GEDTHERMAL FIELD See al 1 OO IMPERIAL VALLEY

EAST MESA GEOTHERMAL FIELD/LAND USE

Effects of geothermal development on the egricultural resources of the Imperial Valley, 6

ECONOMIC DEVELOPWENT

See 1 so COMMERCIALIZATION

Mult I-purpose geothermal resource development: an overview, 91

ECONONIC IMPACT

See al so SOCIO-ECONOMIC FACTORS

Economic Impact of geothermal energy developnent, 5

Federal role in geothermal resource developaent, 18

Multisector analysis of the impact of geothermal development on the economy of Imperial County, California, 28

Population analysis relative to geotheraal energy development, Imperlal County, Californla, 8

ECONOMIC POLICY

Continuing energy crisis in Amerlca, 210

ECONOHICS

1977 guidebook to Callfornia taxes with speclal emphasis on relationship to Federal taxes, 25

A technology assessment of geothermal energy resource development, 184 (PB-246241)

Afternoon General Session, Friday, 11 Hay 1973, 341

Analysis of the potential use of geotheraal energy for power generation along the Texas Gulf coast, 150 (NSF- 
$R A-N-74-246)$

Assessment of geothermal energy resources, 393

Briefing on energy pollcy, 385

Cellfornia public utllities conmiselon., 146

Characteristics or nine communities considering geotherwal utilization, 39 (SAN-1077-4)

Continuing energy crisis in Americe, 210

Costs of geothermal energy development. Final report, January 1977,3

Decision statement of Secretary of Interior on geothermal resources program, 267

Development of the Nation' geothermal energy resources. II, 154

Earth's heat tapped for geothermal power development, 420

Ecomomics of geothermal exploration, 312

Economic and englneering implications of the Project Independence 1985 geothermal energy output goal and the assoclated seneitivity analysis, 96

Economlc and soclal apecta of geothernal energy resource development, 128

Economlca of the comon pool: property rights in exheustible resources, 439

Economica of geothermal power in the United States, 449

Economics of exhaustible resources. I. The peculiar problems of ineral wealth, 482

EIR's: truth and consequences, 306

Electrie utfilties, 163 (JPL-5040-6(Vol.3))

Energy alternatives: a comparative analysis, 214

Energy and the future, 362

Energy company: monopoly trend in the energy markets, 430 ( PB-218830)

Energy crisis and the consumer states, 332

Energy economl $\mathrm{cs}, 66$

Energy in cociety, 370

Energy outlook for the $1980^{\prime} \mathrm{s}$. A atudy prepared for the use of the Subcommittee on Economic Progress of the Joint Economic Comittee, Ninety-Third Congress, FIrst Session, by H. N. Peach, Decenber 17, 1973, 388 Energy politica of France, 78

Energy policy interactions in the United States, 333

Energy regulation by the Federal Power Comal esion, 316

Energy research and development. Ninety-Third Congress First Session, Decenber 1, 1973, 387

Energy self-sufficiency: how much; how soon. 216

Energy taxes and substales, 314

Environental Inpacts of geotheraal resource development on comercial agriculture: cese study of land use conflict, 131

Environmental aspects of nuclear otiaulation, 380

FEA: prices hold key to energy future, 63

Federal energy/environmental research and development program, 212

Federal tax polley and geothermal energy development, 331

Finencing infrastructure in energy development a reas in the Hest. Proceedings of a conference held August 21 and 22,1975 , in Snowbird, Utah, 218

Financing infrastructure in energy development a reas in the Hest. Proceedinga of a conference held August 21 and 22, 1975, in Snowbird, Utah, 218

Formation, funding, and development of a inall exploration company, 231

Geothermal resource characterlstica, exploration considerations, and property acquisition techniques, 270 (CONF-741145-3)

Geothermal energy: Cconomic potentlal of three st tes in Alaska, 200

Geothermal resources, present and future demand for power and legielation in the state of Hyoming. Public information oeries 1,67 (NP-21229)

Geothermal resources: exploration and exploftation. bibllography, 43 (IID-3354-R1)

Geothermal energy as an 'alternati ve' source, 54

Geothertial energy research, development, demonst ration, and production; Federal guarantes on loans, 58 Geothernal energy, 94

Geothernal energy, 94 it uses: technical, economic envi ronmental, and legal apecte, 110

Geotheraal exploration and development In the United states: tex enalysis under the internel revenue code, 117

Geothermel energy. Volume 2. Search perlod covered May 1975-April 1976. Citations from the NIIS Data Base, 137

Geothermal energy. Volume 1 . Search period covered: 1970-1974. Citations from the Englneering Index Data Base, 138

Geothernal energy: the challenges that lle ahead (Part 2 of two-part ert(1ele), 193

Geothermal resources research and technology, 245

Geothermal Energy Resesceh, Development, and Demonstration Act of 1974. Submltted by Mr. Teague, Comittee on selence and Astroniutics, to the House of Representetives, Minety-Third Congress, Second Bession, 274

Geotheral power econoulcs: an annoteted bibllography, 278

Gethernal resources research, 375

Geothermal energy. Hearings before the subcomittee on energy of the Coand tee on science ind hstronautics, United stetes House of Representetlves, Ninety-Third Congress, First session on H.R. 8626, H.R. 9658,

September 12, 13 , and $18,1973,379$

Geothernal resources researeh, 394

Geothermal world directory, 401
Geothermal resources, present and future denand for power, and legislation in the tate of Wyoming, 410 Geotheral resources in'Callfornla-potentials and problems, 418

Geothermal energy, its future and econonics, 419

Geotheral resources in Californit, 470

Impacts of energy resources removal from federal and Indian lands, 282

Institutional, business, and financlal aspects of the geotheral energy Industry, 252

Introduction: the energy out look, 377

Legal probleas of the geothermal industry. 469

Montana energy polley tudy, 202

Mult1-purpose geothermal resource development: an overview, 91

Multipurpose geothermal resource development: an overview, 114

Nation's energy future. A report to Richard M. Nixon, President of the United States, 322 (UASH-1281)

National progran definition study for the non-electrical utilization of geothermal energy, 173 (ANCR-1214)

Other energy sources, 64 (CDNF-760205-)

Potential national benefits of geotherwal electrical energy production from hydrothermal resources in the West, 97

Prelininary report on legal and public policy setting for geothermal resource development in Hawall, 279

Profect Independence report, 287

Project Independence Blueprint: final task force report. Geothermal energy, 288

Public opinion concerning geothermal developaent in Lake County, Calltornia, 65 (LBL-4447)

Public pollcy toward environment 1973: a review and appraisal. Nuclear and other energy, 358

Relch case: economlc Iaplications of depletion allowances, 222

Research and devol opment, 46 (JPL-5040-25(Rev.A)(App.))

Review of Project Independence Blueprint panel

subconittee reports on FEA-Interagency task forces.

Report on CTAB recomaendations for nationol energy

progran... Subcomittee working documents, 198 (COH-7510500 )

Socio-econonic model, 38 (SAN-1077-4)

Solar and geothermal energy: new competition for the aton, 248

sone interfaces in resource ut111zation, 484 (LA-UR-73570)

staff report to the Federal Trade Commision on Pederal energy land policy: efficlency, revenue, and competition, 152 (PB-246663)

state polleles for geothermal development, 85 (NSF/RA760230 )

status of economics and IInancing geothermal energy power production, 227

structure of the geothereal Induatry through 1974, 238

Studies in energy tax pollcy, 208

summary of section $X I$ : economic and rinancial aspecte, 108

Susanville Geotheraal Energy Project overview, 36 (SAN1077-4)

Susanyl11. project requirements, 37 (SAN-1077-4)

Tax treatment of exploring and developing geothermal resources, 334

The energy crisil and proposed solutions. Panel discusslons before the Connittes on Hays and Heans. House of Representatives, NInety-Fourth Congress, First session on the energy crisis and proposed colutions, part 3 of 4,201

The potential for energy production from geothermal resources: Report of the Subcommittee on Water and Pover Resources, Comblttes on Interior and Insular Affairs. United States Senate, Ninety-Third Congres, First session, 324

Toward national policy on energy resources and mineral plant loods. (Special publication), 361 (PB-230248)

Toward a natlonal energy polley, 356

Unitization for geothermal resources: united we save, 17

Utility participetion In geothermal energy source, 293

vietory Sand and Concrete, Inc.-va Conglssioner of Internal Revenue, January $2,1974,319$

Vater eupply: economics, technology, and polley, 455

wtnesses for ofl: the case agalnst dismemberment, 130 ELECTRIC POWER See 1 :o HYDROELECTRIC POWER

ELECTRIC POHER/DEHAND FACTORS

Electric power, fuels development, and protection of the environment: legielation introduced in the 91 at Congrese, 453

ELECTRIC POWER/LEGISLATION

Leglslative goals of electric companles in 1974, 264 ELECTRIC POWER/REgULATIONS

Energy regulation by the Federal Power Commission, 316 ELECTRIC POUER/RESEARCH PROGRAKS

$R$ and $D$ in generation: giving prectical direction to diverse views, 145

ELECTRIC UTILITIES

Soe PUBLIC UTILITIES

ENERGY

See 1 so GEOTHERMAL ENERGY NUCLEAR ENERGY

ENERGY/BUDGETS SOLAR ENERGY 
EXOP report on federal energy $R$ and $D$ funding, 415 ENERGY/ENUIRONMENTAL EFFECTS

Energy: the new era (Book), 273

ENERGY/GOUERNAENT POLICIES

U.S. energy $R$ and D: pollcy and prloritles, 294 ENERGY/LEGISLATION

Energy legislation. Report of the Subcomittee on Energy of the Comittee on Science and Astroneutics, U,S - House of Representatives, Ninety-Third Congress, second session, 277

Highlights of energy related legislation in the 93rd Congress. Prepared at the request of Henry $M$. Jackson, Chairman, Committee on Interior and Insular Affafrs, United States Senate pursuant to S.Res. 45 , 215

U.S. energy $R$ and $D$ : policy and prioritles, 294 ENERGY/REGULAT IONS

Federal energy regulation: an organizational study, 262 (TID-26559)

ENERGY/RESEARCH PROGRAMS

An analysis Identifying lssues in the flscal year 1976 ERDA budget. Report prepared for the Comittee on Science and Technology, U.S. House of Representatives, Committee on Interior and Insuler Afrairs, U.S. Senate and the Jolnt Comittee on Atomlc Energy, NinetyFourth Congress, First session, 209

Authorlzing appropriatlons for the Energy Research and Development Adsinistration. Conference report to accompany H.R. 3474, 206

Energy research polley alternatives. Hearing pursuant to S. Res. 45, a national fuels and energy poll $1 \mathrm{cy}$ study, on existing federal energy research and development pollcies and future technologlcal options, U. S. Senate, June $7,1972,403$

EXOP report on federal energy $R$ and $D$ funding, 415 Federal organization for nonnuclear energy research and development activities of departments and agencies other than ERDA: FY 1976, 175 (NP-20699)

Highlights of energy related leglalation in the 93rd Congress. Prepared at the request of Henry M. Jackson, Chalrman, Compittee on Interior and Insular Afrairs, United states senate pursuant to S.Res. 45, 215

Proceedings of the energy research priorlties conference held at Berulck Academy, South Berwlck, Maine, July $30-$ August $4,1972,483$ (CONF-720742-)

Research, development, and the energy crisis. Hearing before the Subcomittee on Energy of the Committee on Sclence and Astronautics, U.S. House of Representatives, Ninety-Third Congress, First session, November 20, 1973, 272

Research, development, and the energy crisis. Hearings held November $20,1973,383$

U.S. energy R. and D: poiley and prioritles, 294

ENERGY/SYSTEKS ANALYSIS

Energy alternatives: a comparative analysis, 214 CNERGY BALANCE

Comparative analysis of the 1976 ERDA plan and program, 95

ENERGY CONSERVATION

Afternoon General Session, Friday, 11 May 1973, 341

Al ternative energy sources for the UK, 77

Al ternative sources of energy: practical technology and philosophy for a decentralized society, 213

An analysis identifying Issues in the fiscal year 1976 ERDA budget, 191 (PB-244863)

An analysis of the ERDA plan and progran, 153 (PB-250636)

An analys Is Ident Ifying lssues in the $P 1$ scal year 1976

ERDA budget. Report prepared for the Comittee on

Science and Technology, U.S. House of Representatlves, Comittee on Interior and Insular Affairs, U.S. Senate and the Joint Committee on Atonic Energy, NinetyFourth Congress, First seasion, 209

Analysis of the ERDA plan and program, 205

Authorizing appropriations for the Energy Research and Development Adminiatration. Conference report to accompany H.R. 13350,106

Authorizing appropriations for the Energy Research and Development Administration. Conference report to accompany H.R. 3474,206

Callfornia's energy future, 88

Continuing energy crisis in Americe, 210

Energy: 1975. The first annual report of the lowa

Energy Poliey Councll, 194 (NP-20667)

Energy: the new era (Book), 273

Energy alternatlves: a comparative analysis, 214

Energy and the ruture, 362

Energy and materials, 384

Energy cholces and public policy, 158

Energy crisia: revision in U.S. policy to preserve national security, 330 ( $A D-778886)$

Energy in Oklahowa. Volume one. Final report of Ok l ahoua Energy Advi sory Councll, February 1, 1974, 276

Energy in Texas. Volume II. Policy al ternatives, 281

Energy legislation. Report of the Subcomittee on Energy of the Committeo on Selence and Astronautics, U.S - House of Representatives, Ninety-Third Congress, Second Session, 277

Energy self-suffictency: how wuch; how soon, 216

Energy technology update for Colorado decial on makera. Proceedings of conference held March 5, 1975, in Golden, Colorado, 220
ERDA authorlzation, Flscal Year 1977. Part IV. Basic energy sciences. Hearings before the Subcomittee on Energy Research, Development and Denonstration of the Committee on Science and Technology, U.S. House of Representatives, Ninety-Fourth Congress, Second Session, February 26, 1976,129

Federal energy/environmental research and development progran, 212

Montana energy pollcy, study, 202

Nation's energy Iuture. A report to Rlchard $M$. Nixon, President of the United States, 322 (HASH-1281)

National plan for energy research, development and demonstration: creating energy cholces for the future. Volume 2. Program implementation, 84 (ERDA-76-1(Vol.2)

Nonnuclear energy research and devil 4 (ERDA-76-1(Vol.2) 1976 authorization. Hearings before the Subcomittee on Energy Research and Water Resources of the Comittee on Interior and Insular Affairs, United states Senate, Ninety-Fourth Congress, First Session on S. 598, 204

President's message on energy, 1973, 373

President's message on supply of energy and clean afr, also fact sheet from office of the white House Press Secretary, 425

Presidential energy statements. Printed at the request of Henry M. Jackson, Chafrman, Comittee on Interior and Insular Affalra, United States Senate, NinetyThird Congress, First Session, pursuant to S. Res. 45, a national fuels and energy policy study, 364

Proceedings of the energy research priorities conference held at Berwlck Acadeny, South Berulck, Maine, July 30August 4, 1972, 483 (CONF-720742-)

Project Independence. A proposed program for U.S. energy self-sufficiency by 1980,275

Project Independence report, 287

Proposed energy research and development progran: flscal year 1976/77. Callfornia Energy Resources Conservation and Development Conmission, 73 (NP-21008)

Research, development, and the energy crisis. Hearing before the Subcomittee on Eneray of the Comalttee on Sclence and Astronautics, U.S. House of Representatives, Ninety-Third Congress, First sesion, Novewber $20,1973,272$

Results of an opinion survey on the 1977 budget proposal of the Energy Research and Development Adminlatration. Printed at the request of Henry M. Jackson, Chalrman, Comittes on Interior and Insular Affalrs, Unfted States Senate, 86

Review of Project Independence Blueprint panel subcomit tee reports on FEA-interageney task forces. Report on CTAB recommendations for a national energy program. Subcomittee working documents, 198 (COis-7510500 )

Review of the Project Independence report submitted to Office of Energy Research and Development, National Selence Foundation, January $10,1975,195$ (PB-238791) Self-sufficiency in energy (United Kingdon), 176 State reaponses to the energy crisis, 301

Toward a national policy on energy resources and wineral plant foods. (special publication), 361 (PB-230248) Towards a responsible energy pollcy, 197

ENERGY CONSERVATION/GOVERNKENT POLICIES

Comparative analysis of the 1976 ERDA plan and progran,

Highlights of energy related leglsiation in the 93rd Congress. Prepared at the request of Henry $M$. Jackson, Chal raan, Committee on Interior and Insular Afrairs, United states Senate pursuant to S.Res. 45, 215

The energy crisis and proposed solutions. Panel discussions before the Connittee on Ways and Heens House of Representatives, Ninety-Fourth Congress. First Session on the energy crisia and proposed solutions, part 3 or 4,201

ENERGY CONSERUATION/RESEARCH PROGRAMS

Comparative analysis of the 1976 ERDA plan and progran,

Federal organlzation for nonnuclear energy research and developent activitles of departments and agencies other than ERDA: FY 1976, 175 (NP-20699)

ENERGY CONSUMPTION

Energy. Volume I. Denands, resources, impact, technology, and poltey (Book; compilation of lecture notes), 295

Energy crisis and the consumer states, 332

ENERGY CONSUMPTION/ENERGY POLICY

Natural resources development and policles, Including envil ronmental considerations. Note by the secretaryGeneral: Addendum, changing patterns in the Horld energy ituat Ion, 438

ENERGY CONSUMPTION/ENVIRONMENTAL EFFECTS

Natural resources development and pollcles, Including environmental considerations, 437

Natural resources development and pollcies, including environmental considerations. Note by the SecreteryGeneral: Addendum, changing patterns in the World energy ol tuation, 438

ENERGY CONUERSION/ENUIRONMENTAL EFFECTS

Protecting the environment (Chapter in Encyclopedie of Energy ), 101

ENERGY CONVERSION/PLANNING

Longer-range technologlcal potentiel sor energy development: an assessment of the prospects in nev energy technology, 405 
ENERGY DEMAND

Energy. Volume I. Deands, resources, impact, technology, and policy (Book: compilation of lecture notes), 295

ENERGY DEMAND/FORECAST ING

Hontana energy pol ICy etudy, 202

ENERGY POLICY

1977 guidebook to California taxes with special emphasis on relationship to Federal taxes, 25

A technology assessment of geotherwal energy resource development, 184 ( PB-246241)

Adwinletratlon's enercy wessage and program: the need for prompt development of national energy polley, 406 Afternoon General session. Friday, 11 May 1973, 341

Al ternative sources of energy: practical technology and philosophy for a decentralized soclety, 213

Amerlca's energy potential: aumary and explanation prepared by Congressman Morris $K$. Udall, Chafraan, Subcomittee on the Environment for Use of the Comittee on Interlor and Insular Arfairs of the U.S. House of Representetives. Ninety-thlrd Congress, First Seselon, Detober 1973, 386

An analysis Identifyling issues in the fiscal year 1976 ERDA budget, 191 (PB-244863)

Analysis of the ERDA plan and program, 205

Benefits of atimulating geothermal energy development with tax and research subsidies, 143

Briefing on energy polfcy, 385

California Energy Workshop: developing a plan of action to meet the energy crisis in California, 323 (PB237045)

Comparative analyals of the 1976 ERDA plan and progran 95

Constralnt: on geothermal development: tax and beyond, 19

Continuing energy crisis In Americe, 210

Critical national cholce: new energy horlzons....or horizontal disintegration, 104

Development of geotheraal energy in the Gulf Coast: soclo-econoaic, denographic, and polltical considerat lons, 82 (CONF-760222-P5)

Dinner Sesston, Thursday, 10 Way 1973,339

Electric power, euel development, and protection of the environaent: legislation Introduced in the 91 st Congress, 451

Energy. Volume I. Demands, resources, Impact, technology, and polley (Book; compliation of lecture notes), 295

Energy: 1975. The first annual report of the lowe Energy Pollcy Council, 194 (NP-2 0667)

Energy onalysis and pubilic policy, 155

Energy and materials, 384

Energy crisis and the consumer states, 332

Energy developent and land use In Texas. Final report on Project E/S-1: impact on land use and value of al ternative strategies for production, distribution, and utilization of energy in Texas in the period 19742000,211

Energy economles, 56

Energy in Oklahoma. Volume one. Final report of Oki home Energy Advisory Council, February 1, 1974, 276

Energy legislation. Report of the Subcomittee on Energy of the Comittee on Science and Astronatics, U.S - House of Representatives. Ninety-Thlrd Congress, second sestion, 277

Energy polltics of France, 78

Energy polleles of the world: Venezuela, 221

Energy policy interactions in the United States, 333

Energy regulation by the Federal Power Commission, 316

Energy research and development. Ninety-Third Congrass, First Seesion, December 1, 1973, 387

Energy research pollcy alternatives. Hearing pursuant to $S$. Res. 45, natlonal fuel and onergy pollcy study, on existing rederal energy research and development policies and ruture technological options, development pollcies and ruture

Energy elf-sufficlency: how auch; how soon, 216

Energy bystems. I, 260

Energy taxes and subildies, 314

Englneering wanpower and energy needs. IV. Federal policles have an iepact, 149

Environmental Iapact statement for the Geothermal Leasing Progray, 392

Ex-Assistant Admlnilatrator looks back on ERDA's 1 st year. -and ahead to 2 nd, 60

FEA: prices hold key to energy future (New national energy outlook), 63

Federai energy regulation: an organizational atudy, 262 (TID-26559)

Federal role in geothermal resource development, 18

Geothermal energy resource utlilization program planning, 66 (MTR-7137)

Geothermal energy as an 'alternative' source, 54

Geothermal development policy for an lsolated state the case of Hawali, 119

Geothermal energy exploration, research, and development. Report of the Committee on Interior and Insular Afrairs, United States Senate, Ninety-Third Congress, Second Sestion to accompany S. 2465,280

Gethernal Eneray Research. Developnent, and Conmerciel Demonstrat ion Act of 1973; Geothermal Energy Research, Development, and Demonstration Act of 1974. Hearings before the Subcomanitte on Energy of the Committee on Sclence and Astronautics, U.S. House of
Representatives, Minety-ThIrd Congress, Second session on H.R.11212 and H.R.14172, 300

Geotheraal energy. Hearlngs before the abconalttee on energy of the Conmittee on Science and Astronautics. United states House of Representatives, Ninety-Third Congress, First session on H.R. B628, H.R. 9658, September 11, 13, and $18,1973,379$

Geothermal steam Act of 1970. Public Law 91-581, Senate Res. 368, 91 st Congress, December 24, 1970, 391 Geothermal energy resources and research. Hearings pursuant to $\mathrm{s}$. Res. 45, a natlonal fuels and energy policy tudy, on the role of geothermal energy resources in our Nation's euture energy econony, June 15 and $22 ; 1972,402$

Geothermal energy resources and research. Hearlings before the Committee on Interior and Insular Affairs United states Senate, pursuant to $\mathrm{S}$. Res. 45, a natlonal fuel: and energy pollcy tudy, Ninety-Second Congress, Second Session on the role of geotheral 1 energy resources in our nation's future energy econony, June 15 and $22,1972,407$

Hawail geothermal project, 192

Highilghts of energy related leglalation in the 93rd Congress. Prepared at the request of Henry $M$. Jackson, Chal rman, Comittee on Interior and Ineula APralrs, United states Senate pursuant to 5. Res. 45 215

Imperial Valley environmental project, 59 (UCRL-52000-76-

Indians cautious on developaent, 32

Inatitutional barriers to geothermal energy developent. Second report of the Institutional Barrier Panel to the Geothermal Advisory Councll, 234

legal, Inatitutional, and political problens in producing electric power from geothermal resources in California, 144

Legal and policy aspects of geothermal resource development, 398

Leglslative goals or electric companies in 1974, 264

Luncheon Session, Thursday, 10 May 1973, 340

Montane energy polley tudy, 202

Nation's energy future. A report to Richard $M . N i x o n$, President of the United States, 322 (UASH-1281)

National plan for energy research, development and demonstration: creating energy cholces for the future. Volume 2. Program inplenentation, 84 (ERDA-76-1( Vol.2)

Natural resources development and pollcies, Including onvi ronmental consideratlons, 437

Natural resources development and pollcies, including environmental conslderations. Note by the SecretaryGeneral: Addendur, changing patterns in the World energy ituation, 438

Nonnuclear energy reseerch and development: flscal year 1976 athorization. Hearings before the Subcomaittee on Energy Research and Hater Resources of the on Energy Research and Water Resources of the states Senate, Ninety-Fourth Congress, First Session on $5.598,204$

Other energy sources, 64 (CONF-760205-)

Perspective for the 94 th Congress, 311

Power from the Earth: geothermal energy, 41

President's message on energy, 1973, 373

President' messege on upply of energy and clean air. al so ract sheet from orfice of the white House Press Secretary, 425

Presidential energy statements. Printed at the request of Henry M. Jackson, Chalran, Committee on Interlor and Insular Arfairs, United States Senate, NinetyThird Congress, First Session, pursuant to $S$. Res. 45, - national fuels and energy policy study, 364

Proceedings of the energy research prioritles conference held t Berulck Academy, South Berwick, Maine, July 30August 4, 1972, 483 (CONF-720742-)

Proceedings of second geopressured geothermal energy conference, Austin, Texas, February 23-25, 1976. Volume $v$. Legal, Insti tutional, and environmental, 80 ( CONF-760222-P5)

Project Independence. A proposed program for U.S. energy self-sufficiency by 2980,275

Project Independence report, 287

Project Independence Blueprint: final task force report. Geothermal energy. 288

Project Independence Blueprint: transcript of seventh public hearing, Houston, Texas, September 16-20, 1974, 298

Proposed energy research and development progran: fiscal year 1976/77. Callfornla Energy Resources Conservation and Development Commission, 73 (NP-2100B)

Protecting the environment (Chapter In Encyclopedia of Energy ), 201

$R$ and $D$ in generation: giving practical direction to diverse views, 245

Reply by the Federal Government to a question concerning new primary energy sources raised in the Bundestag, 57

Reply from the Federal Government concerning new pritery energy sources, 55

Research, developnent, and the energy crisia. Hearing before the Subcomittee on Energy of the Committee on Selence and Astronautics, U.S. House of

Representatives, Ninety-Third Congress, First session, Novenber 20, 1973, 272

Research, development, and the energy crisis. Hearings 
held November 20, 1973, 383

Results of an opinion survey on the 1977 budget proposal of the Energy Research and Development Adninlstration. Printed at the request of Henry $M$. Jackson, Chal raan, Comittee on Interior and Ineular Affalrs, United States Senate, 86

Self-sufflelency In energy (United KIngdon), 176

Some issues regarding regulatory pollcy, political particlpation, and soclal implications of geotheraal resource development in the Imperial Valley, 74 (NP21381)

Some reflections on the history of the United Nations and U.S. Government geothermal activities, 177

state pollcies for geotheral development, 85 (NSF/RA760230 )

state policy considerations for geothermal development In Hawa 11, 171

State responses to the energy crisis, 301

State taxetion of geotherali resources compared with state taxation of other energy alnerals, 133

statement at hearings before the Comittee on Interior and Insular Affalra (Four Corners Area), 433

studies in energy tax polley (Book), 208

Sumary report of the Cornell workshop on energy and the environment. Hearing pursuent to 5 . Res. 45, a national fuels and energy pollcy tudy, U. S. Senate, February 22-24, 1972, 404

The energy crisis and proposed solutions. Panel discussions before the Committee on Ways and Means, House of Representatives, Ninety-Fourth Congress, First session on the energy crisis and proposed solutions, part 3 of 4,201

Touard a national policy on energy resources and mineral plant roods. (Special publication), 361 (PB-230248)

Toward a national energy policy (Agencies edministering energy and attendent pollcy probieas), 356

Towards a responsible energy policy (Integration of economic and ethical factors), 197

ENERGY POLICY/BUDGETS

An analysis identifying lasues in the fiscal year 1976 ERDA budget. Report prepared for the Comittec on Selence and Technology, U.S. House of Representatives, Comittee on Interlor and Insular Affairs, U.S. Senate and the Joint Comittee on Atomle Energy, NinetyFourth Congress, First session, 209

ENERGY POLICY/DECISI ON MAKING

Energy technology update for Colorado dectsion makers. Proceedings of a conference held March 5, 1975, in Golden, Colorado, 220

ENERGY POLICY/EVALUATIONS

An analysis of the ERDA plan and progran, 153 (PB-250636) ENERGY POLICY/GEOTHERMAL ENERGY

Geothermal laws and regulations in the western United States, 296

The potential for energy production fron geothermal resources: Report of the Subcomalttee on Uater and Power Resources, Connittee on Interlor and Insular Affatrs, United states Senate, Ninety-Third Congress, First Session, 324

ENERGY POLICY/HEARINGS

Geothermal energy. Hearings before the Ninety-Second Congress, First Session, U. S. House of Representatives, Comittee on Sclence and Astronautics, Subcommittee on Energy, 371

ENERGY POLICY/LEGAL ASPECT

Energy in soclety (Worldwide policy distribution and development), 370

ENERGY POLICY/LEGISLATION

Energy cholces and public pollcy, 158

S.1283, National Energy Research and Development Policy Act of 1973,359

U.S. taxes on energy resources, 183

ENERGY POLICY/NATIONAL DEFENSE

Energy crisis: revision In U.S. policy to preserve national security, 330 (AD-778886)

ENERGY POLICY/PETROLEUM

U.S. taxes on energy resources, 183

ENERGY POLICY/PLANNING

Callfornta's energy future, 88

Energy systems. I, 260

Regulatory, planning and pollcy aspects of geothermal energy development in Iaperial County, California, 4

ENERGY POLICY/RECOMMENDATI ONS

Californla's energy ruture, 88

ENERGY POLICY/RESEARCH PROGRAMS

U.S. energy $R$ and $D$ : pollcy and prioritles, 29

ENERGY POLICY/REVIEUS

Review of the Project Independence report subnitted to office of Energy Research and Development, National Sclence Foundation, January 10, 1975, 195 (PB-238791) ENERGY POLICY/TAXES

U.S. taxes on energy resources, 183

ENERGY POLICY/TEXAS

Energy In Texas. Volume II. Pollcy alternatives, 28I

Iapact of state and lederal law on development of geotheraal resources in Texas, 299

ENERGY POLICY/TRADE

U.S. taxes on energy resources, 183

ENERGY SHORTAGES

Continuing energy crisis in America, 210

ENERGY SHORTAGES/FORECASTING

America's energy potential: a sumary and explanation prepared by Congressman Morris K. Udall, Chairman, Subcomalttee on the Envi ronment for Use of the Confittee on Interior and Insular Affelrs of the U.s. House of Representetives, Ninety-thlrd Congress, Firat Session, October 1973, 386

ENERGY BHORTAGES/LEGAL ASPECTS

Energy in soclety (Worldwide polley distribution and development). 370

Community planning, 164 (JPL-5040-6(Vol.3))

Cooperative efforta by Industry and government to develop geothermal resources, 241 (NSF/RA/N-74-159)

Econonic Impact of geothermal energy development, 5

Federal role In geothermal resource development, 18

Geothermal energy resources, 156 (CONF-750720-)

Geothernal energy: the challenges that lle ahead (Part 2 of a two-part article), 193

Inpact of tate and federal law on development of geothermal resources in Texas. Project L/R-9, pinal report, 254 (NSF-RA-N-74-244)

Impacts of energy resources removal from Federal and Indian lands, 282

Inperial Valley's proposal to develop a gulde for geothermal development within its county, 240 geotheraal developm
(NSF/RA/N-74-159)

Indiens cautlous on development, 32

Institutional and environmental espects of geothermal energy development, 1

Institutional and environmental aspects of geothermal energy development, 92

Institutlonal barriers to geothermal energy development. second report of the Institutional Barrier Panel to the Geothermal Advisory Council, 134

Legal. Institutional, and political probleas in producing lectric power from geothermal resources in California, 144

Multipurpose geotheraal resource developaent: an overview, 114

Public Interest vs. private partisanship in geothermal devel opment, 178

Regulatory, planning and policy espects of geotheralal energy development in Imperlal County, California,

Report to the Congress: problews in identifying, developing, and using geothermal resources, 190 (NP20694)

ENERGY SOURCE DEVELOPMENT/COST

Cost of geothermal energy development. Final report, January 1977,3

ENERGY SOURCE DEV́ELOPMENT/ECONOMIC IMPACT

Multisector analysis of the impact of geothermal development on the economy of Imperial County. Callfornia, 28

ENERGY SOURCE DEVELOPMENT/ECONONICS

Potential national benefits of geothermal electrical energy production from hydrothermal resources in the West, 97

ENERGY SOURCE DEVELOPMENT/ENUIRONMENTAL IMPACTS

Energy development and land use In Texas. Final report on Project E/S-1: Impact on land use and value of alternatlve strategles for production, distribution, and utillzation of energy in rexas in the period 19742000,211

Geographical environental analysis. Final report, 29

Institutional and environmental problens in geothermel resource development, 243 (NSF/RA/N-74-159)

ENERGY SOURCE DEUELOPKENT/FINANCTAL INCENTIVES

U.S. Energy Resources Development Adainistration: Geotheraal Loan Guaranty Progran, 228

ENERGY SOURCE DEVELOPHENT/FINANCING

Benefits of stimulating geothermal energy development with tax and research subsidies, 143

ENERGY SOURCE DEVELOPMENT/HEARINGS

Federal Energy Adainlstration hearing on western regional resource development, 246

ENERGY SOURCE DEVELOPMENT/LAWS

Legal issues in the developaent of geopressured geothermal resources of Texas and Loulsiana Gulf coast (Sumary) (Resource definitions in statutes of is states), 31

ENERGY SOURCE DEVELOPHENT/LEGAL ASPECTS

Institutlonal barriers to geothermal energy development. A report by the Institutional Barrier Panel to the Geothermal Advi sory Council, 135

ENERGY SOURCE DEVELOPNENT/PLANHING

Interdisciplinary planning for geotheraal development at the county level, 99

ENERGY SOURCE DEVELOPHENT/RESEARCH PROGRAHS

Federal organization for nonnuclear energy research and development activities of departments and agencles other than ERDA: FY 1976, 175 (NP-20699)

ENERGY SOURCE DEVELOPHENT/SOCIO-ECONOMIC FACTORS

Boom towns way hinder energy resource development, 72

ENERGY SOURCE DEVELOPMENT/TAXES

State taxation of geothermal resources compared with state taxation of other energy minerals, 133

ENERGY SOURCE DEVELOPMENT/TECHNOLOGY ASSESSMENT

A technology assessment of geothermal energy resource development, 184 (PB-246241)

Technology forecast of United States geothereal energy resource development, 111

ENERGY SOURCE DEVELOPMENT/WATER REQUIREMENTS

Western states water requil rements for energy development to 1990,249 (NP-20555)

ENERGY SOURCE DEVELOPMENTS 
Role of otate government in the development of a geothernal resource, 369

ENERGY SOURCES

See l:o FOSSIL FUELS

$$
\text { NUCLEAR FUELS }
$$$$
\text { TIDAL POUER }
$$

Energy and the future (Book), 362

Introduction: the energy outiook (USA), 377

Toward at anal pollcy on energy resources and ineral plant roods. (Special publication), 361 (PB-230248)

ENERGY SOURCES/AVAILABILITY

Energy crisis: revialon in U.S. pollicy to preserve national security, 330 (AD-778886)

Profect Independence report, 287

ENERGY SOURCES/COMPARATIVE EVALUATIONS

Energy alternatives: comparative analysis, 214

ENERG SOURCES/DEMAND FACTORS

Energy and wateriala, 384

Summery report of the Cornell workshop on energy and the environment. Hearing pursuant to S. Res.45, nat Ional $f_{\text {uel }}$ and energy poll cy study, U. S. Senate. Fobruary 22-24, 1972, 404

ENERGY SOURCES/DISTRIBUTION

Energy in soclety (Worldwide pollcy distribution and developaent), 370

ENERGY SOURCES/ECONOMICS

Energy alternatlves: comparative analysis, 214

Energy econowlcs, 56

ENERGY SDURCES/EFFICIENCY

Energy alternatlves: a comparative enalysis, 214

ENERGY SOURCES/ENERGY POLICY

Energy crisis: revision in U.S. polley to preserve national security, 330 (AD-778886)

Netural resources development and policies, Including environmental considerations. Note by the secretaryGeneral: Addendua, changing patterns in the Horld energy ituation, 438

Reply by the Federal Governeent to question concerning neu pilary eneroy sources ral sed in the Bundeatag, 57 ENERGY SOURCES/ENUIRONMENTAL EFFECTS

Energy alternatives: comparative analysis, 214

studies in energy tax policy (Book), 208

U.S. energy R and D: polley and priorities, 294

ENERGY SOURCES/F INANCING

Finencing inf rastructure in energy development areas in the West. Proceedings of conference held August 21 and 22,1975 , in Snowb ird, Utah, 218

ENERGY SOURCES/FORECASTING

America' energy potential: a sumary and explanation prepared by Congressman Morr 1 . K. Udall, Chalrman, Subcomiltee on the Enviroment for Use of the Comittee on Interlor and Insular Affalrs of the U.S. House of Representatives, Ninety-thlrd Congrese, First Session, Det ober 1973, 386

ENERGY SOURCES /GOVERWMENT POLICIES

Indians cautious on development, 32

Mining and winerals policy: 1976 blcentennial edition, $42(\mathrm{NP}-21355)$

stete responge to the energy crisse, soi

U.S. energy $R$ and $D$; policy and priorities, 29

ENERGY SOURCES/LEGISLATION

Electric power, fuel development, and protection of the environment: leglelation introduced in the 91 ot

Congress, 451 and public polley, 158

ENERGY SOURCES MEET INGS

Energy technology update for Colorado deciolon akers. Proceedings of a conference held Harch 5,1975 , in Golden, Colorado, 220

Proceedings of citizeng' forua on potential future energy ources held at Portland, Oregon, January 17, 1974. 223

ENERGY SOURCES/NET ENERGY

Energy analysts and public pol tcy, 155

SNERGY SOURCES/PLANNING

Administration's energy message and program: the need for prompt development of a national energy pollcy, 406

Energy and materlais, 384

Eneroy eystems. I, 260

Engineering manpower and energy needs. IV. Federal polleles have an impact, 149

Longer-range technologleal potentlale for energy development: an asesament of the prospects in new energy technology, $\mathbf{4 0 5}$

Self-suffictency In energy (United Kingdom), 176

ENERGY SOURCES/PRODUCTION

Amerlea's energy potential: cummary and explanation

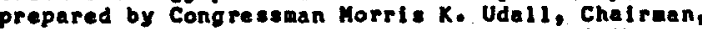
cubcommittee on the environment for use of the Comittee on Interior and Insular Affairs of the U.S. House of Representatlves, MInety-Thlrd Congress, First seselon, Detober 1973,363

Energy outloak for the $2980^{\prime} \mathrm{s}$. A atudy prepared for the use of the Subcomittec on Economic Progreas of the Joint Econoulc Comittee, Ninety-Third Congress. Firet sesesion, by W. N. Peach, December 17, 1973 (Revieu), 388

Prestdent 's measage on energy, 1973, 373

ENERGY SOURCES/RECOMHEHDAT IONS

Revlew of Profect Independence Blueprint panel cubcomittee reports on FEA-interagency task forces. Report on CTAB recomendations for ational energy program. Subcomblttee working documents, 198 (COr-7510500)

ENERGY SQURCES/RECOUERY

Impacta of energy resources removal from federal and Indi an lands, 282

ENERGY SOURCES/RESEARCH PROGRAMS

Energy research and development. Ninety-ThIrd Congress, First Session, December 1, 1973, 387

Federal energy/environmental research and development progran, 212

National plan for energy research, development and demonstration: creating energy cholces for the future. Volune 2. Program inplementation, 84 (ERDA-76-1(Vol.2)

Observations on Federal Energy Research and Development; Decenber 1974,71

Reply from the Federal Government concerning new primary energy sources, 55

S.1283, Nat I onal Energy Research and Development Policy Act of 1973,359

U.S. energy R and D: pollcy and priorities, 294

ENERGY SOURCES/REVIEUS

Briefing on energy policy, 385

ENERGY SOURCES/SYSTEMS ANALYSIS

Energy analysia and public polley, 155

ENERGY STORAGE/PLANNING

Longer-range technological potentials for energy development: an assasment of the prospects in new energy technology, 405

ENERGY SUPPLIES

Energy, Volume I. Denands, resources, Impact technology, and polley (Book; compllation of lecture notes), 295

ENERGY SUPPLIES/ENERGY POLICY

Netural resources development and pollcles, Including envi ronmental considerations. Wote by the SecretaryGeneral: Addendum, changing patterns in the World energy situation, 438

Toward a natlonal poll cy on energy resources and mineral plant foods. (Special publication), 361 (PB-230248)

ENERGY SUPPLIES/MARKET

Energy company: a monopoly trend in the energy arkets 430 ( $\mathrm{PB}-218830)$

ENERGY SUPPLIES/PLANNING

Englneerling manpower and energy needs. IV. Federal polleles have an Impact, 149

Self-sufficiency In energy (United KIngdon), 176

ENERGY SUPPLIES/RESEARCH PROGRAMS

President's message on eupply of energy and clean afr, also fact heet from office of the White House Prese Secretary, 425

Reply from the federal Government concerning new primary energy sources, 55

ENERGY SUPPLIES/SECURITY

Energy self-sufficiency: how much; how soon, 216

ENERGY TRANSPORT/FINANCING

Financing infratructure in energy development areas in the Uest. Proceedings of a conference held August 21 and 22,1975, in Snowbird, Utah, 218

ENGLAND

SeE UNITED KINGDOM

ENUIRONMENT

Analys 1 s of the ERDA plen and prograe, 205

Authorizing approprlations for the Energy Research and Development Adminlatration.

Benefit of stimulating geothermal energy development with tax and research oubsidles, 143

California public resources code: otatutes pertalning to geothe rabl resources, 348

Dectaion taterent of Secretary of Interlor on geotherad 1 resources progran, 267

Department of the Interior final statement, 353

Economic impact of geothermal energy development, 5

EIR's: truth and consequences, 306

Eneray and the future, 362

Energy cholces and public pollcy, 158

Energy research and development. Ninety-Third Congreas, First Sesion, Decenber 1, 1973, 387

Energy taxes and subsidies, 314

Environmentally sensit tve land use regulation in Callfornia, 357

Environatental aspects of nuclear etinulation, 380

ERDA uthorization, Fiscal Year 1977. Part IV. Baste energy eclences. Hearlings before the Subcomittee on Energy Research, Development and Demonetration of the Committee on Sclence and Technology, U.S. House of Representatives, Ninety-Fourth Congress, Second sesalon, February 26, 1976, 129

federal regulations and lease terms and thefr regulationship to state laws and regulations. 303

Geotheraal energy prograe. Subpanel report VIII used In preparing the AEC Chairwan's report to the prealdent, 325 (UASH-1281-8)

Geothermal Environmental Advieory Panel. Second annual report, July 1,1975 -June 30, 1976, 136

Geothermal resources research, 375

Geothermal stean Act of 1970. Public Law 91-581, Senate Res. 368, 91 at Congress, December 24, 1970, 391 Geothermal resources research, 394

Geothermal resources research,

Institutional barriera to geothermal energy development. $A$ report by the Institutional Barrler Panel to the Geothermal Advisory Councl 1,135

Interrelationshlp between tederal, state, and local 
regulatory agencies on the development of the

geothertal resource in Caltfornia, 342
Introduction: the energy outlook, 377

Introduction: the energy outlook, 37
Law needed for geothermal energy, 268

Nation's energy future. A report to Richard M. Nixon, President of the United States, 322 (WASH-1281)

Natural resources developnent and polfcles, including environmental considerations, 437

President's message on supply of energy and clean air, also fact sheet from office of the White House Press Secretary, 425

Presidential energy statements. Printed at the request of Henry M. Jackson, Chairman, Comittee on Interior and Insular Afrairs, United States Senate, NinetyThird Congress, First Session, pursuant to $S$. Res. 45, a national fuels and energy policy study, 364

Protecting the environment (Chapter in Encyclopedia of Energy), 101

Research and devel opment, 46 (JPL-5040-25(Rev.A X App.))

Results of an opinion survey on the 2977 budget proposa of the Energy Research and Development Adeinistration. Printed at the request of Henry M. Jackson, Chal rman, Coamittee on Interior and Insular Afrairs, United States Senate, 86

Soclal Implications may arise with future geotkermal usage, 93

Some interfaces in resource utilization, 484 (LA-UR-73$570)$

Some issues regarding regulatory policy, political participation, and social implications of geothermal resource deveiopment in the Imperial Valley, 142

Summary guide to the institutional problems.confronting the geothermal energy industry, 244 (CONF-741145-1)

Summary report of the Cornell workshop on energy and the environment. Hearing pursuant to $S$. Res. 45, a national fuels and energy pollcy study, U. S. Senate, February 22-24, 1972, 404

Summer Lake Basin geothermal leasing: Environmental Analysis Record, 51 (NP-21256)

Teras, conditions, standards, and application procedures for initial geothermal development: Imperial County, California, 351

Toward a national energy pollcy, 356

U.S. taxes on energy resources, 183

ENVIRONMENT/GOVERNMENT POLICIES

Geothermal Environmental Advisory Panel. First annual report, June 1, 1974-June 30, 1975 (Preparation of guidel ines for Industry compliance witenvi ronmental monitoring), 225

Public pollcy toward environment 1973: a review and appraisal. Nuclear and other energy, 358

ENVIRONHENT/LAWS

Environgental laws and regulations, 166 (JPL-5040-6(Vol. 3))

Interstate environmental problems: a guide to water pollution and water scarcity, 317

ENVIRONHENT/LEGISLAT ION

Electric power, fuels development, and protection of the environment: leglslation introduced in the 91 st Congress, 451

ENUI RONMENT/PRESERUATION

Public interest va. private partisanship in geotheral development, 178

ENUIRONMENT/REGULATIONS

Envi ronmental laws and regulations, 166 (JPL-5040-6(Vo). 3)

ENUIRONMENT/RESEARCH PROGRAMS

Federal energy/environmental research and development progran, 212

ENUIRONMENTAL EFFECTS

Energy: the new era (Book), 273

ENUIRONMENTAL IMPACT STATEMENTS

Adminietrative law of Californla's resources agency: portion of the directions for prepering environiental Inpact reports, 350

Coaments on draft environmental impact statement for the federal geotheraal leasing prograns, 436

Envi ronmental impact atement for the Geothermal Leasing Prograw, 392

Environmental impact tatement for the geotherad leasing progran; draft, 422

Federal government leasing and operating regulations and envi ronmental impect statements, 414

Final environsental statement for the geothermal leasing program. Volume I. Promulgation of leasing and operating regulations, 360 (NP-20212)

Final environmental staterent for the geothermal leasing progran. Volume 1,365

Final environmental statement for the geotheras leasing program. Volume II, 366

Final environmental statement for the geothermal leasing progran. Voluae III, 36?

Final environmental statement for the geotheraal leasing progran. Volume IU; 368

Geothermal Leasing Program. Volume I. Promulgation of leasing lond oping Prot environmental Impact tatement, 326 (EIS-CA-73-1681-F1)

Geothermal Leasing Progren. Volume II. Leasing of geothermal resources in three Californla areas. Final environmental inpact etatement (Clear Lake, Mono lake, Iteperial Valley); 327 (EIS-CA-73-1681-F-2)
Geothermal Leasing Program. Volume III. Appendices A through H. Proposed geothermal, leasing, and operating regulations. Final environmental impact statement, 328 (EIS-CA-73-1681-F-3)

Geothermal Leasing Program. Volue IV. Appendix I. Comments on draft iapact statement and proposed regulations. Final envi ronmental impact statement, 329 (EIS-CA-73-1681-F-4)

Geothermal leasing progran, considers impact of leasing and operating regulations to Implement the Geotheraal Stean Act of 1970 and leasing of 3 areas in Calffornia.; Draft environmental impact tatement, 421 (PB-203102-D)

Geothermal Leasing Program, 396 (PB-208954)

Geothermal leasing program. (Supplement to draft dated 6 oct 1971, $P B-203102-D), 397$ (PB-208954)

Geothermal leasing program (draft environental Impact statement), 431 (PD-218830)

Geothermal Energy Research, Development, and Demonstration Act of 1974. Oversight hearings: loan guaranties. Hearings before the Subcommittee on Energy Research, Development, and Demonstration of the Committee on Science and Technology, U.S. House of Representatives, Ninety-Fourth Congress, first session, 207

Geothermal steam and resources, 446

Implementing the federal geothermal steam act of 1970 , 429 (CONF-710571-)

Indians cautious on development, 32

Interrelationship between federal, state, and local regulatory agencles on the development of the geothermal resource in Callfornla, 342

ENUTRONMENTAL IMPACT STATEMENTS/REGULATIONS

EIR's: truth and consequences, 306

ENVI RONMENTAL IHPACTS

Benefits and costs to landowners frow geotheral resource lease and development, 140

Community planning, 164 (JPL-5040-6(Vol .3))

Development of geothermal energy in the Guif cost: socio-economic, demographic, and political considerations, 82 (CONF-760222-P5)

Econonic impact of geothermal energy development, 5

Effects of geothermal development on the agricultural resources of the Imperial Valley, 6

Energy development and land use in Texas. Final report on Project E/S-1: inpact on land use and value of alternative strategles for production, distribution. and utilization of energy in Texas in the period 19742000,211

Environmental assessment of proposed geothermal well testing in the TIgre Lagoon oil Field, Vermilion Parlsh, Loulsiana, 68 (TID-27034)

Environmental overview of geothermal resources development, 22

Environmental impacts of geothermal resource development on comerclal agriculture: a case study of land use conflict, 131

Environmental impact of geothermal power plant, 188

Environmental planning for the geothermal leasing program on public lands, 285

Environentaliy sensitive land use regulation in Callfornia, 357

Geographical envi ronnental analysis. Final report, 29

Geothermal resources of the Texas Gulf Coast: environmental concerns arising from the production and disposal of geothermal waters, 83 (CONF-760222-P5)

Geothermal leasing practlces, 12

Geothermal resources operational order No. 6: plpelines and surface production faclilties, 26

Geotheral energy: prospects and limitations, 109

Geothermal energy and its uses: technical, economic, environmental, and legal aspects, 110

Geothermal Envíronmental Advisory Panel. Second annual report, July $1,1975-J u n e ~ 30,1976,136$

Geothermal energy: an Induatry appraisal, 232

Geothermal resources operational Order No. 1: exploratory operations, 234

Geothermal resources operatlonal Order No. 4 : general onvironaental protection requirements, 237

Inpact of energy resources removal from Federal and Indian lands, 282

Iaperial Valley environental project, 59 (UCRL-52000-765

Institutional and environmental probleis in geothermal resource development, 243 (NSF/RA/N-74-159)

Institutional and environmental aspects of geothernal energy devel opnent, 1

Inst Itutional and environmental aspects of geothermel energy development; 92

Legal, institutional, and political problems in producing electric power from geothermal resources in callfornia, 144

Dverview of the Californit permitting process, 23

Proceedings of the energy research priorities conference held at Berulck Acadewy, South Berwick, Maine, July 30August 4, 1972, 483 (CONF-720742-)

Proceedings of the workshop on environmental espects of geotheral resources development, 20-22 september 1974,

Public opinion concerning geotheras developaent in Like County, Call fornia, 65 (LBL-4447)

Public opinton in Cobb Veiley concerning geotheraal development in Lake County, Californla, 50 (LBL-5204)

Review of Project Independence Blueprint panel subcomittee reports on FEA-interagency task forces. 
Report on CTAB recomendations for atlonal energy progran. Subcomalttee working documentif, 198 (COM-7510500 )

state policy considerations for geothermal development in Hawall, 171

gumer Lake Basin geothermal leasing: Environmentel Analyeis Record, 51 ( $(N P-21256)$

ENUIRONMENTAL PROTECTION AGENCY/RESEARCH PRDGRAMS

Federal organization for nonnuclear energy research and development sctivities of departments and ogencles EPA other than ERDA: FY 1976, 175 (NP-20699)

See ENVIRONHENTAL PROTECTION AGENCY

EXPLOSIVE STIMULATION/ENVIRONMENTAL EFFECTS

Environmental aspect of nuclear stimulation, 380

FEDERAL POWER COMMISSTON/ENERGY POLICY

Energy regulation by the Federal Power Commlasion, 316

DERAL REP

Se GERMAN FEDERAL REPUBLIC

FINANCIAL INCENTIVES

Californla geothermal resources: how well are we dolng. 124

Electric utilty companies and geotheral power, 98

Energy taxes and subsidies, 314

Federal role in geothermal resource development, 18

Geothermal exploration and development in the United States: tax analysis under the internal revenue code, 117

Geothernal power: strangled by red tape, 169

Geothermal exploration and development in the United States: tax analyais under the Internal Revenue Code, 230

Inst itutional barriers to geothermal energy development second report of the Institutional Barrier Panel to the Geothermal Advisory Councli, 134

Property systems in geothermal resources: a citlque and recommendation 8,118

Reich, A.E. -t al. ve Commissloner of Internal Revenue and G.D. Rowan et al. vs Conmlesioner of Internal Revenue. U.S. Court of Appeals, Ninth Circuit. January 21, 1972,416

Reich, Arthur E. and Carolyn C. Reich vo Comal asion of Internal Revenue, U.8. Tax Court, July 31, 1969, 456

U.S. Energy Resources Development Adainistration: Geotheraal Loan Guaranty Progran, 228

uctory Sand and Concrete. Inc. vs Conmissloner of Internal Revenue, January $2,1974,319$

FINANCIAL INCENTIVES/COST BENEFIT ANALYSIS

Benefits of stimulating geothermal energy development with tax and research subsidies, 143

\section{FINANCING}

Authorizing approprlations for the Energy Research and Development Adminietration. Conference report to accompany H.R. 13350,106

Benefits of stimulating geothermal energy development it th tox and research subsidies, 143

california public resources code: tatutes pertaining to geothermal resources, 348

Economic and soctal aspects of geothermal energy resource developaent, 128

Electric utllities, 163 (JPL-5040-6(Vol.3))

Exploration and development of geothermal resources in the United States, 1968 to 1975,113

Federal role in geothermal resource developnent, 18

Financial aspects of geotheral resources developaent San Francisco, Cal ifornia, October 23-24, 1975, 226

Financing infrastructure in energy development areas in the West. Proceedings of conference held August 21 and 22,1975 , In Snowbird, Utah, 218

Formation, funding, and development of a small exploration company, 231

Geothermal energy research, development, denonstration, and production: Federal guarantes on loans, 58

Geothermal Federal loan guarantee program (federal Reglster), 148

Geothermal Energy Research, Development, and Demonstration Act of 1974. Oversight hearings: loan guaranties. Hearings before the subcomittee on Energy Research, Developent, and Demonstration of the Committee on Science and Technology, U.S. House of Representatives, Ninety-Fourth Congress, first session, 207

Geothermal energy development. Hearing before the Subcomittee on Energy Research and Water Resources of the Comittee on Interior and Insular Affairs, United States Senate, Ninety-Fourth Congress, First Session, 217

Geotheral tax considerations and shelters, 229

Geothermal energy: an Industry appralsal, 232

Geothermal resources research and technology, 245

Geothermal energy exploration, research, and development. Report of the Comittee on Interior and Insular Afraira, United States Senate, NInety-Third Congress, Second Session to accompany S. 2465,280

Geothermal Energy Research, Development, and Commercial Denonstration Act of 1973; Geothermal Energy Research, Development, and Demonstration Act of 1974. Hearings before the subcomit tee on Energy of the Committes on before the Subcomplttee on Energy of the
selence and Astronautics, U.S. House of
Representetives, Ninety-Third Congress, Second Session on H.R.11212 and H.R.14172, 300

Geothermal resources - operations on publle, acquired and withdrawn lande; notles of proposed rulemaking, 346

Institutfonal barriere to geothermal energy developaent. A report by the Institutional Barrier Panel to the Geothermal Advisory Council, 135

Institutional, business, and financial aspects of the geothermal energy industry, 252

Institutional, business, and financlal aspects of the geothermal energy Industry (abstract), 257

leasing on public, acquired and withdrawn lands: revilat on of proposed rule, 347

Legal, Inatitutional, and polltical problens in producing electric power fron geotheral resources in Callfornia, 144

Majority opinion in the Relch cases question of depletion, 352

Recent deveiopments in the taxation of geothermal exploration, 196

Recent developments In the taxation of geothermal exploration, 485

Relch, Arthur E. and Carolyn C. Relch va Comeission of Internal Revenue, U.S. Tux Court, July 31, 1969, 456

Role of municipalities in geotherabl resource developuent, 14

status of conomics and financing geothermal energy power product 1 on, 227

studies in energy tax polfey, 208

Sunmary of Section XI: economic and financlal aspects, 108

Susanville Geothernal Ut1lity System, 41 (SAN-1077-4)

Tax treatment of exploring and developing geotheral resources, 334

Teras, conditlions, standards, and application procedures for initial geotheral development: Imperiai County, Callfornia, 351

U.S. Energy Resources Development Adminlatration: Geothermal Loan Guaranty Program, 228

Utility partleipation In geothermal energy source, 293

FOSSIL FUELS See a 1 SO COAL NATURAL GAS PETROLEUY

FOSSIL FUELS/PROCESSING

Protecting the environment (Chapter in Encyclopedia of Energy); 101

FOSSIL FUELS/PRODUCTION

Protecting the environment (Chapter In Encyclopedia of Energy), 101

FPC SEe FEDERAL POUER COMMISSION

FRANCE/ENERGY POLICY

Energy politics of France, 78

FRANCE/ENERGY SOURCES

Energy politics of France, 78

FUSION REACTORS

SEe THERMONUCLEAR REACTORS

G

GAS COOLANTS

GASES

SE I I NO NATURAL GAS

GASES/LEGAL DEFINITIONS

Relch, A.E. et al. vs Commisstoner of Internal Revenue and G.D. Rowan t al. vs Commlssioner of Internal Revenue. U.S. Court or Appeals, Ninth Circult. January 21, 1972 (Judicial Interpretation of IRS tax regulations relative to depletion allowance for geothermal well drilling and development; 26 CFR 1. $263(\mathrm{c}), 1.611(\mathrm{a})$, and $1.613(\mathrm{~b})), 416$

GEOLOGIC DEPOSITS/HEAT SOURCES

Technical overview of geothermal resources, 11 GEOPRESSURED SYSTEMS

Development of geothermal energy in the Gulf coast: socio-econonlc, demographic, and political considerations, 82 (CONF-760222-P5)

Geothermal energy resources (Group posit Ion paper, 3 subgroup papers, and 1 review paper), 156 (CONF-750720-

Geotheraal resources of the Texas Gulf Coast: environmental concerns arialng from the production and disposal of geothermal waters, 83 (CONF-760222-P5)

Legal issues in the development of geopressuredgeothermal resources of Texas and Loulsiana Gulf coast, 81 ( CDNF-760222-P5)

GEOPRESSURED SYSTEMS/ECONOMICS

Analysis of the potential use of geothermal energy for power generation along the Texas Gulf Coast, 150 (NSFRA-N-74-246)

GEOPRESSURED SYSTEMS/ENERGY SOURCE DEVELOPMENT

Inpact of state and federal law on development of geotheral resources in Texas. Project $L / R-9$. final report, 254 (NSF-RA-N-74-244)

GEOPRESSURED SYSTEMS/ENUIRONMENTAL EFFECTS

Legal, Institutional, and environmental, 79 (CONF-760222P1)

Proceedings of second geopreasured geothermal energy 
conference, Austin, Texas, Fobruary 23-25, 1976. Volume $V$. Legal, Institutional, and envi ronmental, 80 (CONF-760222-P5)

GEOPRESSURED SYSTEMS/ENVIRONMENTAL IMPACTS

Envi ronmental ssessnent of proposed geothermal well testing in the Tigre Lagoon of i Field, Veralilion Parlsh, Loulelana, 68 (TID-27034)

GEOPRESSURED SYSTEMS/LAUS

Legal Isaues in the development of geopressured geothermal resources of Texas and Loulsiana Gulf Coast (Summary) (Resource definitions in statutes of 15 states), 31

GEOPRESSURED SYSTEMS/LEGAL ASPECTS

Legal, Institutional, and environmental, 79 (CONF-760222P1)

Proceedings of second geopressured geothereal energy conference, Aust In, Texas, February 23-25, 1976. Vol uae V. Legal, Institutional, and environmental, 60 (CONF-760222-P5)

GEOPRESSURED SYSTEMS/POWER POTENTIAL

Analysis of the potentlal use of geothermal energy for power generation along the Texas Gulf Coast, 150 (NSFRA $-\mathrm{N}-74-246)$

GEOPRESSURED SYSTEKS/SOCIO-ECONOMIC FACTORS

Proceedings of second geopressured geotheral 1 energy conference, Austin. Texas, February 23-25, 1976. Volume $v$. Legal, institutional, and envi ronmental, 80 (CONF-760222-P5)

GEOTHERMA STEAM ACT

Geothermal steam act of 1970 (explottation and development of geothermal steam resources), 447 (PD218830)

GEOTHERMAL ENERGY

Al ternative sources of energy: practlcal technology and philosophy for a decentralized society, 213

Cont inuing energy crisis in America, 210

Energy from geothermal resources. Report prepared for the Subcomittee on Energy of the Comittee on Selence and Astronautics, U.S. House of Representatives,

Ninety-Third Congress, Second Session, 289

Geothermal world directory, 89

Geothermal power, 374

Natural resources development and policies, including envifonmental considerations, 437

President's message on supply of energy and clean alr, also fact sheet from Orflee of the White House Press Secretary, 425

Proceedings of citlzens' forum on potentlal future energy sources held at Portland, Dregon, January 17, 1974,223

Uestern states water requirements for energy developant to 1990,249 (NP-20555)

GEOTHERHAL ENERGY/AVAILABILITY

Geothermal energy as an 'alternative' source, 54

Project Independence blueprint: final task force report. Geotheraal energy, 288

GEOTHERMAL ENERGY/BIBLIOGRAPHIES

Geothermal energy. Volume I. 1964-April 1975 (citations from the NTIS data base). Report for 1964-Apr 1975 (148 Abstracts), 52 (NTIS/PS-76/0462)

Geotheracl energy. Volume 2. 1975-April 1976 (citations from the Engineering Index date base). Report for 1975-Apr 1976, 53 (NTIS/PS-76/0465)

Geothermal resources: exploration and exploltation. A bibllography, 43 (TID-3354-R1)

Geothermal energy. Volume 2. Search perlod covered: May 1975-April 1976. Cltations frow the NTIS Data Base, 137

Geothermal energy. Volume 1. Search perlod covered: 1970-1974. Citations from the Engineering Index Data Base, 138

Geothermal power economics: an annotated bibliography, 278

Power from the Earth: geotheraal energy, 411

Summary and concluding rewarks, 24

GEOTHERMAL ENERGY/BUDGETS

ERDA authorization, FIscal Year 1977. Part III. Geothermal. Hearing before the subcomittee on Energy Research, Development and Demonstration of the Coanit tee on Science and Technology, U.S. House of Representatives, Ninety-Fourth Congress, Second Session. February 19, 1976, 132

GEOTHERMAL ENERGY/CONTRACTS

Geothermal sales contracts, 21

GEOTHERMAL ENERGY/COST

Analysis of the potential use of geothermal energy for power generation along the Texas Gulf Coast, 150 (NSF$\mathrm{RA}-\mathrm{N}-74-246)$

Callfornia public utllities comalssion.s 146

Costs of geothermal energy development. Final report, January 1977,3

GEOTHERMAL ENERGY/ECONOMIC DEVELOPMENT

Greider geothermal tatement, based on testimony presented to Lt. Gov. Dymally Comalttee (Development of geothermal (industry), 62

Inst I tutional, business, and financial apects of the geothermal energy Industry (abatract), 257

Potential national benefits of geotherel lectrical energy production from hydrothermal resources in the energy prod

Technology forecast of United states geothermal energy resource development, 111
UtIlity partlcipation In geotheraal energy source, 293 GEOTHERMAL ENERGY/ECONOHIC POLICY

Alternative energy sources for the UR, 77

GEOTHERMAL ENERGY/ECONOMICS

Earth'g heat tapped for geotheranal power developnent, 420

Econoulc and engineering Implications of the profect

Independence 1985 geotheral energy output goal and

the associated sensitivity anaiysis, 96

Economics of geotherwal power in the United states, 449

Geothermal energy and Its uses: technical, econosic,

environtental, and legal aspects, 110

Geotheraal power cononics: an annotated blbliography, 278

Geothermal world directory, 401

Geothermal energy, its future and econosics, 419

Institutional, business, and rinancial espects of the geothermal energy industry, 252

Legal problems of the geotheraal Industry, 469

Relch case: econoalc Implications of depletion - llowances, 222

status of econoulcs and linancing geotheral energy power production, 227

Sumary of Section XI: ceonomic and fInancial especta, 108

Suganv1lle Geothermal Energy Project overview, 36 (SAN-

GEOTHERMAL ENERGY/ELECTRIC POWER

Electric utllity companies and geotheral power, 98

Free electricity; plan to get nore energy from heet inside Earth moves forward a bit (Geothermal stean act of 1970$), 442$

Geothermal resources in Callfornla, 408

GEOTHERMAL ENERGY/ENERGY POLICY

Constraints on geothermal development: tax and beyond. 19

Federal role in geothermal resource development, 18

Geothermal development pollcy for an isolated etate: the case of Hawal1, 119

The potential for energy production from geothermal resources: Report of the Subcommittee on yater and Power Resources, Committee on Interlor and Insular Affairs, United states Senete, Ninety-Third Congress, First Session, 324

GEOTHERMAL ENERGY/ENERGY SOURCE DEVELOPHEN

Costs of geothermal energy development. Final report, January 1977,3

Inst itut lonal barriers to geothermal energy development. A report by the Institutional Barrier Panel to the Geotheraal Advisory Council, 135

Regulatory, planning and polley aspects of geotherial energy development in Imperial County, Cailfornia,

GEOTHERMAL ENERGY/ENUIRONMENTAL EFFECTS

Compendiun of first day papers presented at the First Conference of the Geotheraal Resources Council, El Centro, California, Feb 1972, 412

Geothermal power economics: an annotated bibllography, 278

Proceedings of the workshop on environmental aspects of geotheraal resources development, 20-22 September 1974, 315

Protecting the environment, 101

The potential for energy production from geothermal resources: Report of the Subcomalttee on Vater and Power Resources, Comittee on Interlor and Insular Affalrs, United states Senate, Ninety-Third Congress, First Seselon, 324

U.S. energy $R$ and D: pollcy and prlorities, 294

GEOTHERMAL ENERGY/ENVIRONMENTAL IMPACT STATEMENTS

Environmental impact atatement for the Geothermal Leasing Program, 392

Federal government leasing and operating regulations and envi ronmental impact statements, 414

GEOTHERMAL ENERGY/ENVIRONMENTAL IMPACTS

Environmental lapects of geothermal resource developaent on commercial agriculture: a case study of land use conflict, 131

Geographical environmental analysis. Final report, 29

Geothernal energy: prospects and ileitations, 109

Geothermal energy and It uses: technical, economle, environwental, and legal aspecte, 110

Instltutional and environmental aspects of geothermal energy development, 92

GEOTHERMAL ENERGY/EXPLOITATION

Geothernal energy as an 'alternative" source, 54

Geotheraal energy: the challenges that lis ahead (Part 2 of a two-part art(cle), 193

Geotheral resources research and technology, 245

Tax treatent of exploring and developing geothermal resources, 334

GEOTHERHAL ENERGY/FEASIBILITY STUDIES

Other energy sources, 64 (CONF-760205-)

GEOTHERMAL ENERGY/FINANCING

Geothermal Energy Research, Development, and Demonstration Act of 1974. Oversight hearings: loan guaranties. Hearings before the Subcommittee on Energy Research, Development, and Demonetration of the Comittee on Science and Technology, U.S. House of Representetives, Ninety-Fourth Congress, First session, 207

Geothermal energy exploration, research, and development. Report of the Committee on Interior and Insular Affairs, United states Senate, Ninety-Third Congress Second Session to accompany $S, 2465,280$

Institutional, business, and financiai aspects of the 
geothernal energy Industry, 252

Legal, institutional, and poiltical problems in producing electric power from geotheral resources in california, 144

Role of municlpalities In geotherial resource development, 14

Status of economles and linaneing geothermal energy power production, 227

Susanvilie Geotheral Utllity Systen, 41 (SAN-1077-4)

U.S. Energy Resources Development Adalni stration: Geothermal Loan Guaranty Program, 228

GEOTHERMAL ENERGY/FORECASTING

Alternate energy sources for Hawall. Proceedings of the workshop held May 8-9, 1975, in Honolulu, Hawall 219

GEOTHERHAL ENERGY/GOVERNMENT POLICIES

Envi ronmental laws and regulatlons, 166 (JPL-5040-6( Vol. 3))

Geothermal activity in 1971,400 (PB-218830)

Geothermal energy: prospect, and ilitations, 109

Geothermal development policy for an isolated tate: the case of Hawali, 119

Geothermal power: strangled by red tape, 169

Geotheral Environmental Advisory Pane1. First annual report, June 1, 1974-June 30, 1975 (Preparation of guldelines for industry compiliance ith envi ronmental gonitoring , 225

Mining and inerals pollcy: 1976 blcentennial edition, $42(N P-21355)$

Prelininary report on legal and public policy etting for geothermal resource development in Hawall, 279

Report to the Congress: problens In Identifylng developing, and using geotheral resources, 190 (NP20694)

state policy considerations for geotheraal development In Hawall, 185 (PB-243467/8ST)

Sumary guide to the institutional problems confronting the geotherwal energy industry, 244 (CONF-741145-1)

GEOTHERMAL ENERGY/HEARINGS Compendi un of papers presented at the Inperial Valley--
8 alton sea rea geothermal hearing, Oct 22 and 23,450

ERDA authorization, FIscal Year 1977. Part III. Geothermal. Hearing before the Subcomittee on Energy Research, Development and Demonetration of the Comittee on Science and Technology, U.S. House of Representatives, Ninety-Fourth Congress, Second Session, February 19, 1976, 132

Geothermal energy development. Hearing before the Subcomplttee on Energy Research and Hater Resources of the Committee on Interior and Insular Affalrs : Unlted States Senate, Ninety-Fourth Congrese, First seselon, 217

Geothermal energy. Hearings before the Ninety-Second Congress, first session, U. S. House of Representatives, Committee on science and Aetronautics. subcomiltee on Energy, 371

Geothermal energy. Hearing before the subcommttee on energy of the Comittee on Selence and Astronautics, United States House of Representatl ves, MInety-Thlrd Congress. First Seselon on H.R. 8628, H.R. 9658 , September 11,13 , and $18,1973,379$

Dversight hearings on Public Law 93-410: the Geothernal Energy Rescerch, Development and Demonstration fet of 1974. Hearling before the Subcommittee on Energy Research, Development and Demonstration of the Committes on Science and Technology, Uis. House of Representatives, NInety-Fourth Congress, Second Session (Definition Report, ERDA-86), 103

Public hearing on geothe rmal energy and asooclated ineral resources, 475

Sente Judiciery Comittee HB 2040: April 30, 1975 , Oregon, 172

GEOTHERMAL ENERGY/LAWS

Development of geothermal laws and regulations, 302

Geothermal steam Act of 1970. Publlc Law 91-581. senate Res. 368,91 st Congress, December 24, 1970, 391

GEOTHERMAL ENERGY/LEGAL ASPECTS

California publie utilities commission. 146

Compendium of firet day papers presented at the firet Conference of the Geothernal Resources Councll, El Conference of the Geothermal Reso

Decision statement of secretery of Interior on geothermal resources program, 267

Federal tax polfey and geothermal energy development, 331

Geotheraal energy resources (Group position paper, 3 subgroup papers, and 1 review paper), 156 (CONF-750720)

Geothermal energy and its uses: technical, economic, envi ronmental, and legal espects, 110

Geotheral energy and the law, I. The federal lands anagement program, 224

Geotheraal energy: en Industry eppralsal, 232

Geothernal energy exploration, research and development. Senate report No. 93-849, 261

Geothermal: the proble of definition, 338

Geothermal resources leasing and operations on public, acquired, and withdraun lands. II, 423

Impact of ctate and federal lay on development of geotheraal resources in Texes, 299

Institut Ional and environmental aspects of geothermal energy development, 1

Institutional and environnentel aspects of geothermal energy development. 92

Inotitutional barpiers to geotheral : energy development.
Second report of the Insti tutlonal Barrier Panel to the Geothermal Advisory Councll, 134

Institutional, business, and financial aspects of the geothermal energy Industry, 252

Interrelat lonship between Federal, state and Local Regulatory Agencles (For exploration and exploitation of US geotherinal resources), 355

Introduction and legal overview of geothermal resources, 10

Law and geothermal development in New Zealand, 116

Law needed for geothermal energy, 268

Legal and institutional factors. Geothermal research atudy in the Salton Sea region of Calffornia, 233

Legal and polley aspects of geotheraal resource development, 398

Legal aspects of the utilizetion of geothermal heat, 75

Legal ospects of geothermal energy developaent, 126

Legal isaues in the development of geopressured-

geothermal resources of Texas and Loulsiana Gulf coast, 81 (CONF-760222-P5)

Legal problems of the geothermal industry, 469

Maxlmua and timely commerclal development of domest le geothermal energy, 179

Reich, A.E. et al. vs Commissioner of Internal Revenue and G.D. Rowan et al. us Commlssloner of Internal Revenue. U.S. Court of Appeals, Ninth circult. January 21, 1972 (Judiclel interpretation of IRS tax regulations relative to depietion allowance for geotheraal well drilling and development; 26 CFR 1. $263(\mathrm{c}), 1.611(\mathrm{a})$, and $1.613(\mathrm{~b})), 416$

state, federal lawnokers welgh geothermal leasing, 459

Sumary and concluding rearks, 24

Summary gulde to the institutional problens confronting the geothermal energy Industry, 283

United states law as it affects geothermal development, 115

United states of America va Union 011 Company of Callfornia. U.S. District Court, N.D. California Clv. No. 72-1866 GBH (Ownership rights of geothermal steam and resources from publle land leases; Stock Ralsing Homestead Act), 389

GEOTHERMAL ENERGY/LEGISLAT ION

Federal Geothermal Stean Act of 1970: Public Law 91-581, 344

Federal government leasing and operating regulations and environmental Impact itatements, 414

Free electriclty; plan to get more energy from heat Inside Earth moves forward a bit (Geothermal stean Act of 1970 ), 442

Geothermal Energy Research, Development, and

Demonatration Act of 1974, 167 (JPL-5040-6(Vol.3))

Geotherael Energy Research, Dovelopeent, and

Demonstration Act of 1974. Oversight hearings: loan guaranties. Hearings before the Subcomittes on Energy Research, Development, and Denonstration of the Committee on Science and Technology, U.S. House of Representatives, Ninety-Fourth Congress, First session, 207

Geotheraal laws and regulations In the western United States, 296

Geothermal Energy Researeh, Development, and Comerclal Demonstration Act of 1973; Geothermal Energy Research, Development, and Demonstration Act of 1974. Hearlings before the Subcomiltee on Energy of the Comalttee on Science and Astronautics, U.S. House of Representatives, Ninety-Thi rd Congress, second sesal on on H.R.11212 and H.R.14172, 300

Geothermal resources, present and future demand for power, and legialation In the tate of Wyoning, 410

Institutional, business, and financlal epects of the geothermal energy induetry (abstract), 257

Maximu and tialy commercial development of domest ic geotheral energy, 179

Packwood geotheraal bill (Senate Blll 8. 3392), 259

Public and geology-related leglalation in California, $1968-1972,381$

Report to the Congress. Problems in Identifying developing, and using geothermal resources, 189 (TID26866)

Research, development, and the energy crisls. Hearlings held November 20, 1973, 383

Review of ome of the legal problems in geothermal development, 413

Teras, conditions, standards, and application procedures for Initial geothermal development: Imperial County, Call fornta, 351

U.S. Energy Resources Development Administration: Geothermal loan Guaranty Program, 228

Ultinate future of the geothermal energy lar, 286

United States goothermal legislation and environmental Iapact lor leasing, 390

GEOTHERMAL ENERGY/MARKET

Geothermal energy: an Industry apprainal, 232

GETHERMAL ENERGY/MEETINGS

Afternoon General seselon, Frlday, 11 May 1973 (Natlonal Conference on Geothermal Energy, Palm Springs, Callfornta), 341

Compendiua of lirst day papers presented at the first Conference of the Geotherasl Resources Councll, El Centro, Callfornla, Fob 1972, 412

DInner Seselon. Thureday, 10 May 1973 (Natlonal Conference on Geotheraal Energy. Pall Springs, 
California), 339

FInancial aspects of geothermal resources development, San Francisco, Calf fornia, October 23-24, 1975, 226 Geothermal Resources Development Insti tute conference, Salt Lake City, Utah, January 27-28, 1977,9

proceedings of the geothermal power development conference, Univeraity of California, Berkeley, June $18,1974,271$ (LBL-3099)

Proceedings: national conference on geothermal energy. Pali Springs, Californta, May 10-11, 1973. Volume II, 335 (NSF/RA/N-73-117(Vol . 2))

Susanville Geothermal Energy Project. Workshop proceedings final technical report, 40 (SAN-1077-4) GEOTHERMAL ENERGY/PATENTS

Sumary of ERDA patent policy relevant to geotheraal energy, 165 (JPL-5040-6(Vol.3))

GEOTHERMAL ENERGY/PLANNING

Definition of an Institutional structure (Susanville Geothermal Energy Project), 35 (SAN-1077-4)

Development of the Nation's geothermal energy resources. II, 154

Econonic and engineering lapllcations of the Project Independence 1985 geotheral energy output goal and the associated sensitivity analysis, 96

Electrle utilities, 163 (JPL-5040-6(Vol.3))

ERDA's geothermal $R$ and D program, 102

Geothermal: as we see it today, 253

Longer-range technological potentials for energy development: an assessment of the prospects in new energy technology, 405

Program definition for the development of geotheras energy. Volume $I$. Background and program definition summary, 159 (JPL-5040-6(Vol .1))

Program definition for the development of geothermal energy. Volume III. Appendixes, 161 (JPL-5040-6(Vol.3 ))

Susanville Geothermal Utillty Systen, 41 (SAN-1077-4) GEOTHERMAL ENERGY/POLLUTION REGULATIONS

Geothermal Environmental Advisory Panel. Firgt annual report, June 1, 1974-June 30, 1975 (Preparation of guldel ines for industry compliance with environental monitoring), 225

GEOTHERMAL ENERGY/POWER POTENTIAL

Dinner Session, Thursday, 10 May 1973 (National Conference on Geothermal Energy, Palm Springs, California), 339

Earth's heat tupped for geothermal power development, 420

Geothermal energy: an industry appralsal, 69

Geothermal resources. Hearings before the subconnittee on Water and Power Resources of the Comiltee on Interior and Insular Affalrs, United states Senate, Ninety-Third Congress, First Session on the potential for the production of power from geothermal resources, 284

Luncheon Session, Thursday, 10 May 1973 (Natlonal Conference on Geotheral Energy, Pall Springs, Callf.), 340

Potential national benefits of geothermal electrical energy production from hydrothermal resources in the Uest, 97

Potential for energy production fron geothermal resources. Report of the Subcomittee on Water and Power Resources, Committee on Interior and Insular Affairs, Ninety-Third Congress, First Session, December 1973, 378

Technology forecast of United states geothermal energy resource development, 111

GEOTHERMAL ENERGY/PROJECT INDEPENDENCE

Maxi gur and timely conmercial development of domestic geothermal energy, 179

GEOTHERMAL ENERGY/PUBLIC RELATIONS

Public opinion concerning geothermal development in Lake County, California, 65 (LBL-4447)

Public opinion in Cobb Velley concerning geotherad development in Lake County, California, 50 (LBL-5204)

GEOTHERHAL ENERGY/REGULATIONS

Callfornia public utilities comission. 146

Callfornia laws for the conservation of geotheraal energy, an act to amend the heading of Chapter 4, and to add to Chapter 3, Division 3 , of the Public Resources Code, reliting to geothermal resources, 463

Callfornia laws for the conservation of geotheraal energy (Chapter 1483, Statutes of 1965), an act to add Chapter 4, Division 3, to the Public Resources Code, relating to geothermal energy and associated resources, relat

Development of geotherwal laws and regulations, 302

Geothermal resource development process, 47 (JPL-504025(Rev.A)(App.))

Geothernal laws and regulations in the western United States, 296

Institutional barriers to geothermal energy developent. A report by the Institutional Barrier Panel to the Geothermal Advisory Council, 135

Inetitutional, business, and finanelal opects of the geothermal energy industry (abstract), 257

Regulatory, planning and policy asecta of geothermal onergy development in Imperlal County. California

Rotorua City (New Zeeland) regulations on geothermal energy, 265

GEOTHERMAL ENERGY/RESEARCH PROGRAKS

Cooperative efforts by Induetry and government to develop geothermal resources, 241 (NSF/RA/N-74-159) Development of the Nation's geothermal energy resources. II, 154

ERDA's geothermal $R$ and $D$ program, 102

ERDA authorization. Part II. 1976 and transtition period: geothermal. Hearings before the Subcomittee on Energy Research, Development, and Demonstration of the Comittee on Science and Technology, U.S. House of Representatives, NinetyFourth Congress, First Session, 203

Geothermal energy program. Subpanel report VIII used in preparing the AEC Chairman's report to the President, 325 (UASH-1281-8)

Geothermal energy development. Hearing before the Subcommittee on Energy Research and Water Resources of the Committee on Interlor and Insular Affalrs, United states Senate, Ninety-Fourth Congress, First Session, 217

Geothermal Energy Research, Development, and Demonstration Act of 1974. Submitted by Mr. Teague, Committee on Science and Astronautlcs, to the House of Representatives, Ninety-Third Congress, Second Session, 274

Geothermal Energy Researeh, Development, and Comerclal Demonstration Act of 1973; Geotheraal Energy Research, Development, and Demonstration Act of 1974. Hearings before the Subcomittee on Energy of the Comittes on Science and Astronautics, U.S. House of

Representatives, Ninety-Third Congress, Second session on H.R.11212 and H.R.14172, 300

Geothermal energy. Hearings before the Ninety-second Congress, FIrst Session, U. S. House of

Representatives, Committee on Sclence and Astronautics, Subcomittee on Energy, 371

Geothermal research, 399

Geotheraal power in California, a response to Senate Resolution No. 138, relating to the use of geothermal power for the transportation of water over the Techachap Hountains, 468

Government activity report on geothermal energy in Japan, 112

Highlights of energy related leglslation in the 93rd Congress. Prepared at the request of Henry $n$. Jackson. Chairman, Comittee on Interior and Insular Affalrs, United States Senate pursuant to S.Res. 45, 215

Laws, regulations, and social constraints to the development of geothermal energy, 139

NSF/RANN FY 1975 program for geothermal resources research and technology, 187

Project Independence. Final task force report: geothermal energy, 250 (NP-20944)

Research, development, and the energy erisis. Hearing before the Subcomittee on Energy of the Comaittee on Sclence and Astronautics, U.S. House of Representatives, Ninety-Third Congress, First Sesion, November $20,1973,272$

Research and devel opment, 46 (JPL-5040-25(Rev.A)(App.))

S. 564, to establish a five-year geothermal research program; text; statement, 427

S.1283, Natlonal Energy Research and Development Pollcy Act of 1973,359

The potential for energy production from geotheras resources: Report of the Subcomittec on Water and Power Resources, Committee on Interior and Insular Affairs, United States Senate, Ninety-Third Congress, First Session; 324

GEOTHERHAL ENERGY/RESERUES

Relch case: economic implications of depletion allowances, 222

\section{GEOTHERMAL ENERGY/REVIEUS}

1974: the geotheraal year in retrospect (Developaent problems and out look), 182

Ex-Assistant Adininistretor looks back on ERDA's lat year and ahead to 2nd (Intervi ew with John M. Teem, former $A A$ for solar, geothermal, and advanced energy oyetems), 60

Geotheral energy: an Industry appraisal, 69

Geothermal energy: an industiry appraisal, 76

Geothermal energy, 90

Geotheral energy, 94

Geothermal world directory (1973), 376

Geothermal energy, its future and econonles, 419

Report to the Congress. Problems in identifying. developing, and using geothermal resources, 189 (TID26866 )

Solar and geotheraal energy: new competition for the atom, 248

Some reflections on the history of the United Nations and U.s. Government geothermal activities, 177

GEOTHERMAL ENERGY/SOCIAL IMPACT

OpInion bout geothermal development in Imperial County. Calleornla, 1976. Final report, 7

GOTHERMAL ENERGY/SOCIO-ECONOMIC FACTORS

Definition of an institutional structure (susanville Geothermal Energy Project), 35 ( 8 AN-1077-4)

Economfe and coclal aspecto of geothermal eneroy resource development, 128

Goothermal development policy for an isolated state: the cate of Hawali, 119

Public opinion concerning geothermal development in Lake County, Callfornia, 65 (LBL-4447)

Soclal inplications that nay arise with future geotheraal use, 125 
Socio-econonic model, 38 (SAN-1077-4)

Susanvilie project requirements, 37 (SAN-1077-4)

Technical asestment of the impact of geopressure

development In the Corpus Christ I area of Texas, 120

GEOTHERMAL ENERGY/SYSTEMS ANALYSIS

Energy analyst and publ ic poltey, 155

GEOTHERMAL ENERGY/TAXES

Constraints on geotheraal developnent: tax and beyond, 19

Development of geothermal laws and regulations, 302

Relch case: conomic Implications of depletion 11 lowances, 222

GEOTHERMAL ENERGY/TECHHOLOGY ASSESSMENT

A technology assessment of geotheraal energy resource development, 184 (PB-246241)

Economic and engineering iaplications of the project Independence 1985 geotheraal energy output goa $i$ and the ssociated sensitivity analysis, 96

Geothermal energy and its uses: technical, economic, environeental, and legal apects, 110

Technology forecast of United States geothermal energy resource development, 111

GEOTHERMAL ENERGY IUSES

Mational program definition study for the non-electrical ut llization of geothermal energy, 173 (ANCR-1214) Present plans for ut llization of geotherael energy, 45 (JPL-5040-25(Rev.A) (APP.))

Soclal implications ay arise with future geothermal usage, 93

GEOTHERMAL ENERGY/WATER REQUIREMENTS

Vater conflicts from the vieupoint of regulator, 16 GEOTHERMAL ENERGY CONUERSION/EQUIPMENT

Guidelines relative to pipelines and curface production equipment and to production and royalty measurement, equipment, and testing procedures (Order Nos. 6 and 7 ), 30

GEOTHERMAL ENERGY CONVERSION/GOVERNMENT POLICIES

Geothermal resources. Parts I and II. Hearings before the Subcomittee on Water and Power Resources of the Comittee on Interior and Insular Affaira, United states Senate, Ninety-Third Congress, First Session, Stat

GEOTHERMAL ENERGY CONUERSION/PLANNING

Characteristles of $n$ ine communities considering geothermal ut1lizetion, 39 (SAN-1077-4)

GEOTHERMAL ENERGY R D AND D ACT

Geothermal Energy Research, Development, and

Demonstration Act of 1974, 167 (JPL-5040-6(Vol.3))

Geothermal Energy Research, Development, and Demonstration Act of 1974. Subilted by Mr. Teague, Coanittec on Science and Astronautics, to the House of Representetives, Ninety-Third Congress, Second Session, 27

GEOTHERMAL ENERGY R D AND D ACT/HEARINGS

Geothermal Energy Research, Development, and

Demonstration Act of 1974. Overslght hearings: loan guaranties. Hearings before the Subeomal ttes on Energy Research. Development, and Demongtration of the Committee on Science and Technology, U.S. House of Representatives, Ninety-Fourth Congress, First session, 207

Geothermal Energy Research, Development, and Commerclal Dewonstration Act of 1973; Geothermal Energy Research, Development, and Demonstration het of 1974. Hearings before the subcomittee on Energy of the Committee on Sclence and Astronatics, U.S. House of

Representatives, Ninety-Third Congress, second sesston Representatives, Ninety-Third Con
on $H . R .11212$ and $H . R .14172,300$

Oversight hearings on Public Law 93-410: the Geothermal Energy Research, Developnent and Demonstration Act of 1974. Hearing before the Subcomitte on Energy Research, Development and Demonstration of the Comblttee on Solence and Technology, U.S. House of Representatives. Ninety-Fourth Congress, second Session (Definition Report, ERDA-86), 103

GEOTHERMAL EXPLORATION

Geothermal energy development,

Geothermal resource characteristics, exploration considerations, and property acquileition techniques, 251

Geothermal energy exploration, research and development. Senate report No. $93-849,261$

Leasing and exploration, 162 (JPL-5040-6(Vol .3))

GEOTHERIAL EXPLORATION/BIBLIOGRAPHIES

Geothermal resources: exploration and exploitation. A bI bl lography, 43 (TID-3354-R1)

Geothermal energy. Vol ume 2. Search period covered: May 1975-April 1976. Citations from the NTIS Data Base, 137

Geothermal energy, Volume 1. Search perlod covered: 1970-1974. Citations from the Englneering Index Data Base

GEOTHERMÁL EXPLORATION/BUDGETS

Geothermal exploration: atrategy and budgeting, 181

GEOTHERHAL EXPLORATION/ECONOMICS

Ecomonica of geotheral exploration, 312

Geothernal resource characteristlcs, exploration considerations, and property acquisition techniques, 270 (CONF-741145-3)

Geotheral exploration and development in the United states: ax analysis under the Internal revenue code, 117

status of econonics and financing geotheraal energy power production, 227
GEOTHERMAL EXPLORATION/ENUIRONMENTAL EFFECTS

Geothermal Envi ronmental Advimory Panel. Firat annual report, June 1, 1974-June 30, 1975 (Preparation of guldelines for industry compliance with environmental monit oring ), 225

Posslble confilct between the interests of tourlsa and geothermal power development, 127

GEOTHERMAL EXPLORATION/ENVIRONMENTAL IMPACTS

Environmental overview of geothermal resources development, 22

Geothermal Envi ronmental Advisory Panel. Second annual report, July 1, 1975-June 30, 1976, 136

Summer Lake Babin geotheraal leasing: Environnental Analyais Record, 51 (NP-21256)

EOTHERMAL EXPLORATION/FINANCIAL INCENT IVES

Geothermal exploration and development In the United States: a tax analysis under the Internal revenue code, 117

Geothermal exploration and development in the United states: tax analysis under the Internal Revenue Code, 230

Relch, A.E. et al us Commlssioner of Internal Revenue and G.D. Rowan t al. vs Comalssloner of Internal Revenue. U.S. Court of Appeals, Ninth circult. January 21, 1972 (Judiclal interpretation of IRS tax regulations relative to depletion allowance for geotheral well drilling and development; 26 CFR 1. $263(\mathrm{c}), 1.611(\mathrm{a})$, and $1.613(\mathrm{~b})), 416$

Relch, Arthur E. And Carolyn C. Relch ys Commsslon of Internal Revenue, U.S. Tax Court, July 31, 1969 (Depletion allowances for intangible costs of drilling and developing geothermal stean weils), 456

GEOTHERMAL EXPLORATION/FINANCING

Formation, funding, and development of a small

exploration company, 231

Geothermal tax considerations and shelters (Impleaentation of IRS regulations 26 CFR 613; 704; $731 ; 741$ and 752 ), 229

Geothermal resources research and technology, 245

Recent developments in the taxation of geothermal exploration, 196

Role of municipalities in geothermal resource development, 14

GEOTHERMAL EXPLORATION/GOVERNMENT POLICIES

Some issues regarding regulatory policy, political participation, and social lapilcations of geothermal resource development in the. Imperial Valley, 142 GEOTHERMAL EXPLORATION/LAWS

Law needed for geothermal energy, 268

GEOTHERHAL EXPLORATION/LEGAL ASPECTS

Flow chart of critical path in geotheral exploration, 343

Geothermal resource characteristics, exploration considerations, and property acquisftion techniques, 270 (CDNF-741145-3)

Geothermal resources operational Order No. 1 : exploratory operations, 234

Geothermal exploration on public lands: when and under what conditions (USA), 337

Interrelationship between federal, state, and local regulatory agencies on the development of the geothermal resource in California, 342

Legal probleas of the geothermal industry, 469

Some lasues regarding regulatory policy, political participation, and social impilcations of geothermal resource development in the Imperial valley, 142 GEOTHERMAL EXPLORATION/LEGISLATION

Geothermal resources, present and future demand for power and legislation in the State of Wyoning. Public information serles 1,67 (NP-21229)

H.R. 14801 , to promote the exploration and development of geothermal resources through cooperation between the federel government and private enterprise: text. 395

Proposed rule making: geothermal resources - leasing on public; acquired and wthdrawn lands; revision of proposed rule, 345

Recent developments in the taxation of geotheral exploration, 310

GEOTHERMAL EXPLORATION/LICENSING

Overviow of the California permitting process, 23

GOTHERMAL EXPLORATION/ORGANIZING

Formation, funding, and development or a small exploration company, 231

GEOTHERMAL EXPLORATION/PLANNING

Geothermal resources research and technology, 245

Program definition for the development of geothermal

energy. Volume III. Appendixes, 161 (JPL-5040-6(Vol. ))

TOTHERMAL EXPLORATION/POOLING

Unitization for geotheral resources: united we save, 17 GEOTHERMAL EXPLORATION/REGULATIONS

Flow chart of critical path in geotheral exploration, 343

Geothermal leasing program (draft environmental impact statement), 431 (PD-218830)

Impact of state and federal iaw on development of geothermal resources in Texas. Project $L / R-9$, final report, 254 (NSF-RA-N-74-244)

Interrelationship between rederal, state, and local regulatory agencies on the development of the geothermal resource in California, 342 
Laws, regulations, and social constrainta to the development of geothermal energy, 139

Overview of the Callfornia peralting process, 23

GEOTHERMAL EXPLORATION/SOCIO-ECONOMIC FACTORS

Possible conflict between the Interests of tourlsm and geo theraal power devel opment, 127

GEOTHERKAL EXPLORATION/TAX SHELTERS

Geothermal tax consferations and shelters

(Implementation of IRS requlations 26 CFR 613; 704 ; 731 ; 741 and 752 ), 229

GEOTHERMAL EXPLORATION/TAXES

Geotheraal exploration and development in the United States: tax analyal under the internel revenue code, 117

Geothermal exploration and development in the United States: a tax analysis under the Internal Revenue Code, 230

Recent developments in the taxation of geothermal exploration, 196

Recent developmenta In the taxation of geothermal exploration, 310

Recent developments in the taxation of geothermal exploration, 485

Reducing the risks in geothermal exploration: a tax update, 180

Relch, A.E. ot al. vs Comissioner of Internal Revenue and G.D. Rowan et al. va Commisaloner of Interna Revenue. U.S. Court of Appeals, Ninth circuit. January 21, 1972 (Judiclal interpretation of IRS tax regulations relative to depletion allowance for geothermal well drilling and development: 26 CFR 1. $263(\mathrm{c}), 1.611(\mathrm{a})$, and $1.613(\mathrm{~b})), 416$

Tax treatment of exploring and developing geothermal resources, 334

GEOTHERMAL FIELDS

SEe al so EAST MESA GEOTHERMAL FIELD

HEBER GEDTHERMAL FIELD

SALTON SEA GEOTHERMAL FIELD

GEOTHERMAL FIELDS/BI BLIOGRAPHIES

Geothermal energy. Volume 1. Search period covered 1970-1974. Citations from the Englneering Index Data Base, 138

GEOTHERKAL FIELDS/ENVIRONMENTAL IMPACTS

Geothermal resources operational Order No. 4: general environmental protection requil rements, 237

GEOTHERMAL FIELDS/LAND LEASING

Comments on draft environmental Inpact statement for the federal geothermal leasing programs, 436

Environmental impact statement for the geothermal leasing program; draft, 422

Geothermal stean leasing; hearings before subcomittee on Minerala, Materlala and Fuels on $S .23$ and $S .912$, Ma rch 12-22, 1970,465

State, federal lawmakers weigh geothermal leasing, 459

US policy on land leasing for geothermal energy developmen $t, 353$

GEOTHERMAL FIELDS/PI PELINES

Geothermal resources operational Order No. 6: plpelines and surface production facllities, 26

GEOTHERMAL FIELDS/HATER RIGHTS

Water conflicts from the viewpoint of agulator, 16 GEDTHERMAL FLUIDS SEe a 1 so NATURAL STEAM

GEOTHERMAL FLUIDS/BIBLIOGRAPHIES

Geothermal energy. Volune 2. Search perlod covered May 1975-April 1976. Citations fros the NTIS Data Base, 137

GEOTHERMAL FLUIDS/CONTRACTS

Geothermal sales contracts, 21

GEOTHERHAL FLUIDS/ENVIRONMENTAL IMPACTS

Geothermal resources of the Texas Gulf Coast: environmental concerns arl ising from the production and disposal of geotheraal waters, 83 (CONF-760222-P5)

GEOTHERMAL FLUIDS/WASTE DISPOSAL

Geothermal resources of the Texas Gulf Coast: environmental concerns arising from the production and disposal of geotheraal waters, 83 (CONF-760222-P5)

GEOTHERMAL HEATING/GEOTHERMAL RESOURCES

Geothermal resources. Parts I and II. Hearings before the Subcommittee on Uater and Power Resources of the Comittee on Interior and Insular Arfairs, United states Senate, Ninety-Third Congress, First Session, 297

GEOTHERMAL HEATING/GDVERNMENT POLICIES

Geothermal resources. Parts I and II. Hearings before the Subcommittee on Water and Power Resources of the Comittee on Interior and Insular Afrairs, United States Senate, Minety-Third Congress, First Session. 297

GEOTHERMAL INDUSTRY/REVIEWS

Geotherad energy: an industry appralsal, 76 GEOT HERMAL POWER PLANTS

Energy. from geothermal resources. Report prepared for the Subcomittee on Energy of the Committee on Sclence and Astronautics, U.S. House of Representatives, and Astronautics, U.S. House of Representats

Geothermal energy. Hearings before the Ninety-Second Congress, First Sasslon, U. S. House of

Representatives, Comalttee on Sclence and Astronautics, Subcomittee on Energy, 371

Geothermal power, 374

GEOTHERMAL POUER PLANTS/ECONOAICS
Utility particf pation in a geothereal energy source, 293 GOTHERMAL POWER PLANTS/ENVIRONHENTAL ImPACTS

Environmentel Impact of geothermal power plant (Walrakel geothermal field), 188

GEOTHERMAL POWER PLANTS/FINAKCING

Electric utilities, 163 (JPL-5040-6(Vol.3))

Utility participation in a geothermal energy source, 293 GEOTHERMAL POWER PLANTS/HEARINGS

Union 0il testimony: Geysers Power Plant 12 hearing (Californla Public Utilities Complission), 256

GEOTHERMAL POWER PLANTS/LEGAL ASPECTS

Flow chart of critical path in geotheral exploration, $\mathbf{3 4 3}$

Interrelationship between federal, state, and local regulatory agencles on the development of the geothermal resource in California, 342

GEOTHERHAL POWER PLANTS/OPERATION

PGandE's geothermal power plant in Callfornia: the Geysers, 307

GEOTHERMAL POWER PLANTS/POLER GENERATION

California public utilities comission., 146

PGandE's geothermal power plant in Californie: the Geysers, 307

GEOTHERMAL POWER PLANTS/POWER POTENTIAL

Geothermal power expangion in Callfornla, 266

GEOTHERMAL POWER PLANTS/REGULATIONS

Flow chart of critical path in geothermal exploration, 343

Geothermal leasing program (dratt environmental Iapect statement), 431 (PD-218830)

Interrelationship between rederal, state, and local regulatory agencies on the development of the geothermal resource in Callfornia, 342

GEOTHERMAL RESQURCES

Energy Irom geotheral resources. Report prepared for the subcomittee on Energy of the Comittee on Science and Astronautics, U.S. House of Representatives, Ninety-Third Congress, Second Session, 289

Geothermal energy development, 2

Geotherasl resource characteristics, exploration considerations, and property acquisition techniques. 251

Geothermal world directory, 401

Indlans ceutious on devel opment, 32

Program definition for the development of geotheral energy. Volume I. Background and program definition summary, 159 (JPL-5040-6(Vol .1))

Progran definition for the development of geothermal energy. Volume II. Program definition development rationale and subprogram descriptions, 160 (JPL-50406(Vol.2))

Progras defint tion for the development of geothermal energy. Volume III, Appendixes, 161 (JPL-5040-6( Vol ))

GEOTHERMAL RESOURCES/AVAILABILITY

Introduction: the energy outlook, 377

GEOTHERMAL RESDURCES/BIBLIDGRAPHIES

Geothermal resources: exploration and exploftation. bibliography, 43 (TID-3354-RI)

Geothermal energy. Volume 1. Search period covered: 1970-1974. Citations from the Engineering Index Date Base, 138

GEOTHERMAL RESDURCES/BY-PRODUCTS

Geothermal resources operational Order No. 7 : production and royalty measurement, equipment, and testing procedures, 27

GEOTHERMAL RESOURCES/CASE LAH

Geothermal resources: water and other conflicts encountered by the developer. An alternative energy source which is "gathering steam't, 15

GEOTHERMAL RESDURCES/CONTRACTS

Geotheral resources Jolnt ventures, 13

GEOTHERMAL RESOURCES/COST BENEFIT ANALYSIS

Benefits and costs to landouners from geothermal resource lease and development, 140

GEOTHERMAL RESOURCES/DEPLETION ALLOWANCES

Geothermal exploration and development in the United States: a tax analysis under the Internal Revenue Code, 230

Incone taxation of geothermal resources, 20

GEOTHERMAL RESOURCES/ECONOMIC DEVELOPHENT

Inst Itut lonal and environmental problens in geothermal resource development, 243 (NSF/RA/N-74-159)

Multi-purpose geothermal resource development: an overview, 91

Multipurpose geothermal resource development: an overview, 114

Project Independence. Final task force report: geothermal energy, 250 (NP-20944)

Public interest vs. private partisenship in geothernal development, 178

Role of municipalities in geothermal resource developaent, 14

GEOTHERMAL RESOURCES/ECONOMIC IMPACT

Economic iapact of geotheraal energy development, 5 GEOTHERMAL RESOURCES/ECONOKICS

Geothermal resource characteristlcs, exploration considerations, and property cquisition techniques, 270 ( CDNF-741145-3)

Geothermal resources in Callfornta, 470

GEOTHERKAL RESOURCES/ENERGY POLICY

The potentlal for energy production from geothermal resources: Report of the Subcomittee on Hater and Power Resources, Committee on Interlor and Insular 

Afralrs, United states Senate, Ninety-Third Congress,

GEOTHERMAL RESOURCES/ENERGY SOURCE DEUELDPMENT

Benefits of stimulating geothermal energy development

with tax and research subsidies, 143

Geothermal energy resources (Group position paper, 3 subgroup papers, and 1 revilew paper), 156 (CONF-750720).

Huitiactor analysis of the impact of geothermal development on the economy of Imperial County, California, 26

GEOTHERMAL RESOURCES/ENUIRONMENTAL EFFECTS

Final environmental statement for the geothermal leasing program. Volune 1,365

Final environmental statement for the geothermal leasing program. Volume II, 366

Geotheral resources: water and other confliets encountered by the developer. An alternative energy source which is "'gathering atean"', 15

Geotherimal resources operational (GRO) Order No. 4 for central and western reglons, 168

Proceedings of the workshop on environmental aspects of geothermal resources development, 20-22 Septeaber 1974, 315

Some issues regarding regulatory pollcy, political participation, and aoclal implicatlons of geothermal resource development in the Imperial Valley. 74 (NP21381)

The potential for energy production from geothermal resources: Report of the Subcomittee on Water and Power Resources, Connlttee on Interior and Insular Affalrs, Unlted States Senate, Ninety-Third Congress, First Session, 324

GEOTHERMAL RESOURCES /ENU IRONHENTAL IMPACT STATEMENTS

EIR's: truth and consequences (Legislation, tatus, and recommendations for geothermal development), 306 GEOTHERMAL RESOURCES/ENUIRONHENTAL IHPACTS

Benefits and costs to landowners from geothermal resource lease and development, 140

Economle impact of geothermal energy development, 5

Geothermal resources operational Order No. 4: general environmental protection requirements, 237

GEOTHERMAL RESOURCES/EXPLOITATION

Afternoon General Seasion, Friday, 11 Kay 1973 (National Conference on Geothermal Energy. Palm Sprlngs, California), 341

Geotheral resource development; report to accompany $s$. 368,445

Property systems in geothermal resources: a critique and recommendat i ons, 118

GEOTHERMAL RESOURCES/FIHANCING

Geothermal Federal loan guarantee prograa (Federal Reg(ster), 148

GEOTHERMAL RESOURCES/GOVERMMENT POLICIES

Appendix A: governance of geothermal energy development, 48 (JPL-5040-25(Rev.A) (App.))

Development of geotheriaal resources and the 1970

Geothermal stean Act: law in search of definltion, 318

Geothermal energy: legal problems of resource development, 105

Geotheral resources: legal and tax conslderations, 291

Geothermal resources. Parts I and II. Hearings before the Subcomittee on Vater and Power Resources of the Comittec on Interlor and Insular Affalrs, United states Senate, Ninety-Third Congress, First session, 297

Hearing on the ownership of geotherwal steaw underlying Geysers. Geothernal Kinetics Inc., plaintiff, vs Union Oil Company of Callfornia, defendants, May 28, 1976, 33

Prelininary report on legal and public polley setting for geotheraal resource development in Hawali, 279

Regulatory aspects of geothermal energy development in the Salton Sea/Imperial Valley Area, 186 (UCID-16807)

state polley constderations for geothermal devolopment In Hawa 11, 171

Why public policy must support geothermal development, 309

GEOT HERMAL RESDURCES/HEARINGS

Federal Energy Adminietration hearing on vestern reglonal resource development, 246

Geothermal energy: potentially the lest's ajoj energy resource (Project Independence hearing $\$$ ), 247

Geothernal resources. Hearings before the subcomalttee on Uater and Power Resources of the Committee on on Uater and Power Resources of the Comittes on Interfor and Insular Afrairs, United states Senate, for the production of power from geothermal pesources, 284

Geothermal resources (Potential for production or electriclty and heat (n Idaho), 382

Geothermal energy resources and research. Hearings before the Comittee on Interlor and Insular Affairs, United states Senate, pursuant to $s$. Res. 45, a national fuele and energy pollcy study, Ninety-second congress, Second session on the role of geothermal energy resources in our nation's future energy econony June 15 and $22,1972,407$

Geothermal sclence and technology: natlonal program, 432

Hearing on the ownership of geotheral etean underlying Geysers. Geothermal Kinetics Ince, plalntiff, vs Union Dil Company of Callfornis, defendants, May 28, 1976, 33
Potential ror energy production from geotheraal resources. Report of the Subcomittee on Hater and Power Resources, Committee on Interior and Insular Affalrs, Ninety-Third Congress, First Session, Decenber 1973, 378

GEOTHERMAL RESOURCES/INCOME

Benefits and costs to landowners from geotheral resource lease and development, 140

Geothermal resources operational Order No. 7 : production and royalty weasurement, equipment, and testing procedures, 27

GEOTHERMAL RESOURCES/LAND LEASING

Callfornia's geothermal lands: a legal framework for resource development, 121

Environmental lapacts of geothermal resource development on comercial ariculture: a case study of land use contlict, 131

Environmental planning for the geothermal leasing progras on public lands, 285

Federal government leasing and operating regulations and envi ronmental impact statements, 414

Federal reguletions and lease terms and their regulationship to state laws and regulations, 303

Final environmental atatenent for the geothermal leasing program. Volume I. Pronulgation of leasing and operating regulations, 360 ( NP-20212)

Final environmental statement for the geothermal leasing program. Volume I, 365

Final environmental statement for the geotheral leasing progran. Volume II, 366

Final environmental tatement for the geothermal leasing program. Volume III, 367

Final environmental stement for the geothermal leasing program. Volume IV, 368

Geothermal Leasing Progran. Volume I. Promulgation of leasing and operating regulations. Final envi ronmental impact statoment, 326 (EIs-CA-73-1681-F1)

Geothermal Leasing Program. Volume III. Appendices A through H. Proposed geothermal, leasing, and operating regulat lons. Final environgental impact statement, 328 (EIS-CA-73-1681-F-3)

Geotheraal Leasing Program. Volume IV. Appendix I. Comments on draft impact atatement and proposed regulations. Final environmental impact tatement, 329 (EIS-CA-73-1681-F-4)

Geothermal resources, present and future demand for power and legislation In the state of Hyoning. Public information eries 1, 67 (NP-21229)

Geothermal Leasing Program, 396 (PB-208954)

Geothermal leasing program. (Supplement to draft dated 6 Det 1971, PB-203102-D), 397 (PB-208954)

Geothermal leasing program (draft environmental inpact statement), 431 (PD-218830)

Geothermal tean act of 1970 (exploitation and development of geothermal steam resources), 447 (PD218830 )

Geothermal stean act of 1965 (a bill to authorize the Secretary of the Interior to aake dieposition of geothermal stean and assoclated geothermal resources), 474 (PD-218830)

Geothermal leasing practlces, 12

Geotheral energy and the law. I. The federal lands managenent program, 224

Geotherael resources leasing: general, 320

Governmental leasing regulations, 290

Lease of federal geothermal energy: rocky roed (abstract), 34

Leasing and exploration, 162 (JPL-5040-6(Vol .3))

Leasing of Federal geothermal resources, 242 (NSF/RA/N74-159)

leasing on public, acquired and withdrawn lands; revision of proposed rule, 347

Legal, Institutional, and polltical problens in producing lectric power from geothermal resources in Callfornia, 144

Proposed rule making: geothermal resources - leasing on public, acquired and withdrawn lands; revistion of proposed rule, 345

Recent geothermal developnents in Colorado, 174

Report to the congress: problems in Identifying. devoloping, and using geotheraal resources, 190 (NP20694)

Role of public lands in geotheraal energy, 199 (CONF$750612-)$

Role of the state Lands DIvision In developing geothermal reaources in California, 70

Rules and regulationg releting to geothermal leases on Colorado state owned lands, 292

structure of the geothermal industry through 1974, 238

Sumer Lake Basin geothermal leasing: Environmental Analysts Record, 51 (NP-21256)

GEOTHERHAL RESOURCES/LAND POLLUTIÓN ABATEMENT

Geothermal resources operational Order. No. 2 : drilling, completion, and spacing of geothermal wells, 235

GEOTHERISAL RESOURCES/LAND RECLAMATION

Geotheraal energy lands out Ined, 461

GEOTHERMAL RESOURCES/LANDOWNER

Beneft ts and costs to landowners from geothernal

resource lease and development, 140

GEOTHERMAL RESOURCES/LAUS

Income taxation of geotheraal resources, 20 
Legal issues in the development of geopressured geotheral resources of Texas and Loul siana Gulf coast (Sumary) (Resource definitions in statutes of 15 states , 31

GEOTHERMAL RESOURCES/LEASES

Benefits and costs to landowners from geothermal resource lease and development, 140

Contents of geothermal lease: some suggestions, 87

Geothermal resources: leasing on public, acquired, and wi thdrawn lands, 321

Governmental leasing regulations, 290

GEOTHERHAL RESOURCES/LEGAL ASPECTS

Administrative requirements for development of geothermal resources, 157

Appendix B: administrative requirements for development of geothermal resources, 49 (JPL-5040-25(Rev.A) (APp.)) Callfornia's geothermal lands: a legal framework for resource development, 121

Callfornia geothermal resources: how well are we doing, 124

Classification of public lands valuable for geothermal steam and associated geothermal resources (Geothermal st eam act of 1970 ), 434

Development of geothermal resources and the 1970 Geothermal Steam Act: law in search of definition, 318

Energy fuel mineral resources of the public lands. Volume I. Master report: a study prepared for the Public Land Law Revieu Commission, 453

Evolution of oll and gas law, 481

Geothermal resource characteristics, exploration considerations, and property acquisition techniques. 270 (CONF-741145-3)

Geothermal leasing practices, 12

Geothermal resources joint ventures, 13

Geothermal resources: water and other conflicts encountered by the developer. An alternative energy source which is "gathering stean', 15

Geothermal resources operational Order No. 6: pipelines and surface production facilities, 26

Geothermal resources operational Drder No. 7 production and royal ty measurement, equipment, and testing procedures, 27

Geothermal energy: iegal problems of resource development, 105

Geothermal rights and problems of legislation in Japan, 122

Geothermal resources operational Order No. 2: drilling, completion, and spacing of geothermal vells, 235

Geothermal resources operational Order No. 3: plugging and abandonment of wells, 236

Geothermal resources operational Drder No. 4: general environmental protection requirements, 237

Geothermal resources legal and tax considerations, 263

Geothermal resources: legal and tax considerations, 291

Geothermal exploration on public lands: when and under what conditions (USA), 337

Geothermal stean and resources, 446

Geothermal stean poses ownership questions, 454

Internal Revenue Service Regulations (Mineral depletion allowances for tax purposes), 458

Law of Iceland as it affects geothermal development, 123

Legal, institutional, and political problems in

producing lectric power from geothermal resources in

Callfornia, 144

Legal issues in the development of geopressuredgeothermal resources of Texas and Loulsiana Gulf Coast, 81 ( CONF-760222-P5)

Legal issues in the development of geopressured geotheraal resources of Texas and Loulsiana Gulf Coast (Sumary) (Resource definitions in statutes of 15 states), 31

Hultipurpose geothermal resource development: an overview, 114

Ownership rights of geothermal resources in Sonoma County, Callfornia, 372

Property systems in geothermal resources: a critique and recommendations, 118

Sone issues regarding regulatory policy, political particlpation, and soclal iaplications of geothernal resource development in the Imperial Valley, 74 (NP21381)

Sumary guide to the institutional probleas confronting the geotheral energy Industry, 244 (CONF-741145-1)

Sumary of Section XII: legal and institutional aspects, 107

Tax treatment of exploring and developing geothermal resources, 334

GEOTHERMAL RESOURCES/LEGISLATION

Geothermal Stean Act of 1970: known geothermal

resources areas; partial list, 426

Authorizing the Secretary of the Interior to make disposition of geothermal stean and associated

geothermal resources report to accompany $S .368,444$

Callfornia public resources code: statutes pertaining to geothermal resources, 348

Disposition of geothermal stean - 1967, 464

Disposition of geotheral stean, 471

Geothermal stean act of 1970 (exploltation and development of geothermal stean resources), 447 (PD218830)

Geothermal resources: water and other conflicts encountered by the developer. An alternative energy source which 1 ' 'igathering steami', 15

Geothermal rights and problems of legisiation in Japan, 122

Geothermal energy: an Industry appraisal, 232

Geotheral resources - operations on public, acquired and withdrawn lands; notice of proposed rulemaking, 346 Geothermal steam Act of 1970; procedure to be followed in claining rights, 428

Geothermal resource development: report to accompany $S$. 368,445

Geothermal steam act of 1970. Exploitation and

development of geothermal steam resources, 446

Geothermal Steam Act of 1966 (S. 1674); memorandum of di sapproval, 14 Nov 1966,466

Geothermal steam, 467

H.R. 14801, to promote the exploration and development or geothermal resources through cooperation between the federal government and private enterprise; text, 395

Idaho Legislature, 354

Inplementing the federal geothermal stean act of 1970 , 429 (CONF-710571-)

Proposed rule making: geothermal resources - leasing on public, acquilred and withdrawn lands; revision or proposed rule, 345

Role of the State Lands Division in developing geothermal resources in Calf fornia, 70

s. Con. Res. 29, to express the sense of Congress that the Bureau of Reclamation should accelerate its Investigations of geothermal resources as a potential ajor new source of water supplies for the western United States; text; statement, 424

summary guide to the institutional problems confronting the geothermal energy industry, 244 (CONF-741145-1)

GEOTHERMAL RESOURCES/MANUALS

Geothermal world di rectory (1973), 376

GEOTHERMAL RESOURCES/MEASURING METHODS

Geothermal resources operational Order No, 7: production and royalty measurement, equipment, and testing procedures, 27

GEOTHERMAL RESOURCES /OWNERSHIP RIGHTS

Acquisition of geothermal rights: proposed methods, 478

Benefits and costs to landowners from geotheral resource lease and development, 140

Ownership rights of geothermal resources in Sonome County, Callfornta, 372

United States of America vs Union OIl Company of Callfornia. U.S. District Court, N.D. California Civ. No. 72-1866 GBH (Ownership rights of geothermal stean and resources from public land leases; Stock Ralsing Homestead Act), 389

GEOTHERMAL RESOURCES/PLANNING

Interdisciplinary planning for geothermal development at the county level, 99

GEOTHERMAL RESOURCES/POOLING

Unitization for geothermal resources: united we save, 17 GEOTHERMAL RESOURCES/PRODUCTIDN

Geothermal resources operational Order No. 6: pipelines and surface production facilities, 26

Geothermal resources operational Order No. 7 : production and royalty measurement, equipment, and testing procedures, 27

GEOTHERMAL RESOURCES/REGULATIONS

A brlef outline of geothermal regulatory agencles in the western United States, 30 a

Adainistrative laws of Callfornia"d state Land Comission; regulations pertaining to geothermal resources, 349

Environmental overview of geothermal resources development, 22

Federal regulations and lease terms and their regulationshlp to state laws and regulations, 303

Final environmental statement for the geothermal leasing program. Volume I, 365

Final environmental statement for the geothermal leasing program. Vol ume III, 367

Final environmental satement for the geothermal leasing progran. Volume IV, 368

Geothermal resources, present and future demand for power and legislation in the state of Uyoming.

Public intormation cerles 1, 67 (NP-21229)

Geothermal resources: leasing on public, acquired, and withdrawn lands, 321

Geothermal resources leasing and operations on public, acquired, and withdrawn lands. II, 423

Institutional and environmental problems in geotheraal resource development, 243 (NSF/RA/N-74-159)

Regulatory aspects of geothermal energy development in the Salton Sea/Inperial Valley Area, 186 (UCID-16807) Sumary gulde to the insti tutional problems confronting the geothermal energy industry, 244 (CONF-741145-1) GEOTHERMAL RESOURCES/RESEARCH PROGRAMS

Geothermal energy resource utilization progras planning, 66 (MTR-7137)

Geothermal resources research and technology, 245

Geothermal resources research (Needed basic and applited areas), 375

Geothereal resources research, 394

Imperial Valley's proposal to develop a guide for geothermal development ithin its county, 240 (NSF/RA/N-74-159)

The potential for energy production fros geothermal resources: Report of the Subconnittee on Water end Power Resources, Comittee on Interior and Insular 
Aefalre, United States senate. Ninety-Thlrd Congress, First session, 324

GEOTHERMAL RESOURCES/REVIEUS

Development of the Mation's geothermal energy resources, 170

Earth's heat tapped for geothe raal power development, 420 GEOTHERMAL RESOURCES/SOCIO-ECONONIC FACTORS

Development of geotherad energy in the Gulf coast: soclo-ceonoulc, demographic, and political considerations, 82 (CONF-760222-p5)

Some lscues regarding regulatory pollcy, political participation, and social iapilcations of geotheral resource development in the Imperial Valley, 74 (NP21381)

GEOTHERMAL RESOURCES/TAXES

Geothermal tax considerations and shel ters

(Implementation of IRS regulations 26 CFR. 613; 704; 731 ; 741 and 752 ), 229

Geothermal resources: legal and tax considerations, 291

Income taxation of geothermal resources, 20

Refch, Arthur E. and Carolyn $C$. Reteh vs Commlesion of Internal Revenue, U.3. Tax Court, July 31, 1969,456

state taxation of geothermal resources compared with otate taxation of other energy minerals, 133

GEOTHERMAL RESOURCES/TECHNOLOGY ASSESSMENT

A technology assessent of geothermal energy resource development, 184 (PB-246241)

GEOTHERMAL RESOURCES/USES

Multlpurpose geothermal resource development: an overvieH, 114

GEOTHERMAL RESOURCES/VOLCANOES

Hawa II volcano ene rgY, 336

GEOTHERMAL SPACE HEATING/BIBLIOGRAPHIES

Geothermal energy. Volume 2 . Search perlod covered: May 1975-April 1976. Citations from the NTIS Data Base, 137

GEOTHERMAL STEAM

SE NATURAL STEAM

GEOTHERMAL STEAM ACT

Geothermal Stean Act of 1970: known geothermal resources areas; partial list, 426

Classffication of public lands valuable for geothermal tean and associated geothermal resources, 434

Development of geothereal resources and the 1970 Geothermal stean Act: law in search of definition, 318 Disposition of geothermal stean, 471

Federal Geothermal Stean Act of 1970: Public Law 91-581, 344

Free electricity; plan to get more energy from heat Inside Earth moves forward bit (Geothermal Stean Act of 1970$), 442$

Geothermai leasing program, considers impact of leasing and operating regulations to implement the Geotherma Stean Act of 1970 and leasing of 3 areas in Callfornia. Draft envi ronmental Impact statement, 421 (PB-203102-D)

Geothermal steam act of 1965 (a bill to authorize the Secretary of the Interior to make disposition of geothermal steam and assoclated geothermal resources), $474(\mathrm{PD}-218830)$

Geothermal resources leasing: general, 320

Geothermal steam Act of 1970. Public Law 91-581,

Senate Res. 368, 91st Congress, Decenber 24, 1970, 391

Geothernal stean Act of 1970; procedure to be followed in claluing rights, 428

Geothermal tean act of 1970. Exploltation and development of geothermal steam resources, 448

Geothermal Steam Act of 1966 (S. 1674); nemorandun of disapproval, 14 Nov 1966, 466

Geothermal steam, 467

GEDTHERMAL STEAM ACT/COMPARATIVE EVALUATIONS

Geothermal steam Aet of 1970,440

GEOTHERMAL STEAM ACT/IMPLEMENTATION

Geothermal resources: leasing on public, acquired, and

il thdrawn lands, 321 geothermal atean act of 1970 , 429 (CONF-710571-)

GEOTHERHAL STEAK ACT/LEGAL ASPECTS

Geothermal Steas ACt of 1970,440

GEOTHERMAL SYSTEMS

SEe a 1 so GEDPRESSURED SYSTEMS

HOT-DRY-ROCK SYSTEMS

HOT-WATER SYSTEMS

HYDROTHERHAL SYSTEMS

GEOTHERMAL SYSTEMS / B IBLIOGRAPHIES

Geothermal energy. Vol ume 2. Search period covered Kay 1975-April 1976. Citations from the NTIS Data Base, 137

GEOTHERMAL SYSTEMS/EXPLOSIVE STIMULATION

Environmental aspects of nuclear stimulation, 380

GEOTHERMAL SYSTEMS/GEOLOGY

Technical overview of geothermal resources, 11

GEOTHERMAL SYSTEMS/LEGAL ASPECTS

Penultimate geothermal system in legal perspective, 269 (CONF-740209-)

GEOTHERMAL SYSTEMS/OFFSHORE SITES

Penultimate geothermal system in legal perspective, 269 (CONF-740209-)

GEOTHERMAL WELLS

Relch, A.E. et al. vs Commissloner of Internal Reverue and G.D. Rowan et al. vs Comal ssioner of Internal Revenue. U.S. Court of Appeals, Ninth Circuit. January 21, 1972 (Judicla) Interpretation of IRS tax regulations relative to depletion allowance for geotheral well drilling and development; 26 CFR 1. $263(\mathrm{c}), 1.611(\mathrm{a})$, and $1.613(\mathrm{~b})), \$ 16$

GEOTHERMAL WELLS/CLOSURES

Geothernal resources operational Order No. 3: plugging and abandonment of wells, 236

GEOTHERMAL UELLS/ENVIRONMENTAL IMPACTS

Environmental assessient of proposed geothermal well testing in the Tigre Lagoon oll fleid, Verallion Parlsh, Loulsiana, 68 (TID-27034)

Impacts of energy resources removal from Federal and Ind I an lands, 282

GEOTHERMAL WELLS/LEGAL ASPECTS

Majority opinion In the Relch case: question of depletion, 352

GEOTHERHAL WELLS/REGULATIONS

Geothermal well drilling and completion practices in Call fornia including casing and abandonment programs and examples of blowouts, 308

GEOTHERMAL WELLS/TAXES

Najorlty opjinion in the Reich case: question of depletion, 352

GEOTHERMAL WELLS/UELL COMPLETION

Geothernal resources operational order No. 2 : drilling. completion, and spacing of geothermal wells, 235

GEOTHERHAL WELLS/WELL DRILLING

Geothermal resources operational Order No. 2: drlliling, completion, and specing of geothermal wells, 235

Geothernal well drilling and completion practices in Callfornia Including casing and abandonment programs and examples of blowouts, 308

GEOTHERMAL WELLS/WELL SPACING

Geothermal resources operational Order No. 2: drilling completion, and spacing of geothermal wells, 235

GERMAN FEDERAL REPUBLIC/ENERGY POLICY

Reply fron the Federal Government concerning new primary energy sources, 55

GERMAN FEDERAL REPUBLIC/ENERGY SOURCES

Reply by the Federal Government to a question concerning new primary energy sources railed in the Bundestag. 57 GERMAN FEDERAL REPUBLIC/GEOTHERMAL ENERGY

Legal aspects of the utilization of geothermal heat, 75 GERMANY (FEDERAL REPUBLIC) SEe GERMAN FEDERAL REPUBLIC

GEYSERS GEOTHERMAL FIELD

Geothermal resources in Callfornis, 470

GEYSERS GEOTHERMAL FIELD/GEOTHERHAL POWER PLANTS

California public utilities conmission.: 146

Geothermal power expansi on in Callfornia, 266

Geothermal resources in California, 408

Geothermal resources in California-potentials and problens, 418

PGandE' geothernal power plant in california: the Geysers, 307

Union Oil testimony: Geysers Power Plant 12 hearing (Callfornia Public Utilities Conmission), 256

GEYSERS GEOTHERMAL FIELD/GEOTHERMAL UELLS

Majortity opinion in the Relch case: question of depletion, 352

GEYSERS GEOTHERMAL FIELD/HEARINGS

Hearing on the ownership of geothermal stean underlying Geysers. Geothermal Kinetics Inc., plaintlfe, vs Union Dil Company of Calfrornia, defendants, Fay 28, 1976, 33

GEYSERS GEOTHERMAL FIELD/NATURAL STEAM

Geothermal steam pricing at the Geysers, Lake and Sonon Counties, Callfornia, 100

GEYSERS GEDTHERMAL FIELD/OPERATION

Geothermal energy: legal problems of resource development, ios

GEYSERS GEOTHERMAL FIELD/POWER POTENTIAL

Geothermal activity in 1971, 400 (PB-218830)

GOVERNMENT POLICIES

See also ECONOMIC POLICY ENERGY POLICY

1977 guidebook to California taxes with special emphasis on relationship to Federal taxes, 25

A brief outline of geothermal regulatory agencles in the western United States, 304

Acquisition of geothermal rights: proposed methods. 478 An analysis of the ERDA plan and progran, 153 (PB-250636)

An analysis Identifyling issues in the flscal year 1976 ERDA budget. Report prepared for the Commltee on Sclence and Technology, U.S. House of Representatives, Comittee on Interlor and Insular Affalrs, U.S. Senate and the Joint Comittee on Atomlc Energy, NinetyFourth Congréss, First Session, 209

Appendix A: governance of geothermal energy development, 48 (JPL-5040-25(Rev.A)(APP.))

Appendix B: administrative requirements for development of geotheral resources, 49 (JPL-5040-25(Rev.A) (ApP.))

Authorlzing appropriatlons for the Energy Research and Development Administration. Conference report to ecompany H.R. 13350,106

Benefits of stimulating geothermal energy development with tax and research subsidies, 143

Boom towns may hinder energy resource development, 72

California Energy Workshop: developing plan of action to meet the energy crisis in Callfornia, 323 (PB237045 )

Comparative analysis of the 1976 ERDA plen and progran, 05

Constralnts on geothermal development: tax and beyond, 
Cooperative efforts by industry and government to develop geothermal resources, 241 (NSF/RA/N-74-159)

Decision statement of Secretary of Interlor on geotheraal resources program, 267

Departaent of the Interior fincl tatement, 353

Developant of the Nation's geotheral energy resources, 170

Development of geothermal resources and the 1970 Geotheraal Steam Act: lau in search of definition, 318

Economics of exhaustible resources. I. The pecullar problems of ineral weal th, 482

Electric power, fuel s development, and protection of the environient: legislation introduced in the 91 st Congress, 451

Electric utillties, 163 (JPL-5040-6(Vol.3))

Electric utility companies and geothermal power, 98

Energy: the new era (Book), 273

Energy and waterials, 384

Energy cholces and public policy, 158

Energy company: Donopoly trend in the energy markets, $430(\mathrm{~PB}-218830)$

Energy econonlcs, 56

Energy fuel aineral resources of the publlc lands. Volume I. Master report: a study prepared for the Public Land Law Review Conmision, 453

Energy legislation: Report of the Subcomittee on Energy of the Comittes on Sclence and Astronautics, U.S - House or Representatives, Ninety-Third Congress. Second Session, 277

Energy policles of the vorld: Venezuela, 221

Energy regulation by the Federal Power Commission, 326

Energy research policy alternatives. Hearing pursuant to S. Res. 45, a national luels and energy polley study, on exlsting federal energy research and development polleies and future technological options. U. S. Senate, June $7,1972,403$

Unergy taxes and subsidies, 314

Environmental laws and regulations, 166 (JPL-5040-6(Vol. 3)

Environentally sensitive land use regulation in Callfornia, 357

ERDA authorization, Fiscal Year 1977. Part III. Geotheral Hearing before the Subconmittes on Energy Research, Development and Demonstration of the Comittee on Sci ence and Teehnology, U.S. House of Representatives, Ninety-Fourth Congress, Second Representatives, Ninety-Fourth
Session, February $19,1976,132$

Ex-Assistant Administrator looks back on ERDA's 1st year. .and ahead to 2 nd, 60

EXOP report on federal energy $R$ and $D$ funding, 415 FEA: prices hold key to energy future, 63

Federal energy/environmental research and development progran, 212

Federal Energy Administration hearing on western regional resource development, 246

Federal organization for nonnuclear energy research and development activities of departments and agencies other than ERDA: FY 1976, 175 (NP-20699)

Federal role in geothermal resource development, 18

Federal tax policy and geothermal energy development, 331

Geothermal Energy Research, Development, and Demonstration Act of 1974, 167 (JPL-5040-6(Vol .3))

Geothermal resources, present and future demand for power and legislation in the State of Wyoming. Public information series 1,67 (NP-21229)

Geothermal Leasing Program, 396 (PB-208954)

Geothermal leasing program. (Supplement to draft dated 6 oct 1971, PB-203102-D), 397 (PB-208954)

Geothermal act Ivity in 1971,400 (PB-218830)

Geothermal stean ect of 1970 (exploitation and development of geothermal steam resources), 447 (PD218830 )

Geothermal energy in California: status report, 44 (JPL$5040-25($ Rev.A) (APP.))

Geothermal resource development process, 47 (JPL-504025(Rev.A)(APp.))

Geothermal energy, 94

Geothermal energy: legal problems of resource development, 105

Geothermal energy: prospects and limitations, 109

Geothermal development policy for an isolated state: the case of Hawali, 119

Geotheraal Environmental Advi sory Panel. Second annual report, July 1, 1975-June 30, 1976, 136

Geothermal energy. Volume 1. Search period covered: 1970-1974. Citations Erom the Engineering Index Data Base, 138

Geothermal power: strangled by red tape, 169

Geothermal energy development. Hearing before the Subcommittee on Energy Research and Water Resources of the Committee on Interior and Insular Affalrs, United States Senate, Ninety-Fourth Congress, First Session, 217

Geothermal Environmental Advisory Panel. First annual report, June 1, 1974-June 30, 1975, 225

Geothermal tax considerations and shelters, 229

Geothermal resources research and technology, 245

Geothermal power economics: an annotated bibliography. 278

Geothermal resources: legal and tax considerations, 291

Geothermal resources. Parts I and II. Hearings before the Subcomm ttee on Hater and Power Resources of the
Comittee on Interlor and Insular Arfairs, United States Senate, Minety-Third Congress, First Session, 297

Geothermal Energy Research, Development, and Comercial Demonstration Act of 1973; Geothermal Energy Researeh. Development, and Desonstrati on Ret of 1974. Hearings before the Subcomittee on Energy of the Conaltiee on Sclence and Astronauties, U.S. House of Representatives, Ninety-Third Congress, second session on H.R.11212 and H.R.14172, 300

Geothermal resources leasing: general, 320

Geothermal resources: leasing on public, acquired, and Wthdrawn lands, 321

Geotheraal energy. Hearlings before the Ninety-Second Congress, FI rat Session, U. S. House of

Representatives, Comittee on Science and Astronautics, Subconmi t tee on Energy, 371

Geotheraal stean Act of 1970. Public Law 91-581, Senate Res. 368, 91 st Congress, Decenber 24, 1970, 391

Geotheraal energy resources and research. Hearings pursuant to $S$. Res. 45, national fuels and energy policy study, on the role of geothermal energy resources in our Nation's future energy economy, June 15 and $22,1972,402$

Geotherael resources leasing and operations on public, acquired, and withdrawn lands. II, 423

Geothermal sclence and technology: a national prograe. 432

Geotheraal energy prospects in ralation to policy of regional utilization of energy resources in Indonesia, 435

Geotheraal steam Act of 1970,440

Geothermal resources in Callfornia, 470

Governmental leasing regulations, 290

Hewall geothermal project, 192

Hearing on the ownership of geotheraal steas underlying Geysers. Geotheraal KInetics Inc., plaintiff, vs Union 0il Company of Californla, defendants, Hay 28 , 1976,33

Highlights of energy related legislation in the 93rd Congress. Prepared at the request of Henry $M$. Jackson, Chalrman. Committee on Interior and Insular Affalrs, United States Senate pursuant to S.Res. 45, 215

Imperlal Valley environmental project, 59 (UCRL-52000-765)

Indians cautlous on development, 32

Institutional barriera to geothermal energy development. Second report of the Institutional Barrier Panel to the Geothermal Advisory Councl l, 134

Institutional, business, and financial aspects of the geothernal energy industry, 252

Internal Revenue Sorvice Regulat Ions, 458

Interstate environmental probleas: guide to water pollution and water scercity, 317

Lease of federal geothermal energy: rocky road (abstract), 34

Leasing and exploration, 162 (JPL-5040-6(Vol.3))

Legal, Institutional, and political probiems in producing electric power from geothermal resources in Callernia, 144

Legal and policy aspects of geothermal resource development, 398

Legal aspects of geothermal energy development, 126

Mineral leasing on Indian lands: report to the Federal Trade Commission, 151 (PB-246568)

Mining and minerals policy: 1976 bicentennial edition, $42(\mathrm{NP}-21355)$

Multi-purpose geothermal resource development: an overview, 91

Multipurpose geothermal resource development: an overview, 114

Observations on Federal Energy Research and Development, December 1974,71

One third of the nation's land: a report to the President and to the Congress by the Public Land Lav Review Commission, 452

Pacific Northwest geothermal: review and outlook, 61

Perspective for the 94th Congress, 311

Preliminary report on legal and public policy setting for geothermal resource development in Hawail, 279

President's message on energy, 1973, 373

Program definition for the development of geothermal energy. Volume II. Progran definition development rationale and subprogram descriptions, 160 (JPL-50406(Vol.2)

Program definition for the development of geothermal energy. Volume III. Appendixes, 161 (JPL-5040-6(Vol. ))

Proposed energy research and development program: Piscal year 1976/77. Callfornia Energy Resources Conservation and Development Commission, 73 (NP-21008)

Protecting the environment, 101

Publlc pollcy toward environment 1973: a review and appraisal. Nuclear and other energy, 358

Regulatory aspects of geothermal energy development in the Salton Sea/Imperial Valley Area, 186 (UCID-16807)

Reich, A.E. et al. vs Commissioner of Internal Revenue and G.D. Rowan et al. vs Commissioner of Internal Revenue. U.S. Court of Appeals, Ninth Circuit. January 21, 1972, 416

Report to the Congress: problems in identifying developlng, and using geothermal resources; 190 (NP20694) 
Results of an opinion survey on the 1977 budget proposal of the Energy Research and Development Administration. Printed at the requeat of Henry M. Jackson, Chalrman. Comaittee on Interfor and Insular Affalrs, United states Senate, 86

Revlew of Project Independence BIueprint panel abcomalttee reports on FEA-Interagency tesk forces. Report on CTAB recomendations for a national energy progran. Subcomittee working documents, 198 (COH-7510500)

Review of the Project Independence report subnitted to offlce of Energy Research end Development, Natlonal Selence Foundation, January 10, 1975, 195 (PB-238791)

Rules and regulat ions relating to geothermal leeses on Colorado state owned lands, 292

Selected portions of Callfornia state-wide geothermal regulations. Appendix $B, 305$

Some Issues regarding regulatory pollcy, political participation, and social implications of geothermal resource development in the Imperial valley, 74 (NP21381)

Some lssues regarding regulatory policy, polltical participation, and social implications of geotheral resource development in the Imperial valley, 142

Some reflections on the history of the United Nation and U.S. Government geothermal activities, 177

staff report to the Federal Trade Comission on federal energy land pollcy: effliciency, revenue, and competition, 152 ( $\mathrm{PB}-246663)$

state policies for geothermal development, 85 (NSF/RA$760230)$

state policy considerations for geothermal development in Hawat 1,185 (PB-243467/8ST)

state pollay considerations for geothernal development In Hawall, 171

State responses to the energy crials, 301

State taxation of geothermal resources compared with tate taxation of other energy ainerals, 133

structure of the geothermal industry through 1974, 238

studies in energy tax pollcy, 208

sumary gulde to the Institutional probleas conf ronting the geothermal energy industry, 244 (CONF-741145-1)

Sumary of ERDA patent pollcy relevant to geothermal energy, 165 (JPL-5040-6(Vol.3))

Sumary of Section XII: legal and Institutional aspects, 107

Summary report of the Cornell workshop on energy and the environnent. Hearling pursuant to $S$. Res. 45, a national fuels and energy policy study, U. S. Senate, February 22-24, 1972, 404

Tax treatment of exploring and developing geothermal resources, 334

The energy crisis and proposed solutlons. Panel discussions before the Comittee on Ways and Means, House of Representitives, NInety-Fourth Congress, First session on the energy crists and proposed olutions, part 3 of 4,201

The potentlal for energy production fron geothermal resources: Report of the Subcomittee on Water and Power Resources, Comil ttee on Interior and Insular Affairs, United States Senate, Ninety-Third Congress, First Session, 324

U.S. energy $R$ and D: polley and prlorlties, 294

U.S. taxes on energy resources, 183

United states or America Union ail Company or California. U.S. District Court, N.D. California Civ. No. $72-1866 \mathrm{GBH}, 389$

Water eupply: econoales, technology, and pollcy, 455 Why public policy must eupport geothermal developaent, 309

Uitnesses for oll: the case against dismemberment, 130 GOUERNAENT POLICIES/GEOTHERMAL ENERGY

Geothermal energy exploratlon, research, and developnent Report of the Comittee on Interlor and Insular Afrairs, United States Senate, Ninety-Third Congress, Second Session to eccompany S. 2465, 280

GOVERNHENT POLICIES/SOCIO-ECONOMIC FACTORS

Englneering manpower and energy needs. IV. Federal pollicles have an Iapact, 149

GREAT BRITAIN

SeE UNITED KINGDOA

H

HAUAII /ENERGY POLICY

Geothermal development pollcy for on loolated state: the case of Hawali, 119

Hawall geothermal profect, 192

HAUAII/ENERGY SOURCES

al ternate energy sources for Hawall Proceeding of the workshop held May 8-9, 1975, in Honolulu, Hawail, 219

HAUAII/GEOTHERMAL RESOURCES

Havali geotheraal profect, 192

Hawali vol cano energy, 336

state pollcy considerations for ceothermai development In Hawall, 185 (PB-243467/8ST)

state polley considerations for geothernal development In havall, 171

HAUATI/GOVERMHENT POLICIES

Preliainary report on legal and public polley setting for geotherel resource development in Hawall, 279
State polleles for geothermal development, 85 (NSF/RA760230 )

State policy considerations ror geothermal development in Hawali, 185 ( $\mathrm{PB}-243467 / 8 \mathrm{ST}$ )

HAWAII/LEGISLATION

Hawall geothermal law, 255

HEARINGS

America' energy potential: a sumary and explanation

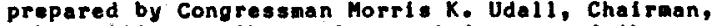
subcommittee on the envil ronment for use of the Comittee on Interior and Insular Aftalrs of the U.S. House of Representatives, Ninety-Third Congress, First Session, Oetober 1973,363

Compendium of papers presented at the Imperial Valley-Salton Sea a rea geotheraal hearing, Oet 22 and 23,450 Disposition of geothermal steam - 1967, 464

Dergy research pollcy alternatives. Hearing pursuant to 5 . Res. 45, a national quel s and energy polley study, on exlsting federal energy research and development pollcles and future technological options U. S. Senate, June $7,1972,403$

ERDA authorization, Fiscal Year 1977. Part IV. Basic energy sciences. Hearings before the Subcomittee on Energy Research, Development and Demonstration of the Committee on Science and Technology, U.S. House of Representetives, Ninaty-Fourth Congress, Second Session, February 26, 1976, 129

ERDA authorization. Fiseal Yaar 1977. Part III. Geothermal. Hearing before the subcomiltee on Energy Research, Development and Demonstration of the Conmit tee on Science and Technology, U.S. House of Representatives, Ninety-Fourth Congress, Second Sessi on, Fobruary 19, 1976, 132

ERDA authorization. Part II. 1976 and transition perlod: geothernal. Hearings before the Subconmit tee on Energy Research, Development, and Demonstration of the Comittee on Sclence and Technology, U.S. House of Representatives, NinetyFourth Congress, First Session, 203

Federal Energy Adinistration hearing on western reglonal resource development, 246

Final environmental statement for the geothermal leasing progran. Volume IV, 368

Geothermal Energy Research, Development, and Demonstration Act of 2974. Oversight hearings: loan guaranties. Hearings before the Subcomnittee on Energy Research, Development, and Demonstration of the Comittee on Science and Technology, U.S. House of Representatives, Ninety-fourth Congress, First session, 207

Geothermal energy development. Hearing before the Subcomittiee on Energy Research and Water Resources of the Comittee on Interior and Insular Affalrs, United states Senate, Ninety-Fourth Congress, First Session. 217

Geothermal energy: potentially the Nest's major energy resource, 247

Geothermal energy exploratlon, research and developent. Senate report No. 93-849,261

Geothermal resources. Hearings before the Subconalttee on Water and Power Resources of the Committee on Interlor and Inaular Affalrs, United States Senate, Ninety-Third Congrese, First session on the potential for the production of power from geothernal resources, 284 .

Geothermal resources. Parts I and II. Hearings before the Subcomittee on Water and Power Resources of the Comittee on Interior and Insular Arfalrs, United States Senate, Ninety-Third Congress; Firat Session, 297

Geothermal Energy Research, Development, and Comerclal Denonstration Act of 1973; Geotheraal Energy Research, Development, and Demonstration Act of 1974. Hearings before the Subcomalttee on Energy of the Committee on Selence and Astronautics, U.S. House of

Representetives, Ninety-Third Congress, Second Session on H.R.11212 and H.R.14172, 300

Geothermal energy. Hearings before the Ninety-Second Congress, First session, U. S. House of

Representatives, Committee on Science and Astronaut las. Subcomittee on Energy, 371

Geotheral energy. Hearlings before the subcomaltee on energy of the Committes on selence and Astronautice, United states House of Representatives, Ninety-Thlrd Congress, Firet Session on H.R. 6628, H.R. 9658 , September 11, 13, and $18,1973,379$

Geothermal resources (Potential for production of electrict ty and heat in Idaho), 382

Geothermal energy resources and research. Hearings pursuant to $S$. Res. 45, a national fuel and energy pollcy tudy, on the role of geothermal energy resources in our Nation's Puture energy econony, June 15 and $22,1972,402$

Geotheraal energy resources and research. Hearings before the Comnittee on Interlor and Insular Affairs, United States Senate, pursuant to $S$. Res. 45 , a national fuels and energy policy study, Ninety-second Congress, Second Session on the role of geothermal congress, Second Session on the role of geothermal energy resources in our nat

Geothermal ecience and technology: ational progran, 432 
Geothermal stean and resources, 446

Geothermal resources in Callfornia, 470

Hearing on the ownership of geothermal steam underlying Geysers. Geotherwal Kinetics Inc., plaintiff, vs Union Dil Company of Callfornia, defendents, May 28 , 1976,33

Nonnuclear energy research and development: fiscal year 1976 authorization. Hearings before the Subcomittee on Energy Research and Hater Resources of the Committee on Interior and Insular Affairs, United States Senate, Ninety-Four th Congress, First Session on $S .598,204$

Oversight hearings on Public Law 93-410: the Geothermal Energy Research, Development and Demonstration Act of 1974. Hearing before the Subcomattee on Energy Research, Development and Demonstration of the Committee on Sclence and Technology, U.S. House of Representatives, Ninety-Fourth Congress, Second Session, 103

Potential for energy production from geothermal resources. Report of the Subcomittee on Hater and Power Resources, Comittee on Interior and Insular Afrairs, Ninety-Third Congress, First Session, December 1973,378

Project Independence report, 287

Project Independence Blueprint: transeript of seventh public hearing, Houston, Texas, September 16-20, 1974, pas

Public hearing on geothernal energy and assoclated wineral resources, 475

Public interest vs. private portisanship in geothermal development, 178

Research, development, and the energy crisis. Hearlngs held Novenber $20,1973,383$

Senate Judiclary Comittee HB 2040: April 30, 1975, Oregon, 172

Statement at hearings before the committee on Interior and Insular Afralrs, 433

Sumary report of the Cornell workshop on energy and the environment. Hearling pursuant to s. Res. 45, netional fuels and energy policy study, U. S. Senate, February 22-24, 1972, 404

Union Oll testimony: Geysers Power Plant 12 hearing (California Public Utilities Conmission), 256

HEBER GEOTHERHAL FIELD/LAND USE

Effects of geothermal development on the agricultural resources of the Imperial Valley, 6

HOT SPRINGS/FLUID UITHDRAWAL

Possible conflict between the interests of tourism and geothermal power development, 127

HOT SPRINGS/SOCIO-ECONOMIC FACTORS

Possible conflict between the interests of tourism and geothergal power development, 127

HOT-DRY-ROCK SYSTEMS

Geothermal energy resources (Group position paper, 3 subgroup papers, and 1 revien paper), 156 (CONF-750720)$_{-1}$

SYRTEMS

Geothermal energy resources (Group position paper, 3 subgroup papers, and 1 review paper), 156 (CONF-750720)

HUMAN POPULATIONS/MIGRATION

Population analysis relative to geothermal energy

development, Imperial County, Califomia, 8

HYDROELECTRIC PÓWER

Al ternative sources of energy: practical technology and phllosophy for a decentralized soclety, 213

HYDROELECTRIC POWER/ENUIRONMENTAL EFFECTS

Protecting the environient, 101

HYDROELECTRIC POWER PLANTS

Natural resources development and policles, Including envi roneental considerations, 437

HYDROELECTRIC POWER PLANTS NATER REQUIREMENTS

Uestern atates water requirements for energy development to 1990,249 (NP-20555)

HYDROELECTRICITY

SE HYDROELECTRIC POWER

HYDROTHERMAL SYSTEKS

SEe aI so GEOTHERMAL SYSTEMS HOT-HATER SYSTEMS

HYDROTHERMAL SYSTEMS/POUER POTENTIAL

Potential national benefits of geothernal electrical energy production from hydrothermal resources in the West, 97

\section{I}

\section{ICELAND/LEGISLATION}

Lay of Iceland as it affects geothermal development, 123 ICELAND/RECREATI ONAL AREAS

Possible conflict between the interests of tourisn and geothermal power development, 127

IDAHO/ENERGY SOURCES

Financing Infrastructure in energy developwent areas in the Hest. Proceeding of a conference held August 2 and 22, 1975, In Snowbird, Utah, 218

IDAHO/GEOTHERMAL RESOURCES

Geothermal energy development. Hearing before the Subcomittee on Energy Research and Water Resources of the Comittee on Interior and Insular Afralrs, United
217

Geothernal resources, 382

Paclfic Northwest geothermal: review and outlook, 61

IDAHO/GOVERNMENT POLICIES

State pollcies for geothermal development, 85 (NSF/RA760230 )

IDAHO/LEG I LLATION

Idaho Legislature, 354

IDAHO/US ORGANIZATIONS

A brief outline of geothermal regulatory agencies in the western United States, 304

IDAHO/WATER RESOURCES

Western states water requirements for energy development to 1990,249 (NP-20555)

IMPERI AL VALLEY

See a 1 so EAST MESA GEOTHERMAL FIELD

Regulatory aspects of geothermal energy development in the Salton Sea/Imperial Valley Area, 186 (UCID-16807)

IMPERIAL VALLEY/AGRI CULTURE

Effects of geothermal development on the agricultural resources of the Imperial Valley, 6

IMPERIAL VALLEY/ECONOMY

Costs of geothermal energy development. Final report, January 1977,3

Economic lapact of geothermal energy development, 5

Multisector analysis of the impact of geothermal development on the economy of Imperfal County, California, 28

IHPERIAL VALLEY/ENERGY SOURCE DEVELOPMENT

Economic Impact of geothermal energy development, 5 Goographical environmental analysis. Final report, 29

Imperial Valley"s proposal to develop gulde for geothermal development within its county, 240 (NSF/RA/N-74-159)

Regulatory, planning and policy aspects of geotheraal energy development in Imperial County, California,

IMPERIAL VALLEY/ENVI RONMENTAL IMPACTS

Imperial Valley environnental project, 59 (UCRL-52000-765

ImPERIAL VALLEY/GeOThermal POHER PLANTS

Interrelationship between lederal, state, and local regulatory agencies on the development of the geothermai resource in Callfornia, 342

IMPERIAL VALLEY/GEOTHERMAL RESOURCES

Compendium of papers presented at the Imperial Valley-salton sea area geothermal hearing, 0ct 22 and 23,450 Geothermal activity in 1971, 400 ( $\mathrm{PB}-218830$ )

Imperial Valley's proposal to develop a gulde for geothermal developaent within its county, 240 (NSF/RA/N-74-159)

Interdisciplinary planning for geothermal development at the county level, 99

Opinion about geothermal development in Imperial county California, 1976. Final report, 7

Some issues regarding regulatory policy, polftical participation, and social implications of geothermal resource development in the Imperial Valley, 74 (NP21381)

Terms, conditions, standards, and application procedures for Initial geothermal development: Imperial County, Callfornia, 351

IMPERIAL VALLEY/LAND USE

Effects of geothermal development on the agricultural resources of the Imperial Valley, 6

IMPERIAL VALLEY/POPULATION DYHAMICS

Population analysis relative to geotheral energy development, Imperial County, California, 8

IMPERIAL VALLEY/PUBLIC OPINION

Opinion about geothermal development in Imperial county California, 1976. Final report, 7

some issues regarding regulatory policy, political particlpation, and social Implications of geotheral resource development in the Imperlal Valley, 142

IMPERMEABLE DRY ROCK SEE HOT-DRY-ROCK SYSTEMS

INDIAN LANDS

Institutional barriers.to geothermal energy development Second report of the Institutional Barrier Panel to the Geotheral Advi sory Council, 134

INDI AN LANDS/ENERGY SOURCE DEVELOPRENT

Iapacts of energy resources removal from federal and Ind 1 an 1 ands, 282

Indlans cautious on development, 32

INDIAN LANDS/LEASING

Mineral leasing on Indlan lands: report to the Federal Trade Commision, 151 (PB-246568)

INDONESIA/GEOTHERMAL RESOURCES

Geothermal energy prospects in relation to pollcy of reglonal utilization of energy resources in Indonesla, 435

INDUSTRIAL PLANTS/FINANCING

Financing Infrastructure in energy development areas In the West. Proceedings or a conference held August 21 and 22,1975 , in snowbird, Utah, 218

INDUSTRY

SEe al so CDAL INDUSTRY

NATURAL GAS INDUSTRY

PETROLEUM INDUSTR

INDUSTRY/ENERGY SOURCE DEVELOPMENT

Cooperative efforts by Industry and government to devel op geothermal resources, 241 (NSF/RA/N-74-159)

INDUSTRY/RESEARCH PROGRAMS

Cooperative efforts by Industry and government to 
develop geotheraal resources, 241 (NSF/RA/N-74-169) IXSTITUTIONAL BARRIERS

Inst I tut Ional and environaental aspects of geothermal energy development, 1

Sumary guide to the institutional problens confronting

the geotheral energy industry, 283

United states 1 aw as it affects geotherial development,

IMTERNAL REVENUE SERVICE/REGULATIONS

Internal Revenue Service Regulatlons (Mineral depletion al lowances for tax purposes), 468

IOWA/ENERGY CONSUMPTION

Energy: 1975. The tirst ennual report of the Iowe Energy Polley Councll, 194 (NP-20667)

IOUA/ENERGY POLICY

Energy: 1975. The first annual report of the Iowa Energy Polley Council, 194 (NP-20667)

IOUA/ENERGY SOURCES

Energy: 1975. The liret annual report of the Iowe

Energy Policy Council, 194 (NP-20667)

JAPAN/GEOTHERHAL ENERGY

Government activity report on geothermal energy in Japan, 112

JAPAN/LEGISLATION

Geothermal rights and problems of leglel ation in Japan, 122

JAPAN/RESEARCH PROGRAMS

Government activity report on geothermal energy in Japan, 112

JOINT VENTURES

Geothermal resources joint ventures, 13

$\mathbf{k}$

KGRA

(Known geotheral resource area.)

Geothermal Steam Act of 1970: known geothermal

resources areas; partial 11st, 426

$\mathbf{L}$

\section{LAND LEASING}

Adninistrative requilrements for developaent of geothermal resources, 15 ?

Adminlstrative laws of Calltornia's state Land Comission: regulations pertaining to geothermal resources, 349

Afternoon General Session, Friday, 11 May 1973, 341

Appendix B: administrative requirements for development of geothermal resources, 49 (JPL-5040-25(Rev.A)(APP.)

California's geothermal lands: a legal eramework for resource development, 121

Callfornla laws for the conservation of geothermal energy, an act to anend the heading of Chapter 4, and to add to Chapter 3, Division 3 , of the Public to add to Chapter 3 , Division 3 , of the Public

Contents of geothermal lease: some suggestions, 87

Dinner Session, thursday, 10 May 1973, 339

Energy fuel mineral resources of the public lands. Volume VI: Legal study of coal resources on public lands; geothermal resources on public lands. Interim report, 443 (PB-196325)

Envitronmental Impacts of geothermal resource development on conmercial agriculture: a case study of land use conflict, 131

Environmental planning for the geothermal leasing program on public lands, 285

Envi ronmental impact tatement for the Geothermal Leasing Prograi, 392

Exploration and development of geothermal resources in the United States, 1968 to 1975,113

Federal Geothermal Stean Act of 1970: Public Law 91-581, 344

Final environmental atatement for the geothermal leasing program. Volume I. Promulgation of leasing and operating regulations, $360(N P-20212)$

Final environmental satement for the geothermal leasing program. Volume I, 365

Final environmental tatement for the geothermol leasing progran. Volune II, 366

Final environmental statement for the geothermal leasing progras. Volume III, 367

Final environmental statement for the geothermal leasing program. Volume IV, 368

Flow chart of critlcai path in geothermal exploration, 343

Geothermal Leasing Program. Volume II. Leasing of geothermal resources in three Callfornia areas. Final envi ronmental inpact tatement (Clear Lake, Mono Lake, Imperial Val ley), 327 (EIS-CA-73-1681-F-2)

Geothermal Leasing Prograw. Volume IV. Appendix I. Comments on draft impact statement and proposed regulations. Final environmental Impact statement, 329 (EIS-CA-73-1681-F-4)

Geothermal resources, present and future demand for pover and leglelation in the state of Hyoming.

Public inforation eries 1, 67 (NP-21229)

Geothermal Leasing Progran, 396 (PB-208954)

Geothermal leasing practlees, 12

Geothermal resource development process, 47 (JPL-504025(Rev.A)(App.))

Geothermal energy: an industry appraisal, 69

Geothermal exploration: trategy and budgeting, 181

Geothermal energy: the challenges that lle ahead (Part 2 of two-pert article), 193

Geothernal anergy and the law. management program, 224

Geothermal resource characterist les, exploration considerations, and property acquisition techniques, 251

Geothermal resources legal and tax considerations, 263 Geothermal power expansion in Californta, 266

Geothermal exploration on public lands: when and under what conditions, 337

Geothermal energy resources and research. Hearings before the Comittee on Interior and Insular nffalrs United statea senate, pursuant to $S$. Res. 45, a national fuels and energy policy study, Ninety-second Congress, Second session on the role of geothermal energy resources in our nation's future energy econony, June 15 and $22,1972,407$

Geotheraal exploration and development in Nevada, 409

Geotheraal resources leasing and operatlons on public, acquired, and withdrawn lands . II, 423

Geothermal tean act of 1970. Exploitation and development of geothermal steam resources, 448

Implementing the federal geothermal tean act of 1970 , 429 (CONF-710571-)

Institutional, business, and financial aspects of the geotheral energy Industry, 252

Interrelatlonshlp between federal, tate, and local regulatory agencles on the development of the geotheraal resource in California, 342

Interrelationship between Federal, state and Local Regulatory Agencies, 355

Law of oll and gas, 441

Leasing and exploration (For geothermal resource assessment and development), 162 (JPL-5040-6(Vol.3))

leasing of Federal geothermal resources, 242 (NSF/RA/N$74-159$ )

Leasing on public, acquitred and withdrawn lands; revision of proposed rule, 347

Legal, institutional, and environmental, 79 (CONF-760222p1)

Legal, Institutional, and political problems in producing electric power Iron geothermal resources in Callfornia, 144

Legal aspects of geothermal energy development, 126

Luncheon Session, Thursday, 10 May 1973, 340

Maximum and timeiy commercial development of donestic geothermal energy, 179

Overview of the California permitting process, 23

President' message on upply of energy and clean alr, also fact sheet from orfice of the White House Press Secretary, 425

Property systens in geothermal resources: a critique and recommendations, 118

Public opinion concerning geothermal development in lake county, California, 65 (LBL-4447)

Public opinton in Cobb Valley concerning geothermal development in Lake County, Callfornia, 50 (LBL-5204)

Recent developments in the taxation of geothermal exploration, 485

Recent geothermal developments in Colorado, 174

Regulatory aspects of geothermal energy development in the Salton Sea/Imperial Valley Area, 186 (UCID-16807)

Report to the Congress: problems in identifying. developing, and using geothernal resources, 190 (NP20694)

Report to the Congress. Problems in identifying, developing, end using geothermal resources, 189 (TID26866)

Role of municlpalities in geothermal resource development, 14

Role of public lands in geothermal energy, 199 (CONF750612-)

Role of the state Lands Division in developing geothermal resources in Callfornta, 70

state pollcies for geothermal development, 65 (NSF/RA760230 )

Structure of the geothermal Industry through 1974, 238

Summer Lake Basin geothermal leasing: Environmental Ana Iys Is Record, 51 (NP-21256)

United states law as it afrects geothermal development, 115

United States of America vs Union 011 Company of Calleornia. U.S. District Court, N.D. California Civ. No. $72-1866 \mathrm{GBH}, 389$

Unitization for geothermal resources: unfted we save, 17 LAND LEASING/ENVIRONMENTAL EFFECTS

United States geothermal legislation and environmental impact for leasing. 390

LAND LEASING/ENUIRONMENTAL IMPACT STATEMENTS

Comments on draft environmental lupact stetement for the federal geothermal leasing prograns, 436

Environmental Impact statement for the geothermal

leasing program; draft 422 
Geothermal leasing program. (Supplement to draft dated 6 Det 1971, PB-203102-D), 397 (PB-208954)

Geothermal leasing program (draft environaental inpect statement), 431 (PD-218830)

LAND LEASING/GOVERNMENT POLICIES

Geotheraal leasing prograw. (Supplement to draft dated 6 Det 1971, PB-203102-D), 397 (PB-208954)

Geothermal steam act of 1970 (exploltation and development of geothermal etean resources), 447 (PD218830)

Governmental leasling regulations, 290

Lease of federal geothermal energy: rocky road (abatract), 34

Mineral leasing on Indian lands: report to the Federal Trade Comission, 151 (PB-246568)

Staff report to the Federal Trade Conalsalon on federal energy land pollcy: erficiency, revenue, and competition, $152(\mathrm{~PB}-246663)$

US poliey on land leasing for geothermal energy development, 353

LAND LEASING/LEGAL ASPECTS

Analysis of the usual oll and ges lease provistons, 479 State, federal lawakers weigh geothermal leasing, 459

LAND LEASING/LEGISLATION

Geothermal steam act of 1965 (a blll to authorize the Secretary of the Interior to aake disposition of geothermal steam and assoclated geothermal resources), $474(\mathrm{PD}-218830)$

Geothermal stean leasing; hearings before subconalttee on Minerals, Materlals and Fuels on $s .23$ and $S .912$, March 12-22, 1970,465

Proposed rule aking: geothernal resources - leasing on public, acquired and withdrawn lands; revision of proposed rule, 345

United States geothermal legislation and environmental iapact for leasing, 390

US pollcy on land leasing for geothermal energy development, 353

LAND LEASING/REGULATIDNS

Federal government leasing and operating regulations and envi ronmental impact statements, 414

Federal regulations and lease teris and their regulationship to state laws and regulations, 303 Geothermal resource characterletles, exploration considerations, and property acquisition techniques, 270 (CONF-741145-3)

Geothermal Leasing Program. Volune I. Pronulgation of leasing and operating regulations. Final

envi ronmental Impact tatement, 326 (EIS-CA-73-1681-F1)

Geothermal Leasing Program. Volume III. Appendices A through H. Proposed geothermal, leasing, and operating regulations. Final environmental iapact statement, 328 (EIS-CA-73-2681-F-3)

Geothermal i easing prograw, considers impect of leasing and operating regulations to Implement the Geothermal stea Act of 1970 and leasing of 3 areas in Callfornia. Draft envi ronmental impact statement, 421 (PB-203102-D) Geothermal resources leasing: general, 320

Geothermal resources leasing: general

Rules and regulations relating to geothermal leases on Colorado state owned lands, 292

LAND POLLUTION ABATEMENT

Geothermal Environmental Advisory Panel. Second annual report July $1,1975-J u n e 30,1076,136$

Geotheraal Environmental Advisory Panel. First annual report, June 1, 1974-June 30, 1975, 225

Geothermal resources operational Order No. 2: drilling, completion, and spacing of geothermal wells, 235

Geothermal Steam Act of 1970. Public Law 91-581, Senate Res. 368, 91st Congress, December 24, 1970, 391

LAND RECLAMATION

Geothermal resources operational (GRO) Order No. for central and western regions, 168

Geotherwal resources operati onal Order No. 1 exploratory operations, 234

Geothermal resources - operetions on public, acquired and withdrawn lands; notlce of proposed rulemaking, 346

Geothermal energy lands outlined, 461

Impacts of energy resources removal from Federal and Indian lands, 282

LAND RECLAMATION/LEGAL ASPECTS

Geothermal resources operational Order No. 4: general environmental protection requirements, 237

LAND USE

Benefits and costs to landowners from geothermal resource lease and development, 140

Development of geotheral resources and the 1970 Geothermal stean Act: law in search of definition, 318

Economic and social aspects of geothermal energy resource development, 128

Effects of geothermal development on the agricultural resources of the Imperial Valley, 6

EIR's: truth and consequences, 306

Energy In Texas. Volume II. Pollcy alternatives, 281

Energy legislation. Report of the Subcommittee on Energy of the Comnittee on Sclence and Astronautics, U.S - House of Representatives, Ninety-ThIrd Congress, Second Session, 277

Engineering manpower and energy needs. IV. Foderal pollcles have an inpact, 149

Environmental laws and regulations, 166 (JPL-5040-6( Vol.
3))

Environnental assessaent of proposed geothermal well testing in the Tigre Lagoon oli Fleid, Vermilion Parlsh, Louldana, 68 (TID-27034)

Envifondental overvieu of geotheraal resources development, 22

Envi ronmental impacts of geothermal resource development on commercial agriculture: a case study or land use conflict, 131

Federal Geothermal stean Act of 1970: Public Lau 91-581. 344

Federal role In geothermal resource development, 18

Geographical environmental analysis. Final report, 29 Geothermal resource characteristles, exploration considerations, and property acquisition techniques, 270 (CONF-741145-3)

Geotheral resources of the Texas Gulf Coast: environmental concerns arising from the production and disposal of geothermal waters, 83 (CONF-760222-P5)

Geothermal leasing practices, 12

Geotheral resources: water and other conflicts encountered by the developer. An alternative energy source which is "ogthering stean'" I5

Geothermal rights and problens of legisiation in Japan, 122

Geothermal resources operational (GRO) Order No. 4 ror central and western regions, 168

Geothermal energy: an Industry appralsal, 232 Geothermal resources operational Order No. 1 exploratory operations, 234

Geothermal resources operational Order No. 4: general envi ronmental protection requirements, 237

Geotheral resource characteristics, exploration considerations, and property acquisition techniques. 251

Geothermal resources - operations on publlc, acquired and withdrawn lands; notice of proposed rulemaking, 346 Geotheral resources, 382

Impacts of energy resources removal from Federal and Indian lands, 282

Imperial Valley' proposal to develop a gulde for geothermal development within its county, 240 (NSF/RA/N-74-159)

Indians cautlous on development, 32

Institutional and environaental aspects of geotheraal energy development, 1

Possible conflict betueen the Interests of tourlsa and geothermal power development, 127

Proceedings of the workshop on environmental aspects of geothermal resources development, 20-22 September 1974, 315

Property eystens in geothermal resources: a critique and recomendations, 118

Proposed rule making: jeothermal resources - leasing on public, acquired and withdrawn lands; revision of proposed rule, 345

Some issues regarding regulatory policy, political particlpation, and social iaplications of geothermal resource development in the Imperial Valley, 74 (NP21381)

Some issues regarding regulatory pollcy, political particlpation, and oocial implicat lons of geothermal resource development in the Imperial Valley, 142

Sumer Lake Basin geothermal leasing: Environmental Analysis Record, 51 (NP-21256)

Susanville project requi rements, 37 (SAN-1077-4)

Terms, conditions, standards, and applicatlon procedures for initial geothermal development: Imperial County. California, 351

Toward a theory of property rights, 460

LAND USE/GOUERNAENT POLICIES

Institutional barriers to geothermal energy development. Second report of the Institutional Barrier Panel to the Geothermal Advisory Councll, 134

LAND USE/LEGAL ASPECTS

Energy development and 1 and use in Texas: Final report on Project E/S-1: Impact on land use and value of alternative trategles for production, distribution and utilization of energy in Texas in the perlod 19742000,211

Environmentally sensitive land use regulation in California, 357

LAND USE/MANAGEMENT

One third of the nation's land: a report to the President and to the Congress by the Public Land Law Review Commision, 452

LAND USE/REVIEUS

One third of the nation's land: report to the President and to the con

Review Commisston, 45

LANDOWNER/MINERAL RIGHTS

Property theories affecting the landowner In a new ofl and gas producing state, 480

LANDOWNER / OWNERSHI P RIGHTS

Property theories affecting the landowner in a new of LAWS gas producing state, 480

\section{SEe also MINING LAWS}

NAT IONAL. ENVIRONMENTAL POLICY ACT

Acquisition of geothermal rights: proposed methods, 478

Administrative laws of Calffornias state Land Commission; regulations pertaining to geothermal resources, 349

Benefits and costs to landowners from geothermal 
resource lease and development, 140

California public resources code: statutes pertaining to geotheraal resources, 348

Callfornla laws for the conservation of geothermal energy, an act to amend the heading of Chapter 4, and to add to Chapter 3, Division 3, of the Publite Resources Code, relating to geotherwal resources, 463 Californit law for the conservation of geothermal energy (Chapter 1483, Statutes of 1965), an act to add Chapter 4, Division 3 , to the Public Resources Code, relating to geothermal energy and assoclated resources. 476

Constraints on geothermal development: tax and beyond, 19

Declsion statement of Secretary of Interlor on geothermal rasources progras, 267

Development of geothermal laws and regulations, 302

Development of geothermal resources and the 1970

Geothermal stean Act: law in search of definition, 318

Envi ronental laws and regulations, 166 (JPL-5040-6(Vol. 3))

Envi ronmentally sensitive land use regulation In

Callfornia. 357

Evolution of oll and gas law, 481

Federal regulations and lease terms and thelr regulationship to state laws and regulatione, 303

Geothermal resources: vater and other conflicts encountered by the developer. An alternative energy source which is "gathering tean". 15

Geothermal ales contracts, 21

Geothermal energy research, development, dewonstration, and production; Federal guarantes on loans, 58

Geotheral energy and the law. I. The federal lands management program, 224

Geothermal Energy Research, Development, and Demonstration Act of 1974 . Subuitted by Mr. Teague, Committee on Science and Astronautics, to the House of Representatives, Ninety-ThIrd Congress, Second Session, 274

Geothermal resources: legal and tax considerations, 291 Geothermal steam Act of 1970. Public Lay 91-581, Senate Res. 368, 91st Congress, Decenber 24, 1970, 391 Geothermal Stean Act of 1970,440

Impact of tat and federal iaw on development of geothereal resources in Texas. Project $L / R-9$, final report, 254 (NSF-RA-N-74-244)

Impact of state and federal law on development of geotheraal resources in Texas, 299

Incone taxation of geothermal resources, 20

Initlal exploratory well covenant. III, 477

Interstate environmental problems: aulde to water poliution and water scarcity, 317

Law and geothermal development in New Zealand, 126

Law needed $f$ or geothermal energy, 268

Law of Icelind as it affects geothermal development, 123

Law of oll and gas, 441

Laws, regulations, and soclal constraints to the development of geothermal energy, 139

legal, Institutional, and environmental, 79 (CONF-760222P2)

Legal aspects of geothermal energy development, 126

Legal issues In the development of geopressured geotheraal resources of Texas and Loulsiana Gulf Coast (Summary), 31

(Sumary), Si, or electric compenies in 1974, 264

Legieletive goalo or electric companies in 1974 , President and to the Congress by the Public land Law Review Commission, 452

Overview of the California permitting process, 23

Property systems in geothermal resources: critique and recomendations, 118

Property theories affecting the landowner in now ofl and gas producing state, 480

Review of some of the legal problems In geothermal development, 413

Role of munlcipallties in geothermal resource development, 14

Role of the state Land Divialon in developing geothermal resources in Callfornia, 70

Structure of the geotheral industry through 1974, 238

summary and concluding remarks, 24

Tax treatment of exploring and developing geothermal resources, 334

United states law as it afects geothermal development, 115

Unfted States of America va Union dil Company of Callernia U.S. Distriet Court, N.D. California Civ. No. 72-1866 $68 \mathrm{~B}, 389$

Unitization for geothersal resources: united we save, 17

Water supply: economles, technology, and pollcy, 455 LEASES

Benef It and costs to landowners from geothermal resource lease and development, 140

Contents of a geotheral lease: some suggestions, 87

Energy in Oklahoma. Volume one. Final report of

Okl hohoma Energy Advi wory Council, February 1, 1974, 276

Energy eeilt-sufficlency: how much; how soon, 216

Geotheraal resources operational Order No.? production and royei ty measurement, equipment, and testing procedures, 27

Geothermal energy and the 1aw. . I. The rederal lands manageaent program, 224

Geotherasl resources operational Order No. 3: plugging and abandonment of vells, 236
Geotheraal: wo wee it today, 253

Geothermal resources leasing: general, 320

Geothermal resources: leasing on public, acquired, and whdrawn lands, 321

Geothermal resources leasing and operations on public, acquired, and withdrawn lands. II, 423

Geothermal stean Act of 1970,440

Governmental leasing regulations, 290

mpacts of energy resources removal from federal and Indl an lands, 282

Institutional barriers to geothermal energy development. Second report of the Institutional Barrier Panel to the Geothermal Advisory Council, 134

Institutional barriers to geothermal energy development. A report by the Institutional Barrier Panel to the Geothermal Adv \$sory Councll, 135

Internal Revenue Service Regulations, 458

Law of oll and gas, 441

One third of the nation's land: a report to the President and to the Congress by the Public Land Lav Revieu Comission, 452

President' mesage on energy, 1973, 373

Property theorles affecting the landowner In a new oll and gas producing tate, 480

structure of the geotheraal Industry through 1974,238

Sumary guide to the institutional problems confronting the geothermal energy Industry, 244 (CONF-741145-1)

Victory sand and Concrete. Ince us Comissloner of Internal Revenue, January 2, 1974, 319

LEASES/DOCUMENT TYPES

Analysis of the usual ofl and gas lease provisions, 479 Initial exploratory well covenant. III, 477

LEASES/LEGAL ASPECTS

Initial exploratory well covenant. III, 477

LEASING

Acquisition of geotheral rights: proposed wethods, 478 Evolution of of 1 and gas law, 481

Geothermal leasing practices, 12

Geothermal eneroy: legal problems of resource development, 105

Geothermal power: strangled by red tape, 169

Geothermal energy development. Hearing before the Subcomnittee on Energy Research and Water Resources of the Comnittee on Interlor and Insular Affalrs, United States Senate, Ninety-fourth Congress, First Session, 217

Hearing on the ownership of geothermal tean underlying Geysers. Geotheral Kinetlcs Inc., plaintilf, vs Union 011 Company of California, defendants, May 28 , 1976, 33

Indians cautlous on development, 32

Institutional barriers to geothermal energy developaent second report of the Institutional Barrier Panel to the Geothermal Advisory Council, 134

Inst Itut I onal barriers to geothermel energy developent. A report by the Institutional Barrier Panel to the Geothermal Advisory Council, 135

Legal, Institutional, and political problems in producing electric power from geothermal resources in Callfornia, 144

Mineral leasing on Indian lands: report to the Federal Trode Commlasion, 151 ( $P B-246568$ )

Mining and ineral polfcy: 1976 bicentennial edition. $42(N \mathrm{P}-21355)$

Hestern otates water requirements for energy development to 1990,249 (NP-20555)

LEGAL ASPECTS

Geothermal energy and its uses: technical, economic, onvironmental, and legal aspects, 110

LEGAL BARRIERS

United states law as it iffects geothermal development, 116

LEGAL DEFINITIONS

Geothermal: the problem of definition, 338

LEGISLATION

Geothermal stean Act of 1970: known geothermal

resources areas; partial liat, 426

A technology asesesent of geothermal energy resource development, 184 (PB-246241)

Acquisition of geothermal rights: proposed aethods, 478

Administrative laws of California's state Land Coamision: regulation perteining to geotheral resources, 349

Adintetrative law of Callfornia's resources agency: portion of the directions for preparing environmental Inpact reports, 350

Authorizing approprlatlons for the Energy Research and Development Administration. Conference report to ccompany H. R. 13350,106

Authorizing the Secretary of the Interior to make disposition of geothermal tean and associated geothermal resources report to accompany S. 368,444

Boom towns way hinder energy resource developaent, 72

Callfornla's geothermal lands: a legal frasework for resource development, 121

Californla geothermal resources: how well are ve doing, 124

Callfornia public resources code: etatutes pertaining to geothermal resources, 348

California's geotherinal resources, 462

Cellfornia laws for the conservation of geotheral eneirgy (Chapter 1483, statutes of 1965), an ect to add 
Chapter 4, Division 3, to the Public Resources Code, relating to geothermal energy and assocleted resources, 476

Classification of public lands valuable for geothermal steam and assoclated geothermal resources, 434

Critical national choice: new energy horizons...or horizontal disintegration, 104

Department of the Interlor final statement, 353

Development of the Nation's geothermal energy resources. II, 154

Dinner Session, Thursday, 10 May 1973, 339

Disposition of geothermal steam - 1967, 464

Disposition of geothermal stean, 471

EIR's: truth and consequences, 306

Electric power, fuels development, and protection of the environment: legislation introduced in the $91 \mathrm{st}$ Congress, 451

Energy cholces and public pollcy, $1 \approx 8$

Energy development and $l$ and use in Texas. Final report on Project E/S-1: impact on land use and value or alternative strategies for production, distribution, and utilization of energy in Texas in the perlod 19742000,211

Energy legislation. Report of the Subcommittee on Energy of the Comittee on Science and Astronautics, U.S - House or Representat Ives, Ninety-ThI rd Congresa, Second session, 277

ERDA authorization, Fiscal Year 1977. Part IV. Basic energy sciences. Hearings before the Subcommittee on Energy Research, Development and Demonstration of the Comittee on Science and Technology, U.S. House of Representatives, Ninety-fourth Congress, Second Representatives, Ninety-Four th
Session, February 26, 1976, 129

ERDA authorization, Fiscal Year 1977. Part III. Geothermal. Hearing before the Subcomittee on Energy Research, Development and Demonstration of the Comittee on Science and Technology, U.S. House of Representatives, Ninety-Fourth Congress, Second Session, February 19, 1976, 132

Ex-Assistant Administrator looks back on ERDA's 1st year.. -and ahead to 2nd, 60

federal energy/environmental research and development program, 212

Federal Geothermal steam Act of 1970: Public Law 91-581, 344

Federal government 1 easing and operating regulations and envi ronmental impact statements, 414

Free electricity; plan to get more energy from heat inside Earth moves forward a bit (Geothermal stean Act of 1970$), 442$

Geothermai Energy Research, Development, and

Demonstration Act of 1974, 167 (JPL-5040-6(Vol.3))

Geothermal energy: economic potential of three sites in

Al aska, 200

Geothermal resources, present and future demand for power and legislation in the State of Wyowing.

power and legislation in the state of Wyowing

Geothermal leasing prograa (draft environmental impact statement), 431 (PD-218830)

Geothermal steam act of 1970 (exploitation and development of geothermal stean resources), 447 (PD218830)

Geothermal steam act of 1965 (a bill to authorize the Secretary of the Interlor to make disposition of geotheraal atean and assoclated geothermal resources), 474 (PD-218830)

Geothermal resources: water and other conflicts encountered by the developer. An alternative energy source which is "gathering team", 15

Geothermal energy as an 'al ternatl ve' source, 54

Geothermal energy: an industry appraisal, 69

Geothermal energy: legal problens of resource development, 105

Geothermal energy: prospects and limitations, 109

Geothermal exploration and development in the United states: a tax analysis under the internal revenue code, 117

Geothermal rights and problems of legislation in Japan, 122

Geotheraal Energy Research, Development, and Demonstration het of 1974. Oversight hearings: loan guaranties. Hear Ings before the Subcomiltee on Energy Research, Development, and Demonstration of the Committee on Sefence and Technology, U.S. House of Representatives, NInety-Fourth-Congress, First Session, 207

Geotherwal tax consideratlons and shelters, 229

Geothermal energy: an industry appral sal, 232

Geothermal energy exploration, research, and development. Report of the Committee on Interior and Insular Affairs. United States Senate, Ninety-Third Congress, Second Session to accompany S, 2465,280

Geothermal laws and regulations In the western United States, 296

Geothermal Energy Research, Developaent, and Commercial Demonstration Act of 1973; Geothermal Energy Research, Development, and Demonstration Act of 1974. Hearings before the Subcomittee on Energy of the Comittee on Sclence and Astronautics, U.S. House of Representatlves, Ninety-Third Congress, Second Session on H.R.11212 and H.R.14172, 300

Geothermal resources - operations on public, acquired and withdrawn lands; notice of proposed rulemaking, 346

Geothermal research, 399

Geothermal resources in California, 408

Geothermal resources, present and future denand for power, and legislation in the state of Wyoming, 410

Geothermal Steam Act of 1970; procedure to be followed in cleialng rights, 428

Geotheraal resource development; report to accompany S. 368,445

Geothermal steam act of 1970. Exploltation and

development of geothermal stean resources, 448

Geotheral steam leasing; hearings before Subcomittee on Minerals, Materials and Fuels on $S \cdot 23$ and $S \cdot 912$, March 12-22, 1970,465

Geothermal Stean Act of 1966 (S. 1674); memorendun of dI sapproval, 14 Nov 1966,466

Geothermal stean. 467

Geothermal power in Callfornia, a response to Senate Resolution No. 138, relating to the use of geothermal power for the transportation of water over the Techachap Mountalns, 468

Greider geothermal statement, based on testimony presented to Lt. Gov. Dymally Committee, 62

H.R. 14801, to promote the exploration and development of geothermal resources through cooperation between the federal government and private enterprise; text. 395

Hewall geothermal law, 255

Hearing on the ownership of geothermal team underlying Geysers. Geotherwal Kinetics Inc., plaintift, vs Union OIl Company of California, defendants, May 28, 1976,33

Highlights of energy related leglslation in the 93rd Congress. Prepared at the request of Henry $M$. Jackson, Chairman, Committee on Interior and Insular Affairs, United States Senate pursuant to S.Res. 45, 215

Idaho legl slature, 354

Impacts of energy resources removal from Federal and Indian lands, 282

Implenenting the federal geothermal steam act of 1970 429 (CONF-710571-)

Institutional and environmental aspects of geothermal energy development, 1

Institutional, business, and financlal aspects of the geothermal energy industry (abstract), 257

Interstate environmental problems: a guide to vater pollution and water scarcity, 317

Law and geothermal development in New Zealand, 116

Luw of Iceland as it affects geothermal development, 123 Leasing on public, acquired and withdrawn lands; revision of proposed rule, 347

Legal, Institutional, and envi ronmental, 79 (CONF-760222P1)

Legal aspects of geothermal energy development, 126

Legal issuss in the development of geopressuredgeothermal resources of Texas and Loulsiane Gulf Coast. 81 (CONF-760222-P5)

Legal Issues in the development of geopressured geothermal resources of Texas and Loulsiana Gulf coast (Summary), 31

Legal problems of the geothermal industry, 469

Legislative goals of electric companies in 1974, 264

Maximum and timely commercial development of domestic geothermal energy, 179

Mining and minerals policy: 1976 bicentennial edition, $42(N P-21355)$

Oversight hearings on Public Law 93-410: the Geotheral Energy Research, Development and Desonstration Act of 1974. Hearling before the Subcomittee on Energy Research, Development and Demonstration of the Comittee on Science and rechnology, U.S. House of Representatives, Ninety-Fourth Congress, Second Session, 103

Packwood geothermal blll (Senate Blll s. 3392), 259

Perspective for the 94 th Congress, 311

Preliminary report on legal and public polley setting for geothermal resource development in Hawali, 279

President's message on energy, 1973, 373

Project Independence. Final task force report geothermal energy, 250 ( NP-20944)

geothermal energy, 250 ( NP-2094
project Independence report, 287

Proposed rule naking: geothermal resources - leasing on public, acquil red and withdrawn lands: revision of proposed rule, 345

Protecting the environment, 102

Public and geology-related legisletion In California, $1968-1972,381$

$R$ and $D$ in generation: gluing practical direction to diverse views, 145

Recent developments in the taxation of geothermal exploration, 196

Recent developments In the taxation of geothermal exploration, 310

Recent developments in the taxation of geothermal exploration, 485

Recent geotheraal developments in Colorado, 174

Reducing the risks in geotheral exploration: tax update, 180

Report to the Congress. Problews in identifying, developing, and using geothermal resources, 189 (TID26866)

Research, development, and the energy crisis. Heeringe held November $20,1973,383$ 
Revlew of sone of the legal problems in geothermal development, 413

Role of the state Lands DIvision In developling geothermal resources in Callfornia, 70

8. 564 , to establish a Ive-year geothermal research progran: text; statement, 427

5. Con. Res. 29, to express the eense of Congress that the Bureau of Reclamation should accelerate ita investigations of geotheraal resources a potentlal a jor new cource of water. supplies for the western united states: text; statement, 424

S.1263, National Energy Research and Developnent Pollcy Act of 1973, 359

state policles for geothermal development, 85 (NSF/RA760230 )

State responses to the energy crisis, 301

Sumary and concluding remarks (Lecal aspects of geothermal resource development), 24

Sumary guide to the Institutional problems confronting the geothermel energy industry, 244 (CONF-741145-1)

sumary guide to the Institutional problems confronting the geothermal energy induatry, 283

sumary of Section XII: legal and Institutional aspecta, 107

Terms, conditions, standards, and eppllcation procedures for Initlal geotheral development: Imperial county. California, 351

The potential for energy production from geothermal resources: Report of the Subcomittee on Water and Power Resources, Comeittee on. Interlor and Insular Affelrs. United states senate, Nincty-Third Congress. First session, 324

U.S. Energy Resources Development Administration: Geothermal Loan Guaranty Progran, 228

U.S. energy $R$ and D: polley and priorlties, 294

U.S. taxes on energy resources, 183

Uitimate future of the geotherial energy law, 286

United states law as it affects geothermal developent, 115

United States geotheraal leglslation and environmental inpact for leasing, 390

Use of geothermal heat potential, 473

Witnesses for oll: the case against dismemberment, 130

LEGISLATION/HEARINGS

Senate Judiciary Comalttee HB 2040: April 30, 1975, oregon, 172

LICENS ING

Adminietrative laws of Callfornia' a State Land Commission: regulations pertalining to geothermal resources, 349

Appendix A: governance of geothermal energy development. 48 (JPL-5040-25(Rev.A)(App.))

Federal energy regulation: en organizational study, 262 (TID-26559)

Idaho Legislature, 354

Inat 1 tutional barriers to geothermal energy development Second report of the Institutional Barrier Panel to the Geothermal Advisory Councli, 134

Interrelationship between Federal, State and Local Regulatory Agencies, 355

Law and geothermal development in New Zealand, 116

Overview of the Callfornia peraltting process, 23

Role of the state Lands Division in developing geothermal resources in Callfornia, 70

Torms, conditions, standards, and applicetion procedures for Initlal geothermal development: Imperial county, Cailfornia, 351

LOAN GUARANTEES

Geothermal energy research, development, demonetration, and production: Federal guarantees on loans, 58

Geotheraal energy: an Industry appraisal, 69

Geothermal Federal loan guarantee progran (Federa) Register), 148

Geotheral tax consideration and shelters, 229

U.s. Energy Resources Development Admini itration Gootheraal Loan Guaranty Progran, 228

LDAN GUARANTEES/LEGAL ASPECTS

Geothermal Energy Research, Development, and Demonstration Act of 1974. Oversight hearings: loan guaranties. Hearings before the subconal ttee on Energy Rescarch, Development, and Demonatration of the Committee on Selence and Technology, U.S. House of Representatives, Ninety-fourth Congres,, first session, 207

LOCAL GOVERNMENT

Interrelationship between lederal, state, and local regulatory agencies on the development of the geotheral resource in Californla, 342

Some issues regarding regulatory poilcy, polltical particlpation, ind social implications of geothermal resource development in the Imperial Valley, 74 (NP21381)

Some Issues regarding regulatory pollcy, political partleipation, and social inpilcatlons of geothermal resource development in the Imperial Valley. 142

LOCAL GOVERNMENT/COOPERATION

Interrelationship between Federal, state and Local Regulatory Agencles (For exploration and exploltation of US geothermal resou rces), 355

LOUI SI ANA/GEOPRESSURED SYSTEMS

Legal issues in the development of geopressuredgeotheral resoures of Texas and Loulsiana Gulf Coast, 81 (CONF-760222-P5)

Proceedings of second geopressured geothermal energy conterence, Austin, Texes, February 23-25, 1976.

Volume $v$. Legal, Institutional, and environmental, 80 ( CONF-760222-P5)

\section{LOUISIANA/GEOTHERMAL WELLS}

Environmental issessment of proposed geothermal well testing in the TIgre Lagoon OII Field, Veralil on Parlsh, Loulsiana, 68 (TID-27034)

LOUISIANA/GOUERNMENT POLICIES

State policles for geothermal development, 85 (NSF/RA760230 )

$\mathbf{M}$

MANAGEMENT

Definition of an Institutional etructure (Susanville Geotheraal Energy Project), 35 (SAN-1077-4)

MANPONER

Engl neering manpower and energy needs. IV. Faderal pollcles have an Impact, 149

One third of the nation's land: report to the President and to the Congress by the Public Land Law Reviey Conmission, 452

MARKET

Continiung energy crisls In America, 210

Critical national cholce: new energy horizons...or horizontal disintegration, 104

Economic and social aspects of geothermal energy resource development, 128

Economlce of exhaustibie resources. I. The peculiar problems of ineral wealth, 482

Energy. Volume I. Demands, resources, Inpact, technology, and policy, 295

Energy and materials, 38

Energy company: monopoly trend in the energy warkets, 430 ( PB-218830)

Energy cononics, 56

Energy elf-sufficlency: how wuch; how soon, 216

Energy taxes and subsidies, 314

FEA: prices hold key to energy future, 63

Formation, funding, and development of a sall exploration company, 231

Geothermal vales contracts, 21

Geothermal Energy Research, Developwent, and Demonstration Act of 1974. Oversight hearings: loan guaranties. Hearings before the subcomittee on Energy Research, Development, and Demonstration of the Committee on Sclence and Technology, U.S. House of Representatives, Ninety-Fourth Congress, First Session, 207

Geotheraal energy: an Industry appraisal, 232

National program definition sudy for the non-electrical utillzation of geothermal energy, 173 (ANCR-1214)

Property aystems in geothermal resources: a critlque and recomendations, 118

Self-sufficlency in energy, 176

State responses to the energy crisis, 301

Status of conomics and linancing geothermal energy power production, 227

Structure of the geothermal industry through 1974, 238

Water and power erom geothermal resources in Calffornta. An overview, 313

MATERIALS/DEMAND FACTORS

Energy and materials, 384

MEETINGS

Compendium of first day papers presented at the First Conference of the Geothermal Resources Council, El Centro, Callfornla, Feb 1972, 412

Financial espects of geothermal resources development, San Francisco, Callfornla, October 23-24, 1975, 226

Geothermal Resources Development Institute conference. Salt Lake City, Utah, January 27-28, 1977, 9

Proceedings of second geopressured geothermal energy conference, Austin, Texas, February 23-25, 1976. Volume $V$. Legal, Institutional, and environmental, 80 (CONF-760222-P5)

Procedings of the geothermal power development conference, Univeraity of Callfornia, Berkeley, June 18, 1974, 271 (LBL-3099)

Proceedings: natlonal conference on geothermal energy Palm Springs, Callfornta, May 10-11, 1973. Volume II, 335 (NSF/RA/N-73-117(Vol -2))

Susanville Geothermal Energy Profect. Workshop proceedings elnal technical report, 0 (SAN-1077-4)

METALS/GOVERNMENT POLICIES

Mining and alnerals pollcy: 1976 blcentennial edition. 42 (NP-21355)

METHANE

Alternat fve sources of energy: practical technology and philosophy for a decentralized soclety, 213

MINERAL LEASING ACT

Development of geothermal resources and the 1970 Geothermal stean Act: law in search of definition, 318 MINERAL RESOURCES

Economics of the conmon pool: property rights in exhaustible resources, 439

Energy fuel mineral resources of the public lands. Volume VI: Legal tudy of coal resources on public lands geothermal resources on publlc lands. Interim report, 443 ( $\mathrm{PB}-196325$ )

Energy fuel eineral resources of the public lands. 
Volume I. Master report: atudy prepared for the Public Land Law Review Comal ssion, 453

Geothermal resources in Callfornia, 470

One third of the nation's land: report to the President and to the Congress by the Publlc Land Lav Review Comis asion, 452

Public hearing on geotheral energy and assocleted -I neral resources, 475

Some issues regarding regulatory policy, polltical particlpation, and social inplications of geothermal resource development in the Imperial Valley, 74 (NP21381)

vi etory Sand and Concrete, Inc. va Comml esioner of Internal Revenue, January 2, 1974, 319

MINERAL RESOURCES/EXPLOITATION

Economics of exheustible resources. I. The pecullar problems of wineral weal th, 482

MINERAL RESOURCES/GOVERNMENT POLICIES

Hearing on the ownarship of geotherad stean underlying Geysors. Geotheraal Kinetics Inc., plaintlft, vs Union Oil Company of California, defendants, May 28 , 1976,33

MINERAL RESOURCES/HEARIMGS

Hearing on the ownership of geothermal stean underlying Geysers. Geothermal Kinetics Inc., plaintiff, vs Union 011 Company of Callfornia, defendants, May 28 ,

IMERAL RIGHTS

Acquieltion of geothermal rights: proposed methods, 478 Analysis of the usual of 1 and gas lease provlsions, 479

Development of geothernal resources and the 1970 Geotheraal Steam Act: law in search of definition, 318 Geothermal steam Act of 1970,440

Property theorles affecting the lendowner in a new of and gas producing state, 480

MINERALS/DEPLETION ALLOWANCÉS

Internal Revenue Service Regulations (Mineral depletion allowances for tax purposes), 458

vict ory Sand and Concrete, Inc. vo Commi ssioner of Internal Revenue, January 2, 1974 (Mineral depletion allowances for sand and gravel under publle land leases, 26CFR611(a); 26CFR613), 319

MINERALS/GOVERNKENT POLICIES

Mining and minerals polley: 1976 bicentennial edition, 42 (NP-21355)

MINERALS/LEGAL DEFINITIONS

Development of geothermal resources and the 1970

Geothermal Stean Act: law in search of definition, 318

Salt water is alneral: ownership of a natural resource of increasing importance in oll-producing states, 417

MINERALS/OWNERSHIP RIGHTS

Property theorles affecting the landowner in a new oil and gas producing state, 480

MINING

See also COAL HINING

MINING/GOVERNMENT POLICIES

Minlng and ainerals poliey: 1976 bicentennial edition, 42 (NP-21355)

MINING LaUS

Law of o1l and gas, 441

MONT ANA/ENERGY DEMAND

Mont ana energy polley study, 202

MONTANA/ENERGY SOURCES

Financing infrastructure in energy development areas in the West. Proceedings of a conference held August 21 and 22,1975 , in Snowbird, Utah, 218

Montana energy policy study, 202

MONTANA/GOVERNMENT POLICIES

State policies for geothermal development, 85 (NSF/RA760230 )

MONTANA/US ORGANIZATIONS

A brief outline of geothermal regulatory agencies in the western United States, 304

MONTANA/WATER RESOURCES

Western states water requirenents for energy development to 1990,249 (NP-20555)

NASA

(Natlonal Aeronautles and Space Administration.)

NASA/RESEARCH PROGRAMS

Federal organlzation for nonnuclear energy research and development activities of departments and agencies other than ERDA: FY 1976, 175 (NP-20699)

NATIONAL DEFENSE

nergy crisis: revision in U.S. polley to preserve nat.lonal security, 330 (AD-778886)

NATIONAL ENVIRONMENTAL POLICY ACT

Environmental laws and regulatlons, 166 (JPL-5040-6(Vol. 3))

United states law as it arfects geothermal development,

NATIONAL SCIENCE FOUNDATION/RESEARCH PROGRAMS

Federal organization for nonnuclear energy research and development activities of departments and agencies other than ERDA: FY 1976, 175 (NP-20699)

NSF/RANN FY 1975 progran for geothermal resources research and technology, 187
NATURAL GAS

Continuing onergy crisls In America, 210

NATURAL GAS/GOVERMMENT POLICIES

Mining and einerals polfcy: 1976 bicentennial edition, 42 (NP-21355)

The energy crisis and proposed solutions. Panel diecussions before the Comulttee on Ways and Means. House of Representatives, Ninety-Fourth Congress, First session on the energy crists and proposed solutions, part 3 of 4,201

NATURAL GAS/LAWS

Evolution of oll and gas law, 481

NATURAL GAS/LEASES

Law of oll and gas, 441

NATURAL GAS/RECOVERY

Analysis of the potential use of geothernal energy for power generation along the Texas Gule coast, 150 (NSFRA-N-74-246)

NATURAL GAS/REGULATIONS

Highlights of energy related legislation in the 93rd Congress. Prepared at the request of Henry $M$. Jackson, Chai raan, Comin It tee on Interior and Insular Affalrs, United States Senate pursuant to S.Res. 45, 215

NATURAL GAS INDUSTRY/ECONOMICS

FEA: prlces hold key to energy future (New natlonal energy outlook), 63

NATURAL GAS INDUSTRY/FORECASTING

Energy economl cs, 56

NATURAL GAS INDUSTRY/GOVERNIENT POLICIES

Energy economl cs, 56

NATURAL GAS INDUSTRY/LAWS

Law of oll and gas, 441

Property theories affecting the landowner in new ofl and gas producing state, 480

NATURAL GAS INDUSTRY/LEASES

Analysis of the usual ofl and gas lease provisions, 479

NATURAL GAS INDUSTRY/LEGAL HISTORY

Evolution of oll and gas law, 481

NATURAL GAS INDUSTRY/PLANNING

Indians cautious on development, 32

NATURAL GAS INDUSTRY/REGULATIONS

Energy regulation by the Federal Power Comission, 316

NATURAL GAS WELLS/ENUIRONMENTAL IMPACTS

mpacts of energy resources removal from federal and Indi an lands, 282

NATURAL RESOURCES/EXPLOITATION

Economics of the conmon pool: property rights in exhaustible resources, 439

NATURAL RESOURCES/OWNERSHIP RIGHTS

Economics of the common pool: property rights in exhaustible resources, 439

NATURAL STEAM

(Use ror geothermal stean that contains Incondensible gases (typlcally $\mathrm{CO}_{2}$ and $\mathrm{H}_{2} \mathrm{~S}$ ) with minor anounts of other gases.)

NATURAL STEAR/CONTRACTS

Geotheraal sales contracts, 21

NATURAL STEAM/COST

Geothermal steam pricing at the Geysers; Lake and Sonom Counties, California, 100

NATURAL STEAM/DEPLETION ALLOWANCES

Reich, A.E. et al. va Commissloner of Internal Revenue and G.D. Rowan t al. vs Conmissioner of Internal Revenue. U.S. Court of Appeals, Ninth Circult. January 21, 1972 (Judicial interpretation of IRS tax regulations relative to depletion allowance for geothermal well drilling and development; 26 CFR 1. $263(\mathrm{c}), 1.611(\mathrm{a})$, and $1.613(\mathrm{~b})), 416$

NATURAL STEAH/HEARINGS

Disposition of geothermal steam - 1967, 464

NATURAL STEAM/LEGISLATION

Authorlzing the Secretary of the Interlor to nake disposition of geotheraal steam and associated geothermal resources report to accompany's. 368,444 Di sposition of geotheral stean - 1967, 464

NATURAL STEAM/OWNERSHIP

Hearing on the ownership of geothermal team underlying Geysers. Geothermal Kinetics Inc., plaintitr, vs Union Oil Company of California, defendants, May 28, 1976,33

NATURAL STEAM/OWNERSHIP RIGHTS

Geothermal steam poses ownership questions, 454

NEPA

SEe NATIONAL ENUIRONHENTAL POLICY ACT

NET ENERGY

(DIfference of energy output and energy input.)

NET ENERGY/ENERGY SOURCES

Energy analysis and public polley, 155

NEVADA/ENERGY SOURCES

Financing infrastructure in energy development areas in the West. Proceedings of a conference held August 21 and 22,1975 , in Snowbird, Utah, 218

NEVADA/GEOTHERHAL EXPLORATION

Geothermal exploration and development in Nevada, 409

NEVADA/GEOTHERMAL RESOURCES

Nevada's geothermal resources, 457

NEVADA/GOVERNMENT POLICIES

state policles for geothermal development, 85 (NSF/RA760230 )

NEVADA/US ORGANIZATIDNS

brief outline of geothermal regulatory agencies in the vestern Und ted States, 304

NEVADA/UATER RESOURCES 
Intergtate environmental problens: a guide to water pollution and water scarcity, 317

Western states water requirements for energy development to $1990,249(N \mathrm{P}-20555)$

NEU MEXICO/ELECTRIC POWER

Some Interfaces in resource utllization (Geotherma) energy, energy transulesion, and desalination of underground water In New Mexico), 484 (LA-UR-73-570)

NEH MEXICO/ENERGY SOURCES

Financing infrastructure In energy development areas in the West. Proceeding of anference held Auguat 21 and 22,1975 , in Snowbird, Utah, 218

NEW MEXICO/GEOTHERMAL ENERGY

Some interfaces in resource utllization (Geothernal energy, energy transal estion, and desal ination of underground water in New Mexle0), 484 (LA-UR-73-570)

NEW MEXICO/GOVERNMENT POLICIES

state pollcies for geotheraal development, 85 (NSF/RA760230 )

NEW MEXICO/US ORGANIZATIONS

A brief outline of geotheral regulatory agencles in the vestern United States, 304

NEU MEXICO/WATER RESOURCES

Uestern states vater requirenent for energy development to 1990,249 (NP-20555)

NEY YORK CITYTUATER RESOURCES

Weter supply: economics, technology, and polley (Book), 455

NEU ZEALAND/GEOTHERMAL ENERGY

Law and geothermal development in New Zealand, 116

MEU ZEALAND/LEGI SLATION

Lay and geothermel development in Nev Zealend, 116 NEW ZEALAND/RECREATIONAL AREAS

Possible conflict between the interesta of tourisi and geothermal power development, 227

NEU ZEALAND/REGULATIONS

Rotorua City (New Zealend) regulations on geothermal energy, 265

NOISE POLLUTION ABATEMENT

Geotheraal Environiental Advisory Panel. Second annual report, July 1, 1975-June $30,1076,136$

Geothermal Environmental Advisory Panel. First annual report, June 1, 1974-June 30, 1975, 225

Geothermal resources operati onal Order No.

environmental protection requirements, 237 genera.

Geothermal Steam net of 1970. Public Law 91-581

Senate Res. 368, 91st Congress, Decenber 24, 1970, 391

NORTH DAKOTA/ENERGY SOURCES

Financing Infrastructure in energy development areas in

the Hest. Proceedings of conference held August 21 and 22,1975 , In snowbird, Utah, 218

NORTHERN IRELAND

See UNITED KINGDON

NUCLEAR ENERGY/FINANCING

Financing infrastructure in energy development areas in the West. Proceedings of a conference held August 21 and 22,1975 , in Snowbird, Utah, 218

MUCLEAR ENERGY/PLANNING

Longer-range technologleal potentlals for energy development: an asessment of the prospects in new energy technology, 405

NUCLEAR FUELS

Continuing energy crisis in America, 210

NUCLEAR FUELS/PROCESSING

Protecting the environeent (Chepter in Encyelopedia of Energy), 101

NUCLEAR FUELS/PRODUCTION

Protecting the environment (Chapter in Encyclopedia of Energy), 102

NUCLEAR POWER/PLANNING

Public policy toward environment 1973: review and

appralsal. Nucleer and other energy, 368

OIL SHALES

Continulng energy erisis in America, 210

Proceedings of citizenge forum on potential cuture energy sources held at Portland, Oregon, January 17. 1974,223

DIL SHALES/GOVERNMENT POLICIES

Mining and uineral pollcy: 1976 bicentennial edition, $42(N \mathrm{P}-21355)$

OIL WELLS

See al so PETROLEUM

OIL WELLS/ENUIRONHENTAL IHPACTS

Impact of energy resources removal 1 rom Federal and Indien lands, 282

OKLAKOMA/ENERGY POLICY

Energy in Oklahoma. Volume one. Final report of Oklahoma Energy Advi sory Council, Februery 1, 1974, 276 ORBITAL SOLAR POWER PLANTS

Natural resources development and pollcles, Including envi ronmental conalderations, 437

OREGON/GEOTHERMAL EXPLORATION

Sunner Lake Basin geotheras lessing: Environental Anelyst : Record, 51 (KP-21256)

ORECON/GEOTHERMAL RESDURCES

Adalnistrative requl rements for developsent of geotheral resources, 157

Gaothernal resources. Part I and II. Hearings before the subconittee on Uater and Pouer Resources of the
Committee on Interior and Insular Affairs, United

states Senate, Ninety-Third Congress; First session, 297

Paclfle Northwest geothermal: review and outlook, 61

Senate Judlclary Comiltee HB 2040: April 30, 1975. Oregon, 172

OREGON/GOVERNMENT POLICIES

state pollcles for geothermal development, 85 (NSF/RA$760230)$

OREGON/REGULATIONS

Append Ix B: administrative requilrements for development of geothermal resources, 49 (JPL-5040-25(Rev.A)(APp.)) OREGON/US ORGANIZATIONS

A brief outline of geothermal regulatory agencies in the western United States, 304

OREGON/UATER RESOURCES

Western otates water requil rements for energy developent to 1990,249 (NP-20555)

ORGANIZATIONAL MODELS

Definition of an institutional structure (Susanville Geotheraal Energy Project), 35 (SAN-1077-4)

OWNERSHIP

Legal Issues in the development of geopressuredgeothermal resources of Texas and Loulstana Gulf coast, 81 (CDNF-760222-P5)

OWNERSHIP RIGHTS

Acquisftion of geothermal rights: proposed methods, 478 Analysis of the usual ofl and gas lease provisionsi 479

Appendix A: governance of geothermal energy development, 48 (JPL-5040-25(Rev.A)(App.))

Benefits and costs to Iandowners from geothermal resource lease and development, 140

Development of geothermal resources and the 1970 Geothermal steas Act: law In search of definition, 318

Economics of the common pool: property rights in exhaustible resources, 439

Environmental Impacts of geothermal resource development on commercial agriculture: case study of land use confllet, 131

Evolution of oll and gas law, 481

Geothermal steas Act of 1970,440

Geothermal team poses ownership questions, 454

Law of I celand as it afrects geothermal development, 123

Property systems in geothermal resources: a citique and recomendations, 118

Property theorles affecting the landowner In a new ofl and gas producing tate, 480

Salt water is mineral: ownership of a natural resource of increasing laportance in oll-producing states, 417

Some apects of property rlghts, 472

Summary of Section XII: legal and institutional aspects,

Tovard a theory of property rights, 460

OWNERSHIP RIGHTS/LEGAL DEFINITIONS

United states of Amerlca vs. Unlon oli Conpany of California. U.S. Distriét Court, N.D. Callfornia Clv. No. 72-1866 GBH. Menorandum of Decision, 372

OWNERSHIP RIGHTS/LEGAL DEFINITIONS

Unlted states of America $v$ s Union 011 Company of Callfornia. U.S. Diatriet Court, N.D. Callfornla Clu. No. 72-1866 GBH (Ownership righte of geothermal team and resources from public land leases; Stock Raling Homestead Act), 389

PATENTS/government POLICIES

Sunmary of ERDA patent pollcy relevant to geothermal energy, 165 (JPL-5040-6(Vol.3)) PETROLEUH

SEe 1 :0 OTL UELLS SHALE OIL

Continuling energy crisis in Amerlea, 210

PETROLEUM/ALLOCATIONS

HIghlights of energy related legislation in the 93rd Congress. Prepared at the request of Henry $M$.

Jackson, Chalrman, Commlttee on Interior and Insular Afralra, United states Senate purvant to S.Res. 45, 216

U.S. texes on energy reeources, 183

PETROLEUM/ECONOMIC POLICY

U.S. taxes on energy resources, 183

PETROLEUM/ENERGY POLICY

Energy In soclety (Worldwide poliey distribution and devel opment ), 370

PETROLEUH/GOVERNMENT POLICIES

Mining and aineral policy: 1976 blcentennial edition, $42(\mathrm{NP}-21355)$

The energy crisi and proposed solutions. Panel discusilons before the Comblttee on Hays and Heans. House of Representatives, Ninety-Fourth Congress, Firet seseiton on the energy crisis and proposed colutiona, part 3 of 4, 201

PETROLEUM/LAWS

Evolution of oll and gas $1 \mathrm{au}, 481$

PETROLEUM/LEASES

Law of ofl and gae, 441

PETROLEUH/RESERVES

Highilghts of energy related legislation in the 93rd 
Congress. Prepared at the request of Henry $M$. Jackson, Chalrman, Committee on Interior and Insular Affairs, United States Senate pursuant to S.Res. 45, 215

U.S. taxes on energy resources, 183

PETROLEUM INDUSTRY

Natural resources development and pollcies, including envi ronmental considerat lons, 437

PETROLEUM INDUSTRY/ANTITRUST REVIEW

Critical nat lonal cholce: new energy horizons...or horizontal disintegration (Booklet), 104

Hitnesses for oll: the case against dismemberment (Book, collecting statements of 19 witnesses), 130

PETROLEUM INDUSTRY/ECONOMI CS

FEA: prices hold key to energy ruture (New national energy out look), 63

PETROLEUM INDUSTRY/FINANCING

Financing infrastructure in energy development areas in the West. Proceedings of a conference held August 21 and 22,1975 , in Snowbird, Utah, 218

PETROLEUM INDUSTRY/LAWS

Law of ofl and gas, 441

Property theories affecting the landowner in a new ofl and gas producing state, 480

PETROLEUM INDUSTRY/LEASES

Analysis of the usual oil and gas lease provisions, 479

PETROLEUM INDUSTRY/LEGAL HISTORY

Evolution of ofl and gas law, 481

PETROLEUH INDUSTRY/LEGISLATION

Uitnesses for ofl: the case against dismemberment (Book, collecting statements of 19 witnesses), 130

PETROLEUH INDUSTRY/OPERATION

Critical national cholce: new energy horlzons....or horizontal disintegration (Booklet), '104

PETROLEUM INDUSTRY/PLANNING

Indl ans caut lous on development, 32

PETROLEUM REFINERIES /OPERATION

Critical national cholce: new energy horlzons...or

horizontal disintegration (Booklet), 104

PI PELINES

See al so ALASKa OIL PIPELINE

PIPELINES/CONSTRUCTI ON

Geothermal resources operational Order No. 6: pipelines and curface production facilities, 26

PIPELINES/ENUIRONMENTAL IHPACTS

Geothermal resources operational Order No. 6: pipelines and surface production facllities, 26

PLANTS (INDUSTRIAL)

See INDUSTRIAL PLANTS

POLLUTION LAYS

Geothermal world directory, 376

POLLUTION REGULATIONS

Environmentally sensitive land use regulation in California, 357

Geothermal energy: an industry appraisal, 69

Geothermal resources operational (GRO) Order No. 4 for central and western regions, 168

Geothermal Environmental Advisory Panel. First annual report, June 1, 1974-June 30, 1975, 225

Inst itutional barriers to geothermal energy development. A report by the Institutional Barrier Panel to the Geothermal Advisory Council, 135

Legal, Institutional, and political problems in producing electric power from geothermal resources in California, 144

POOLING

Economics of the common pool: property rights in exhaustible resources, 439

POPULATION DYNAMICs

Development of geothermal energy in the Gulf Coast: socio-econonic, denographic, and political considerat lons, 82 (CONF-760222-P5)

POWER GENERATION/ENVIRONMENTAL EFFECTS

Protecting the environment (Chapter in Encyclopedia of Energy ), 101

POWER GENERATION/FINANCING

Financing infrastructure in energy development areas in the West. Proceedings of a conference held August 21 and 22,1975 , in Snowbird, Utah, 218

POWER GENERATION/GEOTHERKAL ENERGY

Geothermal: as we see it today, 253

POWER GENERATION/HEARINGS

Statement at hearings before the Comalttee on Interior and Insular Affalrs (Four Corners Area), 433

POWER GENERATION/PLAMNTNG

Englneering anpower and energy needs. IV. Federal pol leles have an Impact, 149

POWER GENERATION/RESEARCH PROGRAMS

$R$ and $D$ in generation: giving practical direction to di verse views, 145

POWER POTENTIAL

Geothernal resources. Hearlings before the subconittee on Water and Power Resources of the Comnittee on Interlor and Insul ar Afralrs, United States Senate, Winety-Third Congress, First session on the potential for the production of power from geothermal resources, 284

POWER TRANSMISSION

Natural resources developaent and polleles, including environmental considerations, 437

PRODUCT ION

(Limited to industrial production; see also PARTICLE
PRODUCTION.)

Geothermal resources operational Order No. 7 : production and royal ty measurement, equipment, and testing procedures, 27

test ing procedures
PROJECT INDEPENDENCE

Energy self-sufficlency: how much; how soon, 216 Geothermal energy: potentially the Hest "s ajor energy resource (Project Independence hearings), 247

Project Independence.. Final task rorce report: geothermal energy, 250 (NP-20944)

Project Independence. A proposed program for U.S. energy self-sufficiency by 1980,275

Project Independence report, 287

Project Independence Blueprint: IInal task force report. Geothermal energy, 288

U.S. taxes on energy resources, 183

PROJECT INDEPENDENCE/GEOTHERMAL ENERGY

Econonic and engineering Inplications of the Project Independence 1985 geothermal energy output goal and the associated sensitivity analysis, 96

PROJECT INDEPENDENCE/HEARINGS

Project Independence Blueprint: transcript of geventh public hearing, Houston, Texas, September 16-20, 1974, 298

PROJECT INDEPENDENCE/IMPLEMENTATION

National plan for energy research, development and demonstration: creating energy cholces for the ruture. Volune 2. Program implementation, 84 (ERDA-76-1(Vol.2)

PROJECT INDEPENDENCE/REVIEWS

Review of Project Independence Blueprint panel subcommittee reports on FEA-interagency task porces. Report on CTAB recommendations for a national energy program. Subcomittee working documents, 198 (COH-75$10500)$

Review of the Profect Independence report submitted to Office of Energy Research and Development, National Sclence Foundation, January 10, 1975, 195 ( PB-238791)

PROPERTY RIGHTS/SOCIO-ECONOHIC FACTORS

Some aspects of property rights, 472

Toward a theory of property rights, 460

PUBLIC LANDS

Economics of exhaustible resources. I. The pecullar problems of mineral weal th, 482

Environmental impact staterent for the Geothermal

Leasing Program, 392

Federal Geothermal steam Act of 1970: Public Law 91-581, 344

Federal governaent leasing and operating regulations and environmental impact statements, 414

Geothermal stean act of 1965 (a bill to authorize the Secretary of the Interlor to make disposition of geothermal stean and assoclated geothermal resources). 474 (PD-218830)

Geothermal leasing practlces, 12

Geothermal resource development process, 47 (JPL-504025(Rev.A)(App.))

Geotheraal resources leasing: general, 320

Geothermal resources: leasing on public, acquired, and withdrawn lands, 321

Geothermal Stean Act of 1970,440

Hawa 11 geothermal law, 255

Law of Iceland as it affects geothermal development, 123

Lease of federal geothermal energy: rocky road (abstract), 34

Leasing of Federal geotheraal resources, 242 (NSF/RA/N74-159)

Leasing on public, acquired and withdrawn lands; revision of proposed rule, 347

Legal aspects of geothermal energy development, 126

Maximum and timely commercial development of domestic geothermal energy, 179

One third of the nation's land: a report to the President and to the Congress by the Public Land Law Review Commission, 452

Overview of the California peraltting process, 23

Recent geothermal developments in Colorado, 174

Role of the U.S. Geological Survey in assessing the Nation's geotheral energy resources, 239 (NSF/RA/N-74159)

Role of the state Lands Diviat on in developing geothermal resources in Callfornia, 70

Some aspects of property rights, 472

Summer Lake Basin geothermal leasing: Environmental Analysis Record, 51 (NP-21256)

Toward a theory of property l ghts, 460

United States of Amerlca vs Union oil 1 Company of California. U.S. District Court, N.D. California Civ. No. $72-1866 \mathrm{GBH}, 389$

Victory Sand and Concrete, Ince va Comalssloner of Internal Revenue, January 2, 1974, 319

Water supply: economics, technology, and policy, 455

PUBLIC LANDS/COAL RESERVES

Energy fuel mineral resources of the public lands. Volume VI: Legal study of coal resources on public lands: geothermal resources on public lands. Interia report, 443 (PB-196325)

PUBLIC LANDS/ENERGY SOURCE DEVELOPKENT

Iapacts of energy resources removal from Federal and Ind $I$ an $l$ ands, 282

PUBLIC LANDS/GEOTHERMAL EXPLORATION

Geothermal exploration on public lands: when and under what conditions, 337

PUBLIC LANDS/GEOTHERMAL RESOURCES

Acquisition of geothermal rights: proposed methods, 478 
Adninistratlve laws of Calltornia"s state Land Comission: requlations pertaining to geothermal resources, 349

Energy fuel aineral resources of the public lands. Volume VI: Legal study of coal resources on public lands: geotheraal resources on public lands. Interie report, 443 (PB-196325)

PUBLIC LANDS/GOVERNMENT POLICIES

Energy fuel aineral resources of the public lands. Volume I. Mater report: atudy prepared for the Public Land Law Review Comilsion. 453

PUBLIC LANDS/LAND LEASING

Environmental planning for the geothermal leasing program on publle lands, 285

Geothermal Leading Program. Volume III. Appendices A through H. Proposed geothermal, leasing, and operating regulations. Final environmental Impact tetement, 328 (E1s-CA-73-1681-F-3)

Geothermal resources leasing and operations on public, ecquired, and 1 thdrasn Iands. PP, 423

Proposed rule aaking: geothermal resources - leasing on public, acquitred and withdrewn lands; revist on of proposed rule, 345

Role of public lands In gootheraal energy, 199 (CONF750612-)

Rules and regulations relating to geothermal leases on Colorado state owned lands, 292

structure of the geothermal industry through 1974, 238

PUBLIC LANDS/LEGAL ASPECTS

Role of public lands in geothermal energy; 199 (CONF$750612-)$

PUBLIC LANDS/LEGISLATION

Callfornia public resources code: states pertalning to geotheraal resources, 348

PUBLIC LANDS/MANAGEMENT

Geothermal energy and the law. I. The federal lands management program, 224

Inst itut lonal barriers to geothermal energy development. A report by the Institutional Barrier Panel to the Geotheral I Advisory Counc II, 135

PUBLIC LANDS/MINERAL RESOURCES

Energy fuel al neral resources of the public lands. Volume VI: Legal tudy of coal resources on public lands; geothermal resources on publle lands: Interin report, 433 (PB-196325)

Energy fuel mineral resources of the public lands. Volume I. Master report: etudy prepared for the Public Land Law Review Comalssion, 453

PUBLIC LANDS/REgULAT IONS

Adainistrative laws of California's state Land Comission; regulations pertaining to geothermal resources, 349

Geothermal resources - operations on public, acquired and withdrawn lands; notlce of proposed rulemaking, 346 PUBLIC LANDS/WELL DRILLING

California public resources code: statutes pertaining to geothermal resources, 348

PUBLIC OPINION

Cosmunity planning, 164 (JPL-5040-6(Vol.3))

OpInion about geothermal development In Imperial county, California, 1976. Final report, 7

Public opinion concerning geothermal development in lake County, Callfornla, 65 (LBL-4447)

Public opinion in Cobb Valley concerning geothermal developant in lake County Calfeornis 50 (LBL-5204)

Results of an opinion survey on the 1977 budget proposel of the Energy Reseerch and Development Administration. Printed at the request of Henry M. Jackson, Chal rman. Comalttee on Interior and Insular Affalrs, United States Senate, 86

Some (ssues regarding regulatory polley, polltical particlpation, and soclal implications of geothermal resource development In the Imperlal Valley. 74 (NP21381)

some issues regarding reguletory pollcy, political participation, and social Implications of geothermal resource devilopment in the Imperial Valley, 142

\section{PUBLIC RELATIONS}

Benefits and costs to landowners trom geothernal resource loase and development, 140

Financing infrastructure in energy devalopment areas in the West. Proceedings of conference held August 21 the West 1975 . In Snowb of a confere

Inpacts of energy resources removal froa federal and Indian lands, 282

OpInion bout geotheraal development in Imperial county, Callfornia, 1976. Final report, ?

Publ lc opinion concerning geothermal developaent in Lake County, Californla, 65 (LBL-4447)

Public oplinion in Cobb Valiey concerning geothermal development in Lake County, Californta, 50 (LBL-5204)

Some Issues regarding regulatory polfcy, polftical participation, and social implications of geothermal resource development in the Imperial Valley, 74 (NP21381)

Sone lesues regarding regulatory polley, political perticipation, and social Implications of geothermal resource development in the Imperial Valley, 142

PUBLIC UTILITIES

Appendix A: governance of geotheral energy development, 48 (JPL-5040-25(Rev.A)(APP. ))

Costs of geothermal energy development. Final report, January 1977,3

Electilcutilitiea, 163 (JPL-5040-6(Vol.3))
Energy regulation by the Federal Power Conmlssion, 316 ERDA authorization, Fiscal Year 1977. Pert IV. Baste energy sctences. Heartings before the subcomittee on Energy Reacarch, Development and Demonstration of the Committee on Science and Technology, U.S. House of Representatives, Ninety-Fourth Congress, Second Seasion, February 26, 1976, 129

Geothermal energy in Californie: status report, 44 (JPL5040-25(Rev.A) (App.))

Geotherwal team pricing at the Geysers, Lake and sonome Countles, Callfornia, 200

Geothermal energy and the law. 1. The foderal lande management program, 224

Institutlonal barriers to geotherwal energy development. A report by the Institutional Barrier Panel to the Geotherma 1 Advi sory Councll, 135

Proposed energy research and development program: fiseal year 1976/77. Callfornie Energy Resources Conservation and Development Comalesion, 73 (NP-21008)

Rol of iniclpalitles in geothermal resource development, 14

Susanville Geotheraal Energy Project. Workshop proceeding final technlcal report, 40 (SAN-1077+4) Susanville Geothermal Utllity syaten, 42 (SAN-1077-4) Utility participation in a geothermal energy source, 293

PUBLIC UTILITIES/DECISION MAKING

Susanville Geothermal Energy Project overview, 36 (SAN1077-4)

PUBLIC UTILITIES/GEOTHERMAL ENERGY

Electric utility companies and geothermal power, 98

Present plans for utilization of geothermal energy. 45 (JPL-5040-25(Rev.A) (App.)

PUBLIC UTILITIES/LEGAL ASPECTS

Calffornia public utilities comission., 146

PUBLIC UTILITIES/LEGISLATION

Legislative goals of electric companies in 1974, 264

PUBLIC UTILITIES/POUER GENERATION

Calleornia public utilities commsesione, 146

$\mathbf{R}$

REACTOR FUELS

SEe NUCLEAR FUELS

RECREATIONAL AREAS/GEOTHERHAL EXPLORATION

Possible conflict between the interests of touris and geothermal power development, 127

REFUSE

SE SOLID UASTES

REGULATIONS

\section{SEe 1 :0 POLLUTION REGULATIONS}

1977 guidebook to California taxes with apecial emphasis on relationship to Federal taxes, 25

A brief outline or geothermal regulatory agencles in the western United States, 304

A technology assessment of geothermal energy resource development, 184 (PB-246241)

Adminlstrative laws of Callfornla's state Land Commission; regulations pertaining to geothermal resources, 349

Administrative law of Californlais resources agency: portion or the directions for preparing environmental inpact reports, 350

Alternative sources of energy: practical technology and philosophy for decentrailzed society, 213

Appendix A: governance of geothermal energy development, 48 (JPL-5040-25(Rev.A)(APP.) )

Appendix B: administrative requirements for developaent or geotherwal resources, 49 (JPL-5040-25 (Rev.A X App.) )

Benefita and costs to landowners from geotheraal resource lease and development, 140

Californis public utilities commission., 146

Callfornia public resources code: statutes pertalining to geothermal resources, 348

Callfornia laws for the conservation of geothereal energy, an act to anend the heading of Chapter 4, and to add to Chapter 3, Division 3 , of the Public Resource Code, relating to geothermal resources, 463

Callfornia laws tor the conservation of geothermal energy (Chapter 1483, statutes of 1965), an act to add Chapter 4, DIvision 3, to the Public Resources Code, relating to goothermai energy and assoclated resources. 476

Contents of a geothermal lease: some suggestlons, 87

Critlcal netional cholce: new energy horizons...or horizontal disintegration, 104

Declsion statement of Secretary of Interior on geothermal resources program, 267

Development of the Nation's geothermal energy resources. II, 154

Development of geothermal laws and regulatlons, 302

Economic and social aspects of geotheral energy resource development, 228

EIR's: truth and consequences, 306

Electric power, fuels development, and protection of the environment: legislation introduced in the 91 st Congress, 451

Electric utilities, 163 (JPL-5040-6(Vol.3))

Energy and naterlais, 384

Energy conpany: aonopoly trend in the energy arkets, 430 ( $\mathrm{PB}-218830$ ) 
Energy economles, 56

Energy in Oklahoma Volube one. Final report of Okl ahoma Energy Advisory Counc 11, February 1, 1974, 276 Energy legislation. Report of the Subcomittee on Energy of the Committee on Sclence and Astronautics, U.S - House of Representatives, Ninety-Thi rd Congress, Second sesal on, 277

Energy polletes of the world: Venezuela, 221

Energy regulation by the Federal Power Comaission, 316

Energy eelf-suffteleney: how much; how soon, 216

Englneering canpower and energy needs. IV. Federal pollcies have an Iapact, 149

Envi ronmental laws and regulations, 166 (JPL-5040-6(Vol. 3))

Environmentel overview of geothermal resources development, 22

Envi ronmentaliy sensitive land use regulation in Calleornite, 357

FEA: prices hold key to energy future, 63

Federal energy regulation: on organizetional etudy, 262 (TID-26559)

Federal government leasing and operating reguletions and environiental Impact tetements, 414

Federal regulations and lease teras and their regulationship to atate lews and regulations, 303

Final environaentel statement for the geothermal leasing program. Volues I. Promulgation of leasing and operating regulations, 360 (NP-20212)

Final environmental statement for the geothermal leasing progran. Voluae I, 365

Final environmental tatenent for the geothermal leasing program. Volume III, 367

Final environmental statement for the geothermal leasing program. Volume IV, 368

Flow chart of eritical path in geothermal exploration, 343

Geothermal resource characteristics, exploration considerations, and property acquisition techniques, 270 (CONF-741145-3)

Geothernal Leasing Program. Volune I. Promulgation of leasing and operating regulations. Final envirommental Impact statement, 326 (EIS-CA-73-1681-F1)

Geothermal Leasing Program. Volune III. Appendices A through H. Proposed geothermal, leasing, and operating regulations. Final environnental iapact st atement, 328 (EIS-CA-73-1681-F-3)

Geothermal Leasing Program. Volune IV. Appendix I. Coments on draft impact etatement and proposed regulations. Final environmental impact otatement, 329 (EIS-CA-73-1681-F-4)

Geotheral resources, present and future denand for power and legislation in the state of Wyoning. Public information serles 1, 67 (NP-21229)

Geothermal leasing progran, considers lepact of leasing and operating regulations to inplenent the Geothernel steap Act of 1970 and leasing of 3 areas in Californita Draft environmental Impact tatement. 421 (PB-203102-D) Draft envi ronmental Impact statement, 421
Geothermal Leasing Program, 396 (PB-208954)

Geothermal Leasing Program, 396 ( PB-208954)

Geothermal leasing program (dratt environmental inpact statement), 431 (PD-218830)

Geothermal steam act of 1970 (exploitation and development of geothermal stean resources), 447 (PD218830)

Geothermal stean act of 1965 (a bill to authorize the Secretary of the Interior to make disposition of geothermal stean and associated geotheraal resources), $474(P D-218830)$

Geothermal resources operatlonal Order No. 7: product $I$ on and royalty measurement, equipment, and testing procedures, 27

Geothermal energy in Californie: status report, 44 (JPL$5040-25($ Rev.A) (APp.))

Geothermal resource development process, 47 (JPL-504025(Rev.A) (App.))

Geothermal energy research, development, demonstration, and production; Federal guarantees on loans, 58

Geothermal Federal loan guarantee program (Federal Register), 148

Geothermal resources operational (GRO) Order No. 4 for central and western regions, 168

Geothermal power: strangled by red tape, 169

Geothermal tax considerations and shelters, 229

Geothernal exploretion and development in the United States: tax analysis under the Internal Revenue Code, 230

Geothermal resources operational Order No. 1: exploratory operatlons, 234

Geothermal resources operational Order No. 2 : drilling, completion, and spacing of geothernal wells, 235

Geothermal: as we see it today, 253

Geothermal resources: legal and tax considerations, 291

Geothermal laws and regulations In the western United States, 296

Geothermal well drilling and completion practices in Callfornia including casing and abandonment programs and exanpl es of blowouts, 308

Geothermal resources leasing: general, 320

Geothermal resources: leasing on public, acquired, and II thdrawn lands, 321

Geothermal resources - operations on public, acquired and withdrawn lands; notice of proposed rulenaking, 346 Geotheral power, 374

Geothermal resources research, 375

Geothermal world directory, $40 \mathrm{~s}$

Geothermal resources leasing and operations on public, acquired, and withdrawn lands. II, 423

Governeent al leasing regul at lons, 290

Greider geothermal tatepent, based on testimony presented to Lt. Gov. Dymaily Comittee (Developaent of geotherial industry). 62

hawall vol cano energy, 336

Highlight of energy related legialation in the 93rd Congress. Prepered at the request of Henry $M$. Jackson, Chalrman, Committee on Interlor and Insular Affalrs, United states senate pursuant to S.Res. 45 , 215

Idaho Leglelature, 35

Inpact of tate and federal law on development of geotherual resources in Texas. Project $L / R-9$, final report, 254 (NSF-RA-N-74-244)

Impact of stat and federal law on development of geotheral resources In Texas, 299

Impacts of energy resources removal from Federal and Indi an lands, 282

Institutional and environmental problens in geotheral resource development, 243 (NSF/RA/N-74-159)

Institutional barriers to geothermal energy development. A report by the Instltutional Barrier Panel to the Geothermal Advisory Councl 1,135

Institutional, business, and financlel aspects of the geotheraal energy industry, 252

Institutional, bus iness, and financiel aspects of the geothermal energy industry (abstract), 257

Internal Revenue Service Regulations, 458

Interrelationship between rederal, state, and local regulatory agencies on the development of the geothermal resource in Callfornia, 342

Interrelationship between Federal, State and Local Regulatory Agencies, 355

Laws, regulations, and soclal constraints to the development of geotherial energy, 139

Laws, regulations, and social constraints to the development of geothermal energy, 139

Leasing of Federal geothermal resources, 242 (NSF/RA/N74-159)

Leasing on public, ecquired and ulthdrawn lands: revilition of proposed rule, 347

Legal, Institutional, and political problems in producing lectric power from geothermel resources in Callfornia, 144

Legal and Inatitutional factors. Geothermal research study in the Salton Sea region of Callifornia, 233

Legal asects of geothermal energy development, 126

Maximu and timely commerclal development of domestic geotheraal energy, 179

Multipurpose geothermal resource development: an overview, 114

Overview of the Calffornila permitting process, 23

PGandE's geothermal power piant in California: the Geysers, 307

Power from the Earth: geothermal energy, 411

Prelinlnary report on legal and public polley setting for geothermal resource development in Hawali, 279

President's message on energy, 1973, 373

Proceedings of the energy research priorities conference held at Berulck Academy. South Berulek, Maine, July 30Auguat 4, 1972, 483 (CONF-720742-)

Project Independence. Final task force report: geotheraal energy, 250 (NP-20944)

Public pollcy toward environment 1973: a review and appraisal. Nuclear and other energy, 358

Recent developaents in the taxation of geotheraal exploration, 485

Regulatory aspects of geotheraal energy development in the Salton SealI perial Valley Area, 186 (UCID-16807)

Regulatory, planning and polfcy aspects of geotheraal energy development in Imperial County, California, 4

Relch, A.E. et al. va Comilesioner of Interrial Revenue and G.D. Rowan et al. vs Comilesioner of Internal Revenue. U.S. Court of Appeals, Ninth Circuit. January 21, 1972, 416

Role of state government in the development of a geothermal resource, 369

Rotorua City (New Zeai and) regulations on geothermal energy, 265

Rules and regulations relating to geothermal leases on Coloredo tate ouned lands, 292

Selected portions of Callfornia state-wide geothermal regulations. Appendix $B, 305$

Some I ssues regarding regulatory pollcy, political participation, and social lapilcations of geotheraal resource developent in the Imperial Valley, 74 (NP21381)

Some losues regarding regulatory pollcy, political particlpation, and social implications of geotheras resource development in the Imperial Valley, 142

state policies for geothermal development, 85 (NSF/RA760230 )

State taxation of geothermal resources compared with state taxation of other energy ninerals, 133

structure of the geothermal industry through 1974, 238

Sumary guide to the institutional problems confronting the geothermal energy industry, 244 (CONF-741145-1)

summary report of the Cornell workshop on energy and the 
environment. Hearing pursuant to S. Res. 45, national fuels and energy pollcy study, U. S. Senate, February 22-24, 1972, 404

Terms, conditions, standards, and application procedures for initlal geotheraal development: Imperial County, Callfornla, 351

Toward a national energy pol ley, 356

U.S. Energy Resources Development Adninistration: Geotheraal Loan Guaranty Progran, 228

United states law as it affects geotheraf developnent, 115

victory sand and Concrete, Inc. ve Commisioner of Internal Revenue, January 2, 1974, 319

Water conflicts fron the viewpolnt of regulator, 16

Western states water requirements for energy development to 1990,249 (NP-20555)

REGULATORY ÁGENCIES/COOPERÁTION

Interrelat longhlp between Federal, state and Local Regulatory Agencies (For exploration and exploltation of US geothermal resources), 355

RESEARCH PROGRAMS

See l 1 :0 DEHONSTRATION PROGRAMS

Geothermal energy resource utilization program planning. 66 (MTR-7137)

Geothermal nergy progras. Subpanel report VIII used in prepering the AEC Chalrman's report to the President, 325 ( WASH-1281-8)

Geothermal energy exploration, research and development. Senate report No. 93-849, 261

Geothermal resources research (Needed besic and applied areas), 375

Geothermal resources research, 394

Geothernal researeh, 399

Geothermal power in Californla, a response to senate Resolution No. 238 , rolat Ing to the use of geothermal power for the transportation of water over the Techachap Mountains, 468

Government activity report on geothermal energy In Japan, 122

Laus, regulations, and ooclal constraints to the development of geotherwal energy, 139

National progran definition study for the non-electrical ut ilization of geothermal energy, 173 (ANCR-1214)

NSF/RAWN FY 1975 progran for geothermal resources

research and technology, 187

Procedings of the energy research priorities conference held at Berwick Acadeny, South Berwlck, Malne, July 30August $4,1972,483$ (CONF-720742-)

Prograt defintion for the development of geotheral energy. Volume I. Background and program definition sumary, 169 (JPL-5040-6(Vol .2))

Progran definition for the development of geothermal energy. Volune II. Program definition development rationale and subprogram descriptions, 160 (JPL-5040o( $\mathrm{Vol} .2)$

Program definttion for the development of geothermal energy. Volume III. Appendixes, 161 (JPL-5040-6(Vol.3 ))

Proposed energy research and development progran:

Iscal year 1976/77. Callfornia Energy Resources

Conservation and Development Commission, 73 (NP-21008)

Research and development, 46 (JPL-5040-25(Rev.A)(APP.))

RESEARCH PROGRAMS/BUDGETS

An nalysis identifying issues in the fiseal year 1976 ERDA budget, 191 (PB-244863)

RESEARCH PROGRAMS/LEGI SLATION

5. 664, to eatabli sh tive-year geothermal research progran; text; tatement, 427

RESOURCE CONSERUATION/ECONOMICS

Economics of the comon pool: property pights in exhaustlble resources. 439

RESOURCE DEPLETION/ECONOMI CS

Economles of exhaustible resources. I. The peculiar problems of mineral wealth, 482

RESOURCE DEPLETIDN/GOVERNMENT POLICIES

Economics of exhaustible resources. : I. The pecullar problems of mineral weaith, 482

REVIEUS

1974: the geotheral year in retrospect, 182

Earth's heat tapped for geotheral power development, 420

Energy from geothermal resourees. Report prepared for the Subcommittee on Energy of the Committee on Science and Astronautice, U.S. House of Representatives,

Ninety-Thi rd Congress, Second Bession, 289

Geothermal enetgy: an industry eppralsa 1,76

Geothermal world directory, 89

Geotherwal energy, 90

Geothermal energy, 94

Geotheral world directory (1973), 376

Geothermal energy, It future and economica, 419

Introduction and legal overview of geothermal resources, 10

summary and concluding remarks (Legal apects of

geothermal resource development), 24

RISER CRACKING

SEe COAL LIQUEFACTION

\section{ROYALIIES}

Analyals of the usual ofl and gas lease provlsions, 479

Energy taxes and eubsidies, 314

Geotheral sales contracts, 21

Geotheraal regources operetional order No. 7 production and royel ty measurement, equipment, and

testing procedures, 27

Geothermal stean Act of 1970, 440
Guldelines relative to pipellnes and surface production equipment and to production and royalty measurement equipment, and testing procedures (Drder Nos. 6 and 7 ),

Institutional barriers to geothermal energy developaent. Second report of the Institutional Barrier Panel to the Geothermal Advisory Council, 134

SALTON SEA

Geothermal resources in Calltornia, 470

Regulatory apects of geothermal energy development in the Salton Sea/Imperial Valley Area, 186 (UCID-16807) SALTON SEA/GEOTHERMAL RESOURCES

Compendium of papers presented at the Iaperial Valley-Salton Sea area geothermal hearing. Det 22 and 23,450 Geothermal activity in 1971, 400 (PB-218830)

SALTON BEA GEOTHERMAL FIELD/LAND USE

Effects of geothermal development on the agricultural resources of the Imperial Valley, 6

SHALE OIL/RESEARCH PROGRAMS

5.1283, National Energy Research and Development Polley Act of 1973,359

SOCIAL IMPAC

Econonle Impact of geothernal energy development, 5

Federal role In geothermal resource development, 18

Laws, regulations, and social constraints to the development of geothereal energy, 139

Opinion about geothermal development in Iaperial county, Californie, i976. Final report, 7

Progran definition for the development of geothermal energy. Volume II. Program definition developaent rationale and subprogram descriptions, 160 (JPL-50406( $\mathrm{Yol} .2))$

Social Impilcations way arise with future geothermal usage, 93

Social implications that may arise with future geothermal use, 125

SOCIO-ECONOMIC FACTORS

See al to ECONOMIC IMPACT

A technology assesment of geothermal energy resource development, 184 (PB-246241)

Altefnate energy ources for Hawall. Proceedlngs of the vorkshop held May 8-9, 1975, In Honolulu, Hawail, 219

Boon touns may hinder energy resource development, 72 Community planning, 164 (JPL-5040-6(Vol.3))

Comparative analyais of the 1976 ERDA.plan and progran. 95

Definition of an institutional structure, 35 ( SAN-1077-4)

Development of geothermal energy in the Gulf Coest: soclo-economic, demographic, and political considerations, 82 (CONF-760222-P5)

Economic and socilal apects of geothermal energy resource development, 128

Economles of the common pool: property rights in exhaustible resources, 439

Economics of exhaustible reaources. I. The peculiar problems or mineral weal th, 482

Energy cholces and public pollcy, 158

Engineering manpower and energy needs. IV. Federal polleles have an Impact, 149

Environmental inpacts of geothermal resource development on comercial agriculture: case study of land use conelict. 131

Evolution of oll and gas law, 481

Geothermal development policy for an isolated atate the case of Hawail, 119

Geothermal steam Act of 1970. Publle Law 91-581, Senate Res. 368, 91st Congress, December 24, 1970, 391

Ieperial Valley environmental project, 59 (UCRL-52000-765)

Indians cautlous on developaent, 32

Institutional and environmental aspects of geothermal energy development, 2

Interstate environmentel problems: a gulde to water poliution and water ccarcity, 31 ?

Legal, Institutional, and polftical problens in producing lectric power from geothermal resources in Calleornia, 144

Multiaector enalysi of the impact of geothermal development on the econony of Imperial County. Call fornte, 28

Population analysi: relative to geothermal energy development, Imperlal County, Callfornia, 8

possible confilct between the interests of tourien and geothermal power development, 127

Proceedings of second geoprossured geothermal energy conference, Austin. Texas, Fobruary 23-25, 1976. Voluge $V$. Legal, institutional, and environental, 80 ( CONF-760222-P5)

Proceedings of the workshop on environmental aspects of geothermal resources development, 20-22 septesber 1974, $\mathbf{3 1 5}$

Public opinion concerning gootheral developeent in Lake County, Call fornle, 65 (LBL-4447)

Social Implications may arise wth future geothernal usage, 93

social implicetions that ay eries with future 
geothermal use, 125

Some aspects of property rights, 472

Sone issues regarding regulatory policy, polltical participation, and social implications of geothernal resource development in the Imperial Valley, 74 (NP21381)

Some issues regarding regulatory policy, political participation, and social implications of geothermal resource development in the Imperial Valley, 142

Susanville Geotheraal Energy Project overview, 36 (SAN1077-4)

Susanvilie project requi rements, 37 (SAN-1077-4)

Technical assessment of the Impact of geopressure development in the Corpus Christl area of Texas, 120

Toward theory of property rights, 460

Towards a responsible energy policy, 197

SOCIO-ECONOMIC FACTORS/MATHEMATICAL MODELS

Socio-economlc model, 38 (SAN-1077-4)

SOLAR AIR CONDITIONING/LEGISLATION

Research, development, and the energy crisis. Hearlngs held November $20,1973,383$

SOLAR ENERGY

Al ternative sources of energy: practical technology and phllosophy for a decentralized soclety, 213

Continuling energy crisis in America, 210

Proceedings of citizens' forum on potentlal future energy sources held at Portland, Oregon, January 17, 1974,223

SOLAR ENERGY/ECONOHIC POLICY

Alternative energy sources for the UK, 77

SOLAR ENERGY/ENVIRONMENTAL EFFECTS

Protecting the environment, 101

U.S. onergy $R$ and $D$ : policy and priorities, 294

SOLAR ENERGY/FEASIBILITY STUDIES

Other energy sources, 64 (CONF-760205-)

SOLAR ENERGY/FORECASTING

Al ternate energy sources for Hawall. Proceedings of the workshop held May 8-9, 1975, in Honolulu, Hawall 219

SOLAR ENERGY/RESEARCH PROGRAMS

Highlights of energy related leglslation in the 93rd Congress. Prepared at the request of Henry $M$ Jackson, Chairman, Comalt tee on Interior and Insular Afralrs, United States Senate pursuant to S.Res. 45 , 215

\section{SOLAR ENERGY/REVIEUS}

Ex-Assistant Adninlstrator looks back on ERDA's let year. and ahead to 2nd (Intervlew with John M. Teem, forner AA for solar, geotheral, and advanced energy systems), 60

Solar and geothermal energy: new competition for the at om, 248

SOLAR POWER PLANTS

$$
\text { Seo also ORBITAL SOLAR POWER PLANTS }
$$

SOLAR POWER PLANTS/RESEARCH PROGRATS

Research, development, and the nergy crisis. Hearing before the subcomittes on Energy of the Comittes on Science and Astronautica, U.S. House of Representatives, Ninety-Third Congress, FIrst Session, November $20,1973,272$

SOLAR SPACE HEAT ING/LEGISLATION

Research, development, and the energy crisls. Hearings held Novenber $20,1973,383$

SOLID HASTES/USES

Al ternate energy sources cor Hawall. Proceedings of the vorkshop held May 8-9, 1975, in Honolulu, Hawall,

SOUTH DAKOTA/ENERGY SOURCES

Financing infrastructure in energy development areas in the West. Proceedings of a conference held August 21 and 22,1975 , In Snowbird, Utah, 218

SOVIET UNID́N See USSR

STANDING CROP See BIOKASS

STATE GOVERMMENT

Interrelatlonship between rederal, state, and local regulatory agencies on the developnent of the geothermal resource in California, 342

Role of state government in the development of a geothernal resource, 369

Sowe lssues regarding regulatory policy, polltical participation, and social implications of geothermal resource development in the Imperial Valley, 74 (NP21381)

STATE GOVERMMENT/COOPERATION

Interrelationship between Federal, State and Local Regulatory Agencies (For exploration and exploitation of US geothermal resources), 355

STATE GOVERNHENT /GEOTHERMAL RESOURCES

state pollcies for geothermal development, 85 (NSF/RA760230 )

STATE GOVERNAENT/GOVERNMENT POLICIES

State polleles for geotheraal development, 85 (NSF/RA760230 )

STOCK RAISING HOMESTEAD ACT

Development of geothermal resources and the 1970 Geotheraal stean Act: law in search of definltion, 318 SYMPOSIA SEE REETINGS
TAX CREDITS See FINANCIAL. INCENT IVES

TAX SHELTERS

Geothermal tax considerations and shelters, 229 TAXES

See 1 :0 FINANCIAL INCENTIVES

Benefito and costs to landowners from geothermal resource lease and developaent, 140

Boom towns may hinder energy resource development, 72

Briefing on energy policy, 385

Constrainta on geothermal development: tax and beyond, 19

Continuing energy crisis in America, 210

Costs of geothermal energy development. Final report, January 1977,3

Development of geothermal laws and regulations, 302

Economic impact of geothermal energy development, 5

Energy econoulcs, 56

Energy in Oklahoma. Volume one. Final report of Oklahoma Energy Advisory Councll, February 1, 1974, 276 Energy politics of France, 78

Federal role In geothernal resource development, 18 Geothermal energy: an industry appraisal, 69

Geothermal exploration and development in the United States: tax analyais under the internal revenue code, 117

Geothermal power: strangled by red tape, 169

Geothermal tax considerations and shelters, 229

Geothermal exploration and development in the United States: tax analysis under the Internal Revenue Code, 230

Geothermal energy: an Industry appralsal, 232

Geotheraal: as we see it today, 253

Geothermal resources legal and tax considerations, 263

Geotheraal resources: legal and tax considerations, 291

Greider geothermal statement, based on testimony presented to Lt. Gov. Dymally Commlttee (Development of geothermal industry), 62

Income taxation of geothermal resources, 20

Institutional barriers to geothermal energy development. $A$ report by the Institutional Barrier Panel to the Geotherma 1 Advi sory Councl l, 135

Institutional, business, and financial aspects of the geothermal energy industry, 252

Institutional, business, and rinancial aspects of the geothermal energy Industry (abstract), 257

Internal Revenue Service Regulations (Fineral depletion allowances for tax purposes), 458

Legal aspects of geothermal energy development, 126

Legal Issues in the developwent of geopressuredgeothermal resources of Texas and Loulsiana Gulf coast, 81 ( CONF-760222-P5)

Mafority opinion in the Reich case: question of depletion, 352

Preliminary report on legal and public pollcy setting for geothermal resource development in Hawall, 279

Public opinion concerning geothermal development in Lake County, Call fornia, 65 (LBL-4447)

Recent developments in the taxation of geothermal exploration, 196

Recent developments in the taxation of geothermal exploration, 310

Recent developments in the taxation of geothermal exploration, 485

Reducling the risks in geotheraal exploration: a tax update, 180

Relch, A.E. ot al. vs Commlssioner of Internal Revenue and G.D. Rowan et al. vs Comissioner or Internal Revenue. U.S. Court of Appeals, Ninth circult. January 21, 1972 (Judiclal interpretation of IRS tax regulations relative to depletion allowance for geothermal well drilling and development; 26 CFR 1. $263(\mathrm{c}), 1.611(\mathrm{a})$, and $1.613(\mathrm{~b})), 416$

Relch, Arthur E. and Carolyn $C$. Relch ve Comalsion of Internal Revenue, U.S. Tax Court, July 31,1969 (Depletion allowances for intangible costs of drilling and developing geotheral iteam wells), 456

Relch case: economlc inplications of depletion allowances, 222

Some aspects of property rights, 472

State pollales for geothermal development, 85 (NSF/RA760230 )

structure of the geothermal industry through 1974, 238

studies in energy tax policy (Book), 208

Summary guide to the inatitutional problens confronting the geotheral energy Induatry, 244 (CONF-741145-1)

Sumary guide to the Institutional problens confronting the geotheral energy industry, 283

United States of America va. Uni on Dil Company of Callernia. U.S. District Court, N.D. California Civ. No. 72-1866 GBH. Mesorandua of Decielon, 372

victory sand and Concrete, Inc. vs Commissioner of Internal Revenue, January $2,1974,319$

TAXES/COMPARATIVE EVALUATIONS

State taxation of geothermal resources compared with atate taxation of other energy alneral s, 133

TAXES/GOVERNAENT POLICIES

Energy taxes and cubaldies, 314

Federal tax pollcy and geothermal energy development, 331

Tax treatment of exploring and developing geothermal resources, 334 
U.8. taxes on energy resources, 183

TAXES/LEGISLATION

U.8. taxes on energy resources, 183

TAXES/MANUALS

1977 guldebook to Californi taxes with special enphasi on Felationship to Federal taxes, 25

state tax handbook as of October 1, 1976, 141 TECHNDLOGY ASSESSMENT

A technology assessment of geotheral energy resource development, 184 (PB-246241)

An analysis Identifying lssues in the $f(s c a l$ year 1976 ERDA budget, 191 (PB-244863)

Economic and englneering inplications of the Project Independence 1985 geothermal energy output goal and the pendence

Federal role in geothereal resource development, 18

Federal role in geotheras resource development, encountered by the developer. An lternative energy source which is "gathering tean", is

Geothermal energy In Callfornia: tatus report, 44 (JPL$5040-25(\operatorname{Rev} \cdot A)($ APp. $)$ )

Geothermal energy, 94

Geothermal energy: legal problems of resource development, 105

Geotheral energy. Volume 1. Search period covered: 1970-1974. Citations Proa the Engineering Index Dato Base, 138

Government activity report on geothermal energy in Japan, 112

Inst I tutional barriers to geothermal energy development. A report by the Inatitutional Barrier Panel to the Geothermal Advi sory Councll, 135

Project Independence. Final task force report: geothermal energy, 250 (NP-20944)

Report to the Congress: problems in identifying developing, and using geothermal resources, 190 (NP20694)

Technlcal assessent of the Impact of geopressure development in the Corpus Chriatl area of Texas, 120

Technology forecast of United States geothermal energy resource development, 111

Uater supply: conomics, technology, and policy, 455 TECHNOLOGY TRANSFER See a I O COMMERCIALIZATION

Characteristics of nine comunities considering geothermal utilization, 39 (SAN-1077-4)

TEXAS/ENERGY POLICY

Energy development and land use in Texas. Final report on Project E/S-1: lapact on land use and value of alternative strategles for production, distribution, and utilization of energy in Texas in the period 19742000,211

Impact of state and federal law on development of geothermal resources in Texas, 299

TEXAS/ENERGY SOURCES

Energy development and land use in Texas. Final report on Project E/S-1: impact on land use and value of al ternative etrategles for production, distribution, and utilization of energy in Iexas in the period 19742000,211

Energy in Texas. Volume II. Pollcy elternatives, 281 TEXAS/GEOPRESSURED SYSTEMS

Andysis of the potential use of geothermal energy for power generation along the Texas Gulf Coast, 150 (NSFPA $-N-74-246)$

Geothermal resources of the Texas Gulf Coast: environmental concerns arlsing from the productl on and disposal of geothermal waters, 83 (CONF-760222-P5)

Impact of state and federal law on development of geothermal resources in Texes.: Project L/R-9, final report, 254 (NSF-RA-N-74-244)

Legal issues in the developaent of geopressuredgeothermal resources of Texas and Loul siana Gulf Coast 81 ( CONF-760222-P5)

Proceedings of second geopressured geothermal energy conference, Austin, Texas, February 23-25, 1976. Volume $v$. Legal, Institutional, and envi ronmental 80 (CONF-760222-PS)

Technical assessment of the lapact of geopressure development in the Corpus Christl area of Toxas, 120

TEXAS/GEOTHERMAL ENERGY

Impact of state and federal law on development of geothermal resources in Texas, 299

TEXAS/GEOTHERMAL RES OURCES

Development of geothermal energy in the Gulf Coast: soclo-economic, demographic, and polltical considerat lons, 82 (CONF-760222-P5)

Legal issues in the development of geopressuredgeothermal resources of Taxas and Loulsiana Gulf coast 81 (CONF-760222-P5)

Role of public lands in geotheral energy, 199 (CONF$750612-$ )

TEXAS/GOVERNMENT POLICIES

State polleles for geothermal development, 85 (NSF/RA760230 )

TEXAS/LAND LEASING

Role of public lands in geothermal energy, 199 (CONF750612-)

TEXAS/LAND USE

Energy development and 1 and use in Texas. Final report on Project E/S-1: lapact on land use and value of al ternative trategles for production, distribution, and utflization of energy in Texes in the period 19742000,211
TEXAS/LAWS

Impact of tate and federal law on devel opment of geotherabl resources in Texas, 299

THERMAL POWER PLANTS

See I IO GEOTHERMAL POWER PLANTS

THERMAL POWER PLANTS/FINANCING

Electrie utilities, 163 (JPL-5040-6(Vol.3))

THERMONUCLEAR REACTIONS/FEASIBILITY STUDIES

Other nergy sources, 64 ( CONF-760205-)

THERMONUCLEAR REACTIONS/REVIEUS

Ex-Assistant Administrator looks back on ERDA' 1 st year and ahead to 2nd (Interview with John M. Teen, former A for olar, oethermal, and advanced aneray systems) 60

THERMONUCLEAR REACTORS

(For use in cases where certain aspects of elther hypothetical or real thermonuclear reactors are discussed.

THERMONUCLEAR REACTORS/PLANNING

Longer-range technological potentials for energy devolopment: an essessment of the prospects in nev energy technology, 405

TIDAL POWER

Natural resources development and polleles, including envi ronmentel considerations, 437

TIDAL POWER/ECONOMIC POLICY

Alternatlve energy sources for the UK, 77

TIDAL POUER/ENUIRONHENTAL EFFECTS

Protecting the environgent, 101

TRANSALASKA PIPELINE

SEE ALASKA OIL PIPELINE

TRANSPORTATION SYSTEMS

Alternative sources of energy: practical technology and philosophy for a decentral ized soclety, 213

TRANSPORTATION SYSTEMS/FINANCING

Financing infrastructure In onergy development areas in the West. Proceedings of a conference held August 21 and 22,1975, in Snowbird, Utah, 218

UNITED KIHGDOM/ENERGY SOURCES

Al ternative onergy sources

S.D KINGDDH/ENERGY SUPPLIES

UNTED NAT IONS/GEOTHERMAL EXPLORATION

Some reflections on the history of the United Nations and U.s. Government geothermal activities, 17?

UNITED STATES OF AMERICA SEe USA

URANIUM ORES/ENERGY POLICY

Energy in soclety (Worldulde policy distribution and development), 370

URANTUM RESERVES

Indlans cautious on development, 32

US AEC/RESEARCH PROGRAMS

Proceedings of the geotheral power development conference, University of Callfornla, Berkeley, June $18,1974,271$ (LBL-3099)

US ERDA

Ex-Assiatant Administrator looks back on ERDA's 1st year. and heed to and (Interview wlth John $M$. Teen, former AA for soler, geothermal, and advanced energy systems), 60

US ERDA/BUDGETS

An enalysis Identifying Issues in the fiscal year 1976 ERDA budget, 191 (PB-244863)

An analyal identleyling lasues in the flscal year 1976 ERDA budget. Report prepared for the Comit it tee on Science and Technology. U.S. House of Representatives, Commit tee on Interlor and Insular Afralrs, U.S. Senate and the Joint Committee on Atonic Energy. NinetyFourth Congress, First Session, 209

Authorfing appropriations for the Energy Research and Development Adminlstration. Conference report to accospany H.R. 13350,106

Authorlzing appropriations for the Energy Research and Development Administration. Conference report to accompany H.R. 3474,206

ERDA authorization. Fiscal Year 1977. Part IV. Basle energy sciences. Hearings before the Subcomittee on Energy Research. Development and Demonstration of the Comant tee on Sclence and Technology, U.S. House of Representatlues, Ninety-Fourth Congress, "Second Bession, February 26, 2976, 129

ERDA a thorizetion. Ficcal Year 1977. Part III. Geothermal. Hearing before the Subcomalttee on Energy Research, Development and Demonstration of the Comit itee on Science and $T$ echnology, U.S. House of Representatives, Ninety-Fourth Congress, Second Session, February 19, 1976, 132

ERDA uthorizetion. Part II. 1976 and transition perlod: geothermal. Hearings before the Subcomit tee on Energy Research, Development, and Demonatration of the Committee on Sclence and Technology, U.S. House of Representatives, NinetyFourth Congress, First Session, 203

Nonnuclear energy research and development: liscal year 1976 authorization. Hearings before the Subcomittee on Energy Research and Water Resources of the 
Comittee on Interior and Insular Afralrs, United States Senate, Ninety-Fourth Congress, First Session on $5.598,204$

Results of an opinion survey on the 1977 budget proposal of the Energy Research and Development Administration. Printed at the request of Henry M. Jackson, Chairaen, Comittee on Interlor and Insular Afralrs, United states Senate, 86

US ERDA/DEMONSTRATION PROGRAMS

ERDA's geotheraal $R$ and $D$ program, 102

US ERDA/ENERGY POLICY

Analysis of the ERDA plan and progran (By U. S. Congress office of Technology Assessment), 205

$A$ and $D$ In generation: giving practical direction to diverse views, 145

US ERDA/LEGISLATIÓN

U.S. Energy Resources Development AdmInIstration: Geothermal Loan Guaranty Program, 228

US ERDA/LOAN GUARANTEES

U.S. Energy Resources Development Admini atration: Geothermal Loan Guaranty Progran, 228

US ERDA/PUBLIC OPINION

Results of an opinton survey on the 1977 budget proposal of the Energy Research and Developeent Adalnistration. Printed at the request of Henry M. Jackson, Chalirman, Comaltee on Interior and Insular Affairs, United States Senate, 86

US ERDA/RESEARCH PROGRAMS

An analysis identifying issues in the fIscal year 1976 ERDA budget, 191 (PB-244863)

An analysis of the ERDA plan and progran, 153 (PB-250636)

An analyais Identifying issues in the fiseal year 1976

ERDA budget. Report prepared for the Comittee on Sclence and Technology, U.S. House of Representatives. Coantee on Interior and Insular Affairs, U.S. Senate and the Joint Comittee on Atomic Energy, NinetyFourth Congress, First Session, 209

Analysis of the ERDA plan and progras (By U. S. Congress office of Technology Assessment), 205

Authorizing appropriations for the Energy Research and Developaent Adminl stration. Conference report to accompany H.R. 13350,106

Authorizing appropriations for the Energy Research and Developaent Administration. Conference report to accompany H.R. 3474, 206

Conparative analyais of the 1976 ERDA plan and progran, 95

ERDA's geothermal $R$ and D prograe, 102

ERDA a thorization. Fiseal Year 1977. Part IV Basle energy sciences. Hearings before the Subcomittee on Energy Research, Development and Demonstration of the Energy Research, Developaent and Demonstration of the Representatlves, Ninety-Fourth Congress, Second Session, February 26, 1976, 129

ERDA athorization. Part II. 1976 and tranation period: geotherwal. Hearings before the Subcomalt tee on Energy Research, Development, and Demonstration of the Comittee on Selence and Technology, U.S. House of Representatives, NinetyFourth Congress, First Session, 203

Geothermal energy resource utllization program planning, 66 (MTR-7137)

Geothermal energy development. Hearing before the Subcommittee on Energy Research and Water Resources of the Combittee on Interlor and Insular Afrairs, United States Senate, Ninety-Fourth Congress, First Session. 217

Natlonal progras definition study for the non-electrical utilization of geothermal energy, 173 (ANCR-1214)

National plan for energy research, developaent and denonstration: creating energy cholces for the future. Volume 2. Program implementation, 84 (ERDA-76-1(Vol.2)

Nonnuclear energy research and development: fiscal year 1976 athorization. Hearings before the Subconnittee on Energy Research and Heter Resources of the Comittee on Interlor and Insular Affairs, United States Senate, Ninety-Fourth Congress, First Session US FEA on S. 598, 204

FEA: prices hold key to energy future, 63

US FEA/RESEARCH PROGRAHS

Federal organization for nonnuclear energy research and development activities of departments and agencies other than ERDA: FY 1976, 175 (NP-20699) US KRC/RESEARCH PROGRAMS

Federal organization for nonnuclear energy research and development activities of departments and agencles other than ERDA: FY 1976, 175 (NP-20699)

US DRGANIZATIONS

See a 1 o ENUIRONAENTAL PROTECTION AGENCY

NASA

NATIONAL SCIENCE FOUNDATION

US AEC

US ERDA

US FEA

US ORGANIZATIONS/COOPERATION

Interrelat lonship between Federal, state and Local Regulatory Agencies (For exploration and exploltation of US geothermal resources), 355

US ORGANIZATIONS/ENERGY SOURCE DEVELOPMENT

Cooperative efforts by Industry and government to develop geothermal resources, 241 (NSF/RA/N-74-159) US ORGANIZATIONS /LAND LEASING

Leasing of Federal geothermal resources, 242 (NSF/RA/N74-159)

US ORGANIZATIONS/RESEARCH PROGRAMS

Cooperative efforts by industry and government to develop geotherwal resources, 241 (NSF/RA/N-74-159)

Role of the U.S. Geological Survey in assessing the Natlon's geotherwal energy resources, 239 (NSF/RA/N-74159)

USA

see also ALASKa

ARIZONA

CALIFORNIA

COLORADO

HAHAII
IDAHO

IOWA

LOUISIANA

MONTANA

NEUADA

NEW MEXICO

NORTH DAKOTA

OKLAHOMA

DREGON

SOUTH DAKOTA

TEXAS

UTAH

USA/ENERGY DEMAND

Luncheon Sessi on, Thursday, 10 May 1973 (National Conference on Geotheraal Energy, Pal (uprings, Calif.), 340

USA/ENERGY POLICY

Adaini stration's energy wessage and program: the need for prompt development of a national energy polley, 406

Afternoon General Session, Friday, 11 Kay 1973 (National Conference on Geothermal Energy, Palw Springs, California), 341

Dinner Sesalon, Thuraday, 10 May 1973 (National Conference on Geotheraal Energy, Pale Springs, Callfornia), 339

Energy conomics, 56

Energy policy interactions in the United States, 333

Energy self-sufficlency: how auch; how soon, 216

Energy taxes and subsidles, 314

Federal energy regulation: an organizational study, 262 (TID-26559)

Geothermal energy resources and research. Hearings before the Conmittee on Interfor and Insular Affalrs, United States Senate, pursuant to $S$. Res. 45, a netional fuels and energy policy study, Ninety-Second Congress, Second sesel on on the role of geothermal energy resources in. our nation's future energy economy, June 15 and $22,1972,407$

Luncheon Session, Thursday, 10 may 1973 (Natlonal Conference on Geothermal Energy, Palm Springs, Callf.), 340

Nation's energy future. A report to Richard M. Nixon, President of the United States, 322 (WASH-1281)

National plan for energy research, development and demongtration: creating energy cholces for the future. Volume 2. Program Implementation, 84 (ERDA-76-1(Vol.2)

President's message on supply of energy and clean alr, also fact sheet from Offlce of the Hhite House Press Secretary, 425

Profect Independence. A proposed progran for U.S. energy self-sufficiency by 1980, 275

Research, development, and the energy crisis. Hearing before the subcomittee on Energy of the Comittee on Sclence and Astronautice, U.S. House of Representatives, NInety-Third Congress, First session, Novenber 20, 1973, 272

S.1283, Nat Ional Energy Research and Development Policy Act of 1973,359

Toward a national energy policy (Agencles administering energy and attendant policy problems), 356

USA/ENERGY SHORTAGES

America's energy potential: a sumary and explanation prepared by Congressman Horris K. Udall, Chairman Subcommittee on the Environment for Use of the Comittee on Interlor and Insular Arraira of the U.S. House of Representatives, NInety-third Congress, Firat Session, Oetober 1973,386

Continuing energy crisis in America, 210

USA/ENERGY SOURCES

America's energy potential: a sumary and explanation prepared by Congressman Morris K. Udall, Chalraan. Subcomittee on the Environment for Use of the Committee on Interior and Insular Affairs of the U.S. House of Representatives, NInety-third Congress, First Session, Detober 1973, 386 Comparative analysis of the 1976 ERDA plan and progran,

Energy and the future (Book), 362

Energy outlook for the 1980\%. A study prepared for the use of the Subcomittee on Economic Progress of the Joint Economic Combittee, Ninety-Third Congress, First Session, by W. N. Peach, December 17, 1973 (Review), 388

Indians cautlous on development, 32

Introduction: the energy outlook, 377

National plan for energy research, development and demonstration: creating energy cholces for the future. Volume 2. Progran impleaentation, 84 (ERDA-76-1(Vol.2) 
Observations on Federal Energy Research and Developaent, December 1974, 71

USA/ENERGY SUPPLIES

Energy company: anopoly trend in the energy arkets, $430(P B-218830)$

USA GEOTHERMAL ENERGY

1974: the geothermal year in retrospect (Development probleas and outlook), 182

Development of the Nation's geotheraal energy resources. II, 254

Econonics of geothermal power in the United States, 449

Geothermal energy resources (Group position paper, 3 subgroup papers, and 1 review paper), 156 (CONF-750720)

Geothermal resources rescarch and technology, 245

Geothermal energy. Hearing before the subcomittee on energy of the Comittee on selence and Astronautica, United states House of Representatives, Ninety-Third Congress, Flrst Sesalon on H.R. 8628, H.R. 9658, September 11, 13, and $18,1973,379$

Potential national benefits of geotheraal electrical eneray production from hydrotheral resources in the Uest, 97

Potential for energy production from geothermal resourcese. Report of the Subcomittee on Water and Power Resources, Comittee on Interior and Insular Affelis, Ninety-Third Congreas, First session, December 1973,378

President's message on upply of energy and clean alr, also fact theet fron office of the White House Press. Secretary, $\$ 25$

USA/GEOTHERMAL EXPLORATION

Exploration and development of geothermal resources in the United States, 1968 to 1975,113

Flow chart of critical path in geothermal exploration. 343

Geothermal exploration on public lands: when and under what conditions, 337

Role of the U.S. Geological survey in assessing the Nation's goothermal energy resources, 239 (NSF/RA/N-74159)

Some replections on the history of the United Natione and U.S. Govarnment geothermal activities, 177

USA/GEOTHERMAL FIELDS

Geothermal tean leasing; hearings before Subcomittee on Minerals, Materlals and Fuels on $s, 23$ and S. 912 , March 12-22, 1970,465

USA/GEOTHERMAL POWER PLANT

flow chart of critlcal path in geotheral exploration, 343

USA/GEOTHERMAL RESOURCES

Geothermal steam Act of 1970: known geothermal resources areas; partial list, 426

Afternoon General Session, Friday, 11 May 1973 (National Conference on Geothermal Energy, Palm Springs, Callfornia), 341

Assessment of geothermal energy resources, 393

Classiflcation of public lands valuable for geothernal etean and ssoclated geotheral resources (Geothermal atean act of 1970$), 434$

Development of the Nation's geothermal energy resources, 170

Dinner Session, Thursday, 10 May 1973 (Natlonal Conference on Geothermal Energy, Palm Springs, Call itornta), 339

Geothermal exploration and development in the United states: tex analyels under the Internal revenue code, 117

Geothermal renources: potentlal energy giant, 258

Geothermal resources. Hearings before the Subcomittee on Vater and Power Resources of the Comiltee on Interior and Insular Affalrs, United States Senate, Minety-Thled Congress, first session on the potential for the production of power fron geothermal resources, 284

Geothermal energy resources and research. Hearings pursuent to $S$. Res. 45, a national fuel and energy polley tudy, on the role of geotherwal energy resources in our Nation's future energy econony, June 15 and $22,1972,402$

Role of the U.S. Geological Survey In assessing the NatIon's geothermal energy resources, 239 (NSF/RA/N-74159)

Technology forecast of United States geotheral energy resource development, 111

USA/LEGISLATION

Geothermal explorati on and development In the United statea: tax analyals under the internal revenue code, 117

Geothernal resources - operations on public, ecquired and withdrawn lands; notlce of proposed rulemaking, 346

leasing on publlc, equired and withdrawn lands: reviston of proposed rule, 347

Legal espects of geothermal energy development, 126

Packwood geothermal bill (senate B111 s. 3392), 259

Proposed rule aaking: geothermal resources - leasing on public, ecquired and withdraun lends; revision of proposed rule, 345

United states geotheraal legisiation and environmental inpact for leasing, 390

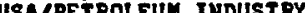

Criticel netional cholce: new energy horizons...or horizontel disintegration (Booklet), 104

USA/PUBLIC LANDS

Geothermal resources - operations on public, acquired and wthdroun lands; notlce of proposed rulenaking, 346 One third of the nation's land: report to the President and to the Congress by the Public Land Law Review Commission, 452

Proposed rule anking: geothermal resources - leasing on public, equired and ithdrawn lands; revitel on of usa propose

1977 guldebook to Callfornila taxes with special emphasis on relationshlp to Federal taxes, 25

State tax handbook as of October 1, 1976, 141

USSR/RECREAT I ONAL AREAS

Possible conflict between the interests of tourism and geotheral power development, 127

UTAH/ENERGY SOURCES

Financing Infrastructure in energy development areas in the West. Proceedings of a conference held August 21 and 22,1975 , in snowblrd, Utah, 218

UTAH/GEOTHERMAL RESOURCES

Geothermal resources. Parts I and II. Hearings before the Subcommittee on Water and Power Resources of the Comittee on Interior and Insular Affalrs, United States Senate, NInety-Third Congress, Firat Session, 297

UTAH/GOVERNMENT POLICIES

state pollcies for geothermal development, 85 (NSF/RA760230 )

UTAH/US ORGANIZATIONS

A brief outline of geothermal regulatory agencles in the vestern United States, 304

UTAH /UATER RESOURCES

Western tates water requirements for energy development to $1990,249($ NP-20555)

VENEZUELA/ENERGY POLICY

Energy policles of the world: Vinezuela (Book), 221

$$
\text { W }
$$

HAIRAKEI GEOTHERMAL FIELD/GEOTHERMAL POWER PLANTS

Environmental impact of geotheraal power plent, 188 WASHINGTON/GEOTHERMAL RESOURCES

Pacifle Northwest geothermal: review and outiook, 61

WASHINGTON/GOVERNMENT POLICIES

State polfeles for geothermal development, 65 (NSF/RA760230)

UASHINGTON/US ORGANIZATIONS

A brief outline of geothermal regulatory agencles in the western United States, 304

WASHINGTON/WATER RESOURCES

Western states vater requirements for energy developinent to 1990,249 (NP-20555)

WASTE HEAT/RECOVERY

Alternative sources of energy: practical technology and phllosophy for decentralized society, 213

VATER POLLUTION

Interstate environmental problens: a gulde to water pollution and water searcsty, 317

UATER POLLUTION ABATEMENT

Geographlcal envi ronmental analyels. FInal report, 29

Geothermal Environmental Advisory Panel. Second annual report, July $1,1975-J u n e 30,1976,136$

Geothermal resources operational (GRO) Order No. 4 for central and western regions, 168

Geothermal Environmental Advisory Panel. First annual report, June $1,1974-J u n e 30,1975,225$

Geotheral Stean Act of 1970.. Public Law 91-581 Senate Res. 368, 92st Congress, Decenber 24, 1970, 391 Interstate environmental problems: gulde to vater pollution and water ecarcity, 317

WATER REQUIREMENTS

Economfe Impact of geothermal energy development, 5 Water contilct from the viewpolnt of a regulator, 16

Western states water requl rements for energy development to 1990,249 (NP-20555)

HATER RESOURCES

Energy In Texas. Volume II. Polley alternatives, 281

Final environmental etatement for the geothermal leasing program. Volume 1,365

Final environmental tatement for the geotheral leasing progran. Volume II, 366

Geotheraal resources, 382

Hearing on the ownership of geothernal stean underlying Geysers. Geothermal Kinetics Ince, plaintiff, va Union oil Company of Callfornia, defendants, May 28, 1976, 33

Impact of etate and rederal law on development of geotheral resources in texas, 299

Inpacts of energy resources removal from faderal and Indi an lends, 282

Interatate envi ronmental problems: guide to water pollution and water searcity, 317

Legal and policy aspects of geothermal resource devel opment, 398

Dne third of the nation's land: a report to the 
President and to the Congresa by the Public Land Law Review Commission, 452

Project Independence report, 287

Report to the Congress: problems in identifying, developing, and using geothermal resources, 190 (NP20694)

Role of state government in the development of

geothermal resource, 369

S. Con. Res. 29, to express the sense of Congress that the Bureau of Reclanation should accelerate its

Investigations of geothermal resources as a potential aljor new source of water supplies for the western United States: text: statement, 424

State responses to the energy criais, 301

Water and power from geotheraal resources in california. An overview, 313

Water conflicts fron the viewpolnt of a regulator, 16

lestern states water requirements for energy development to 1990,249 (NP-20555)

WATER RESOURCES/AVAILABILITY

Water supply: economics, technology, and policy (Book), 455

WATER RESOURCES/ECONONICS Water supply: economics, technology, and polley (Book),
455

WATER RESOURCES/LEGAL ASPECTS

Water supply: economics, technology, and pollicy (Book), 455

UATER RIGHTS

Geothernal sales contracts, 21

Geothermal energy and the iaw. I. The rederal lands management progran, 224

Summary of Section XII: legal and institutional aspects, 107

Water conflicts from the vieupolnt of a regulator, 16

Water supply: economics, technology, and polley, 455

HATER RIGHTS/LEGAL ASPECTS

Interstate environmental problems: a guide to water pollutlon and water scarcity, 317

WAVE POUER/ECDNOMI

Al ternative energy sources for the UK, 77

WELL DRILLING/ENVIRONMENTAL IMPACTS

Geothermal resources operational Order No. 1 : exploratory operat Ions, 234

WELL DRILLING/LEASES

Initial exploratory well covenant. III, 477

UELL DRILLIMG/LEGAL ASPECTS

Interrelationship between lederal, state, and local regulatory agencles on the developent of the geotheraal resource in California, 342

VELL DRILLING/POOLING

Unitization for geotheraal resources: unlted we save, 17

WELL DRILLING/REGULATIONS

Geothermal resources operational Order No. 1 : exploratory operat Ions, 234

Interrelationship between rederal, state, and local regulatory ageneles on the development of the geothermal resource in California, 342

WELL. SHOOTING
SEe EXPLOSIVE STIMULATION

HIND POWER

Alternative sources of energy: practlcal technology and philosophy for a decentralized society, 213

Proceedings of citizens' forum on potential future energy sources held at Portland, Dregon, January 17, 1974,223

WIND POHER/ECONOMIC POLICY

Alternative energy sources for the UK, 77

WIND POWER/ENUIRONHENTAL. EFFECTS

Protecting the environment, 101

UIND POWER/FORECASTING

Al ternate energy sources for Hawail. Proceedings of the workshop held May 8-9, 1975, in Honolulu, Hawall, NOOD

Alternatlve sources of energy: practical technology and philosophy for a decentralized soclety, 213

WYOMING/ENERGY SOURCES

Flnancing infrastructure in energy development areas in the West. Proceedings of a conference held August 21 and 22 , i975, In Snowbird, Utah, 218

WYOMING/GEOTHERMAL RESOURCES

Geotheral resources, present and future demand for power, and legislation in the state of Hyoming, 410

WYOMING/GEOTHERMAL WELLS

Geothermal resources, present and future demand for power and leglalation in the State of Hyoming. Publle Information series 1,67 (NP-21229)

WYOMING/GOVERNMENT POLICIES State policies for geothermal development, 85 (NSF/RA-

WYOMING/LEGISLATION

Geothermal resources, present and ruture demand for power and legisiation in the state of Uyoming. Public information series 1, 67 (NP-21229)

Geothermal resources, present and future demand for power, and legislation In the state or Wyoalng, 410

UYOMING/POHER DEKAND

Geothermal resources, present and future demand for power and legislation in the state of yyoming. Public information series 1, 67 (NP-21229)

Geotheranl resources, present and future demand for power, and legislation in the state of Wyoming, 410 WYOMING/THERMAL SPRINGS

Geothermal resources, present and future denand for power and legielation in the State of Wyoming. Public information series 1,67 (NP-21229) WYONING/US ORGANIZATIONS

A brief outline of geotheral regulatory agencles in the western United States, 304

UYOMING/UATER RESOURCES

Western states water requirenents for energy development to $1990,249(\mathrm{NP}-20555)$

YELLUNSTONE NATIONAL PARK/RECREATIONAL AREAS

Possible conflict between the interests of tourism and geothermal power development, 127 


\section{REPORT NUMBER INDEX}

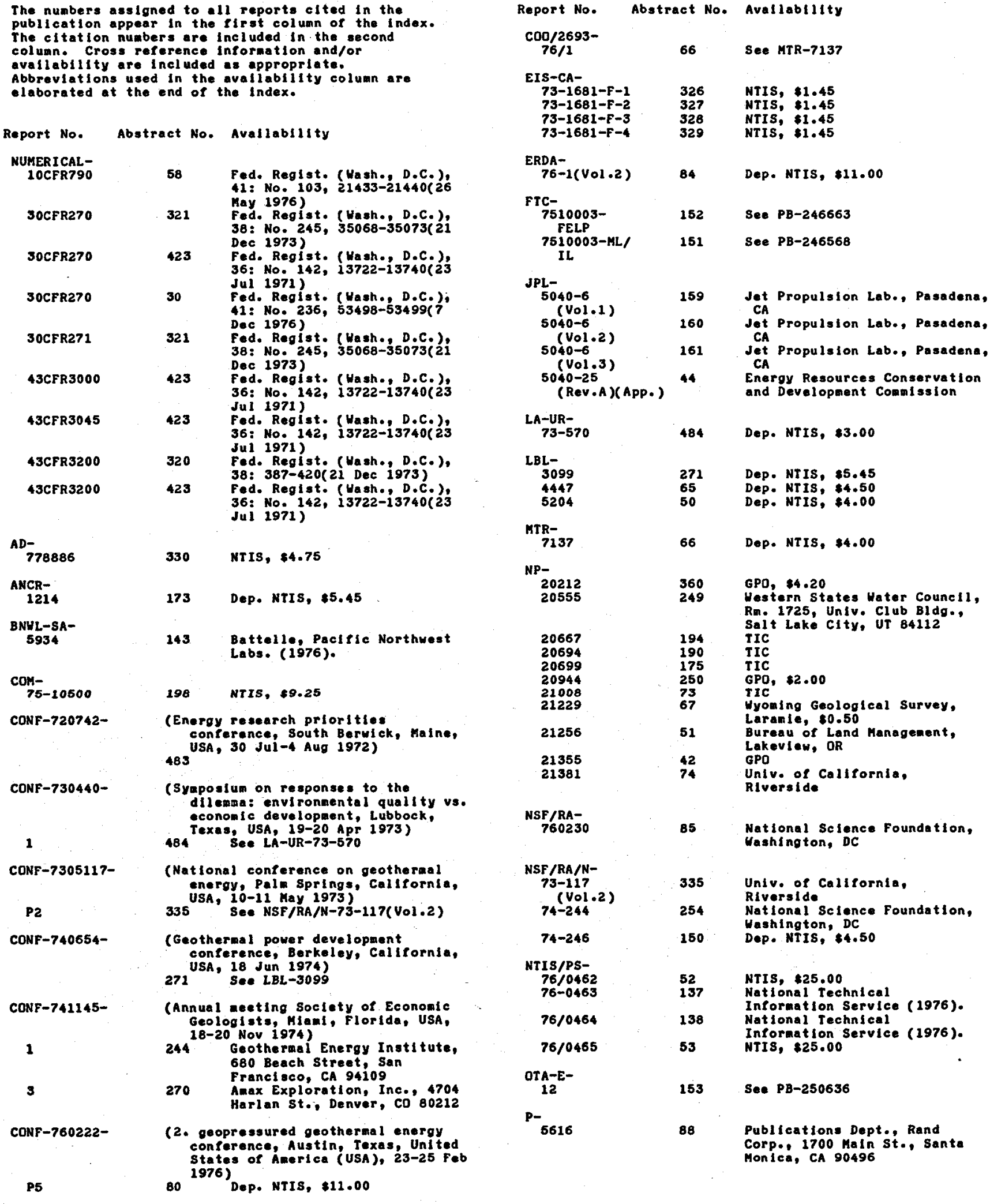


Report No.

$\mathrm{RD}-$

Report No. Abstract No. Avallability

PB-

196320
196325

196325
$203102-D$

$203102-D$
208954

208954

230248

237045

238791

$243467 / 85 T$

244863

245209

246241

246568

246663

250636

256569
453 NTIS

443 NTIS, $\$ 9.00 ; \$ 0.95$ (af)

421

396

397

361

195

195

191

315

184

151

152

153

142

NTIS, $\$ 3.00$

MTIS, $\$ 3.00$

NTIS, \$3.00: $\$ 0.95$ (mf)

NTIS, \$4.75: $\$ 1.45$ (af)

NTIS, $\$ 4.25$

NTIS, $\$ 7.00$

NTIS, $\$ 3.25$

NTIS, \$5.25

NTIS

NTIS, $\$ 13.50$

NTIS, $\$ 8.00$

NTIS, $\$ 23.75$

NTIS, $\$ 10.00$

NTIS

Abstract No, Avallabllity

73

SAN-

1077-4

TID-

3354-R1

26559

26866

27034

UCID-

16807

WASH-

1281
$1281-8$
Dep. NTIS, \$16.25

262 Dep. NTIS, \$10.75

189 Dep: NTIS, $\$ 7.00$

68 Dep. NTIS, $\$ 5.00$

186 Dep. NTIS, $\$ 4.00$

322 GPO, $\$ 1.95$

325 Dep. NTIS, \$12.75 


\section{Abbreviations Used in Availability Column}

AT Liquid Metal Fast Breeder Reactor applied technology is available to domestic requesters within the United States from the Technical Information Center, P. O. Box 62, Oak Ridge, Tennessee 37830.

Information regarding subscription purchase will be sent on request.

Foreign requesters should address inquiries to the above address.

Dep. DOE reports so designated are maintained in the organizations listed on the inside back cover.

EM Inquiries regarding the availability of blueline prints of DOE engineering drawings which were formerly available for sale by NTIS should be addressed to Technical Information Center, P. O. Box 62, Oak Ridge, Tennessee 37830 .

GJO Available from DOE Grand Junction Office, P. O. Box 2567, Grand Junction, Colorado 81501.

GPO For sale by the Superintendent of Documents, Government Printing Office, Washington, D. C. 20402.

LMEC Available only to requesters within the United States from the Liquid Metal Engineering Center, P. O. Box 1449, Canoga Park, California 91304.

NTIS For sale by the National Technical Information Service (NTIS), U. S. Department of Commerce, Springfield, Virginia 22161. Price given is the domestic price for paper copy; foreign purchasers add $\$ 2.50$ per report copy. Some recent NTIS availability statements will include pricing codes as opposed to prices. These codes are related to actual prices in the table below.

RSO Available only to requesters within the United States from the Reactor Standards Office, Oak Ridge National Laboratory, P. O. Box X, Oak Ridge, Tennessee 37830.
TIC Available from the Technical Information Center, P. O. Box 62, Oak Ridge, Tennessee 37830 .

\section{NTIS NORTH AMERICAN PRICE CODES Issue 4 \\ October 1977}

Most NTIS products and services are now announced by price codes and, therefore, without specific prices in NTIS journals, newsletters and indexes.

The current dollar equivalent for each code is shown in the schedule below. Orders must list the accession number(s) and be accompanied by the total dollar amount from the current schedule.

ISSUE 4 prices will be valid through March 31, 1978. After that date, source clients who have not received the latest schedule may contact the Input Branch, 703-557-1690 for the next issue.

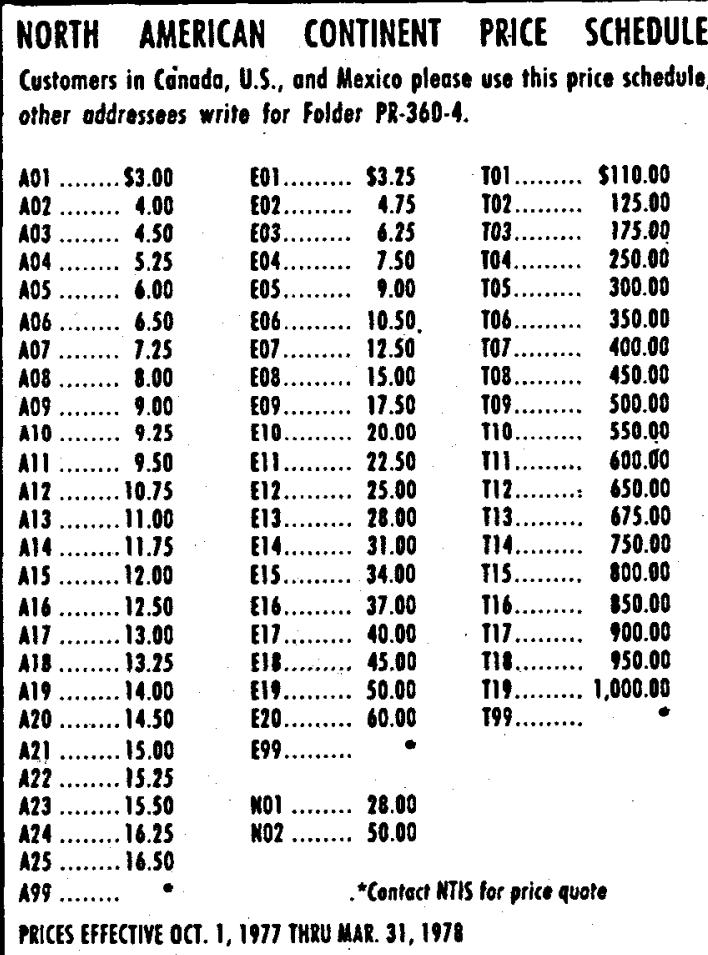

U.S. DEPARTMENT OF COMMERCE National Technical Information Servlce 5285 Port Royal Road Springfield, Virginia 22161 